
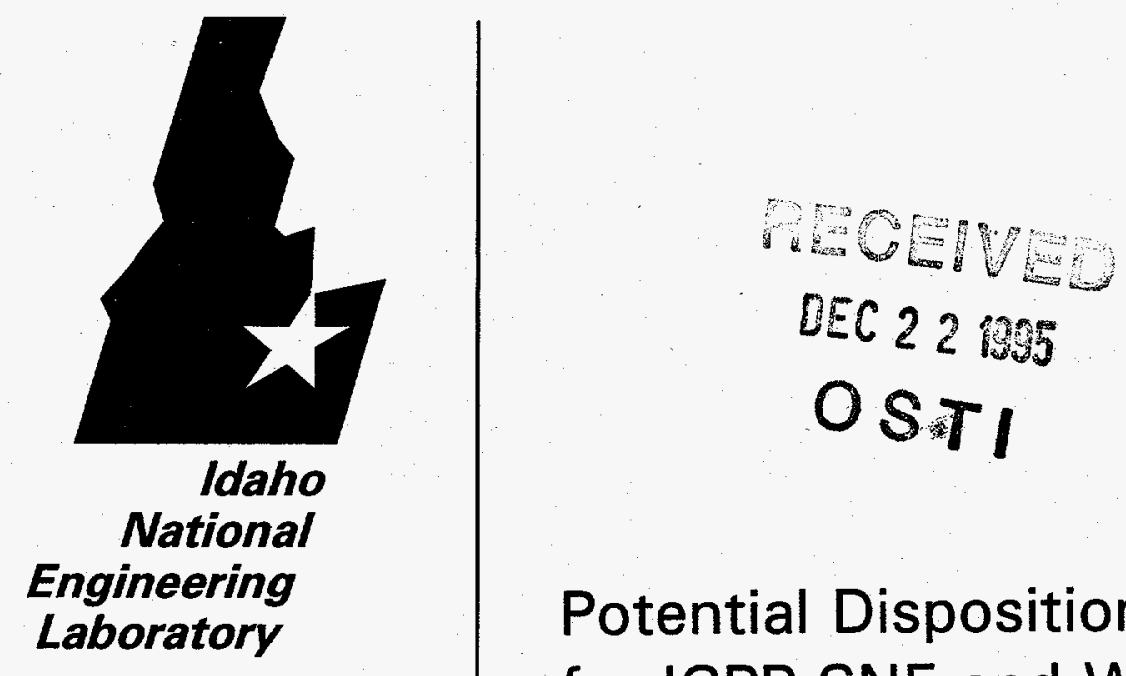

November 1995

DEC 221985

OSTI

Potential Dispositioning Flowsheets for ICPP SNF and Wastes

Edited by: A. L. Olson

Contributors:

P. A. Anderson D. A. Knecht

$\begin{array}{ll}\text { C. L. Bendixsen } & \text { D. K. Kubosumi }\end{array}$

R. D. Boardman J. D. Law

J. D. Christian

D. W. Marshall

T. M. Gnose

L. O. Nelson

R. S. Herbst

D. D. Siemer

G. F. Kessinger

T. R. Thomas

R. J. Kirkham

P. A. Tullock

三Llockheed 


\section{DISCLAIMER}

This report was prepared as an account of work sponsored by an agency of the United States Government. Neither the United States Government nor any agency thereof, nor any of their employees, makes any warranty, express or implied, or assumes any legal liability or responsibility for the accuracy, completeness, or usefulness of any information, apparatus, product, or process disclosed, or represents that its use would not infringe privately owned rights. Reference herein to any specific commercial product, process, or service by trade name, trademark, manufacturer, or otherwise does not necessarily constitute or imply its endorsement, recommendation, or favoring by the United States Government or any agency thereof. The views and opinions of authors expressed herein do not necessarily state or reflect those of the United States Government or any agency thereof. 


\section{DISCLAIMER}

Portions of this document may be illegible in electronic image products. Images are produced from the best available original document. 


\title{
Potential Dispositioning Flowsheets for ICPP SNF and Wastes
}

\author{
Edited by: A. L. Olson
}

Contributors:
P. A. Anderson
D. A. Knecht
C. L. Bendixsen
D. K. Kubosumi
R. D. Boardman
J. D. Law
J. D. Christian
D. W. Marshall
T. M. Gnose
L. O. Nelson
R. S. Herbst
D. D. Siemer
G. F. Kessinger
T. R. Thomas
R. J. Kirkham
P. A. Tullock

Published November 1995

Idaho National Engineering Laboratory

Nuclear Engineering Department

Lockheed-Martin Idaho Technologies Company

Idaho Falls, Idaho 83415

Prepared for the

U.S. Department of Energy

Assistant Secretary for Environmental Management

Under DOE Idaho Operations Office

Contract DE-AC07-94ID13223

DISTAIBUTION OF THIS DOCURART is

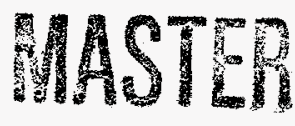




\section{EXECUTIVE SUMMARY}

The Idaho Chemical Processing Plant (ICPP), located at the Idaho National Engineering Laboratory (INEL), has reprocessed irradiated nuclear fuels for the U. S. Department of Energy (DOE) since 1953. This activity resulted mainly in the recovery of uranium and the management of the resulting wastes. The acidic radioactive high-level liquid waste was routinely stored in stainless steel tanks and then calcined to form a dry granular solid. The calcine is stored in stainless steel bins that are housed in underground concrete vaults. In April 1992, the DOE discontinued the practice of reprocessing irradiated nuclear fuels. This decision has left a legacy of 1.8 million gallons of radioactive liquid wastes ( 1.5 million gallons of radioactive sodiumbearing liquid wastes and 0.3 million gallons of high-level liquid waste), 3800 cubic meters of calcine waste, and 289 metric tons of heavy metal within unprocessed spent nuclear fuel (SNF) left in inventory at the ICPP.

The nation's radioactive waste policy has been established by the Nuclear Waste Policy Act (NWPA), which requires the final disposal of SNF and radioactive waste in accordance with U.S. Environmental Protection Agency (EPA) and Nuclear Regulatory Commission (NRC) standards. In accordance with these regulations and other legal agreements between the State of Idaho and the DOE, the DOE must, among other requirements, 1) complete a final Environmental Impact Statement by April 30, 1995, 2) evaluate and test sodium-bearing waste pre-treatment technologies, 3) select the sodium-bearing and calcine waste pre-treatment technology, if necessary, by June 1, 1995, and 4) select a technology for converting calcined waste into an appropriate disposal form by June 1, 1995.

The primary objective of the ICPP Waste Management Technology Development Program is to develop and implement safe, cost-effective, and environmentally responsible methods for the conditioning, interim storage, qualification, and final disposition of SNF and radioactive wastes. This study, as part of the Technology Development Program, identifies technologies and combinations of technologies linked together to form options for disposal of SNF, calcine waste, and radioactive liquid waste.

Two basic disposal options are available. One is to dispose of the material with as little pretreatment as possible. The second is to separate those components which are radioactive, and require isolation from those which are inert, thereby minimizing the volume of material which requires isolation in a permanent repository. Assumptions made in developing disposal alternatives include: 1) treatment and immobilization processes should accommodate SNF, radioactive liquid and calcine wastes, 2) existing facilities will be utilized to the extent practical, 3 ) actinides and fission products will be collected into a high-level waste (HLW) stream for disposition approaches involving constituent separation, 4) low-level waste (LLW) will meet NRC Class C, or lower, limits.

Conceptual process flow diagrams and mass balances have been developed and described in this study for more than a dozen SNF and waste disposal options. There are advantages and disadvantages associated with each option. Evaluation of each of these disposal alternatives against specific criteria, such as life-cycle cost, volumes of final immobilized waste, and safety, are beyond the scope of this work. However, the information provided within this document forms the technical basis with which to perform such an evaluation. 


\section{TABLE OF CONTENTS}

Executive Summary

$\underline{\text { Page }}$

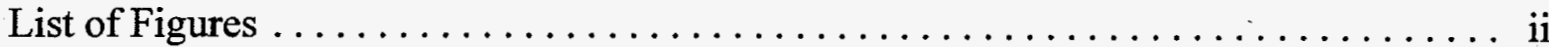

List of Tables $\ldots \ldots \ldots \ldots \ldots \ldots \ldots \ldots \ldots \ldots \ldots \ldots \ldots \ldots \ldots \ldots \ldots \ldots \ldots \ldots$

Acronyms $\ldots \ldots \ldots \ldots \ldots \ldots \ldots \ldots \ldots \ldots \ldots \ldots \ldots \ldots \ldots \ldots \ldots \ldots \ldots \ldots$

1.0 Introduction $\ldots \ldots \ldots \ldots \ldots \ldots \ldots \ldots \ldots \ldots \ldots \ldots \ldots \ldots \ldots \ldots \ldots \ldots$

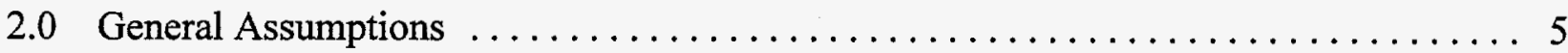

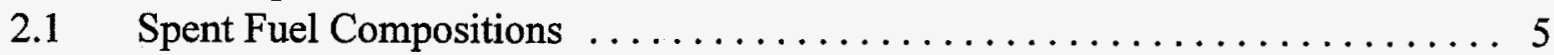

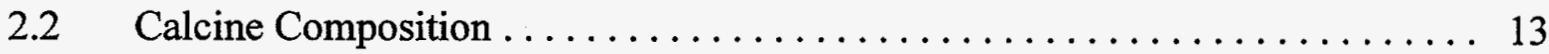

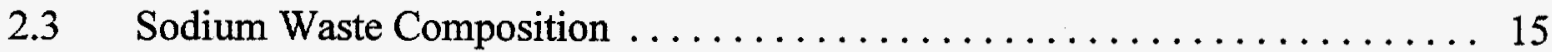

$2.4 \quad$ Low-Level Waste Classifications $\ldots \ldots \ldots \ldots \ldots \ldots \ldots \ldots \ldots \ldots \ldots$

3.0 Unit Operations and Technologies used in building waste disposal

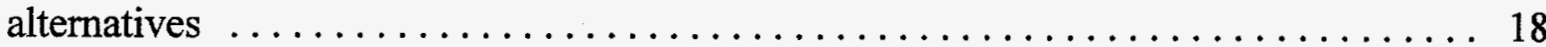

4.0 Direct Disposal Options $\ldots \ldots \ldots \ldots \ldots \ldots \ldots \ldots \ldots \ldots \ldots \ldots \ldots \ldots \ldots \ldots \ldots$

4.1 Use of High-Integrity Canisters $\ldots \ldots \ldots \ldots \ldots \ldots \ldots \ldots \ldots \ldots \ldots \ldots \ldots$

$4.2 \quad$ Pre-Conditioning Processing Options $\ldots \ldots \ldots \ldots \ldots \ldots \ldots \ldots \ldots \ldots \ldots$

4.3 Grout Encapsulation and Greater Confinement Disposal . . . . . . . . . . . 66

5.0 Segregation/Separation Processing Options $\ldots \ldots \ldots \ldots \ldots \ldots \ldots \ldots \ldots \ldots \ldots \ldots \ldots$

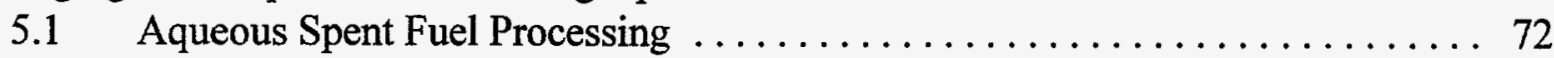

5.2 Pyrochemical Spent Fuel Processing $\ldots \ldots \ldots \ldots \ldots \ldots \ldots \ldots \ldots$

5.3 Pyrochemical Processing of Calcine $\ldots \ldots \ldots \ldots \ldots \ldots \ldots \ldots \ldots \ldots \ldots$

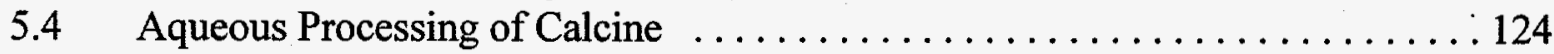

5.5 Processing of Sodium-Bearing Liquid Waste $\ldots \ldots \ldots \ldots \ldots \ldots \ldots \ldots$

5.5.1 Calcination Utilizing Chemical Additives . . . . . . . . . . . 128

5.5.2 Sodium Nitrate Removal Utilizing Freeze Crystallization . . . . . . 131

5.5.3 Radionuclide Removal Utilizing Neutralization and

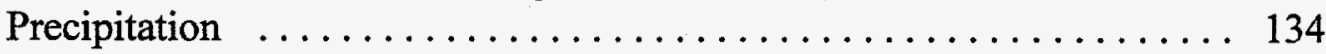

5.5.4 Radionuclide Removal by Solvent Extraction and Ion

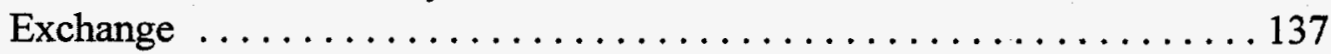

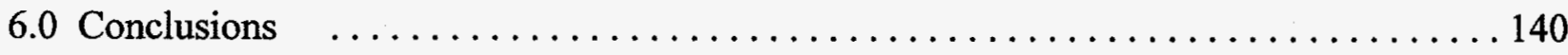




\section{FIGURES}

Figure 1 Global Dispositioning Options for SNF and Waste $\ldots \ldots \ldots \ldots \ldots \ldots \ldots$

Figure 2 Simplified Overall Process Dispositioning Options $\ldots \ldots \ldots \ldots \ldots \ldots \ldots$

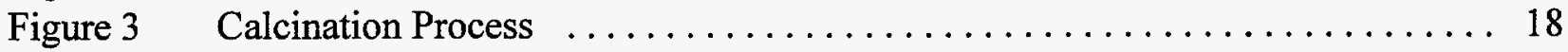

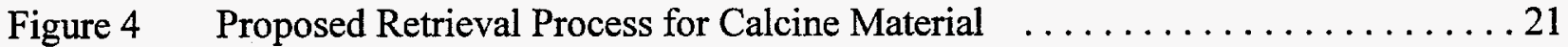

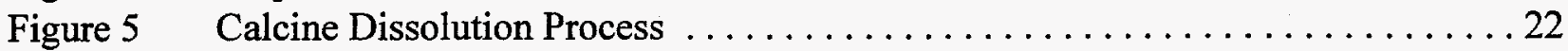

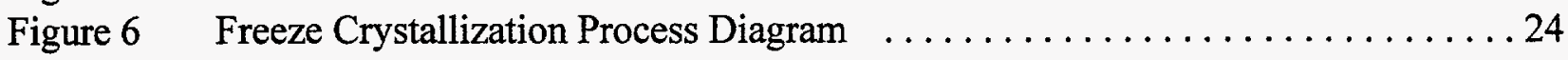

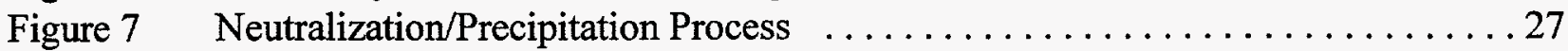

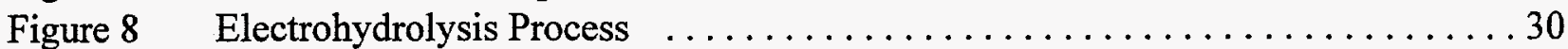

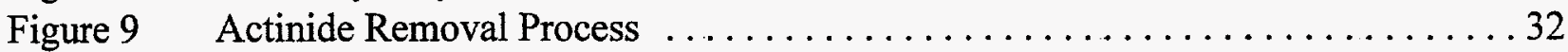

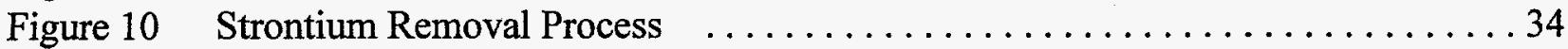

Figure 11 Process for Cs Removal by Fixed Bed Sorption $\ldots \ldots \ldots \ldots \ldots \ldots \ldots \ldots$

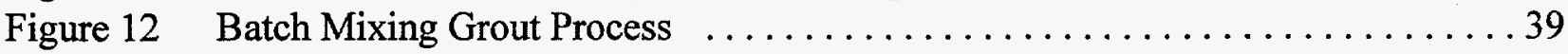

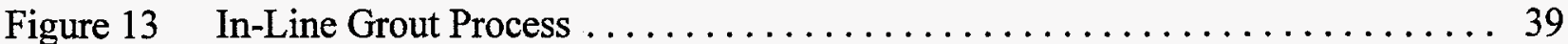

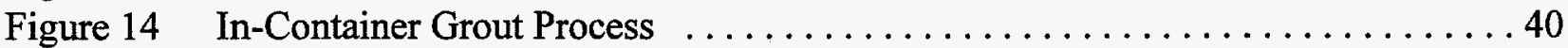

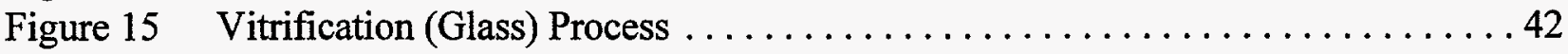

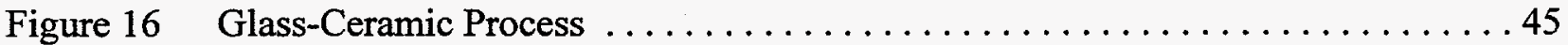

Figure 17 Direct Disposal Using High Integrity Canisters $\ldots \ldots \ldots \ldots \ldots \ldots \ldots \ldots \ldots$

Figure 18 Encapsulation of Shredded Fuel with Glass Vitrification $\ldots \ldots \ldots \ldots \ldots \ldots 54$

Figure 19 Encapsulation of Shredded Fuel and Glass Vitrification of Calcine . . . . . . . 56

Figure 20 Process Description of Encapsulation of Shredded Fuel and Glass

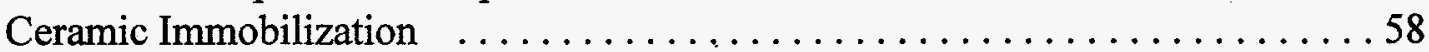

Figure 21 Proposed Grout Encapsulation and Greater Confinement Disposal Process . . . 69

Figure 22 Spent Fuel Dispositioning Aqueous Processing Alternative

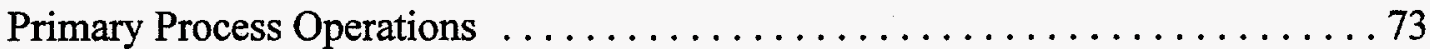

Figure 23 ICPP/INEL Spent Nuclear Fuel Dispositioning Aqueous

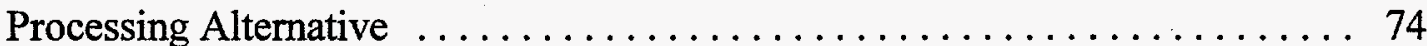

Figure 24 Molten Salt Spent Fuel Decladding ........................... 76

Figure 25 Electrolytic Molten Salt Decladding $\ldots \ldots \ldots \ldots \ldots \ldots \ldots \ldots \ldots \ldots 77$

Figure 26 Spent Fuel Dispositioning Halide Oxidation Decladding (HALOX) . . . . . . . 79

Figure 27 Zr Fuels Three-Cycle PUREX Flow Schematic Using Centrifugal Contactors . . . 81

Figure 28 Typical TRUEX Flow Schematic Using Centrifugal Contactors . . . . . . . . 83

Figure 29 Proposed Pyrochemical Processing of SNF ................... 90

Figure 30 TRUEX Separation of TRUs from Fission Products $\ldots \ldots \ldots \ldots \ldots \ldots \ldots . . \ldots 9$

Figure 31 Proposed Pyrochemical Processing AL/SNF $\ldots \ldots \ldots \ldots \ldots \ldots \ldots \ldots \ldots \ldots \ldots \ldots$

Figure 32 Proposed Pyrochemical Processing of Stainless Steel Fuels . . . . . . . . . . . 104

Figure 33 Pyrochemical Separation Process for Alumina and Sodium Calcine . . . . . . . 112

Figure 34 Pyrochemical Separation Process for Zirconia and Zirconia-Sodium Calcine . . . 113

Figure 35 Aqueous Separations Flowsheet ........................ 125

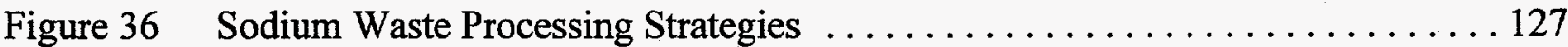

Figure 37 Baseline Sodium Waste Processing Flowsheet ................... 129

Figure 38 Flowsheet for Sodium Waste Processing using Freeze Crystallization . . . . . . 132

Figure 39 Sodium Waste Processing Flowsheet Utilizing Neutralization and

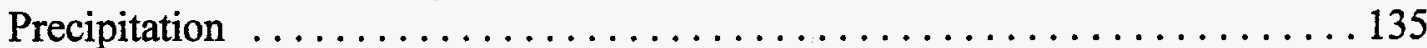

Figure 40 Sodium Waste Processing Flowsheet Utilizing Radionuclide Separations . . . 138 


\section{TABLES}

Table 1 Zircaloy Spent Fuel Composition per $100 \mathrm{Kg}$ Total Fuel Mass $\ldots \ldots \ldots \ldots$

Table 2 ATR Aluminum Fuel Composition per $100 \mathrm{Kg}$ Total Fuel Mass ......... 7

Table 3 Representative SS Fuel Composition $\ldots \ldots \ldots \ldots \ldots \ldots \ldots \ldots \ldots \ldots$

Table 4 Graphite Fuel Composition $\ldots \ldots \ldots \ldots \ldots \ldots \ldots \ldots \ldots \ldots \ldots$

Table $5 \quad$ PWR-Fuel Assembly Constituents at BOL $\ldots \ldots \ldots \ldots \ldots \ldots \ldots \ldots \ldots \ldots$

Table $6 \quad$ FP Content $\left(\mathrm{g}, \mathrm{Ci}\right.$, watt) ${ }^{\mathrm{a}}$ of 10 -yr Cooled PWR Fuel . . . . . . . . . . . . 12

Table 7 TRU Content $(\mathrm{g}, \mathrm{Ci}$, watt) of 10 -yr Cooled PWR Fuel $\ldots \ldots \ldots \ldots \ldots \ldots \ldots$

Table $8 \quad$ EOL Composition of 10 -yr Cooled PWR Fuel $\ldots \ldots \ldots \ldots \ldots \ldots \ldots \ldots \ldots$

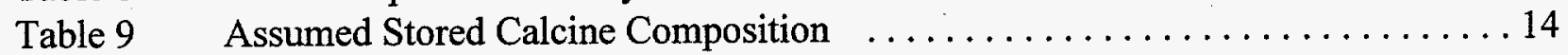

Table 10 Chemical Composition of Sodium-Bearing Waste $\ldots \ldots \ldots \ldots \ldots \ldots \ldots \ldots$

Table 11 Radiochemical Composition of Sodium-Bearing Waste $\ldots \ldots \ldots \ldots \ldots \ldots$

Table $12 \quad$ LLW Concentration Limits $\ldots \ldots \ldots \ldots \ldots \ldots \ldots \ldots \ldots \ldots \ldots \ldots \ldots \ldots$

Table 13 Precipitation Removal Percentages . . . . . . . . . . . . . . . . . . 29

Table 14 Reference Grout Formula . . . . . . . . . . . . . . . . . . . . 41

Table 15 Encapsulation of Shredded Fuel with Glass and Calcine

Vitrification, $0.7 \mathrm{~kg} \mathrm{U-235}$ Limit . . . . . . . . . . . . . . . 59

Table $16 \quad \begin{aligned} & \text { Encapsulation of Shredded Fuel with Glass and Calcine } \\ & \text { Vitrification, } 10 \mathrm{kd} U-235 \text { Limit } \ldots \ldots \ldots \ldots \ldots \ldots \ldots \ldots \ldots\end{aligned}$

Table 17 Encapsulation of Shredded Fuel with Glass and Calcine

Vitrification, $0.7 \mathrm{~kg}$ U-235 Limit . . . . . . . . . . . . . . . 61

Table 18 Encapsulation of Shredded Fuel with Glass and Calcine

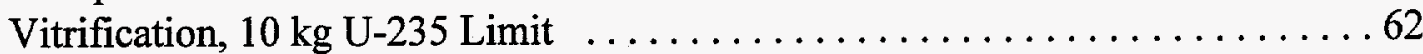

Table 19 Encapsulation of Shredded Fuel with Glass and Glass-Ceramic

Immobilization of Calcine, $0.7 \mathrm{~kg} \mathrm{U}-235$ Limit $\ldots \ldots \ldots \ldots \ldots \ldots$

Table 20 Encapsulation of Shredded Fuel with Glass and Glass-Ceramic

Immobilization of Calcine, $10 \mathrm{~kg} \mathrm{U}-235$ Limit $\ldots \ldots \ldots \ldots \ldots \ldots \ldots$

Table 21 Direct Disposal Summary $\ldots \ldots \ldots \ldots \ldots \ldots \ldots \ldots \ldots \ldots \ldots \ldots \ldots \ldots \ldots$

Table 22 Technology Status and Development Issues $\ldots \ldots \ldots \ldots \ldots \ldots \ldots$

Table 23 Mass Balance Data for Greater Confinement Alternative . . . . . . . . . . 68

Table 24 Comparison of Waste Volumes Resulting from the Spent Fuel

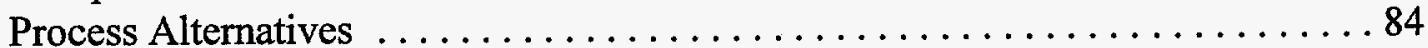

Table 25 Relative Comparison of Aqueous Process Alternatives . . . . . . . . . 85

Table 26 Mass Balance for Pyrochemical Processing of Zircaloy Fuels . . . . . . . . 91

Table 27 Fraction of Chlorides which Pass Through the Scrubber . . . . . . . . . . . 94

Table 28 Mass Ratios of FP-Cl and TRU-Cl to $\mathrm{ZrCl}_{4}$ in the Condenser . . . . . . . 95

Table 29 Fraction of Chlorides Which Pass Through Scrubber . . . . . . . . . . 102

Table 30 Mass Balance for Alumina Calcine . . . . . . . . . . . . . . . . 114

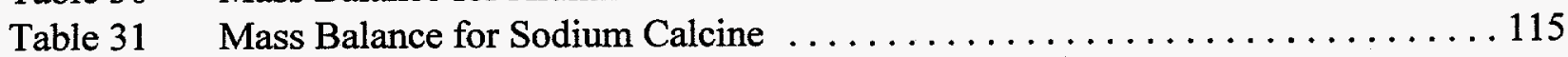

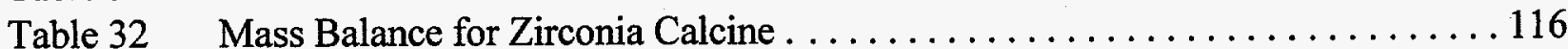

Table 33 Mass Balance for Zirconia-Sodium Calcine $\ldots \ldots \ldots \ldots \ldots \ldots \ldots \ldots 117$ 
Table 34 Assumed Chlorination Reactions and Yields $\ldots \ldots \ldots \ldots \ldots \ldots \ldots \ldots$

Table 35 Development Issues Associated with the Pyrochemical Process . . . . . . . . 123

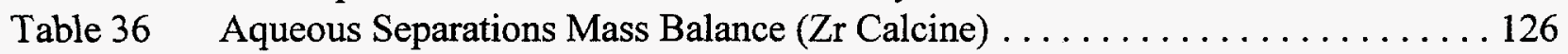

Table 37 Mass Balance for Baseline Calcination of SBW . . . . . . . . . . . . 130

Table 38 Mass Balance for Sodium Nitrate Removal Utilizing

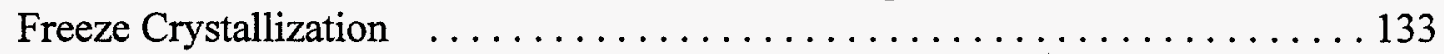

Table 39 Mass Balance for Sodium Waste Processing Utilizing

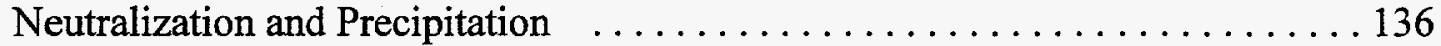

Table 40 Mass Balance for Sodium Waste Processing Utilizing Radionuclide Separations 


\section{ACRONYMS}

$\begin{array}{llll}\text { APS } & \text { - atmospheric protection system } & \text { ICPP } & \text { - Idaho Chemical Processing Plant } \\ \text { ATR } & \text { - Advanced Test Reactor } & \text { IFR } & \text { - Integral Fast Reactor } \\ \text { BDAT } & \text { - best demonstrated available } & \text { IHM } & \text { - initial heavy metal } \\ & \text { technology } & \text { INEL } & \text { - Idaho National Engineering } \\ & & & \text { Laboratory } \\ \text { BOL } & \text { - beginning of life } & \text { LAW } & \text { - low activity wastes } \\ \text { BWR } & \text { - boiling water reactor } & \text { LLNL } & \text { - Lawrence Livermore National } \\ \text { CORS } & \text { - continuous oxide reduction } & & \text { Laboratory } \\ & \text { system } & & \\ \text { CSSF } & \text { - Calcine Solids Storage Facility } & \text { LLW } & \text { - low-level waste } \\ \text { DOE } & \text { - U.S. Department of Energy } & \text { LMFBR } & \text { - Liquid Metal Fast Breader } \\ \text { EBS } & \text { - engineered barrier system } & & \text { Reactor } \\ \text { EH } & \text { - eletrohydrolysis } & & \\ \text { EOL } & \text { - end of life } & \text { LWR } & \text { - Light Water Reactor } \\ \text { FC } & \text { - freeze crystallization } & \text { MPC } & \text { - multiple purpose canister } \\ \text { FDP } & \text { - Fluorinel Dissolution Facility } & \text { MT } & \text { - metric tons } \\ \text { FHU } & \text { - fuel handling unit } & \text { MTIHM - metric ton of initial heavy metal } \\ \text { FPF } & \text { - Fuel Processing Facility } & \text { NRC } & \text { - Nuclear Regulatory Commission } \\ \text { FP } & \text { - fission product } & \text { NWCF } & \text { - New Waste Calcining Facility } \\ \text { FSV } & \text { - Fort St. Vrain } & \text { PUREX } & \text { - plutonium uranium extraction } \\ \text { GTM } & \text { - generic TRUEX model } & \text { PWR } & \text { - pressurized waster reactor } \\ \text { HALOX } & \text { - halide oxidation and dissolution } & \text { SBW } & \text { - sodium bearing waste } \\ \text { HAW } & \text { - high activity wastes } & \text { SREX } & \text { - strontium extraction } \\ \text { HEU } & \text { - highly enriched uranium } & \text { TRU } & \text { - transuranic } \\ \text { HIP } & \text { - hot isostatic press } & \text { TRUEX - transuranic extraction } \\ \text { HLW } & \text { - high-level waste } & \text { UDS } & \text { - undissolved solids } \\ \text { HTGR } & \text { - High-Temperature Gas-Cooled } & \text { WIF } & \text { - Waste Immobilization Facility } \\ & \text { Reactor } & & \\ & & & \end{array}$




\subsection{Introduction}

The Idaho National Engineering Laboratory (INEL) has operated nuclear facilities to support United States national interests for several decades. Since 1953, the Idaho Chemical Processing Plant (ICPP) has been involved with the development of technologies for the storing and reprocessing of spent nuclear fuel (SNF) and the resultant wastes. Since the advent of nuclear reactors for weapons and power production, the management of spent reactor fuel has included chemical processing. For most spent nuclear fuels, the primary purpose for processing has been to recover various heavy metals and fission products for either strategic or commercial value. During the same period, management of SNF wastes has changed from a relatively simple concern with chemical processing to a primary requirement for safe dispositioning of spent nuclear fuels. Thus, although the value of heavy metals and fission products in spent nuclear fuels has decreased dramatically in recent years, the need for nuclear waste management has not. Because of the present low-value for highly-enriched uranium (HEU), some have concluded that SNF may be stored or disposed of at essentially permanent geologic sites. However, the safety of such HEU disposal and the placement of valuable strategic material in an irretrievable location has been seriously questioned.

Chemical processing has the advantage of decades of technological development and operational experience, yet the same experience has shown that chemical processing can be unacceptably complicated and costly. For these latter reasons, and for other nontechnical and political reasons, the DOE has ordered the cessation of spent fuel reprocessing of defense related spent fuels for purposes of uranium recovery. Despite the end of SNF reprocessing, fuel and waste that still remains must be safely managed and dispositioned.

The decision by DOE to discontinue reprocessing of SNF has left nearly 768 metric tons (MT) of SNF in storage at the INEL with unspecified plans for future dispositioning. Additionally, approximately 1.5 million gallons of sodium-bearing, radioactive liquid waste and $3800 \mathrm{~m}^{3}$ of calcine (high-level waste) (HLW) are currently stored at the ICPP as a result of past reprocessing. These amounts of stored waste, along with increased environmental awareness within the DOE and among its contractors and stakeholders, mandate operation of current and future facilities in an environmentally responsible manner. A satisfactory resolution of waste disposal issues resulting from past activities is therefore required.

The primary purpose of this report is to present process flowsheets to address the processing and disposal of ICPP SNF and wastes. Figure 1-1 depicts the dispositioning options which appear to be available at this time.

It is not practical to perform a thorough investigation of each of the individual paths. Rather, a few of the more feasible options which could achieve the disposition goal and offer some probability of success will be identified. These potential disposal options will be based on sound engineering judgement and collective scientific expertise. Developmental plans and future efforts will then be focussed on these several disposal options, which are shown in Figure 1-2. 
ICPP fuel processing methods and technology have been reviewed and evaluated for their future potential. Historical methods have been updated and new processes added to increase the overall waste management potential. The processes described in this report are a mixture of established technology and new processes, thus offering the potential to improve process capabilities, reduce waste volumes, simplify equipment and facilities, and decrease facility and operating costs.

Preliminary discussions indicate that the alternative flowsheets with the greatest probability for success will consist of direct disposal of spent fuel and calcine (including some pretreatment), non-aqueous pyrochemical separations, and aqueous separations. These flowsheets consist of linking identified technologies and calculation of the mass balances, and making assumptions where there were data deficiencies exist. The results of these calculations provide the basis for making comparisons, noting where data deficiencies are, and providing a focus for developmental efforts. A more detailed developmental program plan can then be generated from these results. 


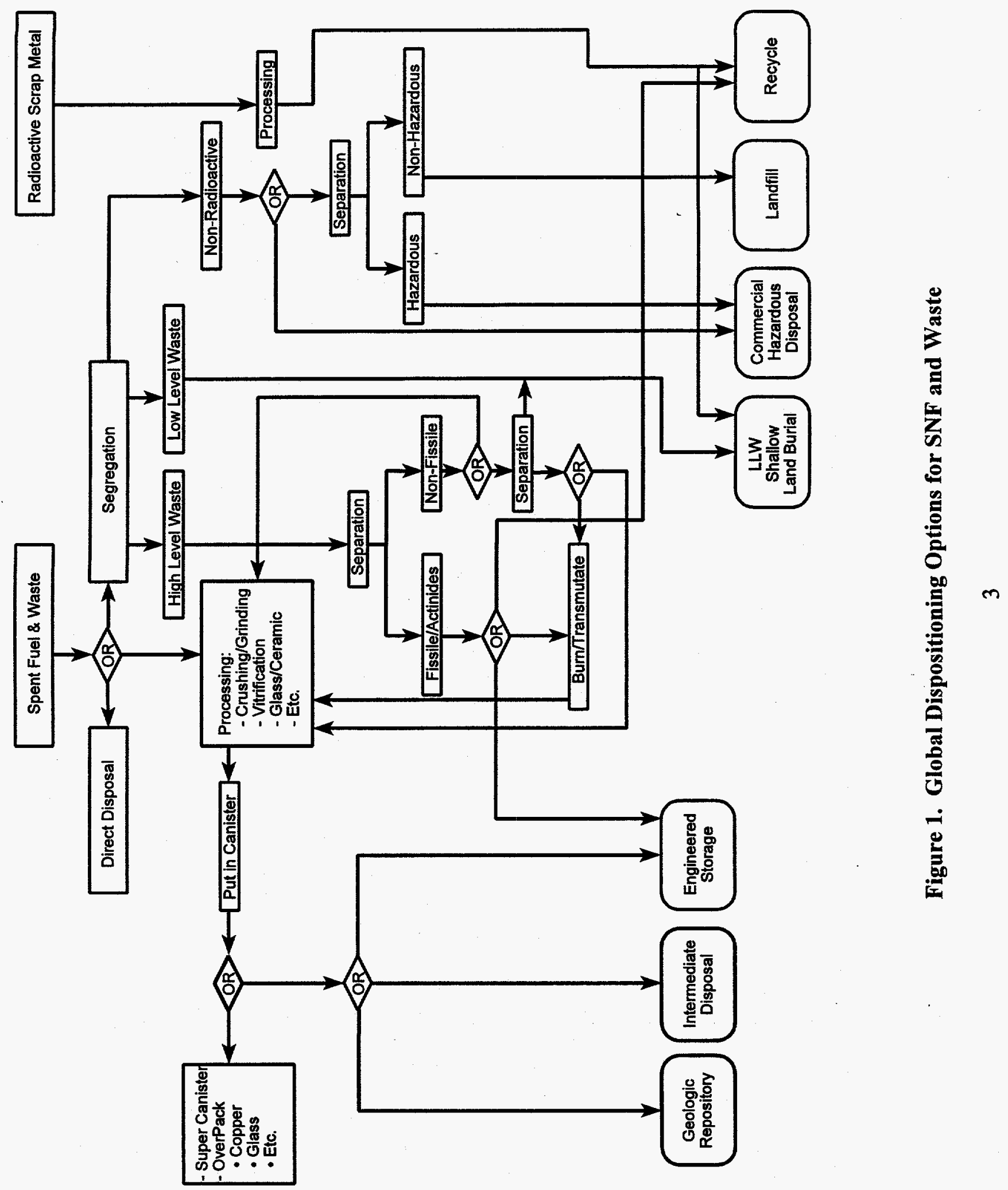




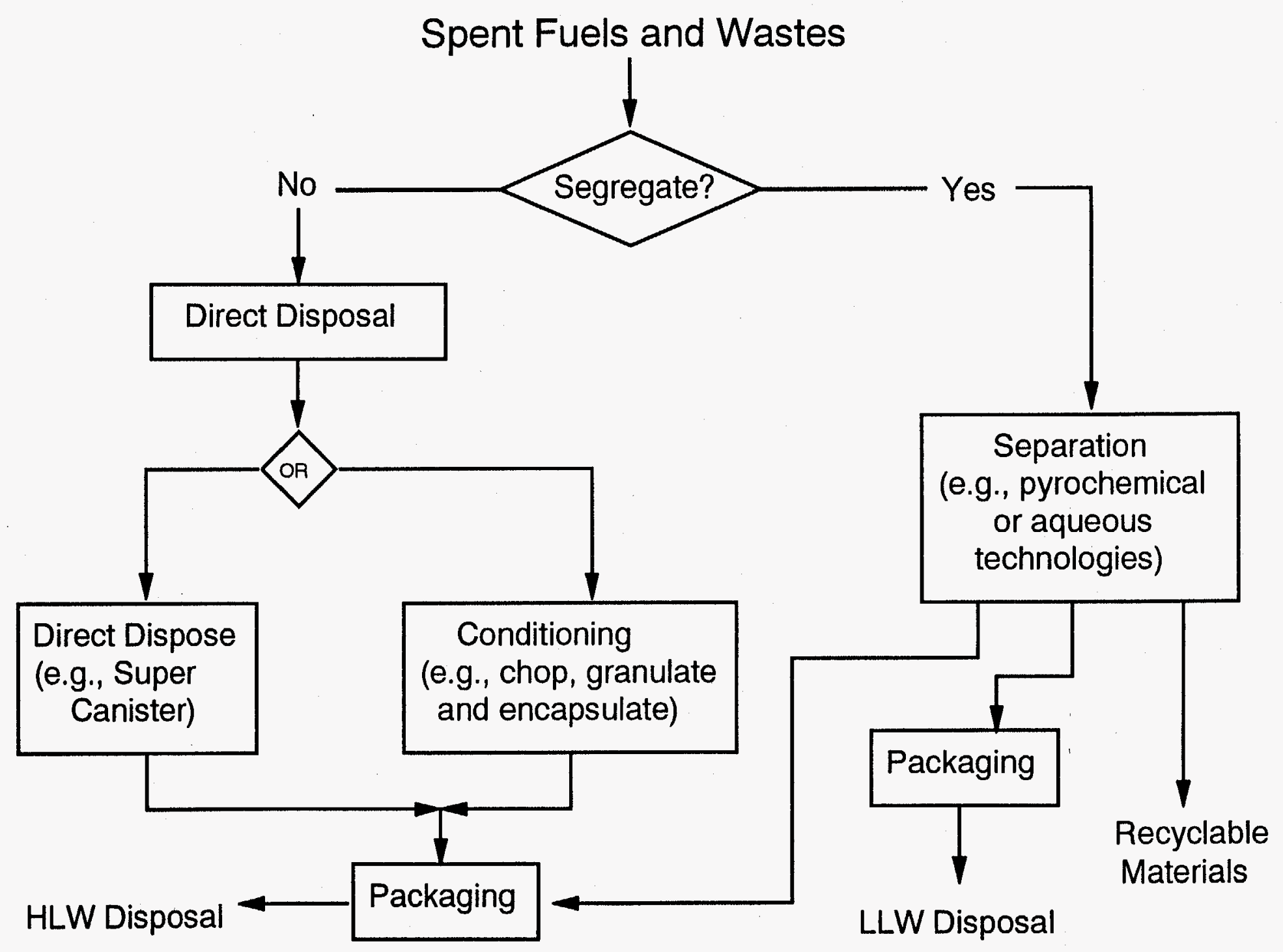

Figure 2. Simplified Overall Process Dispositioning Options 


\subsection{General Assumptions}

- That five general spent fuel types classified by cladding material, will be considered: Aluminum, Stainless Steel, Naval Zircaloy, Graphite, and Commercial.

- That there will be utilization of existing facilities to the fullest extent that is practical.

- That separations flowsheets for fission products and toxic metals will be concentrated into a high-level waste stream.

- That low-level waste will at least meet Nuclear Regulatory Commission (NRC) Class C limits.

- That there will be singular waste forms for HLW and LLW (Glass-ceramic, glass, grout).

\subsection{Spent Fuel Compositions}

Representative SNF compositions for which flowsheets have been developed are: Zircaloy, Aluminum Advanced Test Reactor (ATR), EBR-II stainless steel, and High-Temperature GasCooled Reactor (HTGR) graphite fuels. Also, commercial Light Water Reactor (LWR) oxide fuels are considered, because they represent some DOE-owned fuels. In addition, if an advanced technology can also address commercial fuel management and disposition issues, then potential applications will be expanded and added benefit may be realized from the development program.

\section{Zircaloy Fuel Composition}

The characteristic composition of spent Zircaloy fuel of typical $235 \mathrm{U}$ depletion is given in Table 1. The composition is for those Zircaloy fuels that contain stainless steel. Approximately 75 percent of Zircaloy fuels that would be processed do not contain stainless steel. Fission and transuranic products are based on two years after discharge from the reactor. Their totaled masses include decay products. 
Table 1. Zircaloy Spent Fuel Composition per $100 \mathrm{Kg}$ Total Fuel Mass

\begin{tabular}{|c|c|}
\hline Component & Mass (Kilograms) \\
\hline $\mathrm{Zr}$ & 91.958 \\
\hline $\mathrm{Sn}$ & 1.356 \\
\hline $\mathrm{Fe}$ & 1.115 \\
\hline $\mathrm{Cr}$ & 0.36 \\
\hline $\mathrm{Ni}$ & 0.224 \\
\hline$O$ in Zircaloy and as film & 0.84 \\
\hline Misc. Components & 1.13 \\
\hline$B$ & 0.011 \\
\hline$C$ & 0.003 \\
\hline $\mathrm{Li}$ & 0.002 \\
\hline EOL U & 1.823 \\
\hline FPs ${ }^{*}$ & 1.160 \\
\hline TRUs** & 0.01754 \\
\hline Total & 100.00 \\
\hline \multicolumn{2}{|c|}{ 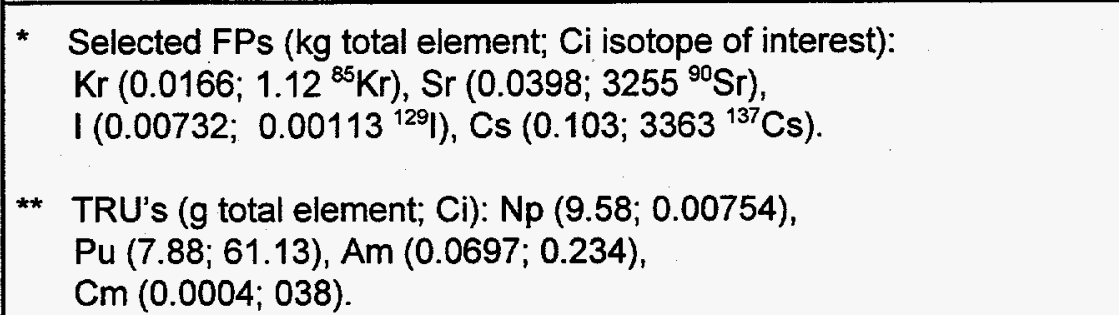 } \\
\hline
\end{tabular}




\section{Aluminum Fuel Composition}

An Advanced Test Reactor (ATR) fuel of typical depletion is used for the characteristic aluminum fuel. The characteristics and composition are given in Table 2.

Table 2. ATR Aluminum Fuel Composition Per $100 \mathrm{Kg}$ Total Fuel Mass

\begin{tabular}{|c|c|}
\hline Component & $\begin{array}{c}\text { Mass } \\
\text { (Kilograms) }\end{array}$ \\
\hline Al as metal (in 6061a and 1100 alloys) & 81.575 \\
\hline $\mathrm{Al}$ as $\mathrm{UAl}_{\mathrm{x}}$ fuel, Al metal portion & 4.619 \\
\hline Total Al & 86.194 \\
\hline Si as 6061 and 1100 Al alloys, Si metal portion & 0.377 \\
\hline EOL $U$ (as $\left.\cup A I_{x}\right), \cup$ metal portion & 8.943 \\
\hline $\begin{array}{l}\text { Fission products and TRUs (based on } 41 \%{ }^{235} \mathrm{U} \\
\text { depletion) }\end{array}$ & 4.483 \\
\hline TOTAL & 100.0 \\
\hline Pu (based on $41 \%$ D) & 0.028 \\
\hline$B O L E_{U-235}$ & 0.93 \\
\hline EOL $E_{U-235}$ at $41 \% \mathrm{D}$ & 0.82 \\
\hline EOL $E_{U-236}$ at $41 \% \mathrm{D}$ & 0.09 \\
\hline EOL $E_{\mathrm{U}-238}$ at $41 \% \mathrm{D}$ & 0.09 \\
\hline
\end{tabular}

EOL: End of life

BOL: Beginning of life 
Stainless Steel Fuel Composition

A fuel composition of typical burnup depletion is used for the characteristic stainless steel cladded fuel (EBR-II). The characteristics and composition are given in Table 3.

Table 3. Representative SS Fuel Composition

\begin{tabular}{|c|c|}
\hline Characteristic & $\begin{array}{c}\text { Mass/Assembly } \\
\text { (91 Pins/Assembly) }\end{array}$ \\
\hline \multicolumn{2}{|l|}{ Component Mass (BOL Kg) } \\
\hline Subassembly Total & 25.48 \\
\hline Subassembly hardware & 18.26 \\
\hline Total Pins (91) & 7.22 \\
\hline Pin Cladding (SS 304) & 2.39 \\
\hline Uranium $(66.7 \%)$ & 4.49 \\
\hline Fissium & 0.235 \\
\hline Sodium Metal & 0.12 \\
\hline \multicolumn{2}{|l|}{ Fissium (grams) } \\
\hline Molybdenum & 114.7 \\
\hline Ruthenium & 91.0 \\
\hline Rhodium & 12.7 \\
\hline Palladium & 9.1 \\
\hline Zirconium & 4.0 \\
\hline Niobium & 0.7 \\
\hline Silicon & 2.4 \\
\hline \multicolumn{2}{|l|}{ Fuel at Discharge (grams) } \\
\hline Uranium at Discharge & 3900." \\
\hline Uranium-235 at Discharge & 2330." \\
\hline \multicolumn{2}{|c|}{ Uranium Isotope Distribution (At. \%) } \\
\hline Uranium-234 & $<1$ \\
\hline Uranium-235 & 60.0 \\
\hline Uranium-236 & 2.9 \\
\hline Uranium-238 & 37.1 \\
\hline Total Plutonium (gm) & 22. \\
\hline Krypton-85 (cc at STP) & 125. \\
\hline
\end{tabular}




\section{Graphite Fuel Composition}

A fuel composition of typical burnup is used for the characteristic graphite fuel. The characteristics and composition of Ft. St. Vrain and Peach Bottom are given in Table 4.

Table 4. Graphite Fuel Composition

\begin{tabular}{||c|c|c|}
\hline \multicolumn{1}{|c|}{ Characteristic } & FSVR-HTGR & Peach Bottom \\
\hline Component Mass (BOL) (Kg/Element) & & \\
\hline Fuel Element Total & 128. & 41. \\
\hline Matrix Carbon & 86. & - \\
\hline Fuel Rod Carbon & 4.08 & - \\
\hline Particle Carbon Coats & 20.04 & - \\
\hline Silicon Carbide & 4.1 & 0. \\
\hline Thorium & 13.154 & -1.5 \\
\hline Uranium (93.5\% leachment) & 0.626 & $\sim 0.30$ \\
\hline Major Transuranics (EOL) (gm/Element) & & \\
\hline Uranium-238 & 32. & -20. \\
\hline Uranium-235 & 177. & 139. \\
\hline Uranium-233 & 237. & 29. \\
\hline Uranium-236 & 70. & $\sim 20$. \\
\hline Uranium-232 (PPM MAX, Total U Base) & 220. & - \\
\hline Thorium-232 & $12,720$. & - \\
\hline Plutonium-238 & 0.9 & - \\
\hline Plutonium-239 & 0.7 & 0.5 \\
\hline Mixed Fission Products (gm/Element) & 870. & - \\
\hline Burnup, MWD/MTIHM & $<50,000$. & $35,000-73,000$ \\
\hline
\end{tabular}




\section{Commercial LWR Fuel Composition}

The generic characteristics of LWR spent fuel are based on pressurized water reactor fuel (PWR) and taken from the ORNL document titled "Decay Characteristics of Once-Through LWR and LMFBR Spent Fuels, High-Level Wastes, and Fuel-Assembly Structural Material Wastes" (ORNL/TM-7431, November 1980). The characteristics for end of life (EOL) composition given below assume a $3.3 \%$ beginning of life (BOL) enrichment, $76 \%$ burnup ( $33.0 \mathrm{MWd} / \mathrm{kg}$ ), and a 10 -year cooling time.

The generic PWR fuel has about the same chemical composition as boiling water reactor (BWR) fuel, but a slightly higher fission product yield (about $17 \%$ ) and actinide content (about 11\%) per metric ton of initial heavy metal (MTIHM) at the 10-year cooling time. Therefore, conceptual flowsheets based on PWR fuel would adequately describe process flowrates and mass balances for BWR fuel also. Major fuel assembly constituents are given in Table 5.

Table 5. PWR-Fuel Assembly Constituents at BOL

\begin{tabular}{|c|c|c|}
\hline Constituent & Weight (kg) & \% by Weight \\
\hline $\mathrm{UO}_{2}$ & 523.4 & 79.6 \\
\hline Zircaloy-4 & 108.4 & 16.4 \\
\hline Hardware & 26.1 & 4.0 \\
\hline Total: & 657.9 & 100.0 \\
\hline
\end{tabular}

The primary chemical components of Zircaloy-4 are $\mathrm{Zr}(98.2 \%), \mathrm{Sn}(1.45 \%), \mathrm{Fe}(0.21 \%)$, and $\mathrm{Cr}$ $(0.10 \%)$. The assembly hardware has components containing Inconel-718, Stainless Steel 304, and Zircaloy-4. The composite chemical composition of these three types of alloys in the hardware is $\mathrm{Fe}(39.5 \%), \mathrm{Zr}(31.4 \%), \mathrm{Ni}(16.1 \%)$, and $\mathrm{Cr}(13.0 \%)$. When the chemical composition, in weight fractions, of the Zircaloy-4 and hardware are multiplied times the percent by weight of the constituents in Table 5, the BOL chemical composition of generic PWR fuel is: $\mathrm{UO}_{2}(79.6 \%), \mathrm{Zr}(17.4 \%), \mathrm{Fe}(1.6 \%), \mathrm{Ni}(0.6 \%), \mathrm{Cr}(0.5 \%)$, and $\mathrm{Sn}(0.2 \%)$.

The (EOL) uranium in spent PWR fuel is given as $9.562 \times 10^{5} \mathrm{~g} / \mathrm{MTIHM}$ (Table A.8 of ORNL/TM-7431), which indicates that $4.379 \%$ of the initial uranium $(235+238)$ undergoes fissioning and transmutation. For chemical flowsheet development, the $4.379 \%$ of converted uranium can be categorized as fission product ( $\mathrm{FP}$ ) $\mathrm{Zr}$, volatile $\mathrm{FPs}(\mathrm{Xe}, \mathrm{Kr}, \mathrm{I}$, and $\mathrm{Br}$ ), nonvolatile FPs, and TRUs. 
The BOL $\mathrm{UO}_{2}$ from Table 5 corresponds to the BOL elemental uranium content of $70.1 \%$ by weight (i.e., 238/270 times the $\mathrm{BOL} \mathrm{UO}_{2}$ content). Therefore the $\mathrm{EOL}$ uranium in the PWR fuel is $0.701-(.0438 \times .701)=0.670$ or $67.0 \mathrm{wt} \%$, which corresponds to $76.0 \mathrm{wt} \% \mathrm{UO}_{2}$. For flowsheet calculations, the $\mathrm{g}, \mathrm{Ci}$, and watts of the principal FPs $(99.97 \%$ of contributors to mass and $\mathrm{Ci}$ ) are given in Table 6 . The values in the table can be converted to $\mathrm{g}, \mathrm{Ci}$, or watts per 100 $\mathrm{kg} /$ fuel by the multiplier 0.0701 (i.e., divided by 10 and multiply by the initial heavy metal (IHM) fraction of the fuel $=0.701$ ).

The EOL TRUs of significant weight and curies are Np, Pu, Am and Cm (Table A.8 of ORNL/TM-7431). The TRUs amount to $9730 \mathrm{~g} / \mathrm{MTIHM}$, which correlates to $682 \mathrm{~g} / 100 \mathrm{~kg}$ of fuel. For flowsheet calculations, the $\mathrm{g}, \mathrm{Ci}$, and watts of the four TRUs are reproduced in Table 7 . The values in Table 7 can be converted to $\mathrm{g}, \mathrm{Ci}$, or watts per $100 \mathrm{~kg} /$ fuel by the multiplier 0.0701 .

The FP mass from Table 6 is $34.060 \mathrm{~kg}$ and the TRU mass from Table 7 is $9.73 \mathrm{~kg}$, which gives a total of $43.79 \mathrm{~kg}$ (TRUs + FPs)/MTIHM produced and equals the amount of MTIHM uranium converted (4.379\%). Using values from Table 6 and the conversion factor 0.0701 indicates the following FP yields: $0.25 \mathrm{~kg} \mathrm{Zr}, 0.417 \mathrm{~kg}$ volatile isotopes (Xe, $\mathrm{Kr}, \mathrm{Br}, \& \mathrm{I})$, and $1.72 \mathrm{~kg}$ nonvolatile isotopes per $100 \mathrm{~kg}$ fuel. Based on the analysis in Table 5, Table 6, and Table 7, the EOL composition of 10-yr cooled PWR fuel in percent by weight is given in Table 8.

The residual $\mathrm{O}_{2}$ is left over from the converted uranium and would exist as oxides of other metals. Rounding errors account for the missing $0.06 \%$ of mass. The values for FP, TRU, and EOL compositions in Table 6, Table 7, and Table 8 are used to develop the conceptual flow sheet for pyrochemical processing of LWR fuels in Chapter 4.2. 
Table 6. FP Content (g, Ci, watt) ${ }^{\mathrm{a}}$ of 10-yr Cooled PWR Fuel

\begin{tabular}{|c|c|c|c|}
\hline FP & g/MTIHM & Ci/MTIHM & watt/MTIHM \\
\hline $\mathrm{H}$ & 0 & 312 & 0 \\
\hline $\mathrm{Se}$ & 56 & 0 & 0 \\
\hline $\mathrm{Br}$ & 22 & 0 & 0 \\
\hline $\mathrm{Kr}$ & 358 & 4955 & 7 \\
\hline $\mathrm{Rb}$ & 353 & 0 & 0 \\
\hline $\mathrm{Sr}$ & 773 & 57650 & 67 \\
\hline$Y$ & 456 & 57660 & 320 \\
\hline $\mathrm{Zr}$ & 3620 & 2 & 0 \\
\hline Mo & 3337 & 0 & 0 \\
\hline TC & 771 & 13 & 0 \\
\hline $\mathrm{Ru}$ & 2179 & 601 & 0 \\
\hline $\mathrm{Rh}$ & 467 & 601 & 6 \\
\hline $\mathrm{Pd}$ & 1371 & 0 & 0 \\
\hline $\mathrm{Ag}$ & 76 & 0 & 0 \\
\hline $\mathrm{Cd}$ & 108 & 35 & 0 \\
\hline In & 3 & 0 & 0 \\
\hline$S n$ & 90 & 0 & 0 \\
\hline $\mathrm{Sb}$ & 20 & 1229 & 4 \\
\hline $\mathrm{Te}$ & 484 & 300 & 0 \\
\hline 1 & 235 & 0 & 0 \\
\hline$\overline{X e}$ & 5333 & 0 & 0 \\
\hline Cs & 2382 & 88210 & 147 \\
\hline $\mathrm{Ba}$ & 1724 & 78310 & 308 \\
\hline La & 1216 & 0 & 0 \\
\hline $\mathrm{Ce}$ & 2365 & 0 & 0 \\
\hline $\mathrm{Pr}$ & 1116 & 1 & 1 \\
\hline $\mathrm{Nd}$ & 4025 & 0 & 0 \\
\hline $\mathrm{Pm}$ & 11 & 4 & 4 \\
\hline $\mathrm{Sm}$ & 861 & 0 & 0 \\
\hline $\mathrm{Eu}$ & 132 & 43 & 43 \\
\hline$G d$ & 116 & 0 & 0 \\
\hline Total: & 34060 & 306630 & 894 \\
\hline
\end{tabular}

a Less than $1 \mathrm{~g}, \mathrm{Ci}$, or watt set equal to zero. 
Table 7. TRU Content (g, Ci, watt) of 10-yr Cooled PWR Fuel

\begin{tabular}{|c|c|c|c|}
\hline TRU & g/MTIHM & Ci/MTIHM & watt/MTIHM \\
\hline $\mathrm{Np}$ & 447 & 17 & 0.05 \\
\hline $\mathrm{Pu}$ & 8691 & 80974 & 102.03 \\
\hline $\mathrm{Am}$ & 579 & 1716 & 56.70 \\
\hline $\mathrm{Cm}$ & 13 & 1055 & 36.80 \\
\hline Total: & 9730 & 83762 & 195.58 \\
\hline
\end{tabular}

Table 8. EOL Composition of 10-yr Cooled PWR Fuel

\begin{tabular}{|c|r|}
\hline Species & \% by Weight \\
\hline $\mathrm{UO}_{2}$ & 76.04 \\
\hline $\mathrm{Zr}$ & 17.65 \\
\hline $\mathrm{Fe}$ & 1.60 \\
\hline $\mathrm{Ni}$ & 0.64 \\
\hline $\mathrm{Cr}$ & 0.53 \\
\hline $\mathrm{Sn}$ & 0.24 \\
\hline $\mathrm{TRUs}$ & 0.68 \\
\hline Volatile FPs & 0.42 \\
\hline Non-volatile FPs & 1.72 \\
\hline Residual $\mathrm{O}_{2}$ & 0.42 \\
\hline Total: & 99.94 \\
\hline \hline
\end{tabular}

\subsection{Calcine Composition}

The assumed radionuclide content and composition of inert components in the calcine are listed in Table 9. These inventories are believed to adequately reflect the compositional makeup of actual calcines, which are cited conservatively high to reflect "worst" case processing conditions. 
Table 9. Assumed Stored Calcine Composition

\begin{tabular}{|c|c|c|c|}
\hline Inert Elements & $\begin{array}{c}\text { Aluminum Calcine } \\
1 \mathrm{~kg} \text { (Basis) } \\
\text { Kg Element }\end{array}$ & $\begin{array}{c}\text { Zirconium Calcine } \\
1 \mathrm{~kg} \text { (Basis) } \\
\mathrm{Kg} \text { Element }\end{array}$ & $\begin{array}{c}\text { Zr-Na Calcine } \\
1 \mathrm{~kg} \text { (Basis) } \\
\mathrm{Kg} \text { element }\end{array}$ \\
\hline Al & $4.79 e-01$ & $7.62 e-02$ & $7.46 e-02$ \\
\hline $\mathrm{B}$ & $1.86 \mathrm{e}-03$ & $9.32 \mathrm{e}-03$ & $7.76 \mathrm{e}-03$ \\
\hline $\mathrm{Ca}$ & $2.00 e-02$ & $3.07 e-01$ & $3.19 e-01$ \\
\hline$F$ & $2.00 \mathrm{e}-02$ & $2.64 e-01$ & $2.16 e-01$ \\
\hline$\overline{\mathrm{Fe}}$ & $4.20 \mathrm{e}-03$ & $6.99 e-04$ & $2.10 \mathrm{e}-03$ \\
\hline $\mathrm{Hg}$ & $2.90 \theta-02$ & $5.000-04$ & \\
\hline$k$ & $7.50 \mathrm{e}-04$ & $1.00 e-03$ & $4.70 e-03$ \\
\hline $\mathrm{Mn}$ & $5.00 \mathrm{e}-03$ & $5.000-04$ & \\
\hline $\mathrm{Na}$ & $2.300-02$ & $7.00 \mathrm{e}-03$ & $3.34 e-02$ \\
\hline NO3 & $1.00 \mathrm{e}-02$ & $1.000-02$ & $8.00 \mathrm{e}-02$ \\
\hline PO4 & & & $2.00 e-03$ \\
\hline $\mathrm{SO} 4$ & $1.200-02$ & & $3.00 e-03$ \\
\hline $\mathrm{Zr}$ & $5.000-03$ & $1.73 \theta-01$ & $1.410-01$ \\
\hline Actinides & (Ci/kg) & (Cilkg) & (Ci/kg) \\
\hline Am-241 & $9.100-04$ & $9.10 e-04$ & $9.100-04$ \\
\hline $\mathrm{Am}-243$ & $8.30 \mathrm{e}-06$ & $8.300-06$ & $8.300-06$ \\
\hline $\mathrm{Cm}-242$ & $6.500-04$ & $6.50 e-04$ & $6.50 \mathrm{e}-04$ \\
\hline $\mathrm{Cm}-244$ & $5.20 \mathrm{e}-04$ & $5.20 \mathrm{e}-04$ & $5.20 e-04$ \\
\hline Np-237 & $3.55 \mathrm{e}-06$ & $7.100-07$ & $3.55 \mathrm{e}-06$ \\
\hline Pu-238 & $7.00 e-02$ & $7.000-02$ & $7.00 \mathrm{e}-02$ \\
\hline Pu-239 & $7.000-04$ & $7.00 \mathrm{e}-0.4$ & $7.000-04$ \\
\hline Pu-240 & $6.500-04$ & $6.50 \mathrm{e}-04$ & $6.50 \mathrm{e}-04$ \\
\hline Pu-241 & $1.60 \mathrm{e}-01$ & $1.60 \mathrm{e}-01$ & $1.600-01$ \\
\hline Pu-242 & $1.80 \mathrm{e}-06$ & 1. $80 \mathrm{e}-06$ & $1.800-06$ \\
\hline$U-233$ & $1.200-12$ & $1.200-12$ & $1.20 \mathrm{e}-12$ \\
\hline $\mathrm{U}-234$ & $4.300-10$ & $4.300-10$ & $4.300-10$ \\
\hline U-235 & $1.80 \mathrm{e}-09$ & $1.80 \mathrm{e}-09$ & $1.800-09$ \\
\hline U-236 & $1.00 e-08$ & $1.000-08$ & $1.000-08$ \\
\hline U-237 & $4.80 \mathrm{e}-12$ & $4.800-12$ & $4.800-12$ \\
\hline $\mathrm{U}-238$ & $10.00 \mathrm{e}-15$ & $10.000-15$ & $10.00 e-15$ \\
\hline Totals & $2.33 e-01$ & $2.33 e-01$ & $2.33 e-01$ \\
\hline Fission Products & (Ci/kg) & (Cikg) & $(\mathrm{C} / \mathrm{kg})$ \\
\hline$B a-137 m$ & $1.20 \mathrm{e}+01$ & $1.20 e+01$ & $1.200+01$ \\
\hline Ce-144 & $8.20 \mathrm{e}+00$ & $8.20 \mathrm{e}+\infty 0$ & $8.200+00$ \\
\hline Cs-134 & $3.30 e+00$ & $3.30 e+00$ & $3.300+\infty$ \\
\hline Cs-135 & $7.50 \mathrm{e}-05$ & $7.500-05$ & $7.500-05$ \\
\hline Cs-137 & $1.30 e+01$ & $1.30 \mathrm{e}+01$ & $1.300+01$ \\
\hline Eu-154 & $1.80 \mathrm{e}-01$ & $1.800-01$ & $1.80 \mathrm{e}-01$ \\
\hline $\mathrm{Nb}-93 \mathrm{~m}$ & $7.50 \mathrm{e}-05$ & $7.500-05$ & $7.50 e-05$ \\
\hline$P d-107$ & $2.000-06$ & $2.00 e-06$ & $2.00 e-06$ \\
\hline$P m-147$ & $1.20 e+01$ & $1.200+01$ & $1.20 e+01$ \\
\hline Pr-144 & $8.20 e+00$ & $8.20 \mathrm{e}+00$ & $8.200+00$ \\
\hline $\mathrm{Rb}-87$ & $3.60 \mathrm{e}-09$ & $3.600-09$ & $3.600-09$ \\
\hline Rh-106 & $9.700-01$ & $9.70 \mathrm{e}-01$ & $9.70 \mathrm{e}-01$ \\
\hline$R u-106$ & $9.700-01$ & $9.700-01$ & 9.70e-01 \\
\hline$S b-126$ & $3.200-05$ & $3.20 e-05$ & $3.20 \mathrm{e}-05$ \\
\hline Sb-126m & $3.20 \mathrm{e}-05$ & $3.20 \mathrm{e}-05$ & $3.200-05$ \\
\hline Se-79 & $6.400-05$ & $6.400-05$ & $6.40 e-05$ \\
\hline $\mathrm{Sm}-151$ & $1.70 \mathrm{e}-01$ & $1.700-01$ & $1.70 \mathrm{e}-01$ \\
\hline$S n-126$ & $3.20 \mathrm{e}-05$ & $3.200-05$ & $3.200-05$ \\
\hline Sr-90 & $1.30 e+01$ & $1.30 e+01$ & $1.30 \mathrm{e}+01$ \\
\hline Tc-99 & $2.10 \mathrm{e}-03$ & $2.100-03$ & $2.100-03$ \\
\hline$Y-90$ & $1.30 \mathrm{e}+01$ & $1.300+01$ & $1.30 \theta+01$ \\
\hline $\mathrm{Zr}-93$ & $3.10 e-04$ & $3.10 \theta-04$ & $3.100-04$ \\
\hline Totals & $8.50 e+01$ & $8.50 e+01$ & $8.50 e+01$ \\
\hline
\end{tabular}

Ref: Environmental Evaluation of Alternatives for Long-Term Management of Defense High-Level Radioactive Wastes at Idaho Chemical Processing Plant, IDO-10105, September 1982 


\subsection{Sodium Waste Composition}

The chemical and radiochemical composition of sodium-bearing liquid waste has been updated recently to reflect the expected composition of waste which must be processed in the future. Tables 10 and 11 list the compositions.

Table 10. Chemical Composition of Sodium-Bearing Waste

\begin{tabular}{|c|c|c|c|}
\hline \multirow[b]{2}{*}{ Component } & \multirow{2}{*}{$\begin{array}{c}\text { Apparent } \\
\text { Molar Volume } \\
\mathrm{m}^{3} / \text { mole }\end{array}$} & \multicolumn{2}{|c|}{ Mass per $\mathrm{m}^{3}$} \\
\hline & & gms & - moles \\
\hline Acid $\left(\mathrm{H}^{+}\right)$ & 0 & $1,577.5$ & $1,565.0$ \\
\hline Hydroxide $\left(\mathrm{OH}^{-}\right)$ & -0.00000404 & - & \\
\hline Boron $\left(\mathrm{B}^{3+}\right)$ & 0.00005575 & 194.6 & 18.0 \\
\hline Sodium $\left(\mathrm{Na}^{+}\right)$ & -0.00000121 & $43,611.7$ & $1,897.0$ \\
\hline Aluminum $\left(\mathrm{Al}^{3+}\right)$ & -0.0000422 & $17,268.2$ & 640.0 \\
\hline Potassium $\left(\mathrm{K}^{+}\right)$ & 0.00000902 & $8,015.9$ & 205.0 \\
\hline Calcium $\left(\mathrm{Ca}^{2+}\right)$ & -0.00001785 & $2,124.2$ & 53.0 \\
\hline Chromium $\left(\mathrm{Cr}^{3+}\right)$ & -0.0000395 & 192.4 & 3.7 \\
\hline Manganese $\left(\mathrm{Mn}^{2+}\right)$ & -0.0000177 & 879.0 & 16.0 \\
\hline Iron $\left(\mathrm{Fe}^{2+}\right)$ & -0.0000247 & $1,228.6$ & 22.0 \\
\hline Nickel $\left(\mathrm{Ni}^{2+}\right)$ & -0.000024 & 93.9 & 1.6 \\
\hline Zirconium $\left(\mathrm{Zr}^{\mathrm{S}^{+}}\right)$ & 0.00011594 & 182.4 & 2.0 \\
\hline Molybdenum $\left(\mathrm{Mo}^{6+}\right)$ & -0.0000395 & 67.2 & 0.7 \\
\hline Cadmium $\left(\mathrm{Cd}^{2+}\right)$ & -0.00002 & 314.7 & 2.8 \\
\hline Lead $\left(\mathrm{Pb}^{2+}\right)$ & -0.0000155 & 290.1 & 1.4 \\
\hline Mercury $\left(\mathrm{Hg}^{2+}\right)$ & -0.0000193 & 220.6 & 1.1 \\
\hline Fluoride (F) & -0.00000116 & $1,310.9$ & 69.0 \\
\hline Chloride $(\mathrm{Cl})$ & 0.00001783 & $1,028.1$ & 29.0 \\
\hline Nitrate $\left(\mathrm{NO}_{3}{ }^{-}\right)$ & 0.000029 & $348,933.0$ & $5,627.5$ \\
\hline Phosphate $\left(\mathrm{PO}_{4}{ }^{3}\right)$ & 0.0000291 & $1,804.5$ & 19.0 \\
\hline Sulphate $\left(\mathrm{SO}_{4}{ }^{2-}\right)$ & 0.00001398 & $4,803.1$ & 50.0 \\
\hline Undiss. Solids & & $2,488.0$ & \\
\hline Water $\left(\mathrm{H}_{2} \mathrm{O}\right)$ & & $763,249.3$ & $42,366.6$ \\
\hline Density $\left(\mathrm{kg} / \mathrm{m}^{3}\right)$ & - & & \\
\hline
\end{tabular}


Densities for aqueous solutions, unless otherwise noted, will be calculated from apparent (partial) molar volumes of the components according to the following equation (Reference $A N L-89 / 18$ ):

$$
d=1000 .+\sum_{i} \frac{\left(\frac{M W_{i}}{1000 .}-1000 . V_{\phi, i}\right) N_{i}}{1000 .}
$$

where: $\mathrm{d}=$ density in $\mathrm{kg} / \mathrm{m}^{3}$

$\mathrm{MW}_{\mathrm{i}}=$ Molecular weight of component $\mathrm{I}, \mathrm{gm} / \mathrm{mole}$

$\mathrm{V}_{\phi, \mathrm{i}}=$ Apparent (partial) molar volume of component $\mathrm{I}, \mathrm{mol} / \mathrm{m}^{3}$

$\mathrm{N}_{\mathrm{i}}=$ Number of moles of component I

Nitrate values in Table 10 are based on a charge balance, rather than the analytical analysis value. The solution would be ionically unbalanced if this were not done.

Table 11. Radiochemical Composition of Sodium-Bearing Waste

\begin{tabular}{|c|c|c|c|}
\hline \multirow{2}{*}{ Component } & \multirow{2}{*}{$\begin{array}{c}\text { Apparent } \\
\text { Molar Volume } \\
\mathrm{m}^{3} / \text { mole }\end{array}$} & \multicolumn{2}{|c|}{ Mass per $\mathbf{m}^{3}$} \\
\hline & & gms & moles \\
\hline H-3 (Tritium) & 0 & 0.00000342 & 0.00000114 \\
\hline Strontium-90 & -0.00001816 & 0.28 & 0.003 \\
\hline Yttrium-90* & 0 & - & - \\
\hline Technetium-99 & 0.00002283 & 0.64 & 0.006 \\
\hline lodine-129 & 0.00003622 & 10.59 & 0.08 \\
\hline Cesium-137 & 0.00002134 & 0.47 & 0.003 \\
\hline Barium-137 & 0 & - & - \\
\hline Actinides & 0.00001591 & 92.77 & 0.39 \\
\hline
\end{tabular}

Yttrium-90 and Barium-137 are in secular equilibrium with Strontium-90 and Cesium-137 respectively. They are included here because they are needed to make heat calculations. 


\subsection{Low-Level Waste Classifications}

Table 12 provides classifications for LLW derived from 10 CFR 61. These limits provide the basis for determining the allowable radionuclide concentrations in grout formulations.

Table 12. LLW Concentration Limits

\begin{tabular}{|c|c|c|c|}
\hline \multirow{2}{*}{ Radionuclide } & \multicolumn{3}{|c|}{ Concentration $\left(\mathbf{C i} / \mathbf{m}^{3}\right)$} \\
\cline { 2 - 4 } & Class A & Class B & Class C \\
\hline${ }^{3} \mathrm{H}$ & 40 & - & - \\
\hline${ }^{63} \mathrm{Ni}$ & 3.5 & 70 & 700 \\
\hline${ }^{90} \mathrm{Sr}$ & 0.04 & 150 & 7,000 \\
\hline${ }^{137} \mathrm{Cs}$ & 1 & 44 & 4,600 \\
\hline${ }^{14} \mathrm{C}$ & & 0.8 & 8 \\
\hline${ }^{99} \mathrm{Tc}$ & 0.3 & 3 \\
\hline${ }^{129} \mathrm{I}$ & \multicolumn{2}{|c|}{0.008} & 0.08 \\
\hline${ }^{241} \mathrm{Pu}$ & $350 \mathrm{nCi} / \mathrm{g}$ & $3,500 \mathrm{nCi} / \mathrm{g}$ \\
\hline $\begin{array}{l}\text { Transuranic } \\
\text { Radionuclides with } \mathrm{t}_{1 / 2}\end{array}$ & $10 \mathrm{nCi} / \mathrm{g}$ & $\mathrm{nCi} / \mathrm{g}$ \\
\hline 5 yrs
\end{tabular}




\subsection{Unit Operations Used in Building Waste Disposal Alternatives}

Options for final disposal of SNF, calcine waste, and radioactive liquid waste are comprised of several unit operations linked together, which then constitute the overall alternative. Later sections of this study will present alternatives for waste disposal which use the same unit operation. The following section describes technologies and unit operations included in more than one alternative in order to avoid redundancy. Each unit operation will include a technology description, assumptions made in calculating mass balances, and major issues requiring resolution through development. Those alternatives having technologies unique to them will have descriptions within the section for that alternative.

\section{CALCINATION}

Calcination is a thermal process which converts liquid waste containing metal salts into a granular solid waste. A process schematic is shown in Figure 3. Liquid wastes blended with additives and/or with other tank farm wastes are sprayed into a hot, air-fluidized bed of granular solids where volatile components are flashed off and the metallic salts are converted to oxides.

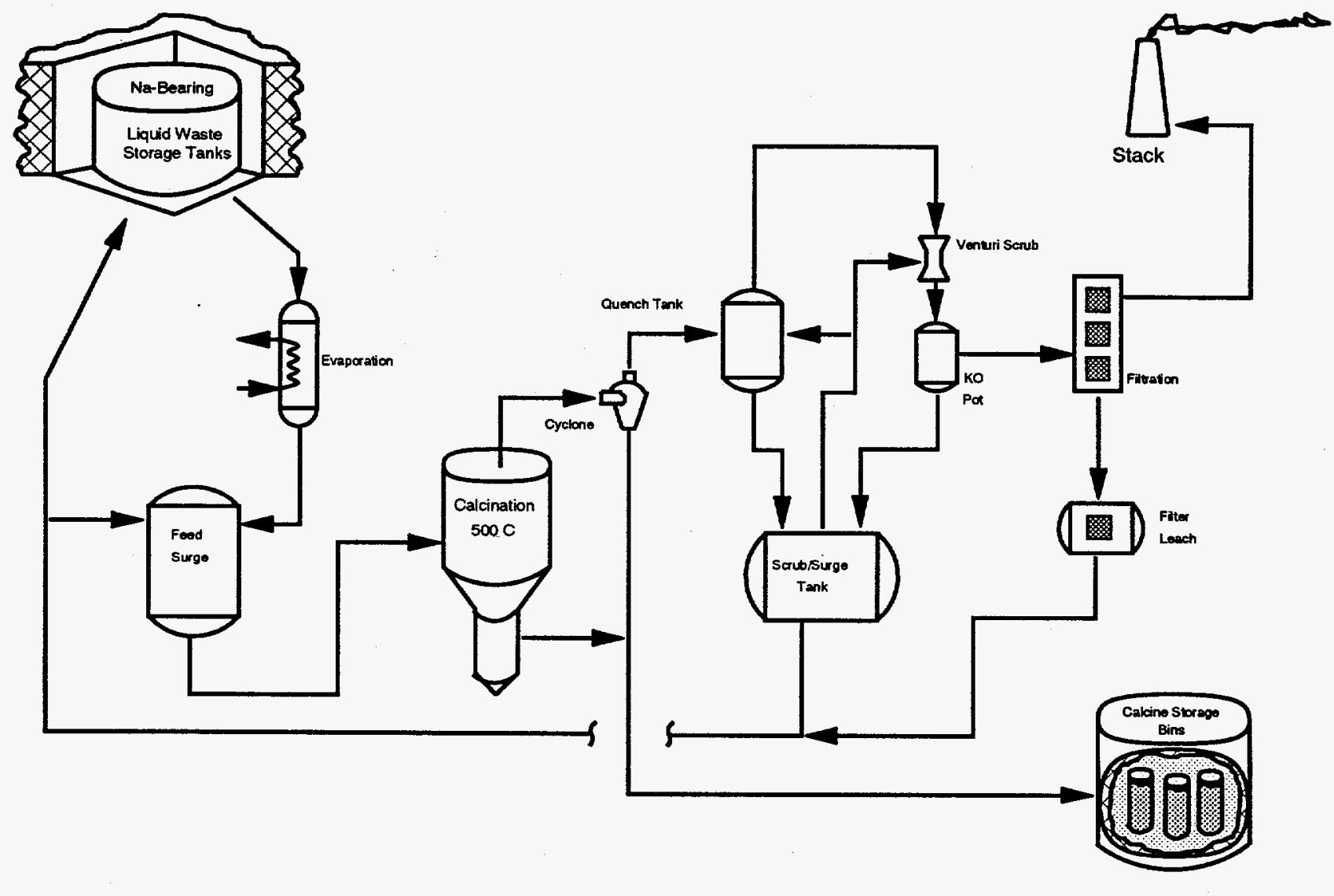

Figure 3. Calcination Process 
The fluidized bed is maintained at a temperature of $500^{\circ} \mathrm{C}$ by the in-bed combustion of kerosene. The calciner vessel off-gas is passed through a cyclone, where a large portion of the entrained fine particles is settled out. These fines are then combined with the larger solids that were removed via the product takeoff lines. The off-gas is then treated by passing it through a quench tower to cool the gas and remove some moisture and solid particles. Treatment through a venturi scrubber and demister follows the treatment with the quench tower. Scrub solution is continually recirculated through the quench tower and venturi scrubber. The solutions generated from the operation of the quench tower, venturi scrubber and demister return to the scrub solution tank and a portion of this scrub solution is recycled back to the calciner feed. The off-gas then passes through a heat exchanger, silica gel beds, demister, superheater, HEPA filters and is then exhausted to the Atmospheric Protection System (APS). The APS air stream is exhausted to the main stack.

\section{Assumptions Used in Completing Mass Balance Calculations}

Process flow rates were estimated from recent calciner operating experiences and the projected NWCF operating cycle (18 months of operation, 12 months of maintenance). The quantity and composition of the calcine waste product produced was calculated by calcine product formation rules based on pilot-plant tests and calcine characterizations. Additional calcine product assumptions include the following:

- Calciner average production rate is $130 \mathrm{gal} / \mathrm{hr}(150 \mathrm{gal} / \mathrm{hr}$ with recycle $)$.

- The calciner operates $70 \%$ of the on-line time, accounting for excursions, filter changeouts, etc.

- An 8.4\% Na+K mole\% was assumed for all calcine product. This is the average of the present Technical Specification of $5.3 \mathrm{~mole} \%$ and the proposed $11.5 \mathrm{~mole} \%$.

- Sodium plus Potassium $(\mathrm{Na}+\mathrm{K})$ mole $\%$ in the calcine is calculated according to the following:

$$
(\mathrm{Na}+K) \mathrm{mo} \%=\left(\frac{(\mathrm{Na}+K)}{\left(\text { Metals }+\mathrm{O}+\mathrm{NO}_{3}^{-}+\mathrm{PO}_{4}^{2-}+\mathrm{SO}_{4}^{2-}+\mathrm{F}^{-}+\mathrm{Cl} \mathrm{I}^{-}\right)}\right) \times 100
$$

All concentrations are in moles. Oxygen $(0)$ is the number of moles associated with the metal oxides.

Calcine density for alumina-based calcines is $1.1 \mathrm{~g} / \mathrm{cm}^{3}$. The bulk density for a blend of Fluorinel and Sodium waste is $1.6 \mathrm{~g} / \mathrm{cm}^{3}$. The bulk density of blends from the tanks is 1.4 $\mathrm{g} / \mathrm{cm}^{3}$. (B. A. Staples, G. S. Pomiak, E. L. Wade, ICP-1189, "Properties of Radioactive 
Calcine Retrieved from the Second Calcined Solids Storage Facility at ICPP, March 1979. J. R. Berreth, WINCO-1050, "Inventories and Properties of ICPP Calcined High-Level Waste, "February 1988.)

- $\quad$ For additives the following will be used:

\author{
Component \\ Aluminum Nitrate $\left(\mathrm{Al}\left(\mathrm{NO}_{3}\right)_{3}\right)$ \\ Boric Acid $\left(\mathrm{H}_{3} \mathrm{BO}_{3}\right)$ \\ Calcium Nitrate $\left(\mathrm{Ca}\left(\mathrm{NO}_{3}\right)_{2}\right)$
}

\begin{tabular}{ll} 
Molarity & Density \\
\hline 2.2 & 1.3648 \\
0.75 & 1.0143 \\
4.3 & 1.5284
\end{tabular}

For all calcines a $\mathrm{Ca}$ to $\mathrm{F}$ mole ratio of 0.7 will be used and a boron concentration of $0.15 \mathrm{M}$ will be used for calcination with aluminum nitrate.

\section{MAJOR DEVELOPMENT ISSUES}

The ability to process sodium-bearing waste at higher sodium plus potassium waste loadings would decrease the amount of non-radioactive chemical addition and would allow for a quicker processing of the tank farm waste. Pilot plant operations with these feeds have been successful; however, operation with high sodium plus potassium feeds at the facility has not yet been achieved.

Flowsheets will need to be developed to process some of the waste streams that will be produced from the various proposed alternative sodium waste and/or calcine treatment technologies. The technologies that are currently being developed for possible use as alternative sodium waste treatment technologies are freeze crystallization, TRUEX, and electrohydrolysis. All of these treatment technologies will have liquid mixed waste streams that may require calcination, and flowsheet development will be required to ensure that the NWCF will be able to process these waste streams.

\section{CALCINE RETRIEVAL}

Calcine material is currently stored in six Solids Storage Facilities (CSSF). All of the facilities except CSSF-1 have access provided to the calcine in the bins via retrieval risers. The calcine will be pneumatically retrieved from the bins and transported under vacuum to a processing facility. The retrieval system will contain a new structure over the existing CSSF and a deployment apparatus to position the retrieval nozzle in the bins. The processing facility will contain the interim storage tanks, solids separation equipment, filters and the blower that provides the suction for the transport line. Figure 4 depicts the proposed retrieval system. The design retrieval rate is $500 \mathrm{Lbs} / \mathrm{hr}$ but can be adjusted to fit the needs of the treatment facility. The system under consideration will be designed for use in all of the CSSFs. 
The ICPP has extensive experience in the development and operation of pneumatic transport of calcined solids. All of the calcine material in the existing storage facilities was pneumatically transported there from the calcination facilities. Even with this acquired experience, the system will be 'one-of-a-kind' and will require significant applied development activities. Some of these tasks include the following:

- Development of a deployment device to position the retrieval nozzles in the storage bins is needed.

- Development of nozzles that can retrieve free flowing and caked calcine is needed. The nozzles will be designed for specific situations that could be encountered in the various bins.

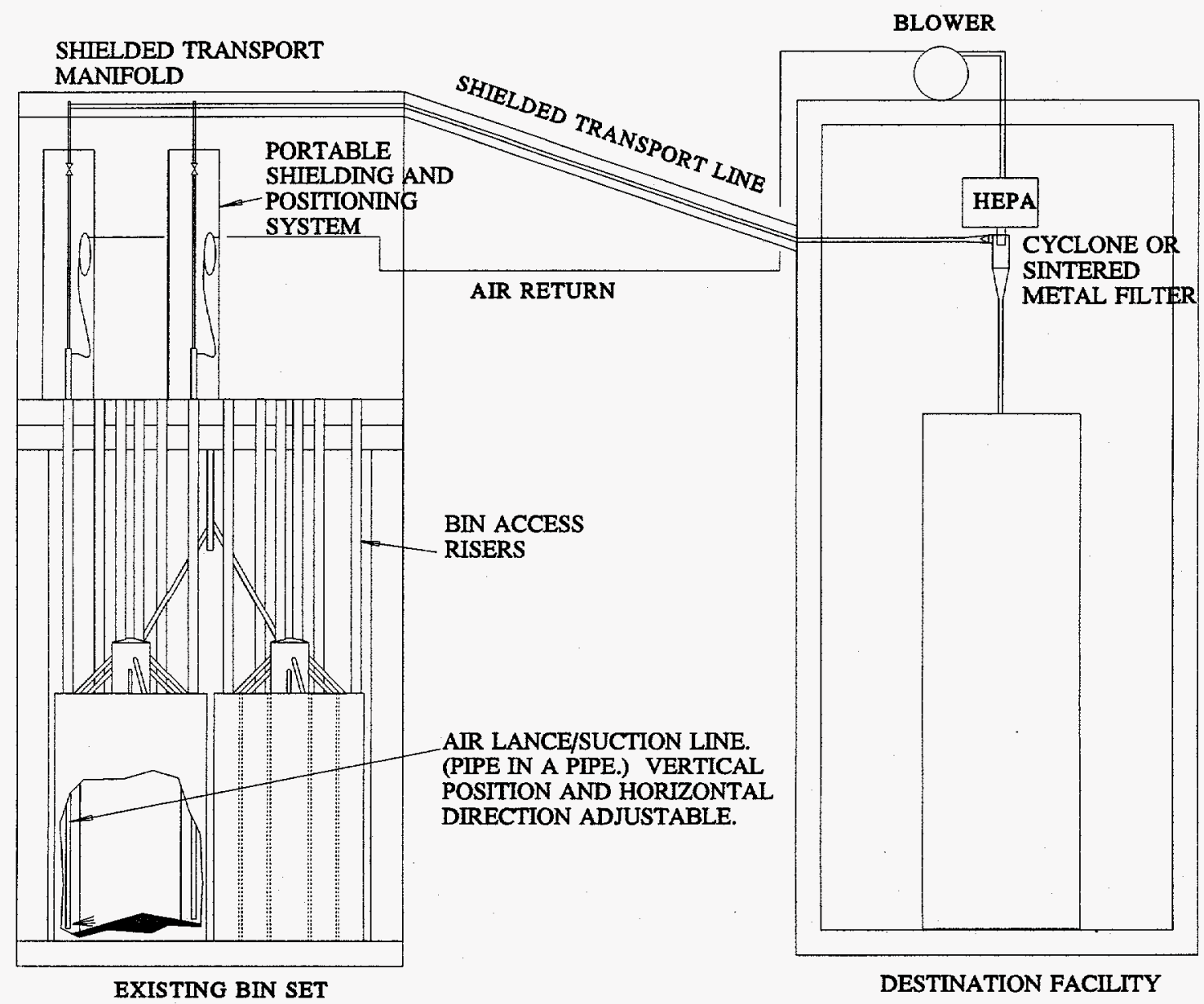

Figure 4. Proposed Retrieval Process for Calcine Material 
- Testing of various commercial sintered metal filters for possible use prior to the HEPA filters at the processing facility will be required.

\section{CALCINE DISSOLUTION}

For aqueous processing partitioning technologies a liquid feed is required. In calcine dissolution the stored granular solids will be converted from a solid to a liquid containing metal cations and non-metal anions. Figure 5 depicts a process schematic. The dissolution process consists of dissolving the calcine in a vessel using nitric acid. The vessel will be heated and stirred to increase the rate of dissolution to practical levels. The overflow from the dissolver will be directed to a settling tank where the bulk of the suspended solids will settle to the bottom. The solids will periodically be returned to the dissolver for rework. The "clear" liquid exiting the settler will be passed through a another solid/liquid separation system as a final polishing step and the output will be the feed for the partitioning processes.

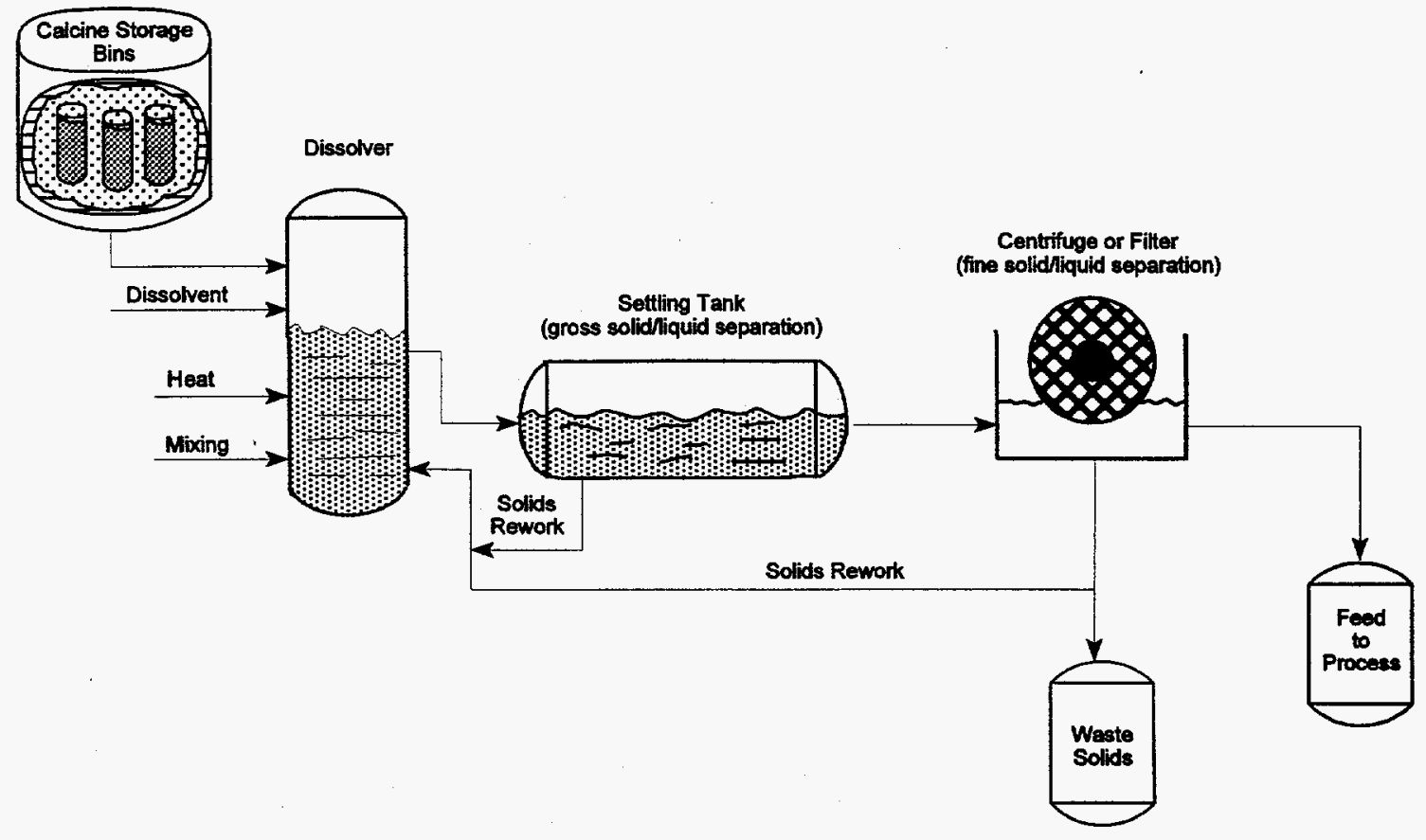

Figure 5. Calcine Dissolution Process 


\section{Assumptions Used in Completing Mass Balance Calculations}

The dissolution assumptions are based on an understanding of basic chemistry and on results of dissolution experiments complete at the ICPP.

- The feed nitric acid concentration will be $5 \underline{M}$, the final free acid concentration for actinide removal feed will be $3 \underline{\mathrm{M}}$, and the final free acid concentration for precipitation will be 0.5 $\underline{\mathrm{M}}$

- $99 \mathrm{wt} \%$ of all calcine constituents dissolve with the following exceptions. For zirconium calcine, calcium is assumed to be present as $\mathrm{CaO}$ and as $\mathrm{CaF}_{2}$; fluoride is assumed to be present only as $\mathrm{CaF}_{2}$. However, $\mathrm{CaF}_{2}$, which is fairly insoluble, is assumed to be present at a mass equivalent to $5 \%$ of the total starting weight of the calcine; in other words, if $1 \mathrm{~kg}$ of calcine is dissolved, $50 \mathrm{~g}$ of $\mathrm{CaF}_{2}$ will remain as undissolved solids.

- The oxygen released during dissolution ( $99 \%$ of that listed as present) combines with free acid to form water.

- The final volume used for molarity calculations was set equal to the initial volume plus the volume of water formed.

\section{MAJOR DEVELOPMENT ISSUES}

The process chemistry must be verified with radioactive calcine to make certain the process will operate as desired.

The specific shape of process vessels that will allow safe operation with respect to nuclear criticality must be determined and tested. The shape of the vessel could negatively impact the rate of dissolution and/or the rate of solid/liquid separation. An acceptable method of solid/liquid contact (mixing) must be determined. While an impeller will work well as a mixer, the use of impellers in a radioactive environment is undesirable because of maintenance concerns.

The equipment for transporting solids in the process must be defined. The major concerns are that the system will upset the settling process or that inadequate solids removal, and subsequent solids buildup will occur.

The necessity for removal of non-settling solids from the "clear" stream must still be determined. This issue will be determined by the choice of partitioning technologies. If removal is necessary, either a centrifuge or a filter system will be required to perform the separation of the small particles $(<10 \mu \mathrm{m})$. Design and testing of the system in a critically safe geometry may be required. 


\section{FREEZE CRYSTALLIZATION}

Freeze crystallization is a developing technology which separates liquids by freezing one or more components to a solid or crystalline phase. A process flow diagram is depicted in Figure 6. The process is operated by removing heat and reducing the solution temperature below the freezing point of one or more of the solution components. Usually only one component in the solution crystallizes; that crystal is pure as a result of the natural rejections of substances which are foreign to the basic crystal structure. The purity is maintained by temperature control in the crystallizer, in which the crystals are formed, which in turn limits the size of the crystals.

The process crystallizer is usually one of three types: 1) direct contact where the solution is injected with an immiscible refrigerant and its evaporation causes heat removal from the solution; 2) indirect contact where the heat is removed from a solution through a heat transfer surface in contact with an evaporating refrigerant; and 3) triple point where the solvent is the refrigerant.

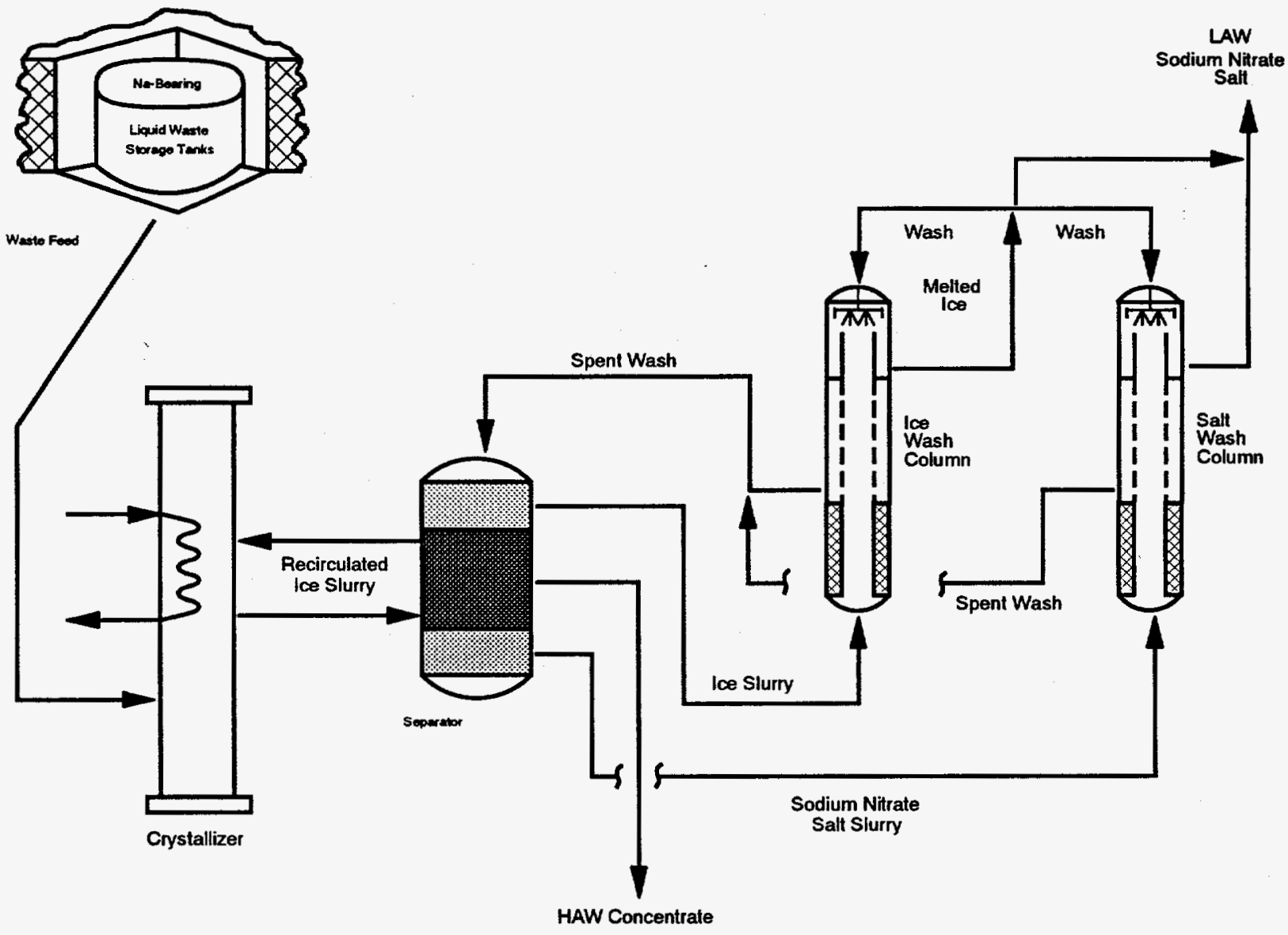

Figure 6. Freeze Crystallization Process Diagram 
Direct contact crystallization using liquid nitrogen was initially determined to be the most favorable for application to treatment of the sodium-bearing waste. Computer modeling has indicated that a large fraction of the water content and up to $70 \%$ of the sodium can be removed from the liquid waste solution using this technology. The water will be removed as pure ice crystals, while the sodium will be removed from the radionuclide-contaminated solution as sodium nitrate precipitate.

Four major components are required. The crystallizer vessel is the location where liquid nitrogen is injected and ice formation occurs. The salt growth vessel provides sufficient residence time is allowed for the sodium nitrate crystal to grow. The ice wash column separates from the concentrated solution and washed with clean water. The salt wash column separates sodium nitrate salt the concentrated solution and washes it with water saturated with sodium nitrate.

\section{Assumptions Used in Completing Mass Balance Calculations}

- Freeze crystallization (FC) results in three effluent streams: 1) a pure ice crystal stream which is later melted to liquid water; 2) a solid precipitate stream consisting of sodium nitrate crystals; and 3) a concentrated liquid stream consisting of all the original sodiumbearing waste (SBW) components minus the water and sodium nitrate streams.

- Two weight percent of the components in the feed stream (except water and sodium) will reside in the sodium nitrate precipitate as occlusions. To achieve Class $\mathrm{A}$ waste, two cycles of FC will be used. The precipitate from the first cycle will be dissolved in pure water to make an $\mathrm{Na}$ concentrate and then reprecipitated; this will result in a final precipitate phase having $0.07 \mathrm{wt} \%$ of the feed stream components (except for water and sodium). The liquor from the second cycle will be concentrated to achieve an $\mathrm{Na}$ concentration greater than the original feed, then be combined back into the original feed stream.

- Water removal of $77 \mathrm{wt} \%$, via ice, results for the freeze crystallization process in each cycle. The water removed from the second cycle liquor is recycled and used to dissolve the precipitate from the first cycle.

- Na removal of $64 \mathrm{wt} \%$ is achieved as $\mathrm{NaNO}_{3}$ precipitate for freeze crystallization in each cycle.

- The refrigerant is liquid or two-phase nitrogen $\left(\mathrm{N}_{2}\right)$. Although this is a process additive, no secondary waste results from its use. Therefore, $\mathrm{N}_{2}$ is not considered in the volume or mass calculations.

- Ice crystal wash water is recycled and eventually evaporated. Therefore, no additional low activity waste (LAW) volume is assumed to be attributed from this wash. 
- Tritium will partition the same as the water.

\section{MAJOR DEVELOPMENT ISSUES}

Tests are needed to determine the process efficiency as well as to elucidate the process thermodynamics and precipitation rates.

Direct and indirect contact freeze crystallization systems share some common development challenges such as; scale-up of the development process to a production scale facility, operating and maintaining the process remotely, and handling the resulting precipitated solids.

The direct contact method has presented challenges in being able to prevent the refrigerant nozzle from freezing. While the indirect contact system has not encountered this freeze-up problem, corrosion of the heat transfer surface is a concern. Therefore, research and selection of materials is crucial.

\section{NEUTRALIZATION/PRECIPITATION}

In the wastewater treatment industry, by far the most widely used process for removal of heavy metals from solution is that of chemical precipitation. The most commonly used precipitation technique is hydroxide treatment due to its relative simplicity, low cost of precipitant, and ease of automatic $\mathrm{pH}$ control. The solubilities of the various metal hydroxides are minimized for a solution $\mathrm{pH}$ in the range of 7 to 11. A proposed sodium-bearing waste (SBW) treatment process by hydroxide precipitation of the polyvalent cations and actinides is shown in Figure 7.

Nearly all of the polyvalent cations can be rejected from SBW by neutralizing the excess acid with $\mathrm{NaOH}$ and raising the $\mathrm{pH}$ to 8-10. This results in a sludge containing the TRU, toxic metals, and a large fraction of the strontium with the inert polyvalent cationic precipitates. The precipitate would be separated from the salt solutions by filtration or centrifugation. SBW contains more than $17000 \mathrm{ppm}$ of $\mathrm{Al}$ and the aluminum hydroxide characteristically forms a gelatinous precipitate that is difficult to separate from supernate solution. A flocculating agent will be needed to improve dewatering operations. Following filtration, the precipitate cakes can be directly vitrified, or used as a sodium additive for the glass ceramic process after it has been thermally dried. The precipitate may require washing to remove residual sodium; subsequently, the precipitate can be redissolved and calcined in the ICPP calciner. Due to the large quantity of various polyvalent metals in the SBW, more than one $\mathrm{pH}$ treatment may be required to produce satisfactory - insolubility for each of the metal ions and actinides present in the waste solution. 


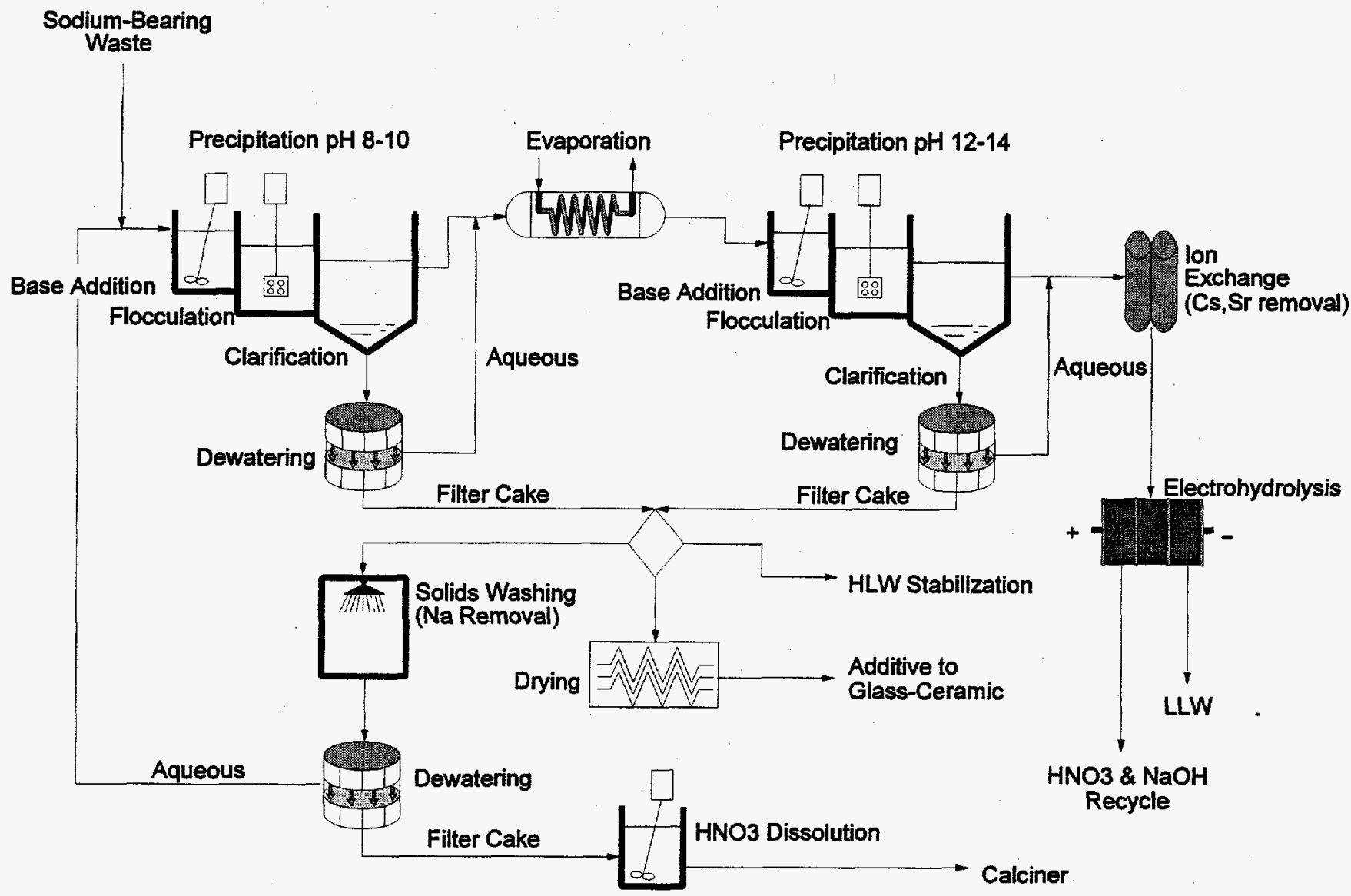

Figure 7. Neutralization/Precipitation Process

The liquid supernate contains most of the alkali metals and less than $5 \%$ of the polyvalent metals; therefore, further separation of $\mathrm{Sr}$ and $\mathrm{Cs}$ from the supernate may be required to produce a Class B or Class A LLW. In order to reduce the amount of precipitating agent that is used, electrohydrolysis $(\mathrm{EH})$ is being considered to recover and recycle the alkali hydroxides.

\section{Assumptions Used in Completing Mass Balance Calculations}

- Neutralization of the sodium-bearing waste (SBW) produces two phases (a solid and a liquid phase). If the precipitate will be directly made into a glass, sodium hydroxide will be added to achieve a supernate having a $\mathrm{pH}$ of 13.5. Otherwise, a $\mathrm{pH}$ of 11 will be achieved to maximize aluminum precipitation. 
- No significant change of total volume (high activity waste (HAW) plus LAW) results; $95 \%$ of the water $\left(\mathrm{H}_{2} \mathrm{O}\right)$ stays in the LAW liquid stream and $5 \%$ with the HAW solid product. $100 \%$ solid/liquid separation is assumed.

- The assumed component removal percentages are listed in Table 13.

- Fresh acid or the nitric acid from electrohydrolysis will be used to redissolve the precipitate prior to waste immobilization. Sufficient acid will be used to provide a redissolved HAW with a $1.6 \mathrm{M} \mathrm{Al}$ and $1.0 \mathrm{M} \mathrm{H}^{+}$concentration. If the desired immobilized product is a HAW glass, the precipitate would not be redissolved with nitric acid since direct vitrification would be possible.

Note, that even though $\mathrm{NaOH}$ is recycled when electrohydrolysis is an operating option, the $\mathrm{NaOH}$ will eventually be immobilized as LAW.

\section{MAJOR DEVELOPMENT ISSUES}

The optimum process conditions must be determined for different feed compositions.

The ability to control the $\mathrm{pH}$ for high ionic strength solutions, especially for radioactive SBW solutions must be determined.

A method of dewatering the gelatinous precipitate must be developed.

Remote-operated filtration equipment to achieve maximum liquid-solid separation with minimum secondary waste generated must be selected.

The effects of hydroxide precipitate aging must be determined.

In Table 13 the assumed component precipitation removal percentages are listed. 
Table 13. Assumed Precipitation Removal Percentages

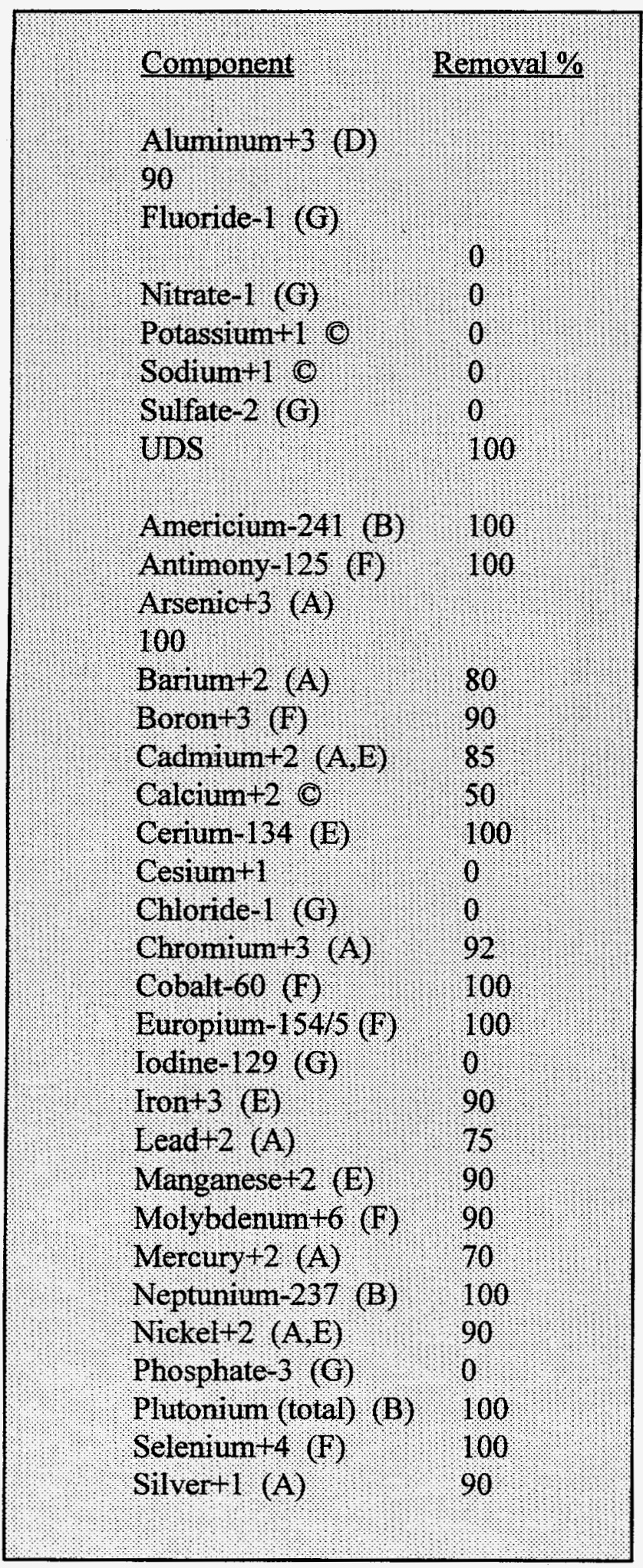

\section{References}

A) R. W. Peters, Y. Ku, and D. Bhattacharyya, "Evaluation of Recent Treatment Techniques for Removal of Heavy Metals from Industrial Waste Waters," AIChE Symposium Series: Separation of Heavy Metals and Other Trace Contaminants, 81 (243), pp. 165-203, 1985.

B) N. A. Chipman, G. O. Engelgau, and J. R. Berreth, "An Evaluation of Alternative Methods for Processing Sodium-Bearing Waste," WIN-268, 1989.

C) R. H. Perry and C. H. Chilton, eds., Chemical Engineers' Handbook, McGraw-Hill Book Co., New York, 1973.

D) Personal Communication, J. A. Nenni, September 28, 1993.

E) W. B. Kerr, "Studies on the Removal of Inerts from ICPP HLLW by Neutralization," WIN-168, 1985.

F) Estimation based on chemical similarity to other ions with published removal efficiency.

G) Removal of anions was based on the assumption that all cations would precipitate as hydroxide salts.

H) Tritium would be contained in the water stream due to the chemical similarities between tritiated water and water. 


\section{ELECTROHYDROLYSIS}

Electrohydrolysis $(\mathrm{EH})$ involves the union of two broad technologies; electrolysis and membrane separation. It is characterized by the use of ion-selective membranes and an electric field orthogonal to the membranes. In general, an EH unit, or cell stack, consists of anion-selective, cation-selective, and bipolar membranes placed alternately between an anode and a cathode, as shown in Figure 8. The electromotive force produced by the electric field causes ions produced in the solution to pass through the membranes. Anion-selective membranes will only allow anions and water molecules to pass. Cation-selective membranes, likewise, will only allow passage of cations and water molecules. Bipolar membranes, which are an anion-selective and a cation-selective membrane fused together, allow water molecules to pass between the two membranes. While inside the membrane, the influence of the electric field causes the water molecules to be split into hydronium ions $\left(\mathrm{H}_{3} \mathrm{O}^{+}\right)$and hydroxide ions $\left(\mathrm{OH}^{-}\right)$. The following equilibrium reaction describes this water dissociation:

$$
2 \mathrm{H}_{2} \mathrm{O} \rightleftharpoons \mathrm{H}_{3} \mathrm{O}^{+}+\mathrm{OH}^{-}
$$

\section{Electrohydrolysis}

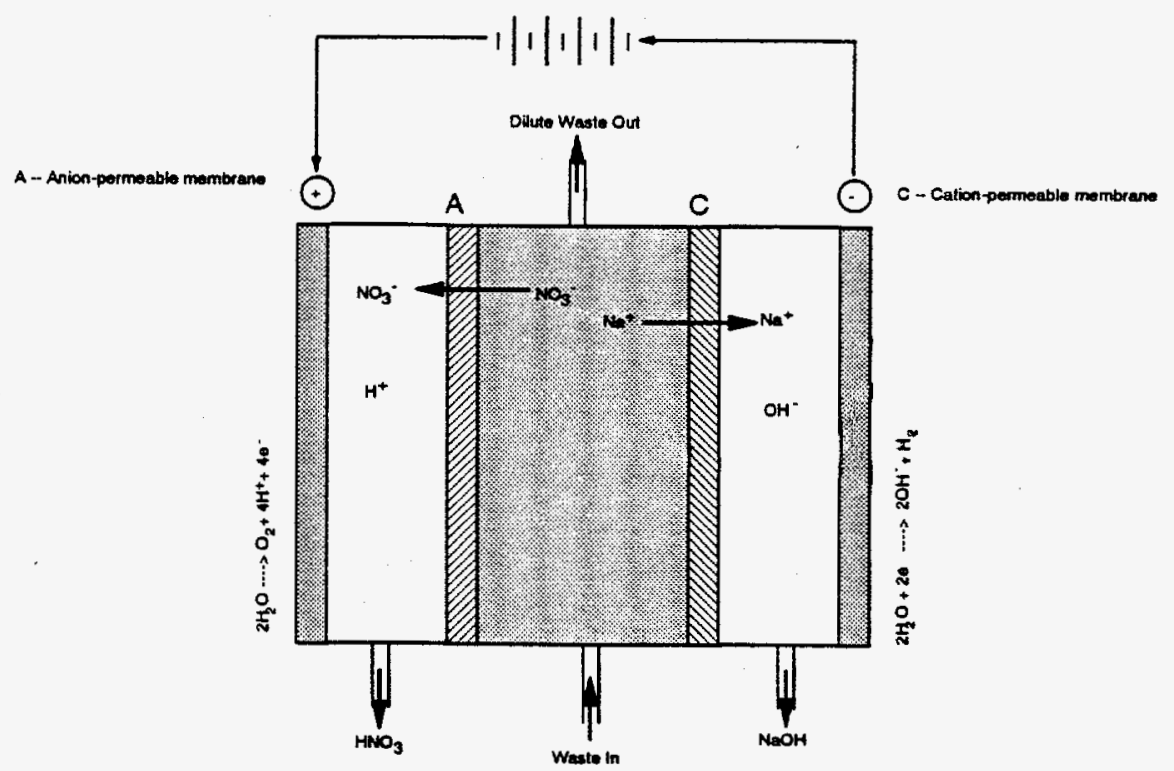

Figure 8. Electrohydrolysis Process

The hydronium and the hydroxide ions then pass through the cation-selective and anion-selective sides of the bipolar membrane, respectively. It is the action of the bipolar membrane that distinguishes EH from electrodialysis. Once in the bulk solution, the hydronium ions combine with the anions $\left(\mathrm{A}^{-}\right)$in solution to form an acid by the following reaction:

$$
\mathrm{H}_{3} \mathrm{O}^{+}+\mathrm{A}^{-} \rightleftharpoons \mathrm{HA}+\mathrm{H}_{2} \mathrm{O}
$$


The hydroxide ions combine with the cations $\left(\mathrm{C}^{+}\right)$in solution to form a base by the following reaction:

$$
\mathrm{OH}^{-}+\mathrm{C}^{+} \rightleftharpoons \mathrm{COH}
$$

As a result, concentration occurs in the compartments where the weak acid and where the weak base is added (see Figure 8) while dilution occurs in the compartment where the waste is added.

In the compartment adjacent to the anode, hydrogen ions combine to form hydrogen gas. Evolution of this gas is prevented by the introduction of an electrode rinse. Similarly, in the compartment adjacent to the cathode, oxygen gas is formed which is simultaneously removed by an electrode rinse.

\section{Assumptions Used in Completing Mass Balance Calculations}

- Electrohydrolysis (EH) results in three effluent streams:

1) an $\mathrm{HNO}_{3}$ stream;

2) an $\mathrm{NaOH}$ stream; and

3) a dilute waste stream.

- $\quad \mathrm{The}^{+}{ }^{+}$and $\mathrm{NO}_{3}{ }^{-}$is formed into $\mathrm{NaOH}$ and $\mathrm{HNO}_{3}$ via electrolysis of the water by the following reactions:

$$
\begin{array}{ll}
2 \mathrm{H}_{2} \mathrm{O}--->\mathrm{O}_{2} \uparrow+4 \mathrm{H}^{+}+4 \mathrm{e}^{-} & \text {Anode Reaction } \\
2 \mathrm{H}_{2} \mathrm{O}+2 \mathrm{e}^{-}-->>2 \mathrm{OH}^{-}+\mathrm{H}_{2} \uparrow & \text { Cathode Reaction }
\end{array}
$$

The amount will just be that $\mathrm{NaOH}$ quantity which is required to serve the requirements of other operations such as neutralization.

- $95 \mathrm{~mole} \%$ of the anions transfer across the membrane and leave with the $\mathrm{HNO}_{3}$ stream. $5 \mathrm{~mole} \%$ of the anions remain in the dilute waste stream.

- $95 \mathrm{~mole} \%$ of the cations transfer across the membrane and leave with the $\mathrm{NaOH}$ stream. $5 \mathrm{~mole} \%$ of the cations remain in the dilute waste stream.

- Of the water $\left(\mathrm{H}_{2} \mathrm{O}\right)$ remaining that is unsplit, $25 \mathrm{wt} \%$ leaves with the $\mathrm{HNO}_{3}$ stream, 25 wt\% leaves with the $\mathrm{NaOH}$ stream, and $50 \mathrm{wt} \%$ remains in the dilute waste stream.

\section{DEVELOPMENT REOUIREMENTS}

Development requirements for $\mathrm{EH}$ are different depending on the process feed stream. In any case a radioactive demonstration of the equipment is required. If the feed stream is a sodium nitrate solution from either crown ether extraction of sodium or freeze crystallization, 
development activities will center on equipment since this application of $\mathrm{EH}$ has been proven in industry.

However, if the feed stream is the supernate stream from precipitation by neutralization, some chemistry development is required due to the composition of the feed. Since precipitation does not remove all of the divalent cations (i.e., calcium, strontium, etc.), they must either be removed prior to introduction to the EH cell stack, or special membranes that will not allow these cations to enter the base production cells must be used. If the divalent cations are allowed to enter the base production cells, they will combine with the hydroxide ions and form insoluble hydroxide compounds that will foul the membranes. Therefore, this shortcoming must be addressed to make $\mathrm{EH}$ a viable addition to processing sodium-bearing waste by precipitation.

\section{ACTINIDE REMOVAL}

Actinide removal consists of a continuous counter-current solvent extraction process. A process schematic is shown in Figure 9. For this analysis the TRUEX solvent is assumed to be used to partition the actinides from aqueous acidic feed stream. It typically consists of $0.2 \mathrm{M}$ CMPO (octylphenyl-N,N-diisobutylcarbamoylmethyl-phosphine oxide), and 1.4 $\underline{\mathrm{M}} \mathrm{TBP}$ (tributyl

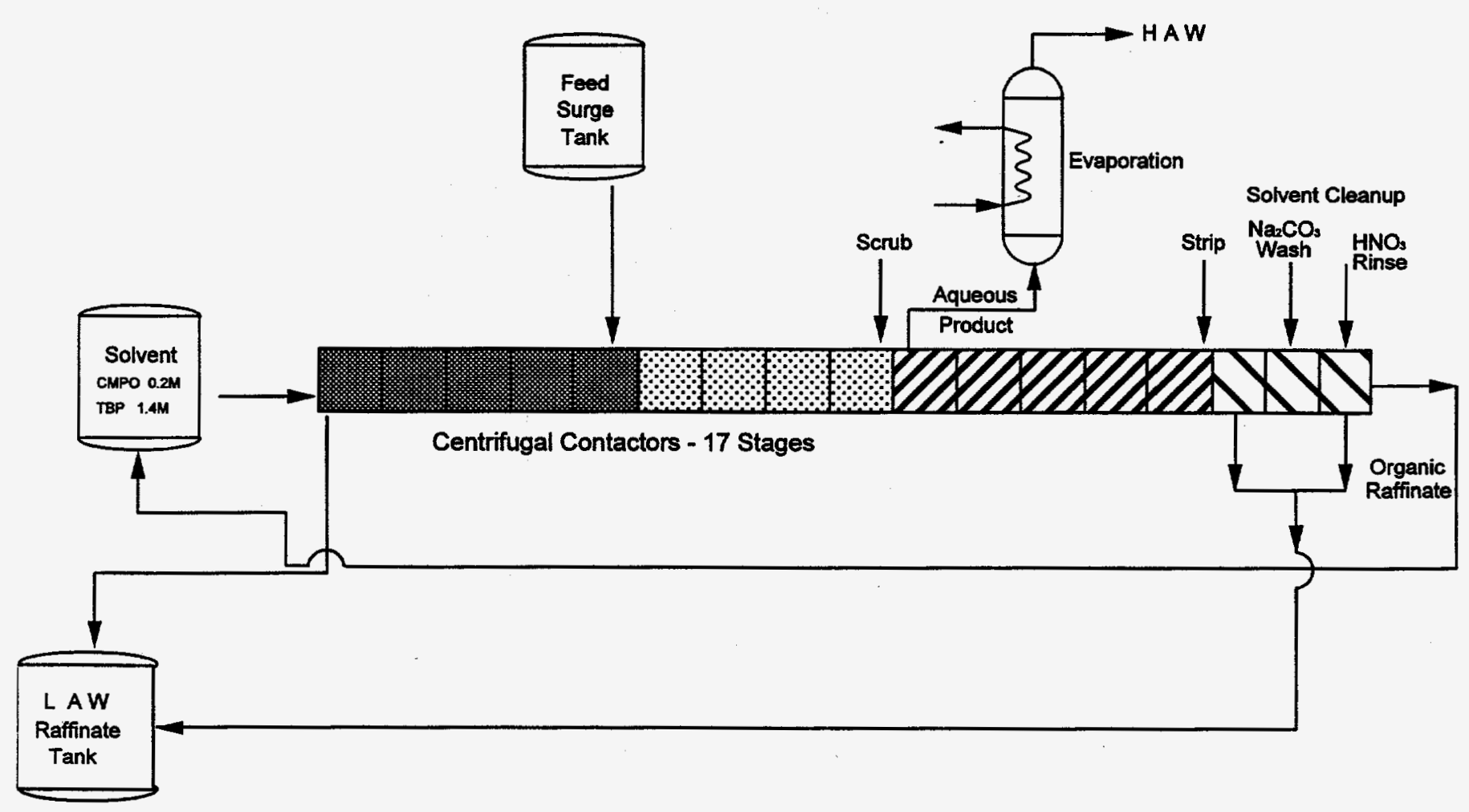

Figure 9. Actinide Removal Process 
phosphate) in a branch chain hydrocarbon, Isopar-L. The process includes an extraction section where the actinides are partitioned into the organic solvent, a scrub section where the organic solvent is washed with nitric acid to transfer some components which are not desired to be extracted back into the aqueous phase, strip section where the partitioned actinides are transferred back to an aqueous phase, and a solvent wash section where the stripped solvent is washed with sodium carbonate to remove degradation products from the solvent and prepare it to be recycled back to the extraction section.

\section{Assumptions Used in Completing Mass Balance Calculations}

- TRUEX process technology will be utilized. The waste feed composition is entered into the Generic TRUEX Model (GTM) software; the components not considered in the model are assumed to not extract but reside in the raffinate.

- It is assumed that ammonium oxalate will be used as the strip solution and nitric acid will be used as the scrub solution.

Five extraction stages, four scrub stages, five strip stages, and a total of three organic wash stages using three different feed streams are modeled. The compositions are $0.2 \mathrm{M}$ nitric acid for the scrub, $0.1 \mathrm{M}$ oxalate for the strip, $0.25 \mathrm{M}$ sodium carbonate for the first wash, and $0.1 \mathrm{M}$ nitric acid for the second wash. The extraction has an aqueous to organic volume ratio of 3:1 and strip aqueous to organic volume ratio of 5:3.

- The most probable valence state of $\mathrm{Pu}(+4)$ was chosen for extraction due to the oxidizing environment.

- All feed stream components not included in the GTM are assumed to not extract; they will reside in the raffinate or LAW. A component distribution of greater than $99.9 \%$ is considered $100 \%$.

- The HAW stream containing the extraction products is concentrated to provide a nitrate concentration of $6 \underline{\mathrm{M}}$ in the resulting solution.

- The raffinate and organic wash streams will combine into one LAW stream.

The organic will be recycled and, at the end of operations, incinerated at a waste treatment facility.

\section{MAJOR DEVELOPMENT ISSUES}

Major development is continuing in the areas of determining alternative strip solutions, zirconium behavior in the process, performing counter current tests for flowsheet verification, 
and refining operating parameters to determine the effects of feed stream compositional changes, number of stages required, solvent to aqueous flow ratios, and temperature effects.

\section{STRONTIUM REMOVAL}

The removal of ${ }^{90} \mathrm{Sr}$ from sodium-bearing waste and dissolved calcine solutions is assumed to be accomplished by a continuous countercurrent solvent extraction process which uses variations of a crown ether (18-crown-6) as a strontium specific extractant. A process schematic is shown in Figure 10. The organic diluent may consist of either 1-octanol or a tributyl phosphate/Isopar-L mixture. The process would use centrifugal contactors and supporting equipment similar to the Actinide removal process. This system has been developed extensively at Argonne National Laboratories and has been designated SREX ( StRontium EXtraction). The ${ }^{90} \mathrm{Sr}$ is extracted by 18-crown-6 in the presence of high acid concentrations and stripped in the presence of dilute nitric acid.

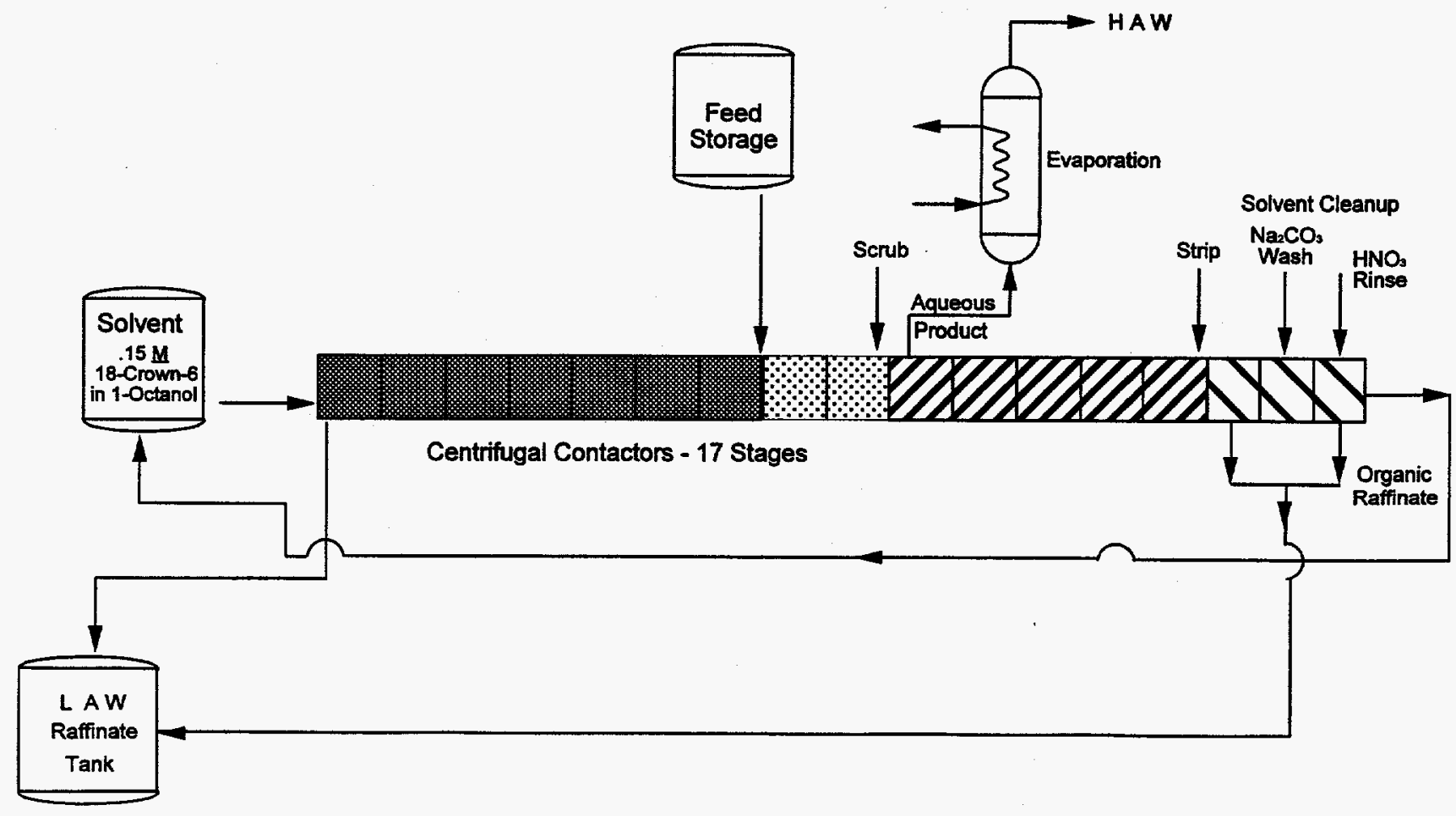

Figure 10. Strontium Removal Process 
The solvent may be recycled for repeated cycles of extraction. There are two variations of 18crown-6 which may be used for ${ }^{90} \mathrm{Sr}$ removal; Dicyclohexano-18-crown-6 which is currently available as a high purity reagent in kilogram quantities and $4^{\prime}, 4^{\prime},\left(5^{\prime}\right)$-di-(t-butyldicyclohexo)-18crown- 6 which is a variation of the first chemical and is currently available in kilogram quantities.

\section{Assumptions Used in Completing Mass Balance Calculations}

- The Strontium extraction (SREX) process utilizes $4^{\prime}, 4^{\prime}\left(5^{\prime}\right)$-di-tertbutyldicyclohexo)-18crown-6 as a Sr extractant in either 1-octanol or 1.2 M TBP/Isopar L.

- The organic will be recycled and, at the end of operations, incinerated at a waste treatment facility.

$99.7 \%$ of the $\mathrm{Sr}$ and equal molar amounts of $\mathrm{K}$ and $\mathrm{Na}$ are removed per process cycle in sodium-bearing wastes. Higher distribution coefficients are attained in dissolved calcine solutions which allow a decontamination factor of $10^{6}(99.9999 \%$ removal) for $\mathrm{Sr}$ in one process cycle. However, a value of $99.7 \%$ removal per process cycle has been used for all calculations to provide a conservative result.

\section{MAJOR DEVELOPMENT ISSUES}

The long-term performance of the SREX solvent in high acid, highly radioactive environments have not been thoroughly investigated. Thermolytic and radiolytic degradation of the process solvent may require additional solvent clean-up processes or periodic replacement of the process solvent.

The 18-crown-6 extractants used in the SREX process have a small solubility in aqueous solutions. This presents the possibility of trace amounts of the extractant in the final waste form. The possible effects on the waste form, if any, are currently unknown.

The fate of hazardous metals in the SREX process has not been thoroughly investigated. Lead is known to be extracted by the solvent. Mercury and cadmium are not expected to be extracted. However, a detailed investigation of non-radioactive hazardous metals extraction is necessary.

The presence of large concentrations of potassium in sodium bearing waste results in some extraction of potassium in the solvent. Although the potassium may be able to be scrubbed from the solvent, the effect of a small amount of potassium in the final waste form should be evaluated. 


\section{CESIUM REMOVAL}

Fixed-bed sorption processes such as ion exchange are useful treatment methods for separating and recovering chemical species of interest; the element $\mathrm{Cs}$ in this case. The fixed bed consists of a solid, insoluble material which is capable of entering into chemical reactions with ionized chemical species in solution. A liquid solution is passed through the bed and the chemical species in the solution react with, or adsorb onto, the solid material. The solution passes through and the material of interest is effectively removed. Cesium removal technologies have been relatively well characterized for alkaline solutions. The technologies are not as well developed for acidic solutions. Several ion exchangers have been suggested for use in acidic solutions; however, ammonium molybdophosphate (AMP) using modified polyacrylonitrile (PAN) as a binder appears to be a satisfactory selection at this time. A process schematic is shown in Figure 11.

Liquid feed would be introduced to a vessel containing a fixed bed of AMP-PAN where sorptive mass transfer between $C s$ ions in the liquid and the active surface of the solid would occur. Once the bed is saturated with $\mathrm{Cs}$, the column would be eluted to remove the Cs and regenerated for reuse, or the resin would be removed and replaced with fresh resin. The spent resin, in any case, will require processing for final disposal as a LLW or HLW. If the AMP-PAN can be eluted and regenerated, the quantity of waste material will be significantly reduced.

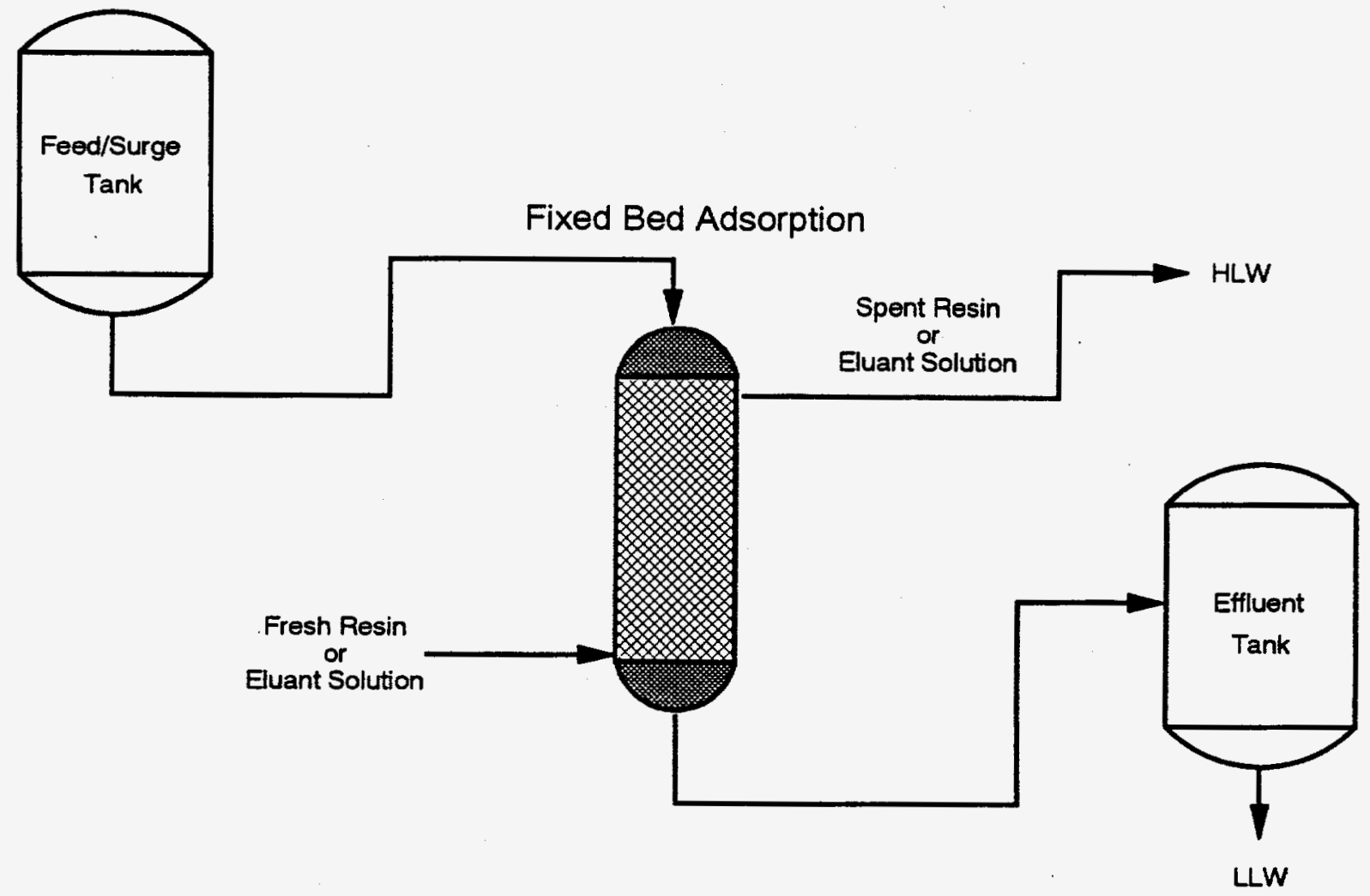

Figure 11. Process for Cs Removal by Fixed Bed Sorption 


\section{Assumptions Used in Completing Mass Balance Calculations}

Cesium sorption onto sorbent materials is characterized by two parameters. The first parameter concerns the physical and/or theoretical capacity of the material at saturation (i.e., how much cesium can it hold). The capacities are usually reported in terms of the number of grams of cesium sorbed per kilogram of sorbent. The second parameter is a mass transfer coefficient that quantifies the amount of cesium sorbed when in equilibrium with the contacting solution. From the mass transfer coefficient and the capacity, one can estimate the cesium concentration where the material becomes saturated and bed breakthrough curves. Material saturation is not normally achieved because the aqueous cesium concentrations are well below the value where the saturation is approached. Typical operation of a sorbent column involves the termination of the process when a given breakthrough (discharge) cesium concentration is reached.

- The assumed engineered sorbent form is ammonium molybdophosphate (AMP) on a polyacrylonitrile (PAN) support. Sorbent loading in the engineered form is $80 \mathrm{wt} \%$ for AMP.

- $\quad$ Breakthrough sorbent capacity for AMP is 9.3g Cs per $\mathrm{kg}$ of AMP. This is a conservative number based on tests performed at ICPP, but is prudent until further testing can be accomplished.

- At this point it is planned that spent sorbents will not be regenerated. They will be incorporated into a HAW glass or glass-ceramic. It is not presently known how the spent resin will behave during the immobilization process because of its organic composition, but the organic portion is expected to volatilize and be carried with the offgas. Testing is being performed to elute the adsorbed Cs and literature suggests that it will be feasible. If elution tests are successful, the spent resin must still be disposed of, but probably not as HAW.

\section{MAJOR DEVELOPMENT ISSUES}

AMP-PAN has been proven very effective for removing cesium in batch contacts. It still needs to be scaled-up into an actual column operation. Operational and design parameters, such as maximum flow rates, bed depths, temperatures, pressure drops, and usable capacities need to be determined.

Techniques for eluting the cesium from the resin need to be addressed. If elution is not possible, techniques for dissolving the resin would need to be addressed.

Development needed is in the area of suitable inorganic supports that will maintain high selectivity and good physical properties while being more desirable for the final glass form. 


\section{CEMENTATIONIGROUTING}

Cementation/grouting technology refers to the process of encapsulating and/or stabilizing a waste material in a fluidal or molten material which can be pumped (or grouted) into a container where the material solidifies. Viable grouting options include cements, thermoplastic polymers, and thermosetting polymers. Examples of cements are hydraulic cements (Portland, gypsum, etc.) and phosphate-bonded calcium aluminate (PBCAC). Examples of thermoplastic polymers are bitumen, sulfur cement, and polyethylene. Examples of thermosetting polymers are vinyl-esterstyrene, polyester resins, and epoxy resins.

Type I Portland cement was selected to stabilize the high sodium containing wastes at the ICPP. It appears that high-temperature calcination is required to reduce all of the nitrates in the wastes to an oxide form. The addition of silica or clay during thermal denitration may help form insoluble, leach resistant sodium-alumina-silicates. It is expected that it will be possible to reach high waste loadings, perhaps as high as $70 \%$ waste loading, by implementing such waste conditioning measures. The key to controlling product consistency is selecting the most appropriate mixing process and carefully controlling the mixing of cement ingredients. Processes for mixing the waste with cement can be divided into three categories: batch mixing, in-line mixing, and in-container mixing. Each process has its virtues and vices. Batch mixing involves the addition of the waste, cement, and additives to a large mixing vessel. A schematic of one batch mixer is shown in Figure 12. After achieving a homogeneous mixture, the grout is transferred to drums.

In-line mixing involves continuous mixing of the waste, cement, and additives with the mixture being continuously fed to the grout containers as illustrated for one example in Figure 13.

In-container mixing involves mixing the waste and cement inside the drums by either a tumbling action or a stirrer as depicted by the schematics in Figure 14. Generally, the mixing weight is disposed with the waste, while the stirrer may be either disposable or reusable. 


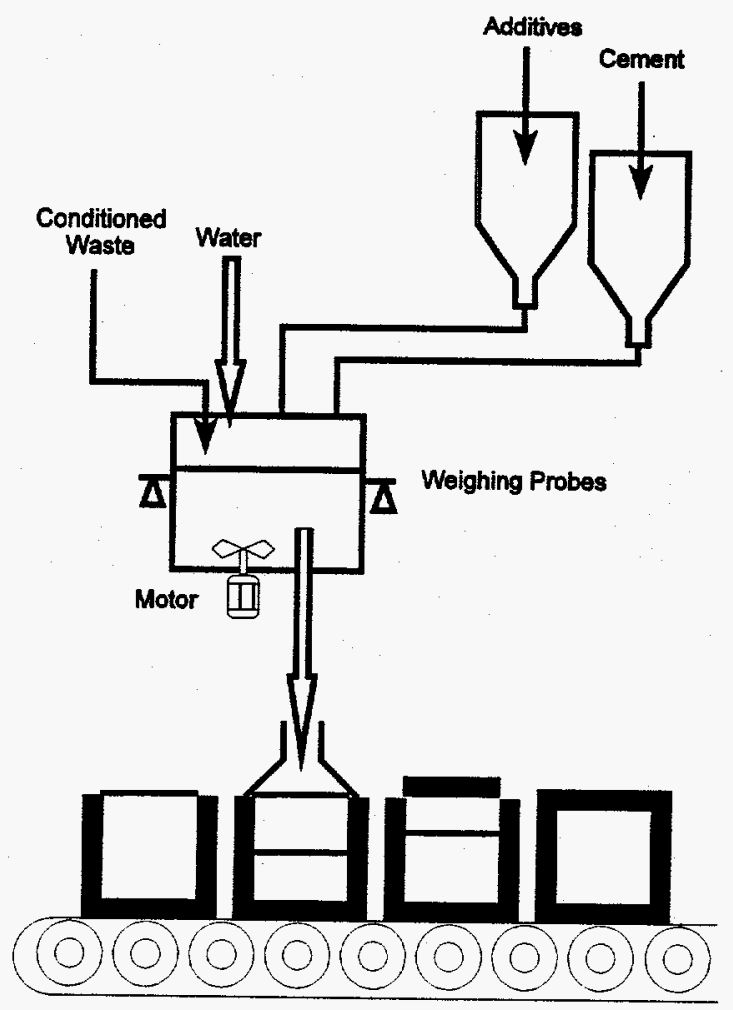

Figure 12. Batch Mixing Grout Process

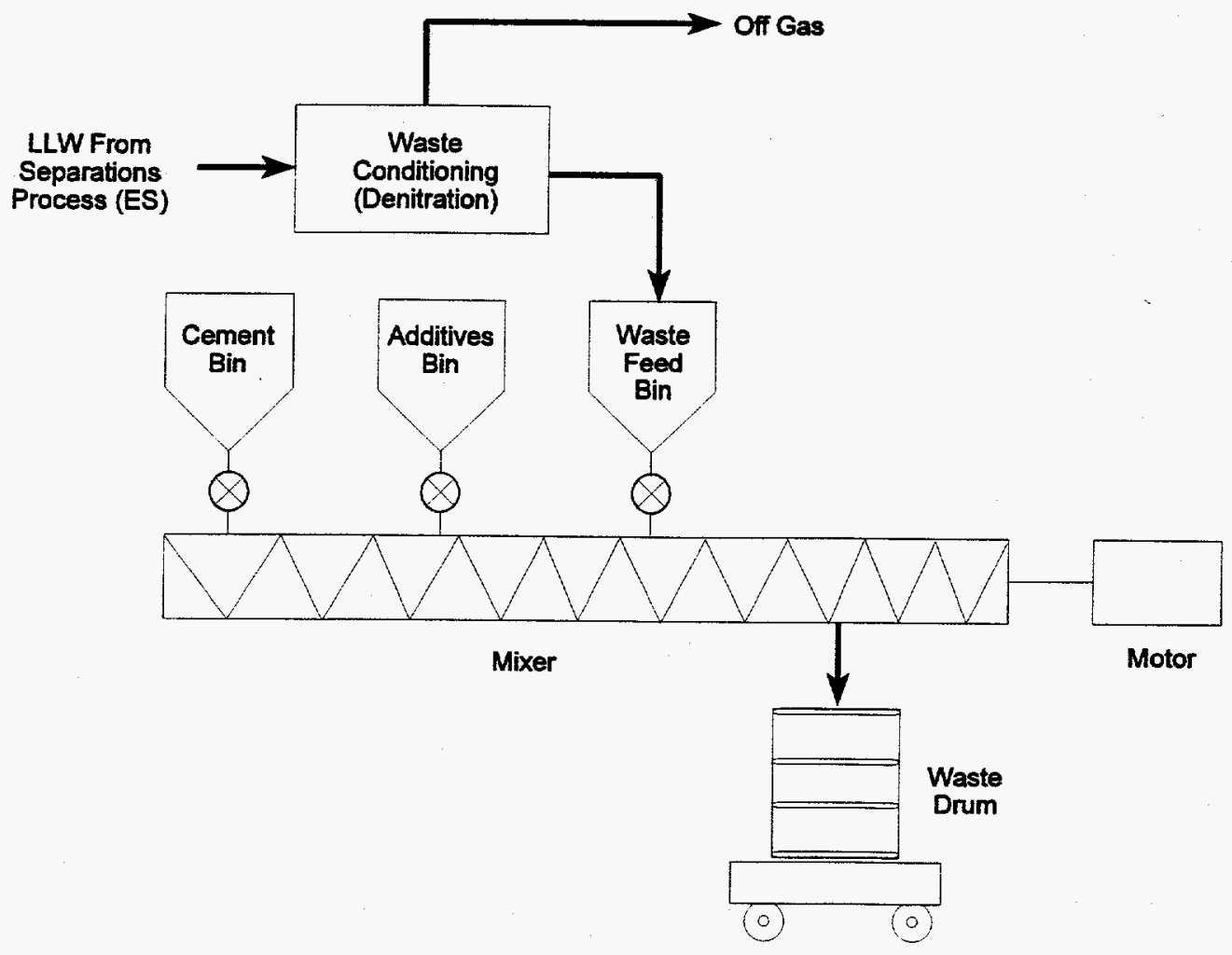

Figure 13. In-Line Grout Process 


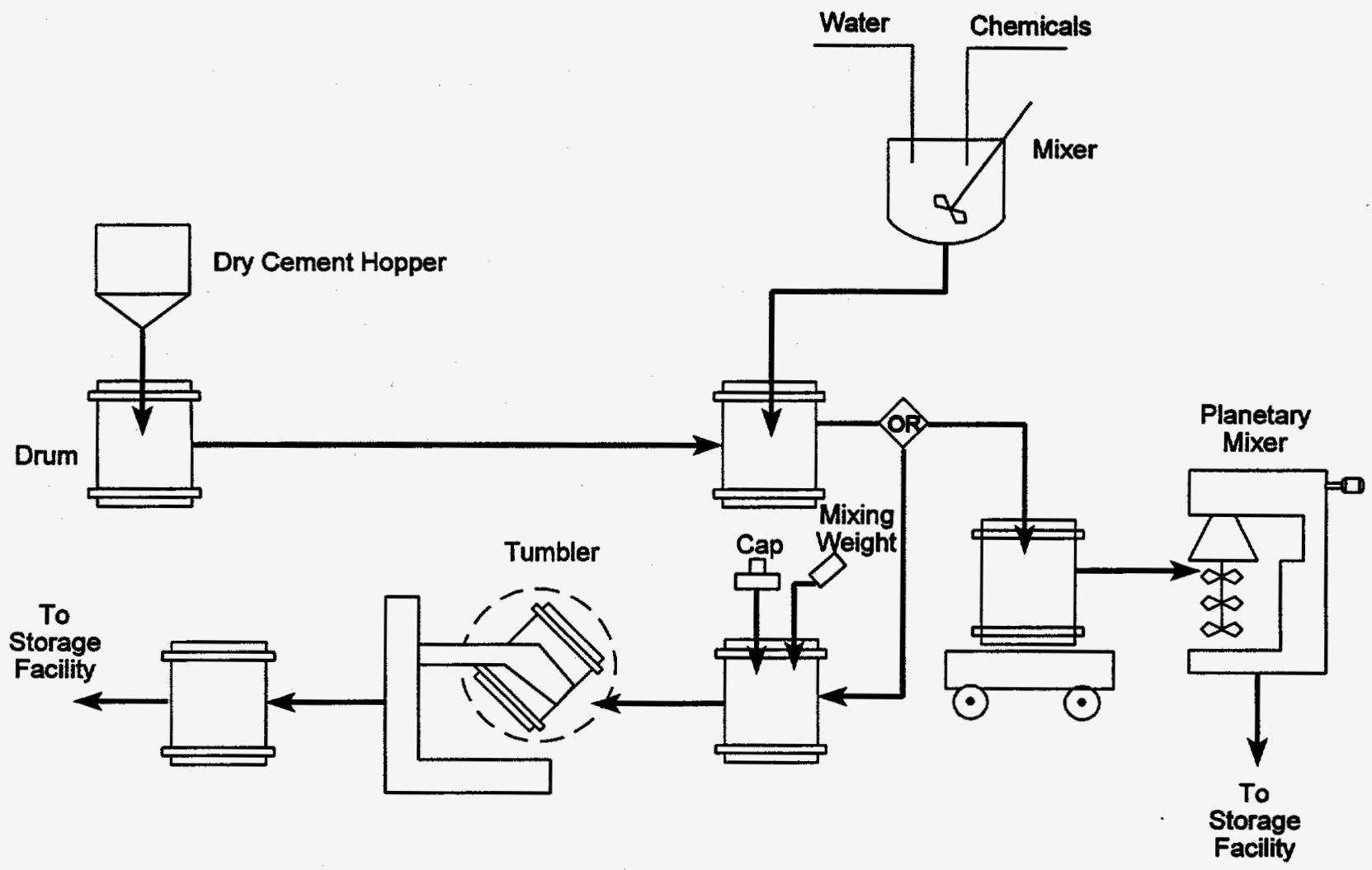

Figure 14. In-Container Grout Process

\section{Assumptions Used in Completing Mass Balance Calculations}

- The calculations assume excess water is evaporated off and a waste loading of $25 \%$, with a corresponding decrease in the weight of sand, will be used as suggested in Table 14 on the following page.

- The assumed grout density will be $2.0 \mathrm{~g} / \mathrm{cm}^{3}$.

\section{MAJOR DEVELOPMENT ISSUES}

A conceptual design for a grout pilot plant is being completed. The advent of improved in-line mixers and also a double planetary mixer for in-container mixing are considered likely candidates for the design. An evaluation of the mixing options will be made to select the most favorable option for the ICPP streams.

The pilot plant also includes the specification of equipment to dry, denitrate, and calcine the waste. The ICPP $30-\mathrm{cm}$ calciner pilot plant is being evaluated for this purpose. Alternatively, a wiped-film evaporator, followed by a kneader dryer or a rotary kiln, is being considered for this function. 
Other parameters currently under investigation include the optimum water-to-cement ratio (w/c) which is probably the most significant single parameter affecting the strength and chemical resistance of a hardened cement mix. Results to date show that a $10 \%$ waste loading passes initial strength and leach resistance criteria at a w/c of around 0.5 .

Table 14. Reference Grout Formula

\begin{tabular}{|r|l|l||}
\hline Wt \% & \multicolumn{1}{|c|}{ Component } & \multicolumn{1}{c|}{ Comments } \\
\hline 22.0 & Cement & $\begin{array}{l}\text { Cement/fly ash ratio is adjustable, for } \\
\text { maximization of compressive strength and } \\
\text { minimization of strontium leaching }\end{array}$ \\
\hline 11.0 & Fly ash & Illitic clay, to minimize cesium leaching \\
\hline 7.5 & Clay & $\begin{array}{l}\text { To improve the thermal conductivity and strength } \\
\text { of the solidified product }\end{array}$ \\
\hline 27.75 & Sand & $\begin{array}{l}\text { Can be increased to 25 wt\%, with a decrease in } \\
\text { sand }\end{array}$ \\
\hline 15.0 & Waste Solids & For processability and hydration \\
\hline 15.0 & Water & Can be increased \\
\hline 0.75 & Nitrate $\left(\mathrm{NaNO}_{3}\right)$ & $\begin{array}{l}\text { D-65, from Dowell, to minimize the amount of } \\
\text { water, needed for a pourable grout }\end{array}$ \\
\hline 1.0 & Water reducer &
\end{tabular}

Note: This is a grout reference formula taken from Radioactive Waste Forms for the Future, Werner Lutze and Rodney C. Ewing, Editors, North-Holland, 1988. It is formulated under elevated temperature and pressure and is called FUETAP grout. 


\section{GLASS (VITRIFICATION)}

Vitrification involves combining a liquid or solid waste material with a glass-forming frit (typically $\mathrm{SiO}_{2}, \mathrm{~B}_{2} \mathrm{O}_{3}$, and $\mathrm{Na}_{2} \mathrm{O}$ ) at high temperatures $\left(1050\right.$ to $1200^{\circ} \mathrm{C}$ ) to produce a glass. A schematic diagram of the HLW vitrification process envisioned for the ICPP is shown in Figure 12. There are two possible feeds to the process; liquid and calcine. Liquid feed to the process would be either sodium waste or a solution containing the actinides and fission products resulting from a separations process. In the case of liquid feed, the process would be envisioned as follows. The HLW liquid would be sampled and analyzed. Next, based on the analytical results, a suitable frit composition and waste loading would be selected. Finally, the liquid could be dried in a rotary calciner or blended directly with frit and introduced to the glass melter.

As seen in Figure 15, the process for a calcine may be described as follows. Calcine would be retrieved from the bin sets and transported to a calcine/calcine blender where the calcine would be blended, sampled, and analyzed. Based on the results of the analysis, a suitable frit and waste

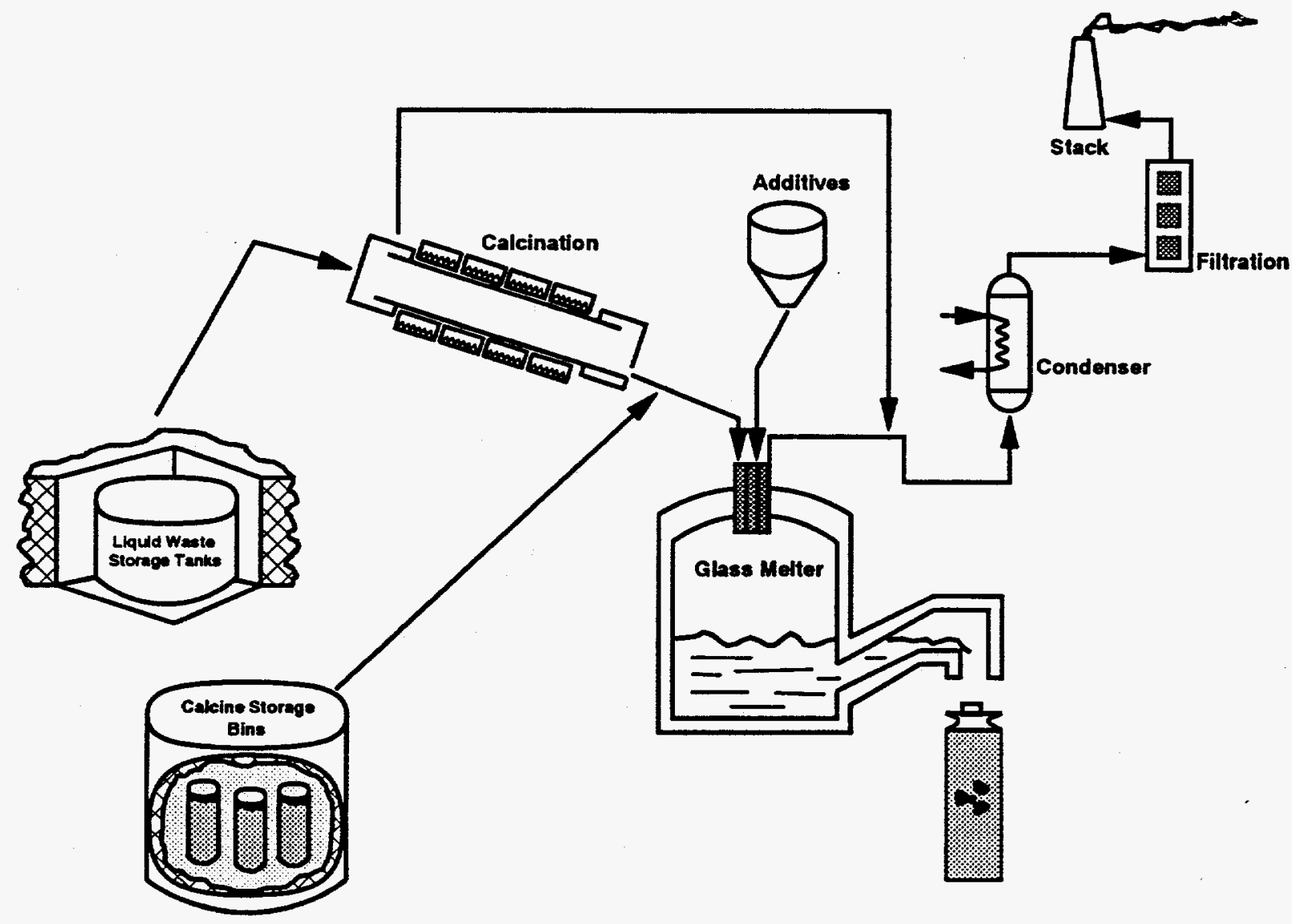

Figure 15. Vitrification (Glass) Process 
loading would be selected. Next, frit and calcine would be added to the glass melter in the required proportions. Typical calcine waste loadings in the glass vary from 25 to $33 \mathrm{wt} \%$ depending on the type of calcine to be vitrified.

The glass melter would be operated at a temperature between 1050 and $1200^{\circ} \mathrm{C}$. Molten glass produced in the melter would be poured into stainless-steel canisters, sealed, and transported to an interim storage facility awaiting final disposal. The melter off-gas consisting of hazardous ( $\mathrm{Hg}$ and $\mathrm{Cd}$ ) and radioactive ( $\mathrm{Cs}, \mathrm{Tc}$, and $\mathrm{Ru}$ ) materials would be treated in an off-gas treatment facility prior to venting in a stack.

\section{Assumptions Used in Completing Mass Balance Calculations}

- The vitrification process destroys all nitrates and hydroxides. The ${ }^{129} \mathrm{I}$ and ${ }^{3} \mathrm{H}$ in the feed are volatilized during vitrification of the waste.

- The glass density is $2.6 \mathrm{~g} / \mathrm{cm}^{3}$ with a waste loading of $33 \mathrm{wt} \%$ solids. (D. A. Knecht, J. R. Berreth, "FY-88 Update: Strategy Planning Document for the Long-term Management of ICPP High-level Radioactive Waste," WIN-225, September 1988; D. C. Stewart, Data for Radioactive Waste Management and Nuclear Applications, John Wiley and Sons, Table 5.18.)

- The glass-ceramic density is $3.2 \mathrm{~g} / \mathrm{cm}^{3}$ with a waste loading of $70 \mathrm{wt} \%$ solids.

- The undissolved solids (UDS) are assumed to be removed prior to separation processing via filtration or centrifugation for the transuranic (TRUEX) or freeze crystallization (FC) processing options. The UDS are added to the HAW fraction with no further waste processing ramifications; solid criticality concerns will have to be addressed.

\section{MAJOR DEVELOPMENT ISSUES}

Much of the development work completed within the DOE complex and internationally has been completed with HLW slurries, whereas the proposed ICPP vitrification process must be capable of vitrifying calcine. Hence, much of the development work required on the ICPP vitrification process would be to develop solids handling techniques, solids blending, solids sampling, and chemical analysis techniques.

Pneumatic retrieval and transport of the calcine has been proposed as a method to remove the calcine from the bin sets and deliver it to the various unit operations. Calcine transport has been demonstrated at the ICPP for a number of years and would not present any obvious difficulties. However, a significant amount of development is required to accomplish calcine retrieval from the existing bin sets. 
Solids blending in general would require additional development. As the frit composition and waste loading are a function of calcine composition; a calcine/calcine blender, a sampling scheme, and suitable chemical analysis techniques would need to be developed to allow for reproducible sampling and accurate analysis of calcine. Additionally, a suitable calcine/calcine blender would need to be developed. The blender size would be a function of the turn around time required for calcine analysis and the ability to change the frit composition based on the composition of the calcine.

Several development issues are associated with the glass melter. The possible glass melter technologies include the following: 1) a joule-heated ceramic melter, 2) a stirred melter, and 3) an inductively-heated melter as presently used by COGEMA. Joule-heated ceramic melters have been studied for use at Savannah River, Hanford, and West Valley. A limited amount of development work on a joule-heated ceramic melter has been accomplished with simulated ICPP calcine. The melter was operated for 40 hours at which time the test was terminated and several modifications to the melter system were recommended. The principal issue identified during initial testing was the corrosivity of the glass. Development of better fabrication techniques and melter materials was recommended. Additionally, recent testing at Savannah River has shown accumulation of heavy metals in the melter bottom after extended operating times.

A stirred melter has recently been recommended as a possible alternative to the joule-heated ceramic melter. The main issue associated with this melter technology is selection of the materials of construction. The stirrer and the melter crucible are used as the electrodes and must be conductive. Conductive materials under consideration include Inconel 690, carbon, and Haynes alloy 230. Additional development issues would be the effect of the stirring action on waste loading and frit selection.

The inductively-heated COGEMA melter would be useable at the ICPP only if a separations process is implemented. The throughput of this melter type is low compared to the other two melter alternatives as inductive heating is not capable of transferring large amounts of energy to the glass quickly. Development issues associated with the COGEMA melter would include demonstration of the technology on ICPP wastes, the effect of this melter type on waste loading and frit composition.

It is anticipated that the off-gas from the glass melter would be different from the off-gas produced at other facilities and on-site at the New Waste Calcining Facility (NWCF). As a result, modifications to existing off-gas treatment schemes would be required before implementation at the ICPP.

\section{GLASS-CERAMIC}

The production of an acceptable glass-ceramic waste form would begin with the receipt of calcine into a Waste Immobilization Facility (WIF). Newly generated calcine from the NWCF would be pneumatically transported directly to the WIF. 


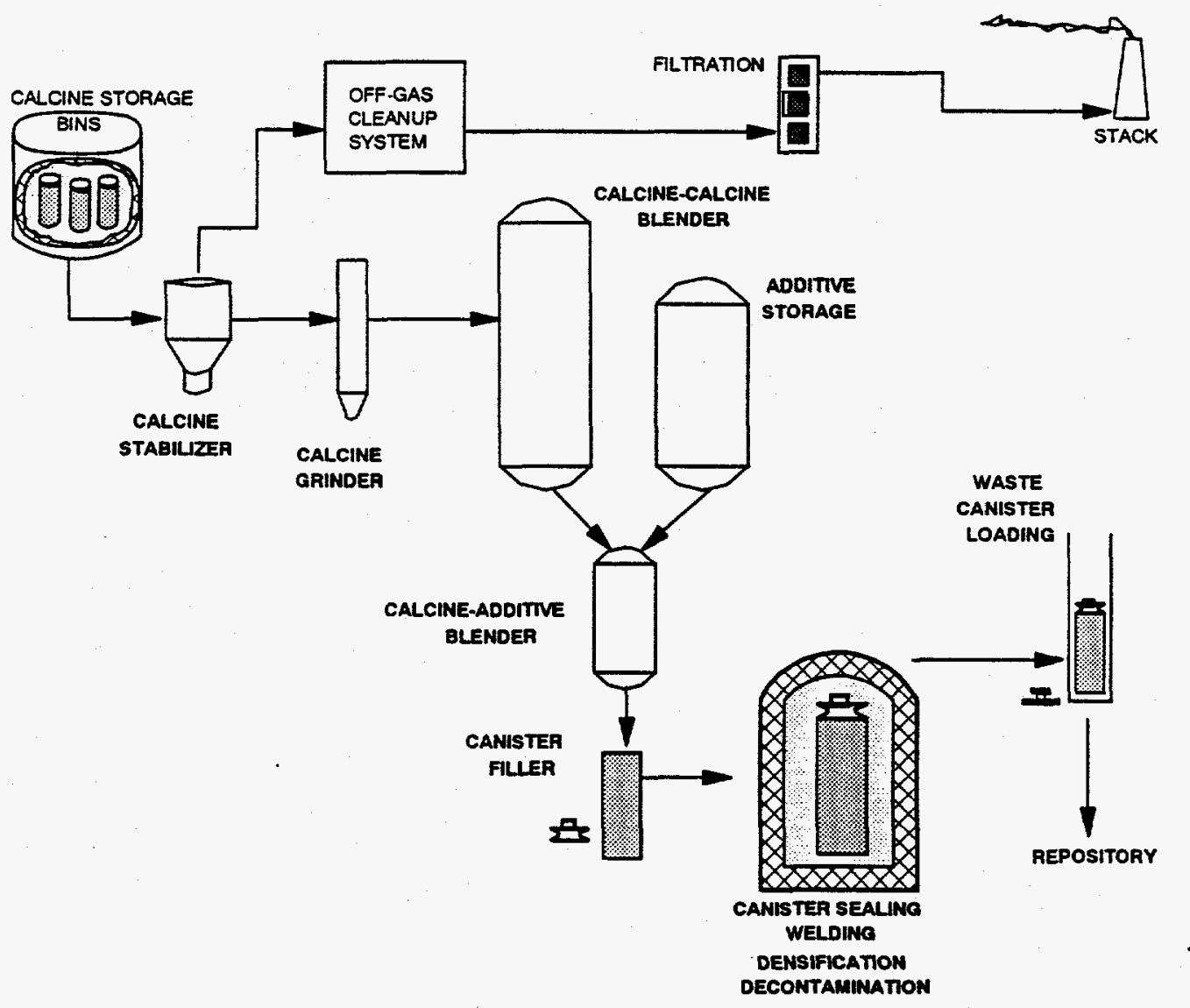

Figure 16. Glass-Ceramic Process

Previously generated calcine stored on-site would be retrieved and transported to the WIF. Generation of a glass-ceramic waste form, as depicted in Figure 16, begins with volatiles removal from the calcine. The calcine feed would be stabilized at $600^{\circ} \mathrm{C}$ to remove nitrates and water adsorbed to the calcine. A particle sizing step would be performed to reduce the particle size distribution span. This would decrease segregation tendencies induced by solid handling steps throughout the process. It also appears to improve waste form reaction kinetics during the densification step, which results in an increase in product durability and a decrease in the processing time.

The varying composition of the calcines produced in the NWCF and the layered nature of calcine in the storage bins, would make it necessary to blend a 24-hour supply of calcine. The calcine composition would be analyzed after blending and the analysis used to determine the additive composition. The frit and reactants would be sized similar to that of the calcine, and thoroughly mixed with the calcine.

The calcine-additive mixture would be loaded into a processing can for the densification process. The equipment used to fill the canister must be designed to eliminate or minimize dust and contaminant escape, and to fill the canister as completely as possible. Pre-compaction before densification would be necessary to obtain maximum can-fill densities, limit can deformation 
during the high temperature/pressure product formation step, and produce a product of near theoretical density.

The filled canister would be evacuated, sealed, and the surface cleaned prior to densification. Evacuation is required because any gas (such as air or residual gases from calcination) left in the canister would expand under heat, resulting in a porous product and the possibility of a breached canister.

Fully dense, or near fully dense, glass-ceramic waste forms are attainable under high temperature and pressure. A Hot Isostatic Press (HIP) is currently used to form the glass-ceramic in experimental work. Two densified process canisters would be stacked together in a repository waste canister and the canister sealed.

The off-gas from all unit operations would consist of solids separation using cyclones, sintered metal filters, and HEPA filters. Off-gas cleanup systems would be required in the stabilization operation. The stabilizer off-gas system would be similar to the calciner off-gas system (see calcination section). The HIP operation is carried out in an Argon atmosphere. The gas would be monitored to ensure that no release had occurred in the HIP process, and the gas sent through a clean up system similar to the glass melters (see glass section). The Argon would then be released or recycled.

\section{Assumptions Used in Completing Mass Balance Calculations}

- The process destroys all nitrates and hydroxides. The ${ }^{129} \mathrm{I}$ and ${ }^{3} \mathrm{H}$ in the feed are volatilized during processing of the waste.

- The glass-ceramic density is $3.2 \mathrm{~g} / \mathrm{cm}^{3}$ with a waste loading of $70 \mathrm{wt} \%$ solids.

- The UDS are assumed to be removed prior to separation processing via filtration or centrifugation for the TRUEX or FC processing options. The UDS are added to the HAW fraction with no further waste processing ramifications; solid criticality concerns will have to be addressed.

\section{MAJOR DEVELOPMENT ISSUES}

Currently, the solids characteristics and flow properties of the various types of calcine (both radioactive and simulated nonradioactive) are not known, but would need to be determined for the scale up of bulk solids handling and blending systems.

A criteria for estimating the degree of homogeneity of the calcine blend and the calcine-additive blend must be determined. Also sampling of the calcine blend and the calcine-additive blend must be established. This is a critical step in the glass-ceramic process. If the calcine is not homogeneous when sampled (and sampled properly), an unsuitable frit/additive may be added. 
The calcine-additive blend must be homogeneous to obtain a homogeneous glass-ceramic waste form.

The HIP must be modified for remote operations. This is a high maintenance item which will require a large development effort. An undetermined product quality verification test needs to be developed to ensure that drilling or cutting the large canisters will not be needed to approve the product. 


\subsection{Direct Disposal Options}

This section will discuss and describe options for waste disposal which do not attempt to separate radioactive components from inert components in the spent nuclear fuel, sodium-bearing radioactive liquid waste, and calcine. Section 4.1 discusses the use of high integrity canisters for containment and disposal of wastes. High integrity canisters are containers which are engineered and constructed to withstand the forces of nature in a federal repository for at least 10,000 years. Section 4.2 describes waste disposal alternatives that include operations that pretreat or precondition the wastes before they are packaged into canisters which would be transported to a federal repository. Pretreatment consists of operations such as size reduction of the waste, encapsulation in a binding material after size reduction, or calcination, but is not limited to these methods. Section 4.3 describes conversion of radioactive sodium-bearing liquid waste and calcine to a transportable, cementitious waste form and disposal in a repository system called Greater Confinement Disposal. This concept consists of direct placement of the radioactive wastes in one of the Nevada Test Site's weapon test locations.

Figure 2 on page 4 of this report depicts overall dispositioning options for ICPP radioactive wastes.

\subsection{Use of High-Integrity Canisters}

At a DOE-HQ meeting in October 1992, Idaho was asked to serve as the lead team in developing guidelines for a repository waste form barrier/canister, and also to determine how a 10,000-year canister should be considered in conjunction with the decision process for DOE spent fuel/HLW technology development. Through team meetings in FY 1993, the status of DOE HLW and SNF, such as stored at the INEL, and long-lived barrier/canister technology development were reviewed. The developmental needs required to reach a decision on the cost and feasibility of this option, as applied to DOE HLW/SNF, will be established, and will lead to an initial plan for evaluation of the canister option compared to other disposal options. Other activities under way by DOE-RW are primarily related to the long-lived waste package components such as the Multiple Purpose Canister (MPC) study and Engineered Barrier System (EBS). Development will be leveraged through ongoing technical reviews and future team meetings.

The designs for a long-lived canister/barrier presented at a $1991 \mathrm{DOE}-\mathrm{RW}$ workshop still appear to be relevant, but very little verification testing has taken place or is planned for the near future. An update of this workshop was held on September 21-23, 1993, and new waste package information was assimilated into current practice. An advanced conceptual design of a waste package is in development with an expected completion date in June 1996, by Babcock \& Wilcox, one of the Management \& Operating contractors to RW. Seven waste package designs are being evaluated, including some which are being evaluated for long-term performance (10,000-year life). A MPC Implementation Program, in conjunction with commercial fuel 
transportation, storage, and disposal issues, was started in February 1993, by TRW. It is assumed that the MPC study will examine criticality as one of the parameters.

\section{PROCESS DESCRIPTION}

The direct disposal process that utilizes high-integrity canisters is shown in Figure 17. The calcine and SNF are retrieved from storage and packaged to high-integrity canisters, and shipped for disposal to a geologic repository. For the basis of this study, a nominally 2 -foot diameter by 10 -foot high canister will be used to compare the various options. If a larger diameter MPC is used, the smaller canisters containing the HLW and spent fuel will be positioned inside the larger canister.

Specific storage methods include the following two options, which assume all sodium-bearing waste will be converted to calcine:

1. Calcine in canisters: spent nuclear fuel (SNF) limited to $0.7 \mathrm{~kg} \mathrm{U-235}$ per canister, with no intermixing of calcine with SNF.

2. Calcine in canisters: SNF limited to $10 \mathrm{~kg} \mathrm{U-235}$ per canister, with no intermixing of calcine with SNF.

The quantities of calcine and SNF and number of resulting canisters are shown in Table 23 as Option 1. These quantities were calculated by Systems Analysis personnel for the performance assessment being developed under contract by Sandia National Laboratory.

The major assumptions include the following conditions:

- That SNF can be cut and packaged into canisters containing 0.7 or $10 \mathrm{~kg} \mathrm{U-235.}$ The mass limits can be verified.

- That designated U-235 mass limits can be demonstrated to meet repository acceptance requirements.

- That calcine can be readily retrieved and packaged for shipment

- That existing waste acceptance requirements can be sufficiently modified to allow calcine, glass, glass ceramic, and SNF to be disposed at the specified mass limits and waste form compositions.

- That canisters with acceptable properties, including limited corrosion under expected repository conditions, can be designed, fabricated and tested. 


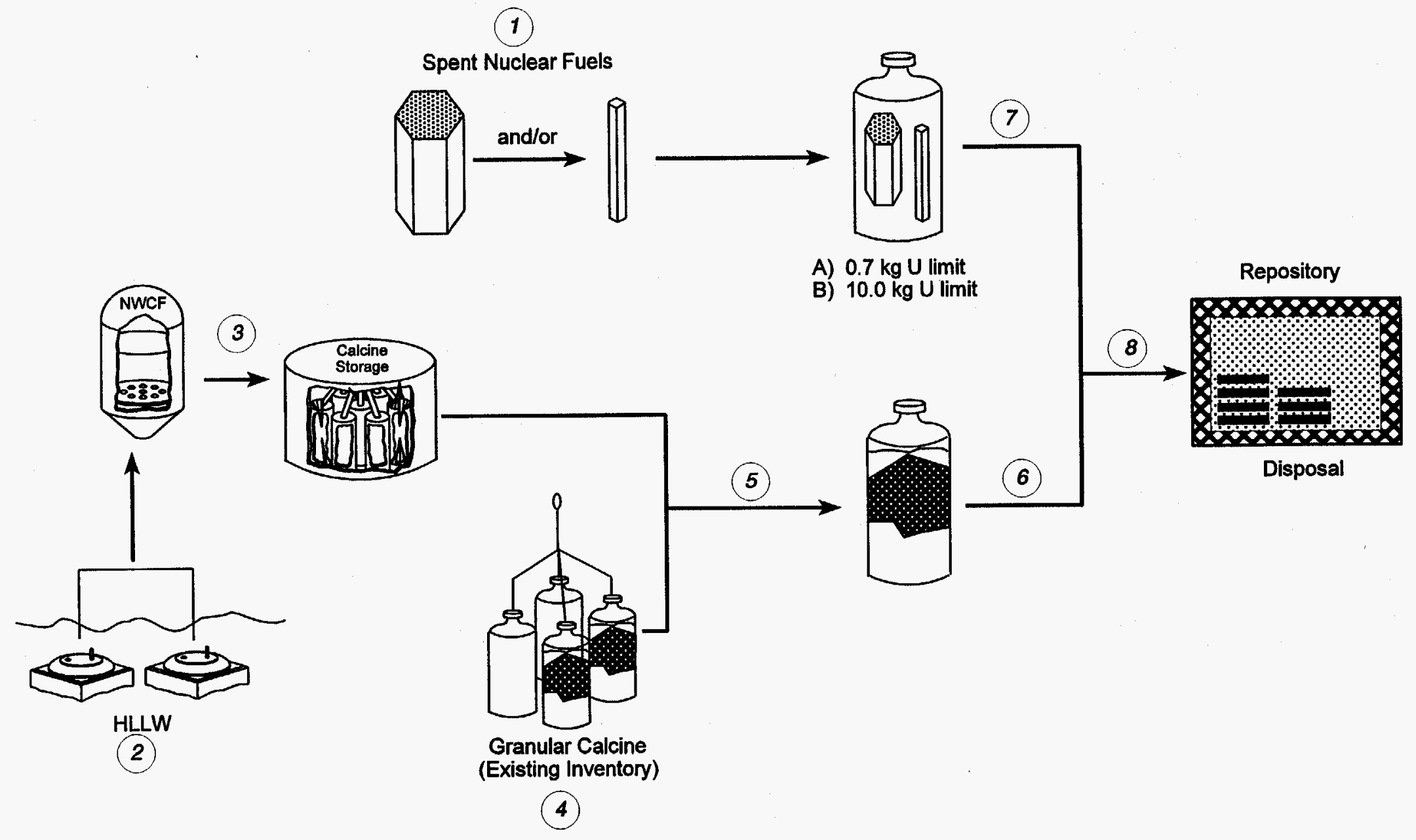

Figure 17. Direct Disposal Using High Integrity Canisters 
- That glass and glass-ceramic technologies are acceptable and processing facilities will be available.

The waste form for this option includes SNF and calcine (graphite, Zircaloy, other metal fuel forms). Waste acceptance specifications will have to be developed, and existing regulations in 10 CFR 60 will likely require modification to allow a non-monolithic material to be used.

The primary advantage of this high integrity canister option is in the simplicity of not requiring the processing of the SNF and calcine. A specific advantage inherent at the INEL is that this process will require very little change in the existing processing technology. Disadvantages include establishing acceptable requirements by the regulators, as well as determining the potential development and testing time of the canister to confirm anticipated repository behavior. Further treatment of the waste may be required to meet waste acceptance specifications.

\section{TECHNOLOGY STATUS}

SNF canning is a well-established technology. Calcine retrieval from ICPP bins and packaging in the high-integrity canisters needs to be developed in both pilot plant and full-scale demonstration tests. Preliminary corrosion tests were conducted for a very limited set of canister materials under only a few repository scenarios. Long-term disposal conditions at Yucca Mountain, or at other candidate repositories, need to be established through underground testing. Additionally, extensive materials development work is required to produce high-integrity canisters.

An estimated development schedule is outlined in the following:

- Nonradioactive calcine retrieval pilot plant tests -6 years

- Calcine retrieval full-scale mock-up/demonstration tests -10 years

- Calcine packaging verification nonradioactive mock-up - 4 years

- Material tests to select candidate canister materials - 3 years

- Materials testing under experience repository conditions to simulate repository 10,000-yr behavior for each postulated corrosion mechanism, running concurrently - 7 years

\subsection{Pre-Conditioning Processing Options}

All of the options presented within this section are based on the following statements which are needed to complete material balance calculations. All ICPP liquid wastes will be calcined. Low feed blend ratios will be used, within a conservative range, where pilot-scale calcination processing experience has recommended concentration limits for various calcine feed types. The low blend ratios for $\mathrm{Na}$ and decon liquid wastes were assumed to be 5.3 and $0.4 \mathrm{~mol} \%$ respectively, with dilution by blending cold materials, for this evaluation. 
The SNF in this study includes; 1) Peach Bottom and Fort St. Vrain (FSV) graphite fuels, both in ICPP inventories and at FSV, 2) Special fuels, including commercial fuels which are inventoried at the INEL, and 3) Zircaloy fuels inventoried at the INEL. With exception of the FSV graphite fuels, most of the fuel values are for INEL inventories. In general, efforts were made to be consistent with fuel inventories estimated in a Performance Assessment prepared under contract to the Sandia National Laboratory, report number SAND94-2563/2.

Fuel shredding is thought to be feasible from both criticality and processability standpoints. In addition, a $40 \%$ void volume due to coolant filled regions is estimated for the entire fuel inventory. Assuming the fuel can be shredded to a size less than the smallest cooling channel, which is approximately $5 / 8$ inch for FSV, the $40 \%$ volume reduction is utilized in volume calculations.

Encapsulation of shredded fuel is theoretically achievable by the addition of glass for this analysis. Adequate encapsulation of shredded fuel is assumed to be achievable for a $70 \mathrm{wt} \%$ fuel loaded waste package.

A standard canister size, $61 \mathrm{~cm}$ diameter $\times 300 \mathrm{~cm}$ tall, has been adopted for packaging all fuels and wastes. These canisters have a $0.626 \mathrm{~m}^{3}$ capacity at $85 \%$ of full and weigh $500 \mathrm{~kg}$ each. A smaller canister (approximately $18^{\prime \prime} \times 18^{\prime \prime}$ ) has been proposed, and will have a significant impact on volumes sent to a repository for the $0.7 \mathrm{Kg} \mathrm{U}-235$ cases.

The volumes shown in the material balances indicate packaged waste and fuel volumes only. Allowances for overpack canisters or the void space in the waste and fuel package are not included in the reported volume sent to a repository. However, the estimated waste/fuel package mass destined for a repository includes the canister weight which is approximately $500 \mathrm{~kg} / \mathrm{per}$ canister. Major assumptions are similar to those made for the direct canning option described in Section 4.1 .

The primary advantage of this option is the volume reduction achieved through size reduction of the SNF and packaging of SNF and vitrified material in the same canister. A secondary advantage is that existing vitrification technology and glass-ceramic technology developed at ICPP can be utilized.

A major disadvantage is the time required to develop size reduction technology for an inherently mechanical intensive process. Criticality concerns may be a major obstacle to success when reducing the size of fuels enriched with uranium-235. Waste acceptance specifications, unlike those presently developed, will have to be developed for glass encapsulation of shredded fuels. New facilities will be required and essentially none of the existing separations technology can be utilized in executing these options. 
The direct disposal option for shredding SNF and pouring glass into the void canister space is shown in Figure 18. The schematic illustrates the estimated scenario for both the 0.7 and $10 \mathrm{~kg}$ U-235 limit. The objective of this option is to package shredded fuel with glass from vitrified calcines. The glass packaged per canister was limited to the void spaces after packaging the fuel, given the two U-235 limitations. The material balance for this option is detailed in Tables 15 and 16 for the $0.7 \mathrm{~kg}$ and $10 \mathrm{~kg} \mathrm{U}-235$ limits respectively. It is estimated that adequate amounts of glass will be packaged per canister to encapsulate the shredded fuel for the $0.7 \mathrm{~kg} \mathrm{U}-235$ case only. The $10 \mathrm{~kg} \mathrm{U}-235$ case has inadequate void space for packaging sufficient quantities of glass to realize any benefit of fuel encapsulation.

The fuel will likely require a series of mechanical shredders to achieve the maximum volume reduction. For the $0.7 \mathrm{~kg} \mathrm{U}-235$ limit case, the shredded fuel is packaged with glass from a calcine vitrification plant. The material balance shows that the volume of glass made from ICPP calcines is not sufficient to fill the void spaces for the total number of canisters required to package fuel at the $0.7 \mathrm{~kg} \mathrm{U}-235$ limit. Calculations indicate that an additional $65,850 \mathrm{~m}^{3}$ of non-radioactive glass will be needed to encapsulate the remaining fuel. This option produces $79,234 \mathrm{~m}^{3}$ of packaged fuel and wastes from $401 \mathrm{~m}^{3}$ of fuel and $8,065 \mathrm{~m}^{3}$ of calcine.

Material balance calculations for the $10 \mathrm{~kg} \mathrm{U}-235$ limit case indicate that there would be an excess of glass made from ICPP calcines. Many of the canisters would not have space available for glass after packaging fuels at the $10 \mathrm{~kg} \mathrm{U}-235$ limit. As a result, 8,964 canisters will not contain enough glass to adequately encapsulate the shredded fuels. An additional 12,420 canisters are required to package the left over glass from vitrification of ICPP calcines. However, due to the higher U-235 packaging limit this option produces $13,386 \mathrm{~m}^{3}$ of packaged fuel and wastes from $401 \mathrm{~m}^{3}$ of fuel and $8,065 \mathrm{~m}^{3}$ of calcine. 


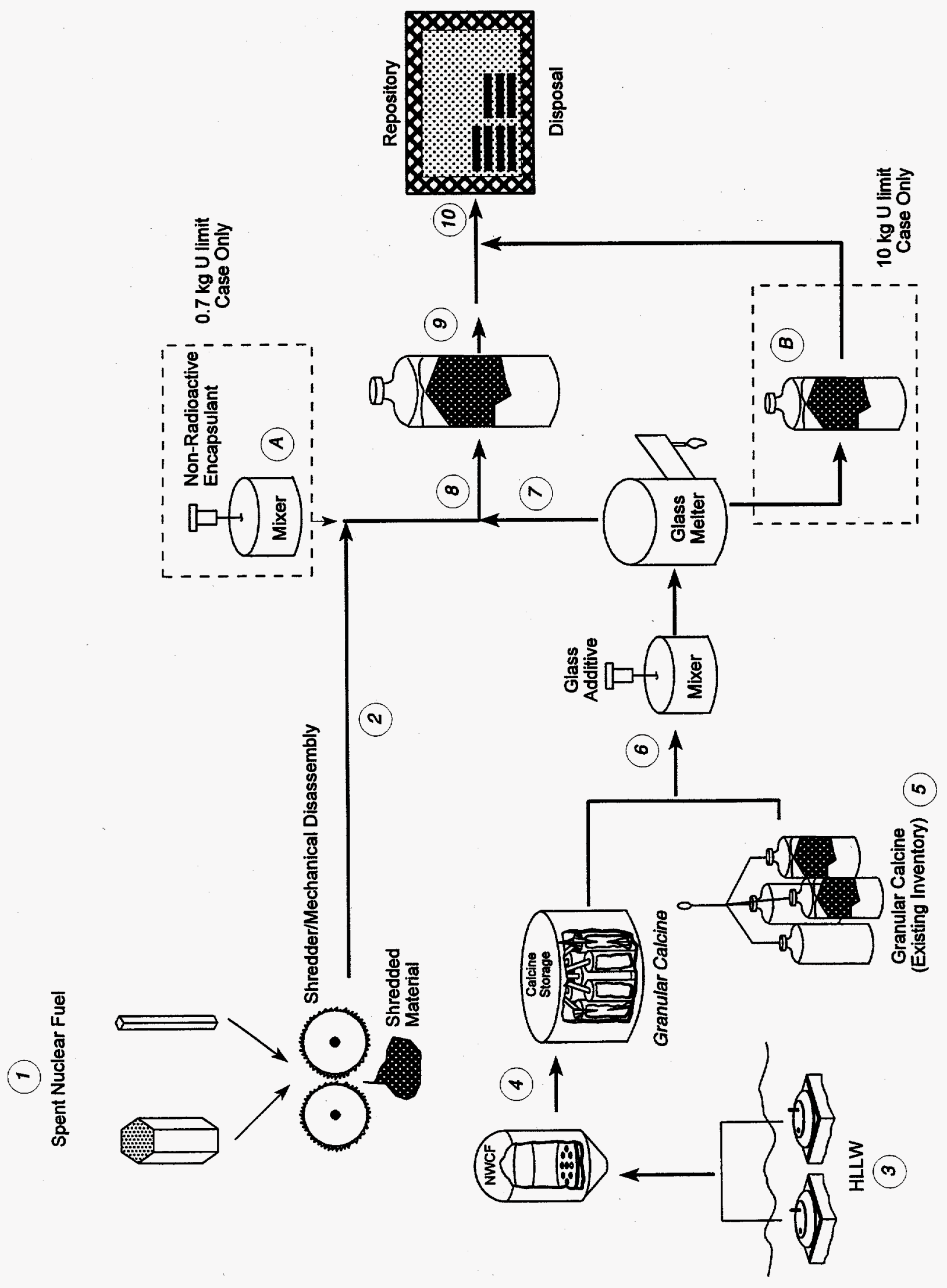

 


\section{Encapsulation of Shredded Fuel and Glass Vitrification of Calcine Process Description}

The direct disposal option for encapsulating shredded SNF with cold glass and glass vitrification of ICPP calcines is shown in Figure 19. The ICPP calcine would be vitrified and packaged separately from the fuels. The schematic illustrates the estimated scenario for both the 0.7 and $10 \mathrm{~kg} \mathrm{U}-235$ limit. The material balance for this option is detailed in Tables 17 and 18 for the $0.7 \mathrm{~kg}$ and $10 \mathrm{~kg} \mathrm{U}-235$ limits respectively.

As described above, adequate void space will be available to encapsulate the shredded fuel with glass for the $0.7 \mathrm{~kg} \mathrm{U}-235$ case only. The $10 \mathrm{~kg} \mathrm{U}-235$ case has inadequate void space for packaging of glass to realize any benefit of fuel encapsulation.

Therefore, the fuel loading per canister was limited to $70 \mathrm{wt} \%$ to allow for encapsulation of shredded fuel by the addition of glass. This action will effectively reduce the mass of U-235 per canister below the specified $10 \mathrm{~kg}$. However, if $70 \mathrm{wt} \%$ fuel loading is a valid assumption for fuel encapsulation, all fuels will be packaged in more stable, leach resistant form.

Calculations indicate that $78,994 \mathrm{~m}^{3}$ of cold, non-radioactive glass will be needed to encapsulate the shredded fuel for the $0.7 \mathrm{~kg} \mathrm{U}-235$ option. Vitrification of ICPP calcines will produce 13,136 $\mathrm{m}^{3}$ of glass. This option produced $109,199 \mathrm{~m}^{3}$ of packaged fuel and wastes from $401 \mathrm{~m}^{3}$ of fuel and $8,065 \mathrm{~m}^{3}$ of calcine. The $10 \mathrm{~kg} \mathrm{U}-235$ option requires only $171 \mathrm{~m}^{3}$ of encapsulant and produces $13,557 \mathrm{~m}^{3}$ of encapsulated fuel and vitrified calcine from the same beginning waste and fuel inventory. 


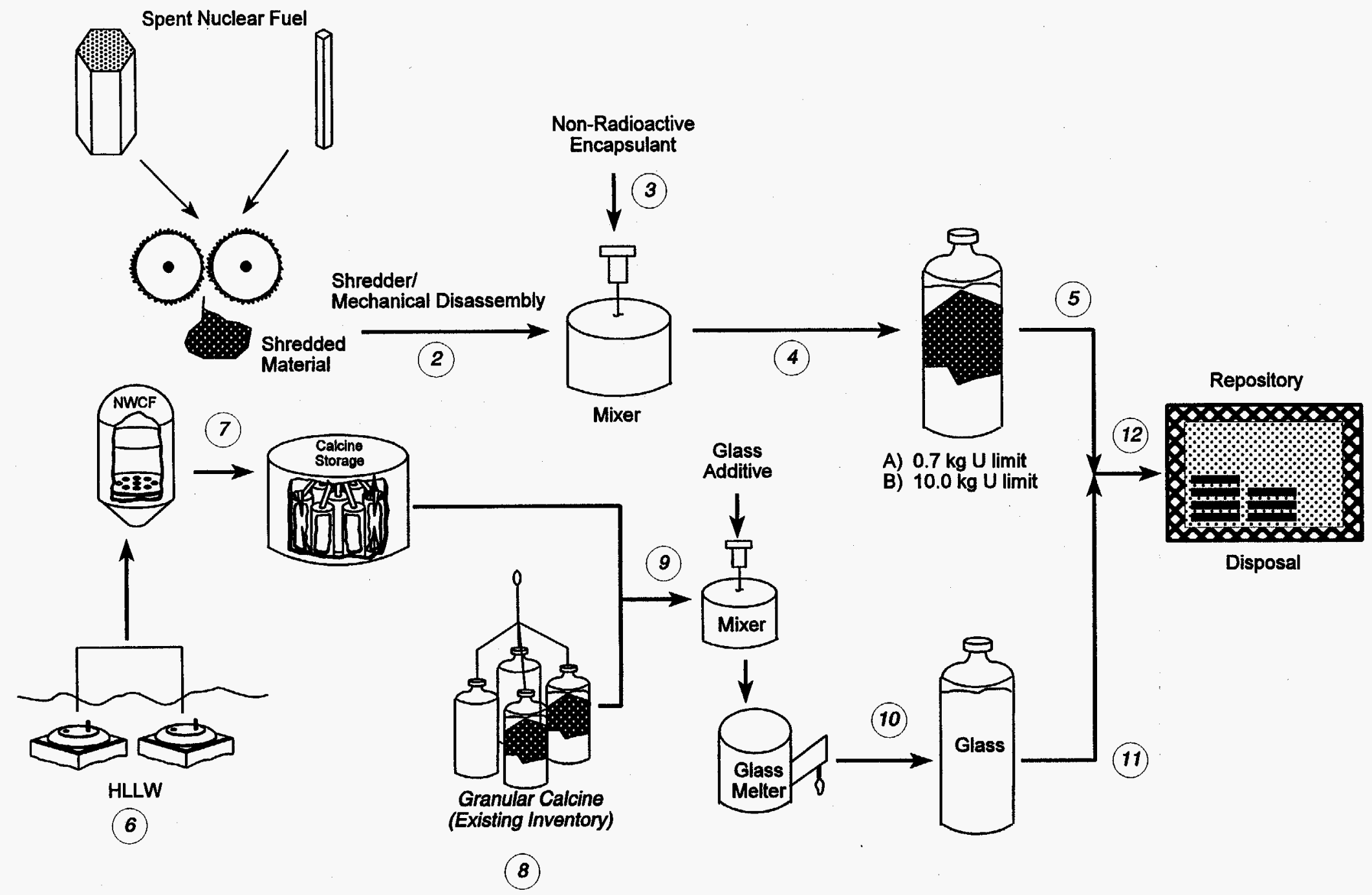

Figure 19. Encapsulation of Shredded Fuel and Glass Vitrification of Calcine 
Process Description of Encapsulation of Shredded Fuel and Glass Ceramic Immobilization

The direct disposal option for encapsulating shredded SNF with cold glass and glass-ceramic immobilization of ICPP calcines is shown in Figure 20. The calcine will be immobilized by glass-ceramic technology currently being developed at ICPP and packaged separately from the fuels. The schematic illustrates the estimated scenario for both the 0.7 and $10 \mathrm{~kg} \mathrm{U}-235$ limit. The material balance for this option is detailed in Tables 19 and 20 for the $0.7 \mathrm{~kg}$ and $10 \mathrm{~kg} \mathrm{U}$ 235 limits respectively.

The assumptions and calculations for encapsulating shredded fuels for this option are identical to that shown in the previous option. However, using glass-ceramic technology to immobilize ICPP calcines produces only $5,000 \mathrm{~m}^{3}$ of packaged waste. This option produces $84,234 \mathrm{~m}^{3}$ of packaged fuel and wastes from $401 \mathrm{~m}^{3}$ of fuel and $8,065 \mathrm{~m}^{3}$ of calcine for the $0.7 \mathrm{~kg} \mathrm{U}-235$ option. The $10 \mathrm{~kg} \mathrm{U}-235$ option produces $5,411 \mathrm{~m}^{3}$ of fuel and glass-ceramic from the same beginning waste and fuel inventory. Although this option represents the process which produces the smallest volume of waste for a repository, an extra facility is necessary to accommodate the glass-ceramic process. 
(1)

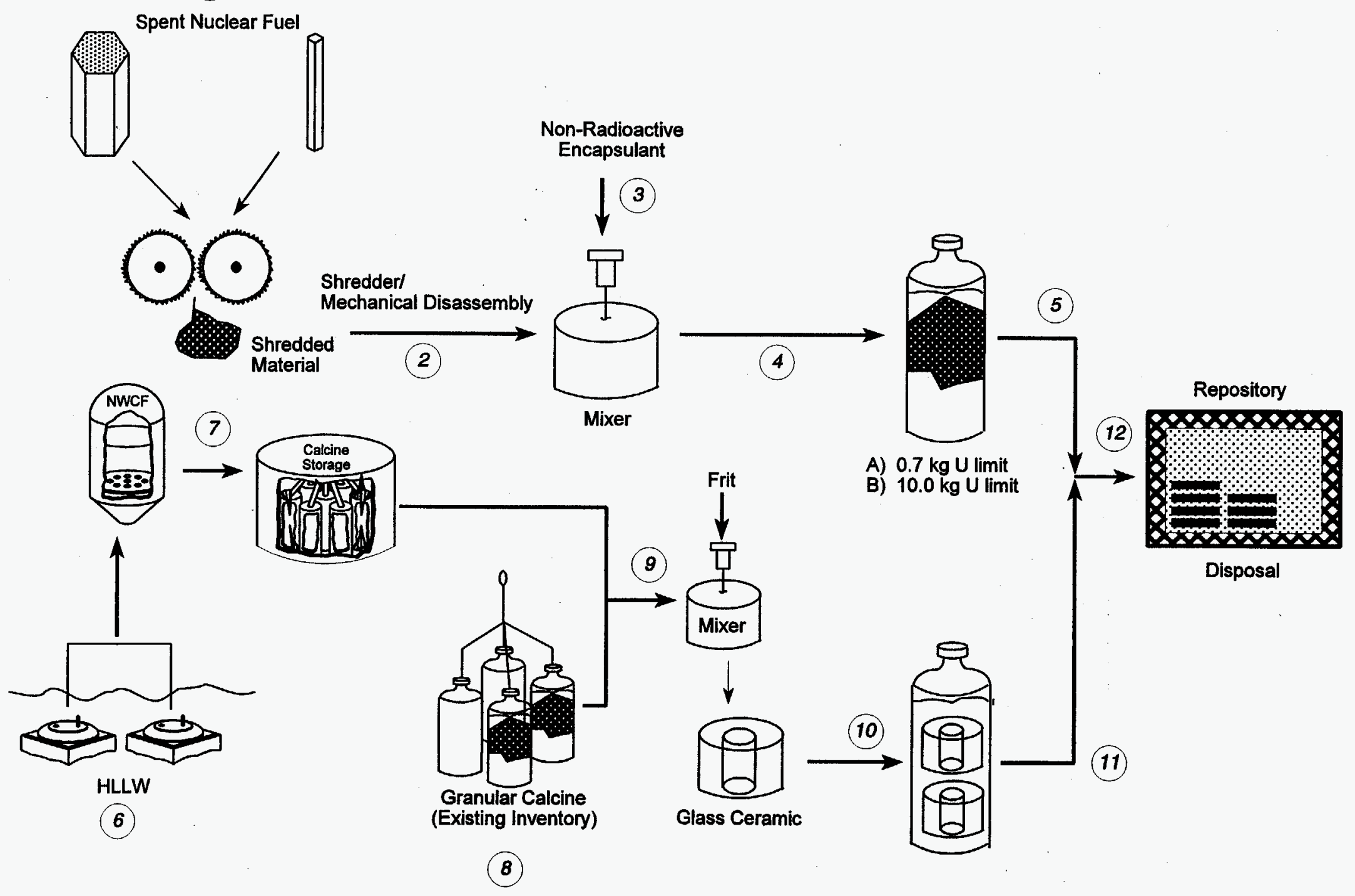

Figure 20. Process Description of Encapsulation of Shredded Fuel and Glass Ceramic Immobilization 
Table 15. Encapsulation of Shredded Fuel with Glass and Calcine Vitrification, $0.7 \mathrm{~kg}$ U-235 Limit

\begin{tabular}{|c|c|c|c|c|c|c|c|c|c|c|c|}
\hline COMPONENT & STREEAMT 1 & STRREAML2 & STREAMIA & STRREAM 3 & TSIREAM 4 & STREAM 5 & TSTREAMTE & TStREAMT & TSIREEAM 8 & ISTREEAMIS & TSTREAMN TO \\
\hline mass, $\mathrm{kg}$ & 1028904 & 1028904 & & & & & & & 1028904 & 1028904 & 1028904 \\
\hline VOLUME, $\mathrm{m} 3$ & 401 & 241 & & & & & & & 241 & 241 & 241 \\
\hline mass, $\mathrm{kg}$ & & & & & & & & & & & \\
\hline VOLUME, $m 3$ & & & & 7421 & & & & & & & \\
\hline CALCINE & & & & & 5340912 & 5950000 & 11290912 & & & & \\
\hline VOLUME, $\mathrm{m} 3$ & & & & & 3815 & 4250 & 8065 & & & & \\
\hline GLASS-CERAMIC. mass, kg & & & & & & & & & & & \\
\hline VOLUME, $\mathrm{m} 3$ & & & & & & & & & & & \\
\hline mass, $\mathrm{kg}$ & & & & & & & & 34179204 & 34179204 & 34179204 & 34179204 \\
\hline VOLUME, $m 3$ & & & & & & & & 13146 & 13146 & 13146 & 13146 \\
\hline ENCAPSULANT, mass, kg & & & 171204130 & & & & & & 171204130 & 171204130 & 171204130 \\
\hline VOLUME, $\mathrm{m} 3$ & & & 65848 & & & & & & 65848 & 65848 & 65848 \\
\hline CANISTERS & & & & & & & & & & incl. in glass & incl, in glass \\
\hline CALCINE & & & & & & & & & & & \\
\hline G-C & & & & & & & & & & & \\
\hline GLASS & & & & & & & & & & 126572 & 126572 \\
\hline TOTAL CANISTERS & & & & & & & & & & 126572 & 126572 \\
\hline TOTAL CANISTER WT, kg & & & & & & & & & & 63286071 & 63286071 \\
\hline \multicolumn{12}{|c|}{ TOTAL TO REPOSITORY } \\
\hline MASS, $m t$ & & & & & & & & & & 269698 & 269698 \\
\hline VOLUME, m3 & & & & & & & & & & 79234 & 79234 \\
\hline
\end{tabular}


Table 16. Encapsulation of Shredded Fuel with Glass and Calcine Vitrification, 10 kd U-235 Limit

\begin{tabular}{|c|c|c|c|c|c|c|c|c|c|c|c|}
\hline COMPONENT & STREAM 1 & STREAM 2 & STREAM 3 & STREAM 4 & STREAM 5 & STREAM 6 & STREAM 7 & STREAMB & STREAM 8 & STIREAM 9 & STREAM 10 \\
\hline mass, $\mathrm{kg}$ & 1028904 & 1028904 & & & & & & & 1028904 & 1028904 & 1028904 \\
\hline VOLUME, $m 3$ & 401 & 241 & & & & & & & 241 & 241 & 241 \\
\hline mass, $\mathrm{kg}$ & & & & & & & & & & & \\
\hline VOL.UME, m3 & & & 7421 & & & & & & & & \\
\hline CALCINE & & & & 5340912 & 5950000 & 11290912 & & & & & \\
\hline VOLUME, m3 & & & & 3815 & 4250 & 8065 & & & & & \\
\hline \multicolumn{12}{|l|}{ GLASS-CERAMIC mass, $\mathrm{kg}$} \\
\hline VOLUME, $\mathrm{m} 3$ & & & & & & & & & & & \\
\hline mass, $\mathrm{kg}$ & & & & & & & 7519302 & 10884885 & 7519302 & 7519302 & 18404187 \\
\hline VOLUME, $\mathrm{m} 3$ & & & & & & & 5371 & 7775 & 5371 & 5371 & 13146 \\
\hline \multicolumn{12}{|l|}{ ENCAPSULANT, mass, $\mathrm{kg}$} \\
\hline VOLUME, m3 & & & & & & & & & & & \\
\hline CANISTERS SNF & & & & & & & & & & incl. in glass & incl. in glass \\
\hline \multicolumn{12}{|l|}{ CALCINE } \\
\hline \multicolumn{12}{|l|}{$G-C$} \\
\hline GLASS & & & & & & & & 12420 & & 8964 & 21384 \\
\hline TOTAL CANISTERS & & & & & & & & 12420 & & 8964 & 21384 \\
\hline TOTAL CANISTER WT, $\mathrm{kg}$ & & & & & & & & 6209998 & & 4482030 & 10692028 \\
\hline \multicolumn{12}{|c|}{ TOTAL TO REPOSITORY } \\
\hline MASS, $\mathrm{mt}$ & & & & & & & & 17095 & & 13030 & 30125 \\
\hline VOLUME, m3 & & & & & & & & 7775 & & 5612 & 13386 \\
\hline
\end{tabular}


Table 17. Encapsulation of Shredded Fuel with Glass and Calcine Vitrification, $0.7 \mathrm{~kg}$ U-235 Limit

\begin{tabular}{|c|c|c|c|c|c|c|c|c|c|c|c|c|}
\hline COMPONENT & STREAM 1 & STREAM 2 & STREAM 3 & STREAM 4 & STREAM 5 & STREAM 6 & STREAL 7 & STREAM 8 & STREAM 9 & STREAM 10 & STREAM 11 & STREAM 12 \\
\hline mass, $\mathrm{kg}$ & 1028904 & 1028904 & & 1028904 & 1028904 & & & & & & & 1028904 \\
\hline VOLUME, $\mathrm{m} 3$ & 401 & 241 & & 241 & 241 & & & & & & & 241 \\
\hline mass, $\mathrm{kg}$ & & & & & & & & & & & & \\
\hline VOLUME, m3 & & & & & & 7421 & & & & & & \\
\hline CALCINE & & & & & & & 5340912 & 5950000 & 11290912 & & & \\
\hline VOLUME, $\mathrm{m} 3$ & & & & & & & 3815 & 4250 & 8065 & & & \\
\hline GLASS-CERAMIC mass, kg & & & & & & & & & & & & \\
\hline VOLUME, $m 3$ & & & & & & & & & & & & \\
\hline mass, $\mathrm{kg}$ & & & & & & & & & & 34179204 & 34179204 & 34179204 \\
\hline VOLUME, $\mathrm{m} 3$ & & & & & & & & & & 13146 & 13146 & 13146 \\
\hline ENCAPSULANT, mass, $\mathrm{kg}$ & & & 205383 & 205383 & 205383 & & & & & & & 205383 \\
\hline VOLUME, $\mathrm{m3}$ & & & 78994 & 78994 & 78994 & & & & & & & 78994 \\
\hline CANISTERS SNF & & & & & 126572 & & & & & & & 126572 \\
\hline CALCINE & & & & & & & & & & & & \\
\hline G-C & & & & & & & & & & & & \\
\hline GLASS & & & & & & & & & & & 21000 & 21000 \\
\hline TOTAL & & & & & 126572 & & & & & & 21000 & 147572 \\
\hline TOTAL CANISTER WT, $\mathrm{kg}$ & & & & & 63286071 & & & & & & 10499878 & 73785950 \\
\hline \multicolumn{13}{|c|}{ TOTAL TO REPOSITORY } \\
\hline MASS, $m t$ & & & & & 64520 & & & & & & 44679 & 109199 \\
\hline VOLUME, $\mathrm{m} 3$ & & & & & 79234 & & & & & & 13146 & 92380 \\
\hline
\end{tabular}


Table 18. Encapsulation of Shredded Fuel with Glass and Calcine Vitrification, 10 kg U-235 Limit

\begin{tabular}{|c|c|c|c|c|c|c|c|c|c|c|c|c|}
\hline COMPONENT & STREAM 1 & STREAM 2 & STREAM 3 & STREAM 4 & STREAM 5 & STREAM 6 & STREAM7 & STREAM 8 & STREAM 9 & STREAM 10 & STREAM 11 & STREAM 12 \\
\hline mass $\mathrm{kg}$ & 1028904 & 1028904 & & 1028904 & 1028904 & & & & & & & 1028904 \\
\hline VOLUME, $m 3$ & 401 & 241 & & 241 & 241 & & & & & & & 241 \\
\hline mass, $\mathrm{kg}$ & & & & & & & & & & & & \\
\hline VOL.UME, $m 3$ & & & & & & 7421 & & & & & & \\
\hline mass, $\mathrm{kg}$ & & & & & & & 5340912 & 5950000 & 11290912 & & & \\
\hline VOLUME, m3 & & & & & & & 3815 & 4250 & 8065 & & & \\
\hline GLASS-CERAMIC. mass, kg & & & & & & & & & & & & \\
\hline VOLUME, m3 & & & & & & & & & & & & \\
\hline mass, $\mathrm{kg}$ & & & & & & & & & & 34179204 & 34179204 & 34179204 \\
\hline VOLUME, $m 3$ & & & & & & & & & & 13146 & 13146 & 13146 \\
\hline ENCAPSULANT, mass, $\mathrm{kg}$ & & & 444 & 444 & 444 & & & & & & & 444 \\
\hline VOLUME, $m 3$ & & & 171 & 171 & 171 & & & & & & & 171 \\
\hline CANISTERS SNF & & & & & 657 & & & & & & & 657 \\
\hline CALCINE & & & & & & & & & & & & \\
\hline G-C & & & & & & & & & & & & \\
\hline GLASS & & & & & & & & & & & 21000 & 21000 \\
\hline TOTAL & & & & & 657 & & & & & & 21000 & 21657 \\
\hline TOTAL CANISTER WT, $\mathrm{kg}$ & & & & & 328709 & & & & & & 10499878 & 10828587 \\
\hline \multicolumn{13}{|c|}{ TOTAL TO REPOSITORY } \\
\hline MASS, mt & & & & & 1358 & & & & & & 44679 & 46037 \\
\hline VOLUME, $m 3$ & & & & & 411 & & & & & & 13146 & 13557 \\
\hline
\end{tabular}


Table 19. Encapsulation of Shredded Fuel with Glass and Glass-Ceramic Immobilization of Calcine, $0.7 \mathrm{~kg} \mathrm{U}-235$ Limit

\begin{tabular}{|c|c|c|c|c|c|c|c|c|c|c|c|c|}
\hline COMPONENT & STREAM 1 & STREAM 2 & STREAM 3 & STREAM 4 & STREAM 5 & STREAM 6 & STREAM 7 & STREAM 8 & STREAM 9 & STREAM 10 & STREAM 11 & STREAM 12 \\
\hline mass, $\mathrm{kg}$ & 1028904 & 1028904 & & 1028904 & 1028904 & & & & & & & 1028904 \\
\hline VOLUME, m3 & 401 & 241 & & 241 & 241 & & & & & & & 241 \\
\hline mass, $\mathrm{kg}$ & & & & & & & & & & & & \\
\hline VOLUME, m3 & & & & & & 7421 & & & & & & \\
\hline CALCINE & & & & & & & 5340912 & 5950000 & 11290912 & & & \\
\hline VOLUME, $\mathrm{m} 3$ & & & & & & & 3815 & 4250 & 8065 & & & \\
\hline GLASS-CERAMIC. mass, kg & & & & & & & & & & 16000835 & 16000835 & 16000835 \\
\hline VOLUME, m3 & & & & & & & & & & 5000 & 5000 & 5000 \\
\hline mass, $\mathrm{kg}$ & & & & & & & & & & & & \\
\hline VOLUME, m3 & & & & & & & & & & & & \\
\hline ENCAPSULANT, mass, $\mathrm{kg}$ & & & 205383 & 205383 & 205383 & & & & & & & 205383 \\
\hline VOLUME, m3 & & & 78994 & 78994 & 78994 & & & & & & & 78994 \\
\hline CANISTERS SNF & & & & & 126572 & & & & & & & 126572 \\
\hline CALCINE & & & & & & & & & & & & \\
\hline G-C & & & & & & & & & & & 7988 & 7988 \\
\hline GLASS & & & & & & & & & & & & \\
\hline TOTAL & & & & & 126572 & & & & & & 7988 & 134560 \\
\hline TOTAL CANISTER WT, $\mathrm{kg}$ & & & & & 63286071 & & & & & & 3993819 & 67279890 \\
\hline \multicolumn{13}{|c|}{ TOTAL TO REPOSITORY } \\
\hline MASS, $m t$ & & & & & 64520 & & & & & & 19995 & 84515 \\
\hline VOLUME, $m 3$ & & & & & 79234 & & & & & & 5000 & 84234 \\
\hline
\end{tabular}


Table 20. Encapsulation of Shredded Fuel with Glass and Glass-Ceramic Immobilization of Calcine, $10 \mathrm{~kg}$ U-235 Limit

\begin{tabular}{|c|c|c|c|c|c|c|c|c|c|c|c|c|}
\hline COMPONENT & STREAM 1 & STREAM 2 & STREAM 3 & STREAM 4 & STREAM $\mathbf{5}$ & STREAM 6 & STREAM 7 & STREAM 8 & STREAM 9 & STREAM 10 & STREAM 11 & STREAM 12 \\
\hline mass, $\mathrm{kg}$ & 1028904 & 1028904 & & 1028904 & 1028904 & & & & & & & 1028904 \\
\hline VOLUME, m3 & 401 & 241 & & 241 & 241 & & & & & & & 241 \\
\hline mass, $\mathrm{kg}$ & & & & & & & & & & & & \\
\hline VOLUME, m3 & & & & & & 7421 & & & & & & \\
\hline CALCINE & & & & & & & 5340912 & 5950000 & 11290912 & & & \\
\hline VOLUME, m3 & & & & & & & 3815 & 4250 & 8065 & & & \\
\hline GLASS-CERAMIC. mass, $\mathrm{kg}$ & & & & & & & & & & 16000835 & 16000835 & 16000835 \\
\hline VOLUME, $\mathrm{m} 3$ & & & & & & & & & & 5000 & 5000 & 5000 \\
\hline mass, $\mathrm{kg}$ & & & & & & & & & & & & \\
\hline VOLUME, m3 & & & & & & & & & & & & \\
\hline ENCAPSULANT, mass, $\mathrm{kg}$ & & & 444 & 444 & 444 & & & & & & & 444 \\
\hline VOLUME, m3 & & & 171 & 171 & 171 & & & & & & & 171 \\
\hline CANISTERS SNF & & & & & 657 & & & & & & & 657 \\
\hline CALCINE & & & & & & & & & & & & \\
\hline G-C & & & & & & & & & & & 7988 & 7988 \\
\hline GLASS & & & & & & & & & & & & \\
\hline TOTAL & & & & & 657 & & & & & & 7988 & 8645 \\
\hline TOTAL CANISTER WT, $\mathrm{kg}$ & & & & & 328709 & & & & & & 3993819 & 4322527 \\
\hline \multicolumn{13}{|c|}{ TOTAL TO REPOSITORY } \\
\hline MASS, mt & & & & & 1358 & & & & & & 19995 & 21353 \\
\hline VOLUME, m3 & & & & & 411 & & & & & & 5000 & 5411 \\
\hline
\end{tabular}


TABLE 21. DIRECT DISPOSAL SUMMARY

\begin{tabular}{|c|c|c|c|c|}
\hline COMPONENT, $\mathbf{m}^{3}$ & OPTION 1 & OPTION 2 & OPTION 3 & OPTION 4 \\
\hline \multicolumn{5}{|c|}{0.7 KG U-235 LIMIT } \\
\hline SNF & 75,795 & 241 & 241 & 241 \\
\hline CALCINE & 8,065 & & & \\
\hline GLASS-CERAMIC & & & & 5,000 \\
\hline GLASS & & 13,146 & 13,146 & \\
\hline ENCAPSULANT & & 65,848 & 78,994 & 78,994 \\
\hline TOTAL VOLUME, $\mathrm{m}^{3}$ & 83,860 & 79,234 & 92,380 & 84,234 \\
\hline \# CANISTERS & 133,960 & 126,572 & 147,572 & 134,560 \\
\hline \multicolumn{5}{|c|}{10 KG U-235 LIMIT } \\
\hline SNF & 10,934 & 241 & 241 & 241 \\
\hline CALCINE & 8,065 & & & \\
\hline GLASS-CERAMIC & & & & 5,000 \\
\hline GLASS & & 13,146 & 13,146 & \\
\hline ENCAPSULANT & & & 171 & 171 \\
\hline TOTAL VOLUME, $\mathrm{m}^{3}$ & 18,999 & 13,386 & 13,557 & 5,411 \\
\hline \# CANISTERS & 30,350 & 21,384 & 21,657 & 8,645 \\
\hline
\end{tabular}

1. Use of high integrity canisters for direct disposal of SNF and calcine.

2. Encapsulation of shredded fuel with glass and vitrified calcine packaged together.

3. Encapsulation of shredded fuel with glass and vitrified calcine, packaged separately.

4. Encapsulation of shredded fuel with glass and glass ceramic immobilization of calcine.

Given $401 \mathrm{~m}^{3}$ of SNF and $8,065 \mathrm{~m}^{3}$ of calcine (after calcination of existing Na-bearing liquid wastes at low blend ratios), Table 21 summarizes estimated fuel and waste volumes, and canister numbers destined for repository disposal. Option one represents values estimated for direct canning of fuel and calcine as described in Section 4.1. 


\section{Technology Status}

The direct disposal options with preconditioning of fuels and HLW can be broken down into the following five primary processes as shown in Table 22 .

The maturity of technology for fuel shredding and encapsulation is low and will require significant time and resources for development of these processes.

Table 22. Technology Status and Development Issues

\begin{tabular}{||l|l|c||}
\hline \multicolumn{1}{|c|}{$\begin{array}{c}\text { UNIT } \\
\text { OPERATION }\end{array}$} & \multicolumn{1}{|c|}{ ISSUES } & $\begin{array}{c}\text { DEVELOPMENT } \\
\text { TIME }\end{array}$ \\
\hline $\begin{array}{l}\text { Fuel Grinding \& } \\
\text { Shredding }\end{array}$ & $\begin{array}{l}\text { Must achieve maximum volume reduction by shredding. } \\
\text { Number, materials of construction, life, and replacement } \\
\text { costs of shredding equipment must be identified. Develop } \\
\text { means to maintain accountability and material control for } \\
\text { criticality concerns. }\end{array}$ & $12 \mathrm{yr}$ \\
\hline $\begin{array}{l}\text { Calcine } \\
\text { Retrieval }\end{array}$ & $\begin{array}{l}\text { Preliminary pilot-scale retrieval testing has been completed } \\
\text { using simulated calcine materials. Programs are in place for } \\
\text { full-scale mock-up/demonstration tests. }\end{array}$ & $5 \mathrm{yr}$ \\
\hline $\begin{array}{l}\text { Glass } \\
\text { Technology }\end{array}$ & $\begin{array}{l}\text { Laboratory-scale radioactive glass waste forms have been } \\
\text { demonstrated at ICPP. Vitrification has been demonstrated } \\
\text { full-scale at Savannah River and Hanford. Glass processing } \\
\text { of HLW is established technology and has been given Best } \\
\text { Demonstrated Available Technology (BDAT) status by EPA. }\end{array}$ & $5 \mathrm{yr}$ \\
\hline $\begin{array}{l}\text { Glass-Ceramic } \\
\text { Technology }\end{array}$ & $\begin{array}{l}\text { Laboratory-scale glass-ceramic waste form testing has been } \\
\text { conducted on non-radioactive simulated calcine at ICPP. } \\
\text { Programs are in place to verify acceptability of glass-ceramic } \\
\text { waste forms using hot process calcine and develop primary } \\
\text { unit operations. }\end{array}$ & $10 \mathrm{yr}$ \\
\hline $\begin{array}{l}\text { Fuel } \\
\text { Encapsulation }\end{array}$ & $\begin{array}{l}\text { Little work is known to have been completed regarding } \\
\text { encapsulation of SNF. Significant time and energy is } \\
\text { anticipated to develop technology and waste acceptance } \\
\text { specification. }\end{array}$ & $15 \mathrm{yr}$ \\
\hline
\end{tabular}

\subsection{Grout Encapsulation and Greater Confinement Disposal}

The conversion of existing ICPP calcine into a cementitious waste form is, in concept, relatively straightforward. It can be retrieved from the bins and mixed with water and a reducing agent, such as ascorbic acid, to reduce chromate to chromic ion in neutral or moderately basic solutions. The resulting solution can be mixed with an appropriate combination of cementitious solidification agents and then the blended grout can be injected into stainless steel containers. 
These canisters can be designed so that they can subsequently serve as hot isostatic press (HIP) cans later. Hot isostatic pressing will form a glass-ceramic material and reduce the volume by densification.

Existing ICPP calcines can be solidified with a cementitious mix comprised, mainly, of blast furnace slag, microfine silica powder (rice hull ash for example), ferrous sulfide, and a solution of sodium silicate. Processing of sodium-bearing waste requires a somewhat different flowsheet. Before the liquid can be solidified with cement to produce an adequate product, it should first be denitrated and calcined. The calcination process will involve: 1) slurrying the liquid with a mix of existing calcine, adding sugar to facilitate reduction of alkali metal nitrate salts to oxides, and enough silica to convert those oxides to silicates; and 2) feeding the combined slurry to the NWCF. These operations will simultaneously mix, denitrate, and precondition the stream into a product well suited for subsequent cementitious solidification. The dilution of sodium-bearing waste (SBW) with calcine prior to processing in NWCF represents a method to prevent bed agglomeration problems. This will also minimize the amount of additives required both to calcine it and then convert it into final waste forms.

Figure 21 is a process flow diagram of the proposed alternative and Table 23 is a mass balance for the flowsheet. The processing rate is keyed to the maximum anticipated rate at which calcine can be retrieved from the binsets and assumes the combination of all existing calcine with all existing liquid waste.

A more detailed description follows. Calcine can be pneumatically retrieved from the binsets and transferred back to NWCF. There it is slurried with a combined liquid waste consisting of sodium-bearing waste plus process equipment waste bottoms, silica power, and sugar. The mixing tank can then be cooled to prevent premature reaction of the sugar with the nitric acid in the waste. That reaction should occur in the calciner. The slurry is then processed in NWCF at $500^{\circ} \mathrm{C}$ to produce calcine. The calcine is then pneumatically transferred to a surge bin in the grouting facility.

The mercury in the combined waste is recovered form the calciner's offgas by first scrubbing it with nitric acid and then electrowinning it from that solution. This system will collect about 80 grams of mercury per hour.

Particulate contamination can be removed with the NWCF cyclone/scrubber/silica gel/HEPA filter system. The only substantial difference in the composition of the offgas from that generated in the past is that it will contain less $\mathrm{NO}$ and $\mathrm{NO}_{2}$. The sugar additive will reduce most of the nitrate to elemental nitrogen, as well as reduce most of the chromate ion in the original calcine to a less toxic trivalent oxidation state. A fraction of the offgas scrub solution can be continuously recycled into the slurry feed tank.

In the grout facility the calcine is batch mixed with cementitious ingredients consisting primarily of blast furnace slag, ferrous sulfide, and a sodium silicate solution. This mixture is thoroughly 
Table 23. Mass Balance Data For Greater Confinement Alternative

\begin{tabular}{|c|c|c|c|c|c|c|c|c|c|}
\hline \multirow{2}{*}{ Component } & \multirow{2}{*}{ Units } & \multicolumn{8}{|c|}{ Stream Number } \\
\hline & & \#1 & $\# 2$ & \#3 & $\# 4$ & 45 & $\# 6$ & $\# 7$ & $\# 8$ \\
\hline Acid $(\mathrm{H}+)$ & $g / h r$ & 375 & 375 & 81 & & & & & \\
\hline Aluminum (Al) & g/hr & 3,760 & 3,760 & & 33,000 & 36,800 & 8.360 & & 45,100 \\
\hline Americium (Am) & $g / h r$ & 0.00411 & 0.00411 & & & 0.00411 & & & 0.00411 \\
\hline Boron (B) & g/hr & 40 & 40 & & 1,680 & 1,720 & & & 1,720 \\
\hline Cadmium (Cd) & g/hr & 57 & 57 & & & 57 & & & 57 \\
\hline Calcium (Ca) & $\mathbf{g} / \mathbf{h r}$ & 458 & 458 & & 59,500 & 60,000 & 62,900 & & 123,000 \\
\hline Cesium (Cs) & $\mathrm{g} / \mathrm{hr}$ & 0.804 & 0.804 & & & 0.804 & & & 0.804 \\
\hline Chloride (Cl) & g/hr & 216 & 216 & & & 216 & & & 216 \\
\hline Chromium (Cr) & g/hr & 85 & 85 & & & 85 & & & 85 \\
\hline Fluoride (F) & $g / h r$ & 332 & 332 & & 45,500 & 45,800 & & & 45,800 \\
\hline Iron (Fe) & $\mathrm{g} / \mathrm{hr}$ & 361 & 361 & & 433 & 794 & 1,910 & & 2,700 \\
\hline Lead (Pb) & $\mathrm{g} / \mathrm{hr}$ & 66 & 66 & & & 66 & & & 66 \\
\hline Magnesium (Mg) & $\mathrm{g} / \mathrm{hr}$ & & & & & & 13,400 & & 13,400 \\
\hline Manganese (Mn) & $\mathrm{g} / \mathrm{hr}$ & 175 & 175 & & & 175 & & & 175 \\
\hline Mercury (Hg) & $\mathrm{g} / \mathrm{hr}$ & 94 & 94 & & 1,130 & & & & \\
\hline Molybdenum (Mo) & g/hr & 14 & 14 & & & 14 & & & 14 \\
\hline Neptunium (Np) & g/hr & 0.888 & 0.888 & & & 0.888 & & & 0.888 \\
\hline Nickel (Ni) & $g / h r$ & 39.6 & 39.6 & & & 39.6 & & & 39.6 \\
\hline Nitrate $\left(\mathrm{NO}_{3}\right)$ & $\mathrm{g} / \mathrm{hr}$ & 69,600 & 69,600 & 4,960 & & & & & \\
\hline Oxide (O) & $\mathrm{g} / \mathrm{hr}$ & & & & 49,900 & 88,600 & 80,800 & 10,200 & 180,000 \\
\hline Phosphate $\left(\mathrm{PO}_{4}\right)$ & $\mathrm{g} / \mathrm{hr}$ & 221 & 221 & & 195 & 416 & & & 416 \\
\hline Plutonium (Pu) & g/hr & 0.305 & & & & & & & \\
\hline Potassium (K) & $g / h r$ & 1,520 & 1,520 & & 737 & 2,250 & & . & 2,250 \\
\hline Silicon (Si) & $\mathrm{g} / \mathrm{hr}$ & & & & & 11,100 & 34,600 & 7,150 & 52,800 \\
\hline Sodium (Na) & $\mathrm{g} / \mathrm{hr}$ & 7,880 & 7,880 & & 4,190 & 12,100 & & 5,850 & 17,900 \\
\hline Strontium (Sr) & $g / h r$ & 0.61 & 0.61 & & & 0.61 & & & 0.61 \\
\hline Sulfate $\left(\mathrm{SO}_{4}\right)$ & g/hr & 1,100 & 1.100 & & 759 & 1,860 & & & 1,860 \\
\hline Sulfide (S) & $\mathrm{g} / \mathrm{hr}$ & & & & & 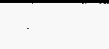 & 1,090 & & 1,090 \\
\hline Technetium (Tc) & $\mathrm{g} / \mathrm{hr}$ & 2.26 & 2.26 & & & 2.26 & & & 2.26 \\
\hline Uranium (U) & g/hr & 20.2 & & & & & & & \\
\hline Zirconium (Zr) & g/hr & 82 & 82 & & 29,700 & 29,800 & & & 29,800 \\
\hline UDS & $\mathrm{g} / \mathrm{hr}$ & 517 & & & & & & & \\
\hline Water $\left(\mathrm{H}_{2} \mathrm{O}\right)$ & $\mathrm{g} / \mathrm{hr}$ & 232,000 & 232,000 & 17,600 & & & & 98,800 & 98,800 \\
\hline TOTAL & $\mathrm{g} / \mathrm{hr}$ & 319,000 & 319,000 & 22,600 & 227,000 & 292,000 & 203,000 & 122,000 & 617,000 \\
\hline
\end{tabular}




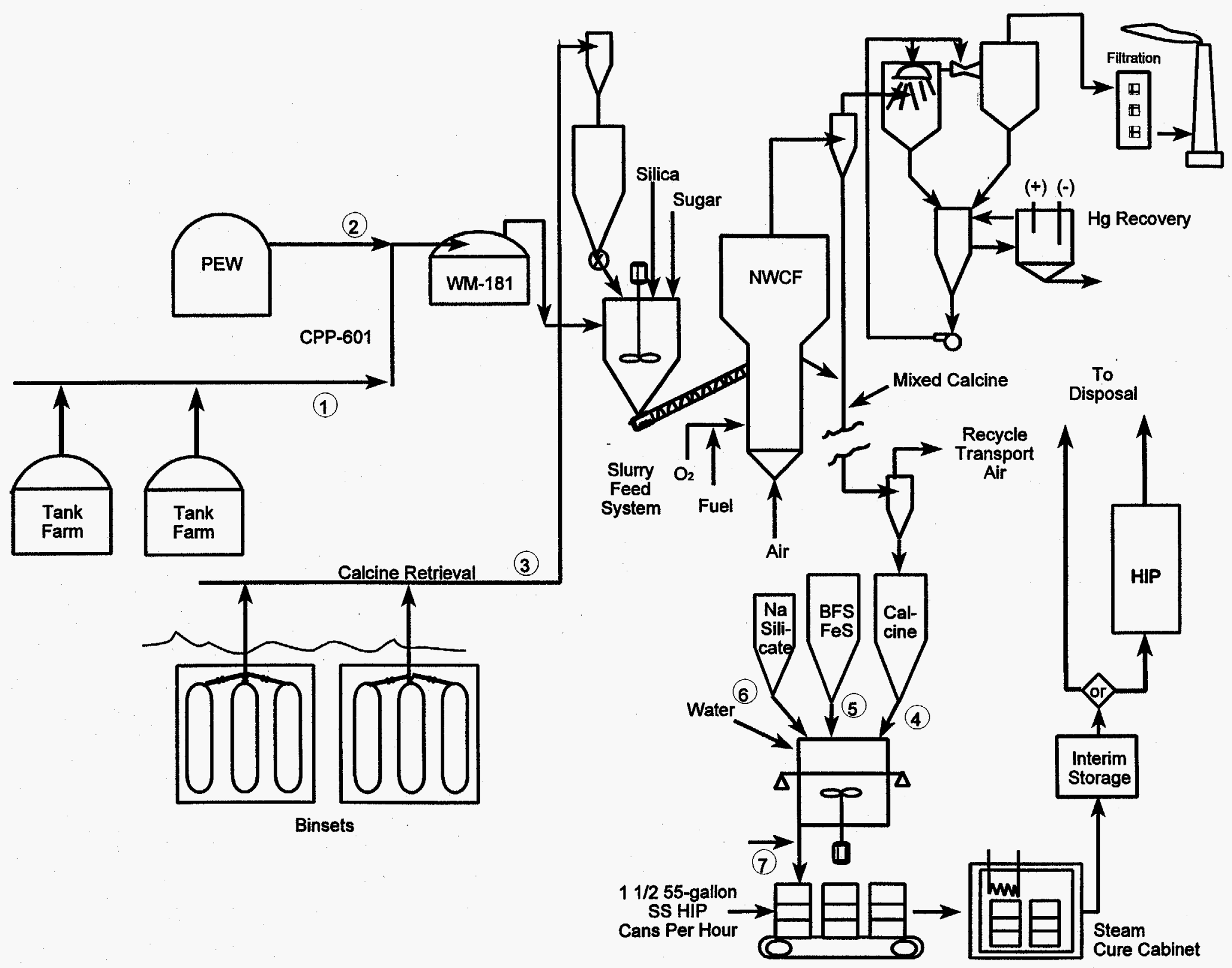

Figure 21. Proposed Grout Encapsulation and Greater Confinement Disposal Process 
blended and injected into stainless steel containers designed to serve subsequently as HIP containers if further treatment is required. The concrete containers are allowed to set for about two hours and then are transferred to a curing cabinet where they are heated for approximately 4 hours with 80-psi saturated steam (about $160^{\circ} \mathrm{C}$ ). Following this, the steam is shut off and a vacuum is pulled on the curing cabinet. This step, formulation under elevated temperature and pressure (FUETAP), removes the concrete's non-chemically combined water, which is done primarily to prevent radiolytic generation of gas. The containers are sealed and transferred to a temporary interim storage facility.

When it becomes necessary to send the waste to the repository, if it is deemed necessary for waste acceptance, the concrete waste forms can then be vitrified by hot isostatic pressing. To accomplish this, the drums are retrieved from the temporary storage facility and transferred to a HIP facility. There they can be vented and heated to approximately $900^{\circ} \mathrm{C}$ to drive off the bulk of the chemically combined water. Following this, the vent tubes are welded shut under vacuum, the drums transferred to a HIP chamber, and the HIPed at $10-20 \mathrm{kpsi}$ and $1000^{\circ} \mathrm{C}$ for 8 hours.

The making of cementitious waste forms from radioactive waste that generates about $40 \mathrm{watt} / \mathrm{m}^{3}$ of heat is a well-established technology elsewhere in the world. Concrete mixing processes have been developed at Sellafield, UK, Oak Ridge National Laboratory, West Valley Demonstration Project, and La Hague, France. The British routinely process rad wastes generating up to 500 watts $/ \mathrm{m}^{3}$ of heat into concrete waste forms. Although a number of mixed calcine simulants have been prepared and solidified with cementitious materials on a laboratory scale here at ICPP, the recipe required for the real mixed-scaled product still needs to be developed and verified using actual waste.

Fluidized-bed waste incineration and combustion systems have been operated commercially for the last twenty-five years. Many of these facilities have feed systems capable of feeding anything from clear liquids to chunks of coal into the combustion bed. Laboratory experiments performed here at ICPP verify that the most efficient way to prevent bed agglomeration problems when calcining high-sodium solutions is simply to dilute it. In view of the fact that the existing calcine needs to be disposed of and is sufficient in both quantity and quality, it appears feasible to use it as the diluent. The addition of fine silica, plus a non-volatile reducing agent such as sugar, to the mix of calcine plus sodium waste liquid prior to calcination will convert the bulk of the sodium and potassium to the respective metasilicate compounds. These compounds are known to be useful in cement-making. The overall concept needs to be developed and tested in one of the ICPP pilot plans or subcontracted to a facility with experience in doing this sort of research.

The process off-gas will contain less $\mathrm{NO}_{\mathrm{x}}$ than has historically been produced. The reduction in $\mathrm{NO}_{\mathrm{x}}$ should not affect the operation of the existing NWCF off-gas cleanup system to any substantial degree. However, the denitration and solidification chemistry will require verification testing and NWCF operating parameters need to be completely evaluated. The scrub tank should be modified to the degree necessary to make the returning of undissolved solids back 
to the calciner feed tank less troublesome than it has been in the past. Mercury will be continuously electroplated from the scrub solution. The electrowinning of mercury from the scrub solution is conceptually and chemically straight forward. But, it does need to be verified and tested on a pilot scale.

The formation of concrete into glass-ceramic with the use of a hot isostatic press will require significant equipment engineering development and the final waste form will require full chemical characterization. 


\subsection{Segregation/Separation Processing Options}

Two overall dispositioning options for ICPP radioactive wastes were illustrated earlier in Figure 2. One would directly dispose of the waste material and the other would segregate or separate radioactive components from the inert materials. This section will discuss and describe options for waste disposal which separate radioactive components from inert components in the spent nuclear fuel, calcine, and sodium-bearing radioactive liquid waste. This is processing which would occur before immobilization of the radioactive materials in a final waste form and transport to a federal repository. The different sections describe two primary methods of treating the waste material. These are pyrochemical and aqueous options. Pyrochemical processing employs high temperature gaseous and molten salt unit operations. These techniques are not presently used within the DOE complex at any significant scale of operation. The aqueous methods are more traditional unit operations, but have been modified to incorporate ideas which are believed to enhance their acceptability within the DOE complex.

\subsection{Aqueous Spent Fuel Processing}

Aqueous chemical processing of SNF for nuclear waste management embodies four major steps: 1.) conversion of spent fuels from solid form to aqueous solution (head-end processes), 2.) separation of fissionable materials, 3.) separation of long-half-life actinides (TRU separation and solidification), and 4.) conversion of aqueous radioactive waste volumes to storable solids for safe, long-term management, as depicted in Figure 22.

\section{Process Descriptions}

The most common method for converting spent nuclear fuels to an aqueous solution suitable for further processing has been acidic dissolution of either part or all of the fuel assembly. At the ICPP, the fuel head-end step has generally required dissolution of the entire fuel assembly: fuel cladding, highly enriched uranium (HEU), fission products, and other fuel components. Two alternatives to acidic dissolution have been included herein, as each has the significant potential for reducing the volume of aqueous dissolver product requiring downstream chemical processing and for reducing the final volume of high-activity, aqueous wastes requiring conversion to solids.

For complete fuel assembly dissolution, the particular acid used has depended upon the fuel cladding compound or alloy, e.g., zirconium, aluminum, stainless steel, etc. As depicted in Figure 23, acidic dissolution of spent nuclear fuels would use processes demonstrated during many years of ICPP operations, e.g., hydrofluoric acid dissolution of zirconium clad naval fuel. Only the HTGR graphite fuel burning and ash dissolution have not been demonstrated fully, but a successful burning process on Rover graphite fuels provides a strong technological basis. Some improvements in these fuel dissolution techniques are possible, but are not expected to be dramatic relative to final waste volumes. 
Spent Nuclear Fuel

Conversion to Aqueous Solutions

- Acidic Dissolution

- Graphite Combustion

- Molten Salt Decladding

- Halide Oxidation Decladdina

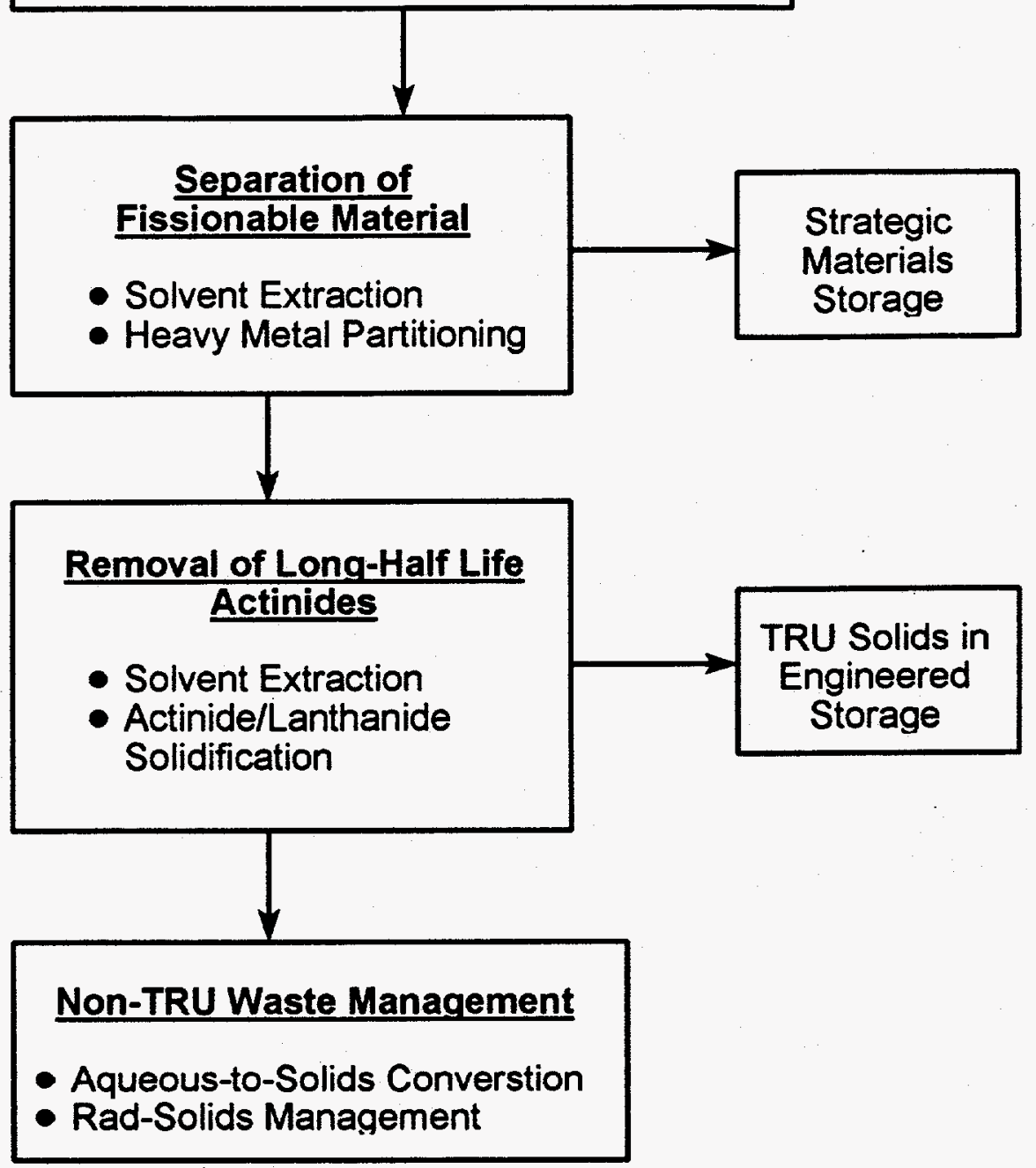

Figure 22. Spent Fuel Dispositioning Aqueous Processing Alternative Primary Process Operations 

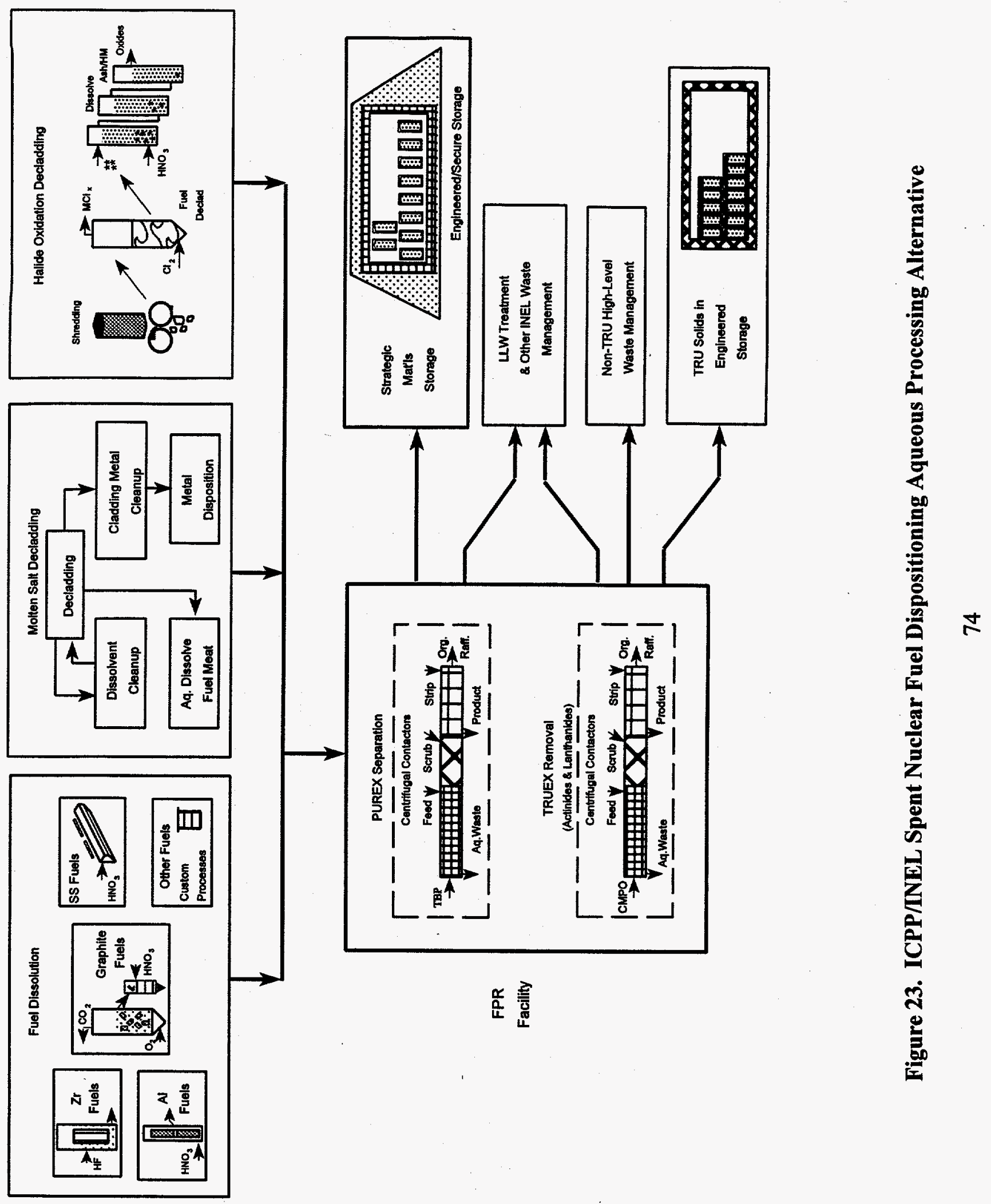
An alternative to the "standard" spent fuel dissolution methods is the decladding of spent fuel using a high temperature molten salt. Molten salt serves as a solvent and as a medium of heat and mass transfer, similar to water in aqueous acid dissolution.

There are three basic molten salt decladding methods: 1) Using the molten salt itself as a dissolvent, 2) dissolution by reagent addition using the molten salt as a heat transfer medium, and 3) using the molten salt as an electrolyte for electrolytic decladding. These three methods are represented by the following examples:

Molten Salt Dissolution: Fuel meat is dissolved from the salt and the salt recovered for recycle. Example:

$$
\begin{aligned}
& \mathrm{Zr}+2 \mathrm{PbCl}_{2}=\mathrm{ZrCl}_{4(\mathrm{~g})}+2 \mathrm{~Pb} \\
& 2 \mathrm{Al}+3 \mathrm{PbCl}_{2}=2 \mathrm{AlCl}_{3(\mathrm{~g})}+3 \mathrm{~Pb}
\end{aligned}
$$

Dissolution by Added Reagent: The salt provides a medium to carry away heat and reaction products. Example:

$\mathrm{NaCl}-\mathrm{MgCl}-\mathrm{KCl}$ mixture @ $380^{\circ} \mathrm{C}$

(Note: $\mathrm{ZrCl}_{4}$ is very soluble when $\mathrm{K}$ is used)

$$
\mathrm{Zr}+2 \mathrm{Cl}_{2}=\mathrm{ZrCl}_{4}
$$

Some chemical material must be added to attack the oxide film if the halide is not a fluoride. $\mathrm{CCl}_{4}$ and $\mathrm{TiCl}_{4}$ are two examples. Fuel material can be recovered by filtration or from a molten metal pool as described below.

Electrolytic Decladding: Cladding metals are transported from the fuel to a cathode, leaving the fuel matrix. A flow schematic and representative cell are shown as Figures 24 and 25 . This method will alleviate the corrosion problems associated with the process by eliminating the strong oxidation reagents. Variations of the method are used in industry to electrorefine metals.

A brief description of an example of the electrolytic decladding follows. After some of the oxide coating has been removed, the whole spent fuel element is then lowered into an anode basket, which rests on a grate immersed in the molten salt anolyte. The basket, constructed from high nickel alloy, is covered by a fine mesh carbon cloth. The voltage is applied across the electrodes and the cladding metal dissolves into the salt. The ions are transferred by the current from the anolyte through the diaphragm and cathode screen to the cathode. The dissolved metal transfers from the catholyte and then is plated onto the removable cathode. When the cathode is fully 


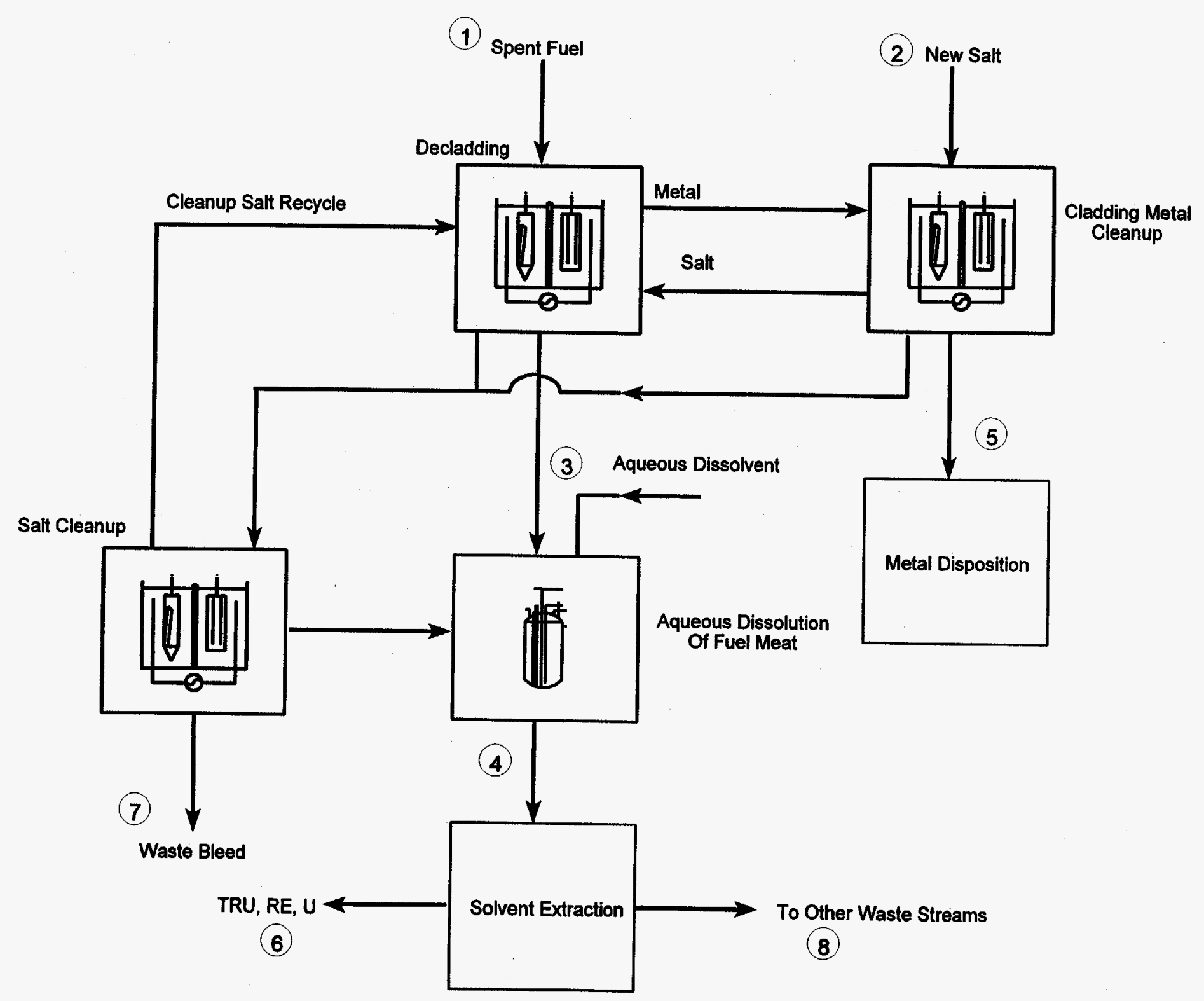

Figure 24. Molten Salt Spent Fuel Decladding 


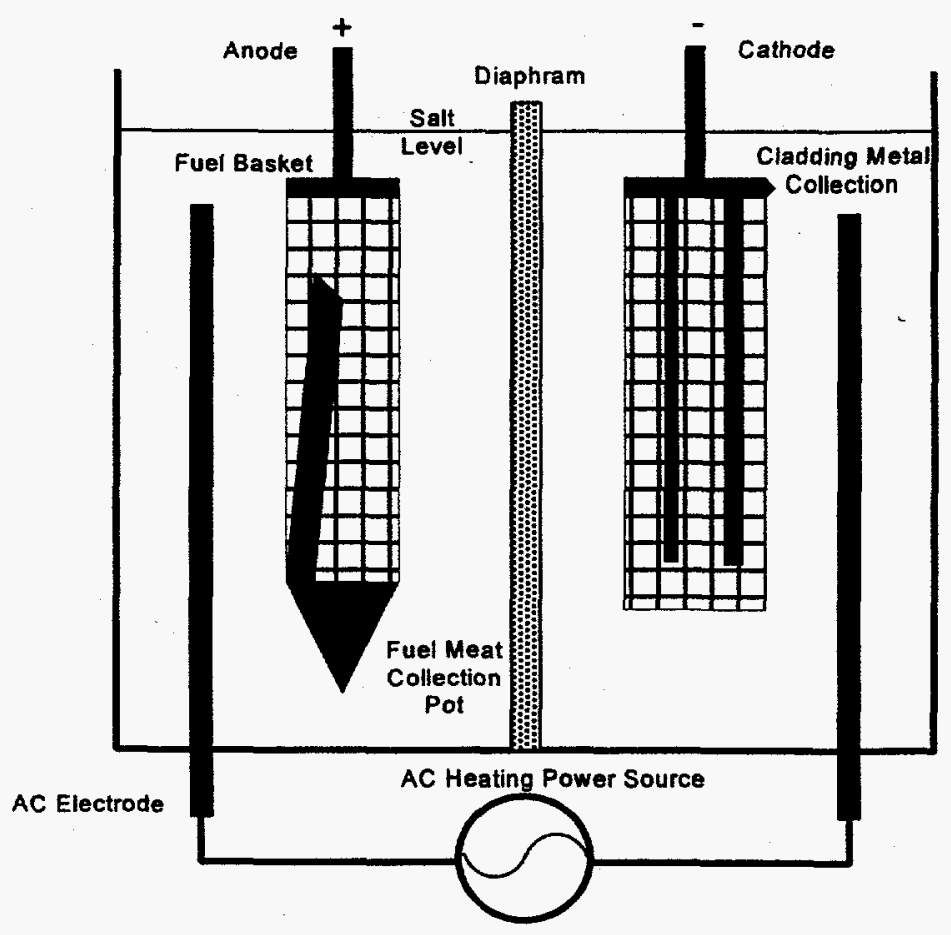

Figure 25. Electrolytic Molten Salt Decladding

loaded it would be transferred to a cleanup cell where the metal will be cleaned by passing it again from anode to cathode. The cleaned cell cathode may be removed, when loaded and stripped of cleaned metal. The cleaned metal may be reused for fuel cladding.

Most fuel material and cladding metal oxides will fall through the anolyte and the decladding cell anode grate into a pool of molten collector tin. The tin is electrically insulated from the main current flow, which protects the cladding material from further attack. The whole collector system will be periodically retrieved from the anode basket, most of the tin will be drained away from the fuel material, and then reused. Undrained tin, fuel material, and cladding metal oxides then are dissolved using an aqueous fluoride flowsheet. The dissolver product will be complexed and transferred to a traditional solvent extraction system.

The molten salt is contained within a metal vessel protected by frozen salt scull (a common industrial practice) which forms on the inside wall, and is maintained at a temperature below the 
resistance heating of the dissolution current and by the $\mathrm{AC}$ heating electrodes.

A salt bleed is used to purge contaminates and as makeup for electrode drag out. This purge is from the least contaminated salt baths to the most. A salt cleanup system is also used to maintain a minimum contamination of radionuclides in the decladding cell salt.

Example: Same salt mixture as above

$$
\begin{array}{ll}
\text { Anode: } & \mathrm{Zr}-2 \mathrm{e}=\mathrm{Zr}^{+2} \\
\text { Cathode: } & \mathrm{Zr}^{+2}+2 \mathrm{e}=\mathrm{Zr}
\end{array}
$$

As depicted in Figure 24, the molten salt will be cleaned and recycled, using methods similar to those proposed for the Integral Fast Reactor (IFR) recycle system. These schemes could be tied to either halide volatility processes or the IFR system.

A halide oxidation and dissolution (HALOX) process alternative would utilize the relatively lowtemperature $\left(500^{\circ} \mathrm{C}\right)$ reaction of chlorine gas with cladding metals to volatilize and remove the bulk of the cladding metals from the fuel meat. This head-end process reduces (by a factor of up to ten) the amount of material to be processed by downstream equipment and may eliminate the use of aqueous fluorides for spent fuel dissolution.

The fuels would be prepared for the chloride burning step by mechanical shredders to reduce the fuel size and increase the surface area for chlorine (or bromine) gas reactions. A simplified schematic of the process is shown in Figure 26. The size-reduced spent fuel would be fed to a fluid bed of alpha alumina particles maintained at about $425^{\circ} \mathrm{C}$. Chlorine (or possibly bromine) would be added, along with an inert fluidization gas. The gas would react with the fuel cladding, forming a volatile metal chloride. Metal chlorides (or bromides) of $\mathrm{Zr}, \mathrm{Fe}, \mathrm{Sn}$ and $\mathrm{Al}$ are volatile above $400^{\circ} \mathrm{C}$. The fuel materials will only partially chlorinate, and the formed species are mostly non-volatile at this temperature, if a slight excess of zirconium is maintained. The alpha alumina bed is not affected at these temperatures and under these conditions.

A filter bank (or a cyclone/filter bank combination) will separate the volatile from the nonvolatile species in off-gas existing the burner. The filtered gases can be raised to $500^{\circ} \mathrm{C}$ while oxygen is added to the off gas. Most of the cladding metal chlorides will be converted to metal oxides, which can be removed from the liberated $\mathrm{Cl}_{2}$ and inert gas by a second bank of filters. $\mathrm{SnCl}_{4}$, if present, can be removed by chilling the gases to below $0^{\circ} \mathrm{C}$.

The remaining off-gas, primarily $\mathrm{Cl}_{2}$ and inerts, can be compressed and stored for recycling to the burner. A gas bleed downstream of the compressor will remove the buildup of fission products in the inert gases. This bleed stream can be treated by compressing and cooling the gas 

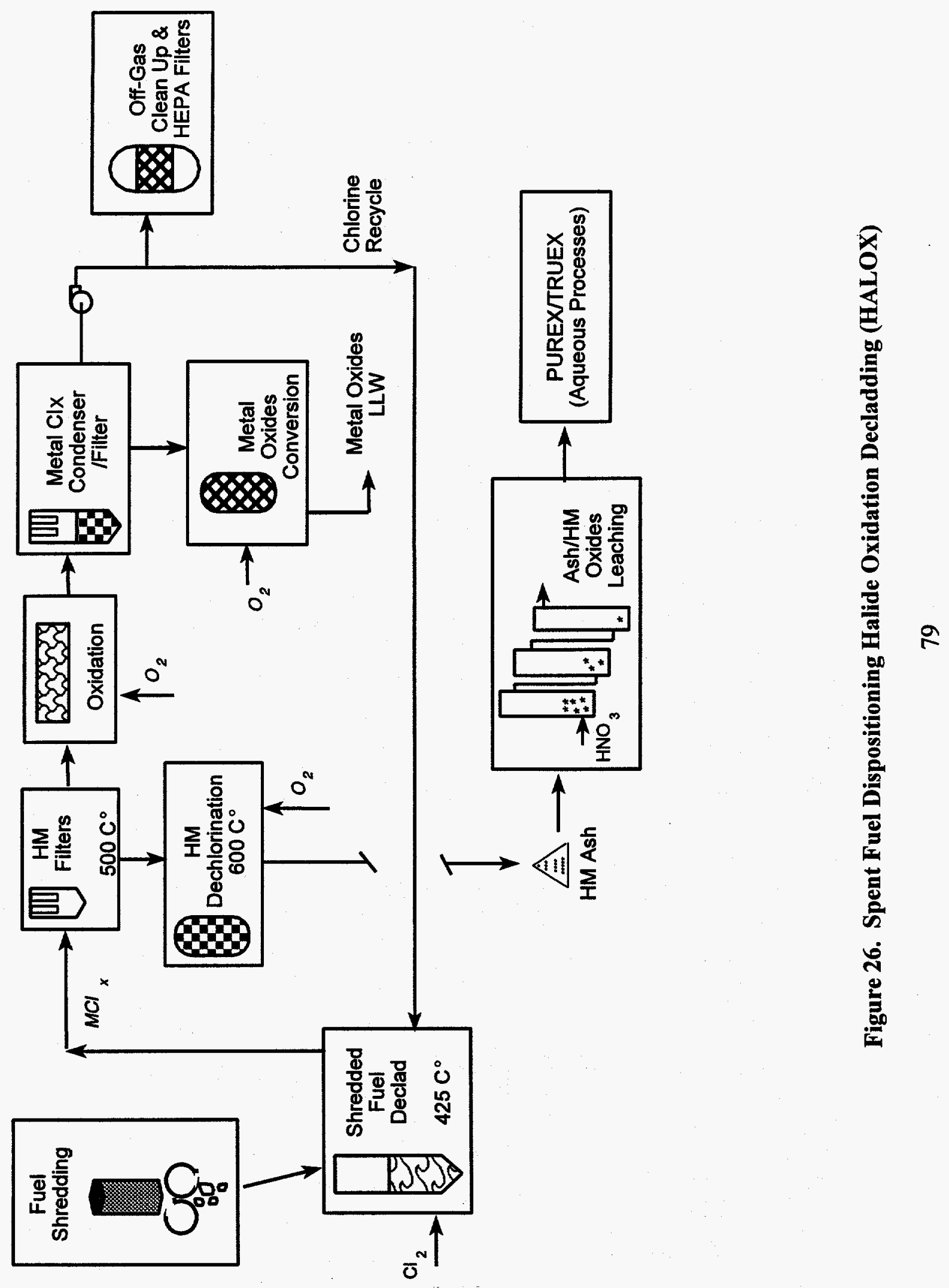
so the chlorine is liquefied and cooled to a low vapor pressure. This effectively removes all the chlorine for return to the burner recycle stream.

Solids from the first filter bank, containing over $97 \%$ of the uranium and all of the TRU, can then be transferred to a dechlorinator vessel and dechlorinated with $\mathrm{O}_{2}$ at $600^{\circ} \mathrm{C}$, and then sent to a dissolver for aqueous processing.

The solids from the secondary filter bank, the cladding metals, can be dechlorinated in a separate vessel, leached with dilute nitric acid, and then dried for storage. The leach solution can then be added to the dissolver product. The slightly contaminated cladding metal oxides might either be used for manufacturing future cladding material or be disposed as low activity solids.

For the burner and high temperature process vessels, a high nickel alloy may be required. The burner will also need an alumina liner for erosion-corrosion resistance. The aqueous equipment should be made of Hastelloy C-22 which resists corrosion by nitric acid containing chlorides.

Some major unresolved questions remain, such as:

1) Control of the burner temperature due to excess $\mathrm{Zr}$ material.

2) Degree of control over the production of volatile $\mathrm{UCl}_{6}$ as opposed to the chlorination of minor cladding metals.

3) The build-up of heavy metals and fission products in the bed.

4) A special filter bank material may be needed due to plugging and corrosion life.

Removal of fissionable material (primarily uranium-235) from dissolver aqueous solution may be required to assure criticality safety in any long-term (decades to centuries or even longer) radwaste storage repository. The fissionable material in spent fuels can be removed by the longestablished plutonium uranium extraction (PUREX) process (using tributyl phosphate as the organic extractant). The process can be significantly upgraded by the use of smaller and more efficient equipment (for example, centrifugal contactors replacing pulse columns or mixer settlers), and thus require a much smaller facility (by a factor of two or three) than previously designed. If alternative decladding methods (described above) are successful, the equipment size requirements could be further reduced by up to another order of magnitude. Process design improvements (increased recycle of low-level activity waste streams) can further decrease the production of low-activity wastes, per unit of fuel processed. A typical process schematic for zirconium dissolver product processing is shown in Figure 27.

A significant advantage gained by the use of centrifugal contactors can be the use of the existing ICPP facilities, and specifically the new Fuel Processing Facility (FPF). Originally intended to 

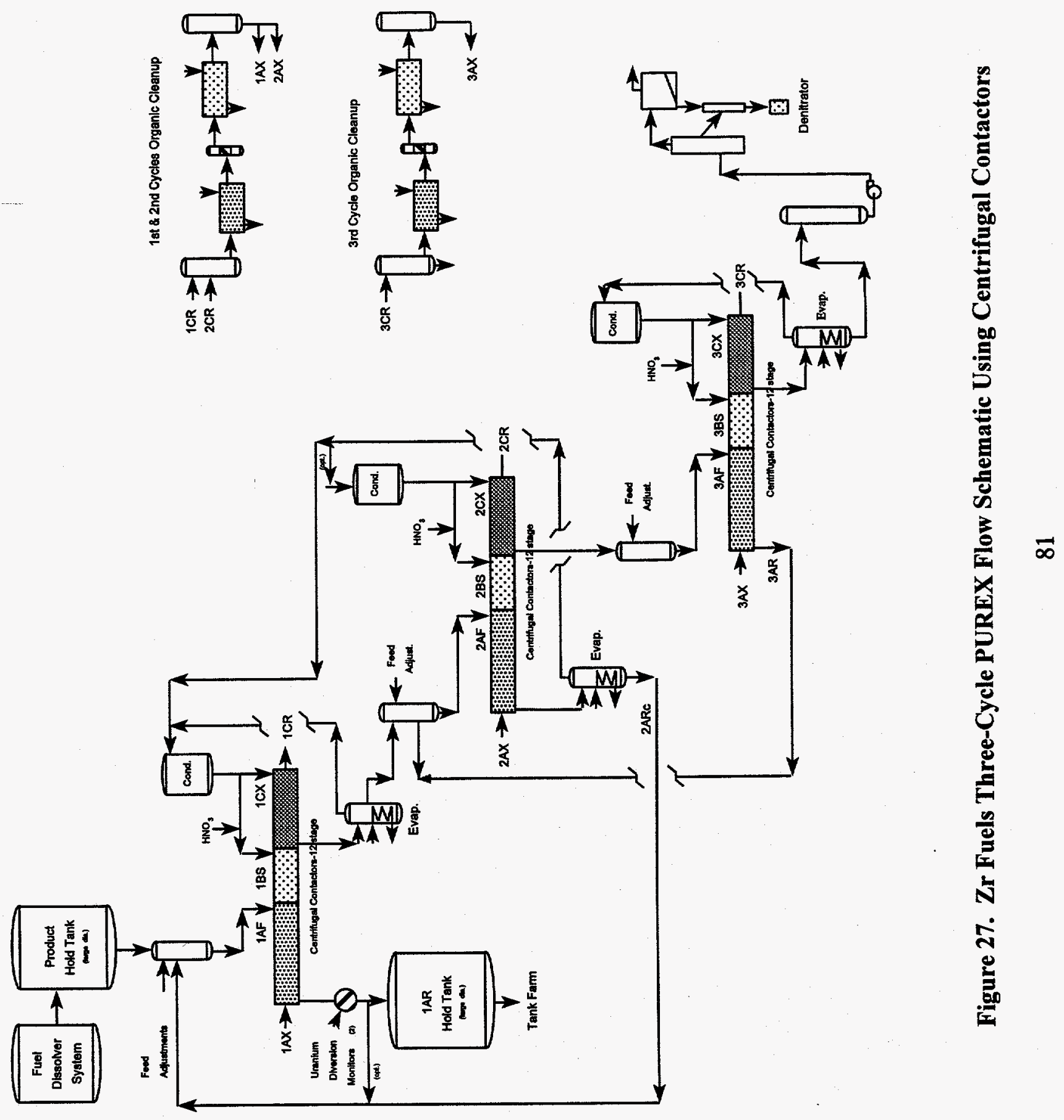
contain a PUREX process based on much larger pulse columns, FPF can contain both the PUREX and TRUEX (see following paragraphs) solvent extraction systems. This can result in a significant cost savings, in the range of several hundred million dollars.

High-activity, radioactive waste from the PUREX process will be further processed into two fractions: one having a high activity, but with relatively short radioactive half lives, and a second having long-lived actinides. The aqueous waste can be processed in a transuranic extraction (TRUEX) solvent extraction system, developed by Argonne National Laboratory. The CMPO solvent has a special affinity for actinides and lanthanides, and is capable of removing them from aqueous streams with such efficiency that the remaining aqueous waste can be classified as nonTRU. The TRUEX process would utilize equipment essentially identical to centrifugal contactors in the PUREX process, only a few additional stages are required for efficient transuranic (TRU) removal. Only a single extraction cycle is required compared to the two, and possibly three, cycles needed for uranium removal and purification. A schematic of a typical TRUEX flowsheet is shown in Figure 28.

Radioactive aqueous wastes resulting from the head-end and solvent extraction operations can be of four general types: TRU, high-activity non-TRU, low activity waste (LAW), and other miscellaneous contaminated materials. The aqueous stream containing the TRU materials can be calcined and emplaced in an engineered storage facility for safe keeping preparatory for transfer to a geologic repository. The non-TRU waste streams either may be calcined directly for storage as a dry solid, or may be further processed for removal of high-activity fission products (e.g., Cs and $\mathrm{Sr}$ ) and calcined as low-level solids. TRUEX processing will reduce the high-activity solids volume requiring geologic-time-scale storage by a factor of approximately 100 , from over 5000 $\mathrm{m}^{3}$ to approximately $50 \mathrm{~m}^{3}$.

For purposes of relative comparison, the projected solid waste volumes resulting from the above spent fuel processing alternatives are summarized in Table 24. As easily observed, the present volume of spent fuel is much larger than the waste volume resulting from aqueous processing methods. However, if only long-lived TRU material is sent for geologic disposal, the process volumes are lower by a factor greater than ten. The storage location for "long-term" storage of remaining high-activity, but non-TRU, waste is no more easily identified than will HEU storage at some geologic site. The relative difference of waste volume, as they appear in Table 24 from the various process head-end steps, appears to be noticeable, but they are not necessarily significant due to the assumptions made listed in Section 2.0. The TRU volume does not change. The significance of the other rad wastes does depend on their final storage location, which in turn determines the cost impact. 


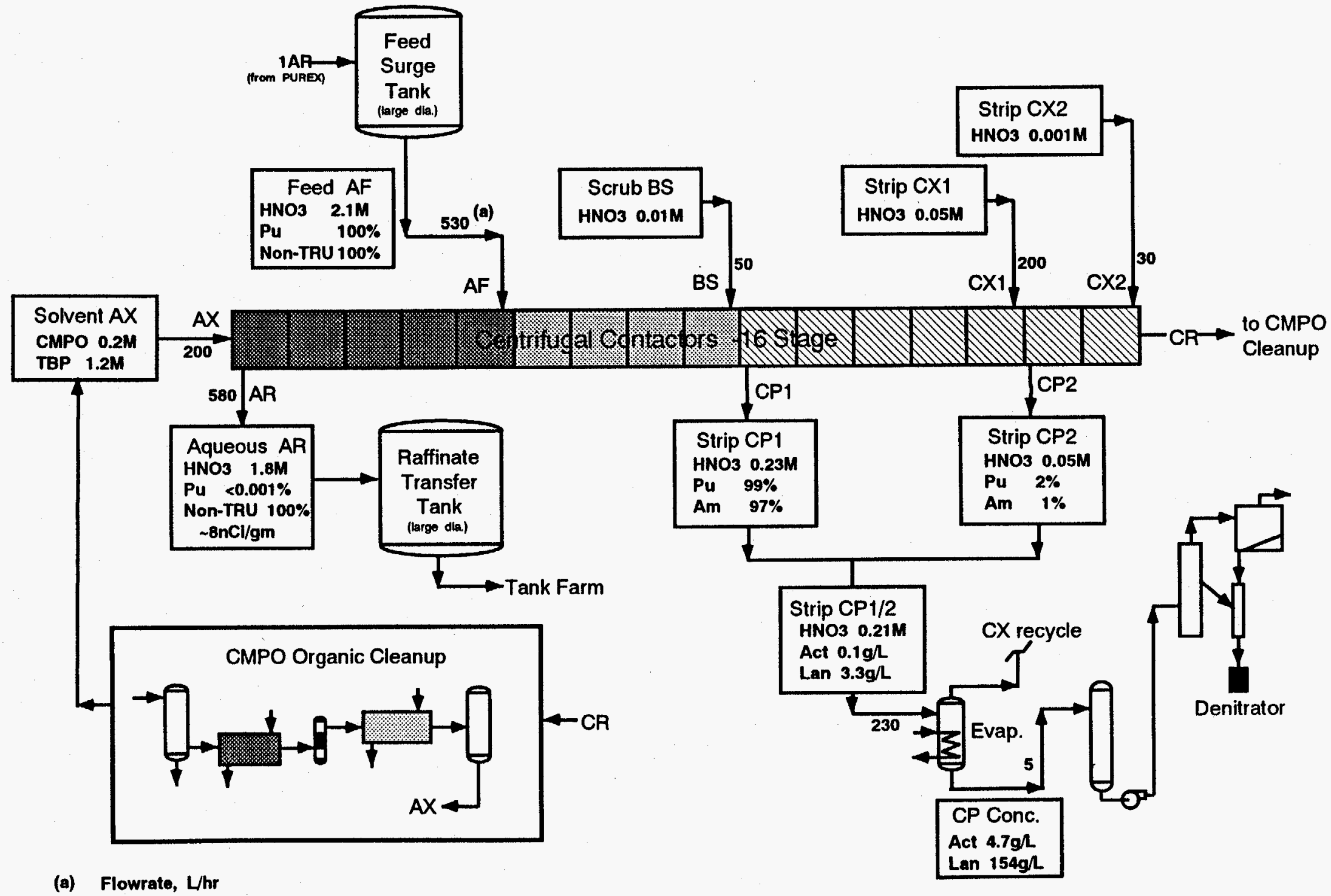

Figure 28. Typical TRUEX Flow Schematic Using Centrifugal Contactors 
Table 24. Comparison of Waste Volumes

Resulting from the Spent Fuel Process Alternatives

\begin{tabular}{||l|l|l|l|l||}
\hline \multicolumn{2}{|c|}{ Waste Volumes $^{\mathrm{a}}, \mathbf{m}^{3}$} \\
Alternatives & $\begin{array}{l}\text { TRU } \\
\text { w/HEU }\end{array}$ & $\begin{array}{l}\text { TRU } \\
\text { w/o HEU }\end{array}$ & Non-TRU' & Other \\
\hline $\begin{array}{l}\text { Spent Fuel (Fuel } \\
\text { Receipts through } \\
\text { 2015) }\end{array}$ & 760 & na & TBD & TBD \\
\hline $\begin{array}{l}\text { Processing (w/PUREX } \\
\text { \& TRUEX) }\end{array}$ & & & 5100 & 5000 \\
\hline Fuel Dissolution & na & 45 & 1700 & 4500 \\
\hline $\begin{array}{l}\text { Molten Salt } \\
\text { Decladding }\end{array}$ & na & 45 & 1400 & 2500 \\
\hline $\begin{array}{l}\text { Chloride Oxidation } \\
\text { Decladding }\end{array}$ & na & 45 & & \\
\hline
\end{tabular}

a. Note that volume/area/canisters in a geologic repository may not be related similarly to the relative values above. The repository may require additional area/volume to accommodate issues of criticality safety, transportation container, and number of canisters. This would be particularly true for HEU-bearing spent fuel volumes estimated above.

b. Engineered storage until transport to geologic repository

c. Calcined as high-activity, non-TRU, solid waste

d. Low-level contaminated materials transported to INEL RWMC

\section{Technology Status}

With few exceptions, the aqueous processing of spent fuels for waste management uses demonstrated technology, processes, and equipment. The exceptions, although important, are not considered significant, as alternate methods are available. For purposes of relative comparison, the primary process steps are listed in Table 25 on technology, development requirements, and facility needs.

The molten salt process carries the greatest technical risk and the longest development time. Using proven fuel dissolution approaches provides the lowest risk and development, but may not provide the optimum waste volume management. The new halide oxidation and dissolution (HALOX) concept uses a mixture of old and relatively new technology. This suggests that a significant waste volume reduction is possible, without requiring a large technical risk and excessive development periods. 
Table 25. Relative Comparison of Aqueous Process Alternatives

\begin{tabular}{|c|c|c|c|c|c|}
\hline \multicolumn{6}{|c|}{ UNIT OPERATIONS -- IMPLEMENTATION TIME (YRS) } \\
\hline PROCESS STEP & $\begin{array}{l}\text { Laboratory } \\
\text { Research }\end{array}$ & $\begin{array}{l}\text { Lab/PP } \\
\text { Testing }\end{array}$ & $\begin{array}{c}\text { Pilot Plant } \\
\text { Demonstration }\end{array}$ & $\begin{array}{c}\begin{array}{c}\text { Design \& } \\
\text { Construction }\end{array} \\
\end{array}$ & $\begin{array}{l}\text { Operation } \\
\text { Initiated }\end{array}$ \\
\hline Molten Salt Decladding & 2 & 3 & 2 & $.12-15$ & 20 \\
\hline Halide Oxidation Declad & 2. & 2. & 2. & 8-12. &. .16 \\
\hline \multicolumn{6}{|l|}{ Aqueous Headends: } \\
\hline Zirconium & NA & NA & NA & NA. & NA \\
\hline Aluminum & NA & NA. & NA & إ... & ...!! \\
\hline Stainless Steel & NA & NA. & NA. & U!... & (l). \\
\hline Graphite & NA & $\mathrm{NA}$ & 4 & $12-15$ & 15 \\
\hline Custom & !ي...... & إي.. & !ي!. & (u! & !) \\
\hline PUREX & $\mathrm{NA}$ & NA & NA. & 10. & 10 \\
\hline TRUEX & $\mathrm{NA}$ & NA & 2 & 10 & 12 \\
\hline TRUEX Solidification & 1 & 1. & .1 & 10 & 12. \\
\hline \multicolumn{6}{|l|}{ Waste Management (Alts): } \\
\hline Grout & Unk. & Unk. & Unk. & Unk & Unk. \\
\hline \multirow[t]{2}{*}{ NWCFMMF } & ..........nnk.. & Unk. & Unk.... & 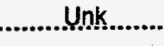 & ........ Unk \\
\hline & Unk - Unknow & UI-Unidentified & NA-Not Applic & & \\
\hline
\end{tabular}

\begin{tabular}{|c|c|c|c|c|c|}
\hline \multicolumn{6}{|c|}{ UNIT OPERATIONS -- FACILITY REQUIREMENTS } \\
\hline PROCESS STEP & $\begin{array}{l}\text { Laboratory } \\
\text { Research }\end{array}$ & $\begin{array}{l}\text { Lab/PP } \\
\text { Testing }\end{array}$ & $\begin{array}{c}\text { Pilot Plant } \\
\text { Demonstration }\end{array}$ & $\begin{array}{c}\begin{array}{c}\text { Design \& } \\
\text { Construction }\end{array} \\
\end{array}$ & $\begin{array}{l}\text { Operation } \\
\text { Initiated }\end{array}$ \\
\hline Molten Salt Deciadding & CPP-637. & . UI! & UI & U! & U!.... \\
\hline Halide Oxidation Declad & CPP-637 & CPP-637. & Now Plotrats & U! & 胃! \\
\hline \multicolumn{6}{|l|}{ Aqueous Headends: } \\
\hline Zirconium & NA. & NA. & NA. & NA & (r. \\
\hline Aluminum & NA. & NA. & NA. & 10, eratory & 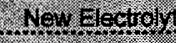 \\
\hline Stainiess Steel & NA. & NA. & NA & 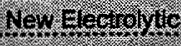 & rey encrioly \\
\hline Graphite & NA. & NA. & Now Pind Prast & $0.26 \%$ & 0.1 .1 .26 \\
\hline Custom & CPP-637 & NA. & NA & Jeyuluigune & Nowmulsery \\
\hline PUREX & NA. & NA. & NA. & ther & 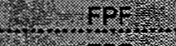 \\
\hline TRUEX & U! & CPP-637. & CPP.637. & (c) & $\operatorname{tg} 8$ \\
\hline TRUEX Solidification & CPP-637. & CPP-637. & CPP-63? & $x_{1}^{2}=$ & 2 \\
\hline \multicolumn{6}{|l|}{ Waste Management (Alts): } \\
\hline Grout & U!... & . & U! & UI & U! \\
\hline \multirow[t]{2}{*}{ NWCFMIF } & 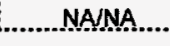 & NAMCPP_637....... & NowexPR & NANow & 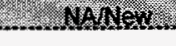 \\
\hline & Unk - Unknow & UI-Unidentified & NA-Not Applic & & \\
\hline
\end{tabular}

\begin{tabular}{|c|c|c|c|c|c|}
\hline \multicolumn{6}{|c|}{ UNIT OPERATIONS -- TECHNICAL MATURITY } \\
\hline PROCESS STEP & $\begin{array}{l}\text { Laboratory } \\
\text { Research }\end{array}$ & $\begin{array}{l}\text { Lab/PP } \\
\text { Testing }\end{array}$ & $\begin{array}{c}\text { Pilot Plant } \\
\text { Demonstration }\end{array}$ & $\begin{array}{c}\begin{array}{c}\text { Design \& } \\
\text { Construction }\end{array} \\
\end{array}$ & $\begin{array}{l}\text { Operation } \\
\text { Initiated }\end{array}$ \\
\hline Molten Salt Decladding & Conceptual & None. & None. & None. & None. \\
\hline Halide Oxidation Declad & Conceptual & Partial & None. & None. & None. \\
\hline \multicolumn{6}{|l|}{ Aqueous Headends: } \\
\hline Zirconium & Yes. & Yes. & Yes. & Yes. & Yes.... \\
\hline Aluminum & Yes. & Yes.(Hg vs HBF4). & Yes. & Yes & Yes \\
\hline Stainless Steel & Yes. & Yes & Yes. & Yes............... & Yes \\
\hline Graphite & Yes. & Yes. & Incomplete. & Conceptual. & None. \\
\hline Custom & Conceptual & Incomplete. & None. & None & None. \\
\hline PUREX & Yes & Yes & Yes. & Yes. & Yes. \\
\hline TRUEX & Yes. & Yes & None. & None... & None. \\
\hline TRUEX Solidification & Conceptual & None. & None. & None. & None. \\
\hline \multicolumn{6}{|l|}{ Waste Management (Alts): } \\
\hline Grout & Incomplete & None. & None. & None. & None... \\
\hline \multirow[t]{2}{*}{ NWCFMIF } & Yes/Yes. & Yess/Partial. & Yes/Nonne.... & .....Yess:Nones... & Yess/None \\
\hline & Unk - Unknou & UI-Unidentified & NA-Not Applic & & \\
\hline
\end{tabular}


Two or three significant issues associated with each head-end and processing concept are listed below:

Acid Fuel Dissolution:

- Low technical risk, as it uses proven and demonstrated technology

- Overall volumes of non-TRU waste are large, but conversely much smaller volumes of TRU waste can be managed for geologic time periods.

Molten Salt Decladding:

- $\quad$ Reduced volumes of non-TRU cladding and process wastes.

- $\quad$ No change in TRU waste volumes, and no significant change in low-activity waste volume.

Technical risk significant, as the application of molten salt to nuclear requirements on the scale needed is new and untried.

Halide Oxidation Decladding:

- $\quad$ Shredding technology is well established and widely used. Although untried in shredding spent fuel, the breadth of available industrial applications easily encompasses the planned application.

- $\quad$ Halide oxidation for fuel decladding is untried, but appears applicable. Development is required and risks appear manageable. Materials of construction may be unique in the nuclear industry, but are not in commercial enterprises.

- Fuel dissolution techniques appear to be standard and have been previously demonstrated.

PUREX Separation:

- $\quad$ Proven technology worldwide in many production scale facilities.

- Use of centrifugal contactors has been well developed in the laboratory, with some use in industrial scale facilities.

- $\quad$ May use the nearly completed FPF facility, for example no new facility construction is envisioned. 
TRUEX Removal:

- Laboratory development has been extensive.

- Industrial scale applications have not been constructed or operated.

May be installed in existing FPR cells without interfering with preceding PUREX requirements.

High-Activity, Non-TRU, Waste Management:

- Short half-lives would assure that all non-TRU fission products decay and disappear within 500-700 years, such as geologic disposal not deemed mandatory.

- This is a significant issue for waste form disposal site consideration.

TRU Waste Management:

- Calcination of TRU liquids to solids has not been demonstrated and would require remote handling.

- Engineered, interim storage will be required until transfer to a geologic repository.

Low-Activity Waste Management:

All processing alternatives will produce quantities of low-activity, low concentration rad-waste.

- Off-site shipment to a repository will be highly expensive compared to safe onsite management. 


\subsection{Pyrochemical Spent Fuel Processing}

Dry halide spent fuel conditioning is a conceptual non-aqueous process for separating the components of SNF by volatilizing them as chlorides then recovering the fission product (FP) and transuranic (TRU) chlorides in a molten salt scrubber. The inert and fissile components will also be collected in downstream condensers. The process is flexible in that it can accommodate many types of fuel, such as: Zircaloy fuels, aluminum fuels, stainless steel fuels, and commercial LWR oxide fuels. Graphite fuels may be processed after the graphite matrix has been burned off.

\section{Process Description}

The flowsheets presented here do not include a specific concept for further separation of the FPs from the TRUs, but indicate a conversion of the small quantity of combined FP-TRU HLW into a waste form for repository disposal. Options such as TRUEX can be applied to the FP- and TRU chlorides if further separation is desired or needed.

The dry halide processing concept consists of four major unit operations as shown in Figure 29, which are:

- Chlorination: chlorination and volatilization of all fuel components will occur at approximately $1500 \mathrm{~K}$.

- $\quad$ Molten salt scrubber: fission product (FP)-, transuranic (TRU)-, Ni-, and Crchlorides can be removed by both condensation and dissolution in the melt at about $673 \mathrm{~K}$.

-

Fractional condensation: three condensers would be used to remove $\mathrm{ZrCl}_{4}, \mathrm{FeCl}_{3}$, $\mathrm{AlCl}_{3}, \mathrm{UCl}_{6}, \mathrm{SnCl}_{4}$, and $\mathrm{I}_{2}$ vapors that pass through the scrubber, at temperatures ranging from 437 to $275 \mathrm{~K}$.

- Molten salt regeneration/fluorination: the spent molten salt would be transferred and vacuum distilled to recover $\mathrm{ZnCl}_{2}$ and $\mathrm{ZnCl}_{2}$-soluble $\mathrm{ZrCl}_{4}$ for recycle to the scrubber leaving the FP-, TRU-, Ni-, and $\mathrm{Cr}$-chlorides as residue, which will then be converted to oxides or fluorides for vitrification.

Argon carrier gas and unreacted chlorine gas can be recycled, the $\mathrm{Cl}_{2}$ content adjusted, and the stream split and passed through the unit operations in a continuous closed loop. Periodic shut down of the coupled unit operations will occur for batch removal of fission product $\mathrm{Xe}$ and $\mathrm{Kr}$ gases from the carrier gas, batch transfer of the molten salt to the molten salt regenerator, and batch removal of radiologically inert materials and fissile products from the condensers. 
The general unit operation descriptions and assumptions are provided in detail for Zircaloy fuels because they represent the most stringent fuels in terms of general requirements. These requirements concern heat generation and types of components that must be treated. Any changes necessary for the processing of other fuel types are provided in subsequent sections. Graphite fuels are not specifically discussed. Flowsheet and mass balance descriptions are also not provided for commercial LWR fuels, the composition of which is described in Section 2.1 for reference and comparison to other fuels considered. Application of the chloride volatility process to them would be after the process has been developed for DOE fuels; thus, detailed considerations are not presented at this time. The main difference for the LWR fuels would be the quantity of oxygen scavenger involved. $\mathrm{A} \mathrm{CO}_{2}$ removal bed in the recirculating off-gas system is indicated in Figure 29 on the premise that $\mathrm{CO}$ would be the oxygen scavenger, and this would be a more major unit operation for the LWR fuels than for others.

To calculate product distributions and product rates given in the material balance spreadsheet, it is assumed that thermodynamic equilibrium can be instantaneously achieved in the chlorination reactor, that the rate of chlorination can be controlled by the rate of chlorine addition to the spent fuel, and that a gas-condensed phase equilibrium will exist in the downstream scrubber and condensers. It is also assumed that about three fourths of the chlorine will contact the fuel and react as it passes through the reactor.

Selection of a process flowrate is somewhat arbitrary, but based on historical and planned processing rates at the ICPP, a process rate of 1.25 Zircaloy FHUs/day is selected for sizing processing equipment and providing the throughput basis for all fuels. An FHU (fuel handling unit) is defined as the equivalent of a batch charge in an ICPP Fluorinel Dissolution Process (FDP) dissolver during its operation. The top part of the mass balance flowsheet (Table 26) provides feed and products rates based on the process rate while the bottom part of the spreadsheet provides the same information in $\mathrm{kmol} / 100 \mathrm{~kg}$ of fuel processed.

\section{Specific Unit Operations for Zircaloy Fuels}

The mass balance flowsheet is shown in Table 26. The Zircaloy fuel flow diagram is shown in Figure 29. They are for naval fuels that do contain stainless steel, to bracket the compositions. About 75 percent of the fuels that would be processed do not contain stainless steel. 


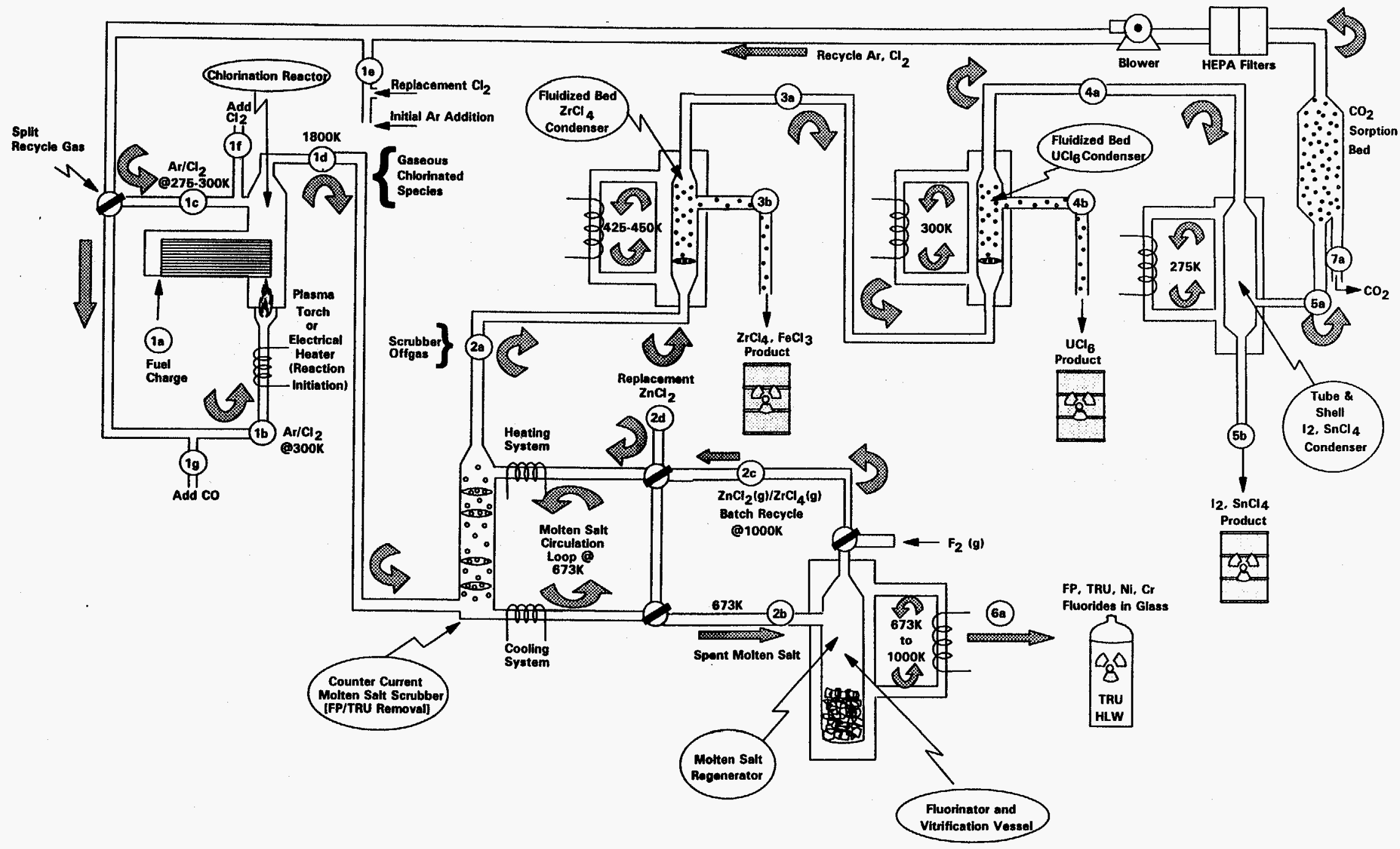

Figure 29. Proposed Pyrochemical Processing of SNF 
Table 26. Mass Balance for Pyrochemical Processing of Zircaloy Fuels

\begin{tabular}{|c|c|c|c|c|c|c|c|c|c|c|c|c|c|c|c|c|c|}
\hline \multirow{2}{*}{$\begin{array}{l}\text { Unit Operation } \\
\text { Stream Number }\end{array}$} & \multicolumn{6}{|c|}{ Chlorination Reactor } & \multicolumn{4}{|c|}{ Molten Salt Scrubber } & \multicolumn{2}{|c|}{ ZrCl4 Condenser } & \multicolumn{2}{|c|}{ UC/6 Condenser } & \multicolumn{2}{|c|}{ SnCl4 Condenser } & \multirow{2}{*}{$\begin{array}{c}T R U / A L W \cdot C l \\
6 a \\
\end{array}$} \\
\hline & $\overline{1 a}$ & 16 & $1 c$ & 10 & 1 & $1 f$ & $2 a$ & $2 b$ & $2 c$ & $2 d$ & $3 a$ & $3 b$ & $4 a$ & $4 b$ & $5 a$ & $5 b$ & \\
\hline Feed/Product Rates (kmo/h) & $2.17 \mathrm{e}-01$ & & & & $1.05 \mathrm{e}-02$ & $4.08 \mathrm{e}-01$ & & & & $2.200-03$ & & $2.03 e-01$ & & $3.690-03$ & & $2.250-03$ & $2.13 e-03$ \\
\hline Temperature & ambient & 300 & 300 & 1800 & 300 & 300 & 673 & 673 & 1010 & 673 & 437 & 437 & 300 & 300 & 275 & 275 & 1000 \\
\hline Gas Flow ( $m 3 / h @ S T P$ ) & & 56.9 & 14.2 & 75.6 & 0.2 & $9.15 \mathrm{e}+00$ & 75.6 & Liquid & Gas & Liquid & 70.8 & Solid & 70.8 & Solid & 70.8 & $\mathrm{Liq} / \mathrm{Sol}$ & Liquid \\
\hline Gas Flow(m3h@ Temo\& 1ATM & & 62.5 & 15.6 & 498.5 & 0.3 & $1.01 \mathrm{e}+01$ & 186.4 & Batch & Batch & Batch & 113.4 & Batch & 77.8 & Batch & 71.4 & Batch & Batch \\
\hline \multicolumn{18}{|l|}{ Components (kmol/100kg fuel) } \\
\hline Total & $1.10 \theta+0$ & $1.29 \theta+01$ & $3.22 \mathrm{e}+\infty 0$ & $1.71 \theta+01$ & $5.30 \theta-02$ & $2.07 e+00$ & $1.710+01$ & & & & $1.60 \mathrm{e}+01$ & & $1.600+01$ & & $1.60 \theta+01$ & & \\
\hline $\operatorname{Ar}(g)$ & & $1.000+01$ & $2.500+00$ & $1.25 \theta+01$ & & & $1.25 \theta+01$ & & & & $1.25 e+01$ & & $1.25 \theta+01$ & & $1.25 \mathrm{e}+01$ & & \\
\hline$c / 2(\sigma)$ & & $2.87 \theta+00$ & $7.17 e_{-01}$ & $3.530+00$ & $5.300-02$ & $2.07 e+00$ & $3.530+00$ & & & & $3.530+00$ & & $3.53 e+00$ & & $3.53 \mathrm{a}+00$ & & \\
\hline$Z r(s)$ & $9.98 e-01$ & & & & & & & & & & & & & & & & \\
\hline $\mathrm{ZrO2(s)}$ & $9.600-03$ & & & & & & & & & & & & & & & & \\
\hline $\mathrm{ZrCl} / 4(\mathrm{~g})$ & & & & $1.01 \theta+00$ & & & $1.010+00$ & & & & $6.058-03$ & & & & & & \\
\hline $2 \mathrm{rCl} / 4(\mathrm{~s})$ & & & & & & & & & & & & $1.00 e+00$ & & $6.04 \mathrm{e}-03$ & & & \\
\hline$U(s)$ & $7.700-03$ & & & & & & & & & & & & & & & & \\
\hline$U C 16(g)+U c 15(g)+U C 14(g)$ & & & & $7.700-03$ & & & $7.700-03$ & & & & $7.700-03$ & & $1.54 \theta-05$ & & & & \\
\hline ucl6(s) & & & & & & & & & & & & & & $7.68 \mathrm{e}-03$ & & $1.54 \mathrm{e}-05$ & \\
\hline $\operatorname{sn}(s)$ & $1.140-02$ & & & & & & & & & & & & & & & & \\
\hline $\operatorname{SnCl4(g)}$ & & & & $1.14 \theta-02$ & & & $1.14 \theta-02$ & & & & $1.14 \mathrm{e}-02$ & & $1.14 \theta-02$ & & & & \\
\hline SnCl4(n) & & & & & & & & & & & & & & & & $1.14 \mathrm{e}-02$ & \\
\hline $\mathrm{Fe}(\mathrm{s})$ & $2.00 \mathrm{e}-02$ & & & & & & & & & & & & & & & & \\
\hline $\mathrm{FeC} / 3(g)$ & & & & $2.000-02$ & & & $\begin{array}{ll}2.00 e-02 \\
\end{array}$ & & & & \begin{tabular}{|l|}
$5.000-03$ \\
\end{tabular} & & & & & & \\
\hline $\mathrm{FeCl} / 3(\mathrm{~s})$ & & & & & & & & & & & & $1.50 \mathrm{e}-02$ & & $5.00 \mathrm{e}-03$ & & & \\
\hline $\mathrm{Cr}(s)$ & $6.90 \mathrm{e}-03$ & & & & & & & & & & & & & & & & \\
\hline $\mathrm{CrCl3(g)}$ & & & & $6.900-03$ & & & & & & & & & & & & & \\
\hline $\mathrm{CrCl} / 3(\mathrm{~s})$ & & & & & & & & $6.900-03$ & & & & & & & & & $6.900-03$ \\
\hline $\mathrm{Ni}(s)$ & $3.800-03$ & & & & & & & & & & & & & & & & \\
\hline NiCl2(g) & & & & $3.800-03$ & & & & & & & & & & & & & \\
\hline NiCli2(s) & & & & & & & & $3.800-03$ & & & & & & & & & $3.800-03$ \\
\hline $\mathrm{ZnCl} / 2(1) / \mathrm{ZrCl} 4(1)$ & & & & & & & & $1.720-01$ & & & & & & & & & \\
\hline $\mathrm{ZnCl} / \mathrm{g}(\mathrm{g} / \mathrm{ZrCl} / 4(\mathrm{~g})$ & & & & & & & & & $1.72 \theta-01$ & & & & & & & & \\
\hline $\mathrm{ZnCl}(\mathrm{g})$ & & & & & & & $1.12 \theta-02$ & & & & & & & & & & \\
\hline $\mathrm{ZnCl}(2)$ & & & & & & & & & & & & $1.12 \theta-02$ & & & & & \\
\hline$F P(g)$ & $1.58 \mathrm{e}-03$ & & & $1.58 \theta-03$ & & & $1.58 \mathrm{e}-03$ & & & & $1.58 \mathrm{e}-03$ & & $1.580-03$ & & $1.580-03$ & & \\
\hline$F P(s)$ & $8.820-03$ & & & & & & & & & & & & & & & $6.0 e-05$ & \\
\hline$F P-C /(g)$ & & & & $8.82 \mathrm{e}-03$ & & & & & & & & & & & & & \\
\hline$F P-C /(s)$ & & & & & & & & $8.82 \theta-03$ & & & & LLW-CI & & & & & $8.82 \mathrm{e}-03$ \\
\hline$T R U(s)$ & $7.360-05$ & & & & & & & & & & & & & & & & \\
\hline TRU-CI/g) & & & & $7.36 e-05$ & & & & $7.36 \mathrm{e}-05$ & & & & & & & & & \\
\hline TRU-Cl(s) & & & & & & & & & & & & $<100 \mathrm{nCi} / \mathrm{g}$ & & & & & $7.36 e-05$ \\
\hline Remeining (OB.C.Li) & $2.140-02$ & & & $2.14 e_{-02}$ & & & $2140-02$ & & & & $2.140=02$ & & $2.140-02$ & & $2.140-02$ & & \\
\hline
\end{tabular}


Chlorination: The reactor would operate within the $1500-2200 \mathrm{~K}$ temperature regime. The presence of oxygen, such as in the form of oxide film on Zircaloy, will require presence of an oxygen scavenger and a minimum temperature to prevent formation of oxychlorides of uranium. Potential oxygen scavengers include $\mathrm{CO}, \mathrm{Mo}$, and $\mathrm{Nb}$. The specific minimum temperature required to retard the formation of oxygen-containing species can be determined by thermodynamic modeling and experimental testing. Evaluations of the preferred scavenger can be made in a development program. If $\mathrm{CO}$ is used, $\mathrm{a} \mathrm{CO}_{2}$ adsorption bed in the recycle gas loop will be needed as indicated in Figure 29. (If LWR fuels are processed in the same equipment, the $\mathrm{CO}_{2}$ adsorption bed size will be based on those requirements. Carbon dioxide production for LWR fuels will be 2 moles per mole $\mathrm{UO}_{2}$, corresponding to 1.1 moles per mole total fuel components.)

To initiate the reaction, the heat source if needed, can be provided with a plasma torch or electrical heater. Once the chlorination reaction is initiated, the heat of reaction should sustain the desired temperature. The kilomoles $(\mathrm{kmol})$ of chlorides formed $/ 100 \mathrm{~kg}$ fuel are given in stream $1 \mathrm{~d}$ of the material balance. About $93 \mathrm{MOL} \%$ of the product chlorides is $\mathrm{ZrCl}_{4}$, with chlorides of $\mathrm{Sn}, \mathrm{Cr}, \mathrm{Fe}, \mathrm{Ni}$, and $\mathrm{U}$ each contributing 0.4 to $2 \%$ to the product stream. The product flow of fuel element chlorides is about $6.3 \%$ of the total gas flow. The larger and constant flowrate of $\mathrm{Ar}$ and $\mathrm{Cl}_{2}$ serves to maintain approximately constant volumetric flowrates through the downstream scrubber and condensers when fluctuations in the product flowrate occurs. The Ar also serves as a heat sink in the chlorinator to maintain the reactor off gas in the desired temperature range.

Rate of reaction can be controlled, in part, by splitting the recycled $\mathrm{Ar} / \mathrm{Cl}_{2}$ gas stream and feeding the appropriate amount of $\mathrm{Cl}_{2}$ to the spent fuel via Stream $1 \mathrm{~b}$. The excess $\mathrm{Cl}_{2}$ in Stream 1c will serve to complete chlorination of gas-phase species not fully chlorinated by Stream $1 \mathrm{~b}$. Stream $1 \mathrm{e}$ will replace $\mathrm{Cl}_{2}$ consumed in the chlorination reactor. All gas-phase products except Xe and $\mathrm{Kr}$ will be continuously removed downstream. Batch cryogenic processing will occasionally be required to remove the $\mathrm{Xe}$ and $\mathrm{Kr}$ from the carrier gas.

To control the temperature in the chlorinator, conservative calculations assuming adiabatic reaction indicate that a mole ratio of approximately $13 \mathrm{Ar}: 2.9 \mathrm{Cl}_{2}: 1 \mathrm{Zr}$ is required to limit the temperature to less that $2400 \mathrm{~K}$. Heat losses will result in a somewhat lower temperature. The temperature can be controlled by a combination of Ar dilution, blending the dilution stream 1c for exiting product gases close to the reaction (fuel) zone, and cooling the reactor walls. No heat can be applied to the incoming gas, $1 \mathrm{~b}$, after reaction initiation.

For the present flowsheet calculations, it is assumed that, with wall cooling, a $10 \mathrm{Ar}: 2.9 \mathrm{Cl}_{2}: 1.0$ $\mathrm{Zr}$ mole ratio will be adequate to limit the reaction temperature to ca. $2400 \mathrm{~K}$ and that wall temperatures can be maintained at less that $2000 \mathrm{~K}$. To bring the exiting product gas stream down to $1800 \mathrm{~K}$ will require that the volume flowrate of Stream $1 \mathrm{c}$ be 44.5 percent of the product stream flowrate. Additional $\mathrm{Cl}_{2}$ will need to be added at $1 \mathrm{f}$ to provide sufficient excess $\mathrm{Cl}_{2}$; this will provide additional cooling. Therefore, less Stream $1 \mathrm{c}$ will be needed for cooling. A 
complete balance of streams to result in controlled product Stream 1d temperature and adequate excess $\mathrm{Cl}_{2}$ results in a split between $1 \mathrm{c}$ and $1 \mathrm{~b}$ of $1: 4$ and addition at $1 \mathrm{f}$ of $2.06 \mathrm{kmol} \mathrm{Cl}_{2} / 100 \mathrm{~kg}$ fuel. This will cool the $2400 \mathrm{~K}$ product gas stream to $1750 \mathrm{~K}$.

Additional makeup $\mathrm{Cl}_{2}$ is added to the recycled gas at point le to replace that which was consumed by reaction that is not provided at Stream $1 \mathrm{f}$.

Major developmental concerns include: materials of construction for both high-temperature operation and corrosion resistance, determination of reaction rates and chloride species distribution, avoidance of cold zones where undesirable condensates would collect, and methodologies for feeding and heating the fuel element in the reactor. A promising material is a high kinetic energy, flame spray-coated, $\mathrm{ZrO}_{2}$ onto a substrate. This process, being developed at Oregon Graduate Institute of Science and Technology, produces a high-density, high-integrity bonded material, and $\mathrm{ZrO}_{2}$ is non-reactive to $\mathrm{Cl}_{2}$. Additives can yield coefficients of thermal expansion similar to that of the substrate. Graphite has been used as vessel material for chlorination of zircon sand in the production of zirconium, and may be applicable for this process.

Molten Salt Scrubber: The molten salt scrubber is designed to remove FP- and TRU chlorides to a level which makes all downstream condenser products non-HLW and non-TRU wastes; it also serves as a heat sink to cool the high-temperature gas from about $1800 \mathrm{~K}$ to $673 \mathrm{~K}$. The molten salt is recycled to minimize the amount of HLW and TRU waste generated. A countercurrent scrubber is indicated in Figure 29; however, alternative designs can be evaluated. For example, a simple bubbler in a cooled vessel might suffice.

Zinc chloride was selected for the scrubber medium because of its low melting point and favorable vapor pressure. These permit its use in scrubbing the chlorinator off gas at a low temperature, $673 \mathrm{~K}$, while being sufficiently volatile at $1000 \mathrm{~K}$ to allow evaporative separation from the radioactive waste chlorides, for subsequent recycle. The solubility limit of $\mathrm{ZrCl}_{4}$ in $\mathrm{ZnCl}_{2}$ is about 50 mole percent; excess $\mathrm{ZrCl}_{4}$ will pass through. The addition of $\mathrm{ZrCl}_{4}$ results in a mixture with improved viscosity properties, as compared to pure $\mathrm{ZnCl}_{2}$, and it can be recycled with the molten salt without further complicating the flowsheet.

In Table 27 a comparison is displayed between equilibrium vapor pressures of pure condensed phase components at $673 \mathrm{~K}$ and partial pressures of some of the chlorides generated in the chlorination reactor (based on processing rate and total gas flow). The fractions of chlorides that would pass through the molten salt scrubber are calculated by ratioing the saturated vapor pressures to the partial pressures, and the results are displayed. 
Table 27. Fraction of Chlorides Which Pass Through the Scrubber

\begin{tabular}{|l|l|r|r||}
\hline & $\begin{array}{l}\text { Processing Rate } \\
\text { Partial Pressure in } \\
\text { Chlorination Reactor } \\
\text { (torr) }\end{array}$ & $\begin{array}{l}\text { Vapor Pressure @ } \\
\text { 673 K (torr) }\end{array}$ & $\begin{array}{l}\text { Vapor Fraction } \\
\text { Passing Through } \\
673 \text { K Scrubber }\end{array}$ \\
\hline $\mathrm{ZrCl}_{4}$ & 44 & 5510 & 1 \\
\hline $\mathrm{CrCl}_{3}$ & 0.30 & $4.4 \mathrm{E}-6$ & $1.5 \mathrm{E}-5$ \\
\hline $\mathrm{NiCl}_{2}$ & 0.17 & $7.1 \mathrm{E}-9$ & $4.2 \mathrm{E}-8$ \\
\hline $\mathrm{CsCl}$ & 0.049 & $2.6 \mathrm{E}-5$ & $4.2 \mathrm{E}-4$ \\
\hline $\mathrm{SrCl}_{2}$ & 0.19 & $4.1 \mathrm{E}-15$ & $2.2 . \mathrm{E}-13$ \\
\hline $\mathrm{PuCl}_{3}$ & $3.2 \mathrm{E}-3$ & $3.1 \mathrm{E}-10$ & $9.7 \mathrm{E}-8$ \\
\hline $\mathrm{NpCl}_{4}$ & $1.7 \mathrm{E}-3$ & $6.1 \mathrm{E}-3$ & 1 \\
\hline $\mathrm{AmCl}_{3}$ & $1.3 \mathrm{E}-5$ & $\sim 3.1 \mathrm{E}-10$ & $\sim 2.4 \mathrm{E}-5$ \\
\hline
\end{tabular}

This table serves to illustrate the point that the major inert chloride $\left(\mathrm{ZrCl}_{4}\right)$ should pass through the $\mathrm{ZnCl}_{2}$ scrubber (other than that absorbed to form a binary mixture) whereas the $\mathrm{Cr}$ - and the $\mathrm{Ni}$ chlorides will be removed. As will be shown in the discussion of condensation, the fractions of FP- and TRU chlorides (including $\mathrm{NpCl}_{4}$ ) that pass through the scrubber are sufficiently small to render the downstream products as non-HLW and non-TRU wastes. The fractions of FP- and TRU chlorides passing through the scrubber are most likely conservative estimates because solubility effects of the chlorides in the salt, which may lower equilibrium vapor pressures of dissolved species by orders of magnitude, are not taken into account.

Once the molten salt is saturated, it may be recovered for recycle. $\mathrm{ZnCl}_{2}$ was selected for the scrubber because its melting temperature $(556 \mathrm{~K})$ is well below $673 \mathrm{~K}$, and its vapor pressure ( 0.49 torr) at $673 \mathrm{~K}$ is low enough to minimize transport to the $\mathrm{ZrCl}_{4}$ condenser, and its boiling temperature $(1005 \mathrm{~K})$ is low enough to allow separation from most of the FP and TRU chlorides for recycle. Any $\mathrm{ZrCl}_{4}, \mathrm{UCl}_{6}, \mathrm{FeCl}_{3}$, and other low-boiling point chlorides that may have dissolved in $\mathrm{ZnCl}_{2}$ during scrubbing will be distilled off and recycled in the gas phase (Stream $2 \mathrm{c}$ ) to the molten salt scrubber. Very small quantities of the more volatile (at $1000 \mathrm{~K}$ ) FP chlorides $\left(\mathrm{CsCl}\right.$ and $\left.\mathrm{RuCl}_{3}\right)$ can be recycled to the scrubber. However, these constituents will achieve steady-state levels such that no further net absorption of $\mathrm{ZrCl}_{4}, \mathrm{UCl}_{6}$, etc. will occur during scrubbing, and that no further buildup of $\mathrm{Cs}$ or $\mathrm{Ru}$ in the scrubber will occur due to vapor phase transport during regeneration and recycle of the molten salt.

A loading of about $10 \mathrm{wt} \%$ of Cr-, Ni-, FP-, and TRU chlorides was chosen for the molten salt scrubber design before recycle. The scrubber was sized for 30 days of continuous operation 
( 4.5 metric tons of salt with a volume of $1600 \mathrm{~L}$ ). A counter-current scrubber is suggested in the process flowsheet to optimize gas-liquid contact and to expedite gas flow through the melt. However, if high-temperature pump technology is not sufficiently developed, gas sparging through a static scrubber is an attractive alternative due to its design simplicity.

Transfer of the spent salt to the molten salt regeneration vessel via Stream $2 \mathrm{~b}$ can be done by melting a freeze plug and gravity flow. Transport of the regenerated molten salt through Stream $2 \mathrm{c}$ will be by vapor phase and condensation in the scrubber vessel. Fresh $\mathrm{ZnCl}_{2}$ will be added via Stream $2 \mathrm{~d}$ to replace that lost by vapor transport to the $\mathrm{ZrCl}_{4}$ condenser during scrubbing.

Major developmental concerns include materials of construction, pumps and valves that will operate in the high temperature and corrosive environment, verification of FP and TRU removal efficiencies, verification of FP and TRU separation during regeneration, and determination of steady-state levels of radiologically inert materials and FPs in the regenerated/recycled salt scrubber.

Fractional Condensation: The first condenser will be operated at about $437 \mathrm{~K}$ and recover primarily $\mathrm{ZrCl}_{4}$ along with $\mathrm{FeCl}_{3}$ and volatilized $\mathrm{ZnCl}_{2}$. Based on feed rate and equilibrium vapor pressure ratios, $99.4 \%$ and $75 \%$ of the $\mathrm{ZrCl}_{4}$ and $\mathrm{FeCl}_{3}$ will be recovered, respectively, with the remainder being recovered in the downstream $\mathrm{UCl}_{6}$ condenser. The mole ratio of volatilized $\mathrm{ZnCl}_{2}$ to $\mathrm{ZrCl}_{4}$ will be about 0.01 . The partial pressure of $\mathrm{UCl}_{6}$ resulting from the feed concentration of uranium is calculated to be well below its saturation vapor pressure at 473 $\mathrm{K}$, which should prevent it from co-condensing.

It is of crucial importance that the amount of FP- and TRU chlorides passing through the molten salt scrubber not cause the condenser product to be classified as either greater than Class $\mathrm{C}$ (GTCC) waste or as TRU waste. Table 28 compares the mass ratios of HLW- and TRU

Table 28. Mass Ratios of FP-Cl and TRU-Cl to $\mathrm{ZrCl}_{4}$ in the Condenser

\begin{tabular}{|l|r|r|r|r||}
\hline Species & $\begin{array}{l}\text { Mole Fraction in } \\
\text { Chlorination } \\
\text { Reactor Off-Gas }\end{array}$ & $\begin{array}{l}\text { Fraction Passing } \\
\text { Through Scrubber }\end{array}$ & $\begin{array}{l}\text { Molecular } \\
\text { Weight }\end{array}$ & $\begin{array}{l}\text { Mass Ratio } \\
\text { g/g ZrCl }\end{array}$ \\
\hline $\mathrm{ZrCl}_{4}$ & 0.9061 & 1 & 233 & - \\
\hline $\mathrm{CsCl}$ & $1.0 \mathrm{E}-3$ & $5.3 \mathrm{E}-4$ & 172 & $4.4 \mathrm{E}-7$ \\
\hline $\mathrm{SrCl}_{2}$ & $4.0 \mathrm{E}-4$ & $2.2 \mathrm{E}-13$ & 161 & $6.8 \mathrm{E}-17$ \\
\hline $\mathrm{PuCl}_{3}$ & $3.0 \mathrm{E}-5$ & $9.7 \mathrm{E}-8$ & 345 & $4.7 \mathrm{E}-12$ \\
\hline $\mathrm{NpCl}_{4}$ & $3.7 \mathrm{E}-5$ & 1 & 379 & $6.6 \mathrm{E}-5$ \\
\hline $\mathrm{AmCl}_{3}$ & $2.7 \mathrm{E}-7$ & $2.4 \mathrm{E}-5$ & 347 & $1.1 . \mathrm{E}-11$ \\
\hline
\end{tabular}


chlorides to the major inert chloride $\left(\mathrm{ZrCl}_{4}\right)$ that will collect in the $\mathrm{ZrCl}_{4}$ condenser based on the fraction of the chlorides passing through the molten salt scrubber given in Table 27.

To compare the mass loading ratios of $\mathrm{CsCl}$ and $\mathrm{SrCl}_{2}$ to the upper limits for $\mathrm{LLW}$, the units must be in $\mathrm{Ci} / \mathrm{m}^{3}$ (for example, for Cs- 137 and Sr-90 the limits are 4600 and $7000 \mathrm{Ci} / \mathrm{m}^{3}$, respectively). Using a density of $2.8 \mathrm{E}+06 \mathrm{~g} \mathrm{ZrCl}_{4} / \mathrm{m}^{3}$ and specific activities of 82.6 and $141 \mathrm{Ci} / \mathrm{g}$ yields loadings of 101 and $2.7 \mathrm{E}-08 \mathrm{Ci} / \mathrm{m}^{3}$ for Cs- 137 and $\mathrm{Sr}-90$, respectively. Both of these loadings are well below the limits.

To compare the mass loading ratios of the TRU $\mathrm{Cl}$ to the upper limit of non-TRU waste (i.e., 100 $\mathrm{nCi} / \mathrm{g}$ ), the mass loading ratios are multiplied by $10^{9} \mathrm{nCi} / \mathrm{Ci}$ and the specific activities of the isotopic distributions (in the spent fuel) of $\mathrm{Pu}, \mathrm{Np}$, and $\mathrm{Am}$, which are 2.28, 7.02E-4, and 3.42 $\mathrm{Ci} / \mathrm{g}$, respectively. This yields activity/mass loadings of $0.011,46,0.036 \mathrm{nCi} / \mathrm{g}$ for $\mathrm{Pu}, \mathrm{Np}$, and $\mathrm{Am}$, respectively. The only TRU which approaches the upper limit of non-TRU waste is $\mathrm{Np}$. This loading (along with all the others) may be highly conservative when solubility effects of $\mathrm{NpCl}_{4}$ in the $\mathrm{ZnCl}_{2}$ molten salt are taken into account or if a fluidized bed of alumina is used as an inert condensing medium in the condenser.

Major development concerns include determining the best methods for maximizing efficiency of recovery in, and removal from, the condenser of $\mathrm{ZrCl}_{4}$ and loadings of co-condensed $\mathrm{FP}, \mathrm{TRU}$, $\mathrm{U}$, and Fe.

The second condenser will operate at about $300 \mathrm{~K}$ to remove $\mathrm{UCl}_{6}$ from gas stream $3 \mathrm{a}$ at 99.8 efficiency. Residual amounts of $\mathrm{FeCl}_{3}$ and $\mathrm{ZrCl}_{4}$ passing through the upstream $\mathrm{ZrCl}_{4}$ condenser will also co-condense. The composition of the condensate would consist of about 51,27, and 22 mole percent of $\mathrm{U}-, \mathrm{Zr}$-, and $\mathrm{Fe}$ chlorides, respectively. FP- and TRU chlorides levels will be several orders of magnitude below the limits of GTCC and TRU wastes.

Development concerns include determining the best methods for maximizing efficiency of recovery and the removal of condensates in the condenser.

The third condenser will be operated at a temperature slightly below that of the $\mathrm{UCl}_{6}$ condenser for the purpose of removing $\mathrm{SnCl}_{4}$ and $\mathrm{I}_{2}$. Both of these gases will be initially below their saturation vapor pressures, but will begin to build up to condensable levels within a day in the recycled $\mathrm{Ar} / \mathrm{Cl}_{2}$ gas Stream 5a. Without the slightly cooler condenser downstream of the $\mathrm{UCl}_{6}$ condenser, these two chlorides would co-condense with the $\mathrm{UCl}_{6}$ product. The iodine will condense as a solid but the $\mathrm{SnCl}_{4}$, which melts at $240 \mathrm{~K}$, will condense as a liquid.

Molten Salt Regeneration/Fluorination: At $1000 \mathrm{~K}$, the temperature selected for vaporizing and recycling the molten salt, the Ni- and $\mathrm{Cr}$ chlorides, as well as most of the FP- and TRU chlorides, are below their melting points. These metals represent about $2.6 \%$ of the mass of the 
design basis fuel element. To make them compatible with a glass waste form, conversion to the fluorides is necessary and could possibly be achieved by introducing $F_{2}(\mathrm{~g})$, at about $1000 \mathrm{~K}$ and an appropriate pressure, and maintaining these conditions until conversion was complete. An alternative method is to add boric acid to the chloride solids and heat at about $1273 \mathrm{~K}$ to form the oxides that may be incorporated into a glass.

The metal fluorides are generally higher melting and boiling point compounds than the corresponding chlorides; subsequently, an extremely high temperature will be required to transport all of the fluorides, as either a melt or gas, from the vessel. For example, $\mathrm{SrF}_{2}$ melts at $1746 \mathrm{~K}$ and boils at $2762 \mathrm{~K}$. The same problem exists for the oxides. An alternative to removing FP and TRU from the vessel will be to accumulate sufficient wastes in the vessel from several campaigns, convert them to fluorides or oxides, add molten glass to the vessel, and heat the mixture for the time required for dissolution and blending of the wastes into the glass. In this manner the vessel will serve three unit operation functions: recycling of the molten salt, fluorination or oxidation of wastes, and vitrification of the waste.

If transfer of the Ni-, Cr-, FP-, and TRU chlorides from the vessel were determined to be the preferable option, the use of aqueous methods would probably be necessary to dissolve the chlorides. This will also place them in a state amenable for separating the TRUs from the waste using the TRUEX process.

Separation of Transuranics from Fission Products: An alternative treatment prior to conversion of the residual radionuclides to glass may be removal of the transuranics. A TRUEX process is one possible approach to accomplishing the separation. The salts would be dissolved

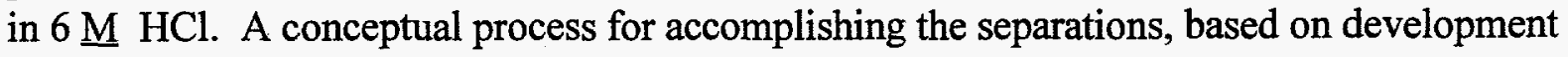
work at Argonne National Laboratory, is depicted in Figure 30. The product and raffinate streams could be evaporated to recover $\mathrm{HCl}$ for recycle and the residues converted to glass as discussed above. 


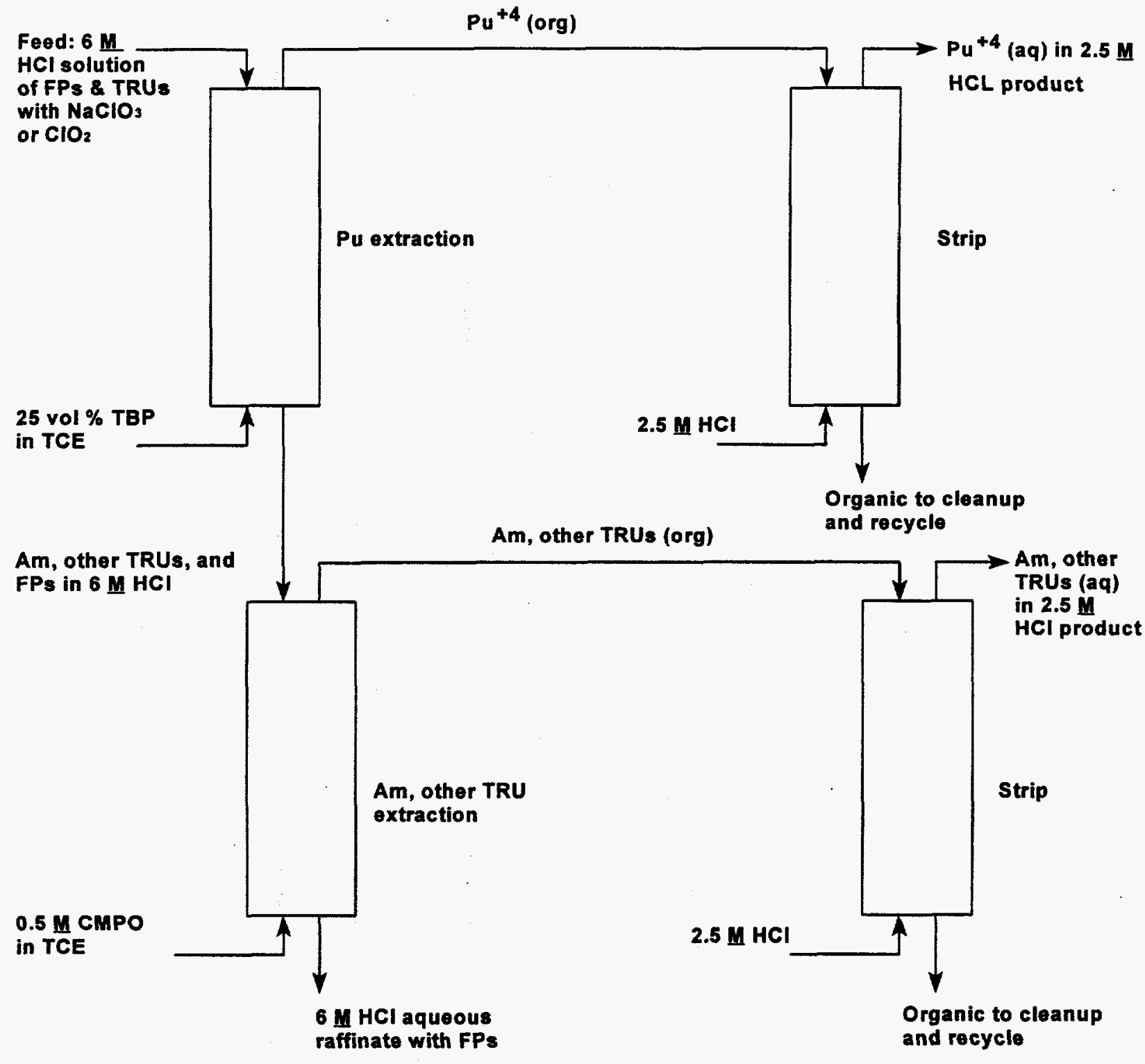

Figure 30. TRUEX Separation of TRUs from Fission Products 
Waste Forms and Quantities from Zircaloy Fuel

The amounts of the various wastes produced by the chloride volatility process are given in Streams $3 b, 4 b, 5 b$, and $6 a$ of the process flowsheet. The wastes are expressed in kmol of fuel component chlorides $/ 100 \mathrm{~kg}$ of fuel processed. Final volume and weights of the waste streams will depend on amounts of components added for fixation. Cement is the likely additive for $\mathrm{ZrCl}_{4}, \mathrm{FeCl}_{3}$, and $\mathrm{SnCl}_{4}$ components and glass for the $\mathrm{FP}^{-}, \mathrm{TRU}-\mathrm{Ni}^{-}$, and $\mathrm{Cr}$ chloride components.

HLW Form -- For the FP/TRU, Ni, and Cr wastes as fluorides, a mass loading of $25 \mathrm{wt} \%$ in borosilicate glass is assumed. The fluoride generation rate is $2500 \mathrm{~g} / 100 \mathrm{~kg}$ of fuel, which will yield $10,000 \mathrm{~g}$ of glass waste $/ 100 \mathrm{~kg}$ of fuel. Assuming a glass density of $2.7 \mathrm{~g} / \mathrm{cm}^{3}$ will result in a yield of $3.7 \mathrm{~L}$ of glass FP/TRU waste per $100 \mathrm{~kg}$ of fuel processed or $37 \mathrm{~L}$ per ton for those fuels that contain stainless steel. For the approximately 70 percent of Zircaloy fuels that do not contain stainless steel, the quantity will be $2.2 \mathrm{~L}$ glass per $100 \mathrm{~kg}$ fuel $(22 \mathrm{~L} / \mathrm{ton})$; the net average quantity would be $26 \mathrm{~L} /$ ton.

LLW Form from the $\mathrm{ZrCl}_{4}$ Condenser: No additive to the $\mathrm{ZrCl}_{4} / \mathrm{FeCl}_{3}$ waste will be required to meet the class $\mathrm{C}$ waste and the waste will most likely meet the class $\mathrm{B}$ waste specifications. The main requirement will be that the waste form or the container must maintain its gross physical properties and identity for 300 years.

The density of $\mathrm{ZrCl} 4$ is $2.8 \mathrm{~kg} / \mathrm{L}$ and the production rate of the $\mathrm{ZrCl} 4 / \mathrm{FeCl} 3$ waste is about 1.02 $\mathrm{kmol}$ or $237 \mathrm{~kg} / 100 \mathrm{~kg}$ of fuel processed, resulting in a waste volume of $85 \mathrm{~L} / 100 \mathrm{~kg}$ fuel. If the chlorides were fixed in a 50/50 volumetric mix of wastes to concrete, the final waste form will be $170 \mathrm{~L}$. A standard waste drum for LLW burial has a volume of 55 gallons $(210 \mathrm{~L})$; therefore, based on these assumptions, about one waste drum of LLW from the $\mathrm{ZrCl}_{4}$ condenser (stream 3b) per $100 \mathrm{~kg}$ of fuel will be generated; fuels without stainless steel will yield nearly the same volumes.

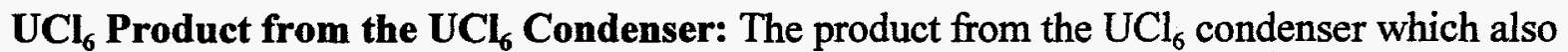
contains chlorides of $\mathrm{Z}$ and $\mathrm{Fe}$ (mole ratios of $0.41 \mathrm{U}, 0.32 \mathrm{Zr}$, and $0.27 \mathrm{Fe}$ ), contains the HEU and will be subjected to safeguards and criticality control considerations. The above product distribution equates to a total of $2.7 \mathrm{E}-04 \mathrm{kmol}$ or $8.2 \mathrm{~kg}$ chlorides $/ 100 \mathrm{~kg}$ fuel processed. Final disposition of HEU remains unresolved in U.S. policy; therefore, no waste form is suggested for this product.

LLW Product from the $\mathrm{SnCl}_{4}$ Condenser: The $\mathrm{SnCl}_{4}$ condenser will recover $1.14 \mathrm{E}-02 \mathrm{kmol}$ $\left(3 \mathrm{~kg}\right.$ ) of $\mathrm{SnCl}_{4}$ per $100 \mathrm{~kg}$ of spent fuel; about $4 \mathrm{~g}$ of HEU and $7.7 \mathrm{~g}$ of I-129 will also be recovered. The LLW limit for I- $129 \mathrm{is} 0.08 \mathrm{Ci} / \mathrm{m}^{3}$ of waste. Using a liquid $\mathrm{SnCl}_{4}$ density of 2.2 $\mathrm{g} / \mathrm{cm}^{3}$ and a specific activity of $1.6 \mathrm{E}-04 \mathrm{Ci} / \mathrm{g}$ for I-129 yields an iodine loading of $0.9 \mathrm{Ci}$ I-129 per $\mathrm{m}^{3}$ of $\mathrm{SnCl}_{4}$. This is a factor of 11.3 too high to qualify as LLW and will require a dilution in 
cement or another matrix. Using the dilution factor of 11.3 yields $15.4 \mathrm{~L}$ of $\mathrm{SnCl}_{4}$ in cement per $100 \mathrm{~kg}$ of spent fuel processed.

\section{Specific Operations for Aluminum Fuels}

The aluminum fuel flow sheet is shown in Figure 31. This process is based on that developed for naval fuel, with modifications to accommodate the differences between the chlorination chemistries of these two fuel types. The aluminum fuel flowsheet implements the same chlorination reactor, molten salt scrubber, and molten salt regenerator. The differences, as compared to the naval fuel process, are the fractional condenser unit processes. For the aluminum fuel process, $\mathrm{AlCl}_{3}$ and $\mathrm{UCl}_{6}$ co-condense in the first condenser, which is operated at $300 \mathrm{~K}$. The second condenser is bypassed, and $\mathrm{SiCl}_{4}$ and $\mathrm{I}_{2}$ co-condense in the third condenser after each has built up to its saturation point in the process stream. The amount of $\mathrm{Cl}_{2}$ added to the process stream during recycling is roughly $75 \%$ of that added during naval fuel processing because the stoichiometry of the aluminum-chlorine reaction is $1 \mathrm{Al}$ to $3 \mathrm{Cl}$.

Chlorination: The chlorination reactor will operate in the $1500-2000 \mathrm{~K}$ temperature range during the processing of aluminum-clad fuels. Initiation of the chlorination reaction will be required; the heat source can be a plasma torch, electrical resistance heater or an induction furnace. Even after the reaction has been initiated, it may be necessary to continue to heat the gas, fuel, or both. The standard enthalpy of formation of $\mathrm{AlCl}_{3}(\mathrm{~g})$ at $2000 \mathrm{~K},-144.48 \mathrm{kcal} / \mathrm{mole}$, is considerably less negative than that for $\mathrm{ZrCl}_{4}$ at the same temperature (at which it is likely that the Zircaloy chlorination temperature may be sustained by the heat released during the reaction), $-207.99 \mathrm{kcal} / \mathrm{mole}$. The calculated adiabatic temperature for $\mathrm{Cl}_{2}$ reaction with aluminum fuel for composition given in Table 2 (assuming 75 percent action of the $\mathrm{Cl}_{2}$ ) is $5316 \mathrm{~K}$. However, when the carrier gas $\mathrm{Ar}$ is added at a $4: 1$ mole ratio to $\mathrm{Cl}_{2}$, it is $1986 \mathrm{~K}$. The actual temperature will be less because of heat losses. It may be possible, by adjusting the Ar amount, to maintain a desirable temperature. Further evaluation is necessary to determine whether auxiliary heating will have to be provided.

The oxygen content of these fuels is small, with the oxygen present as an $\mathrm{Al}_{2} \mathrm{O}_{3}$ polymorph on the surface of the fuel. The presence of the surface oxide will require that an oxygen scavenger be used during chlorination as alumina cannot be chlorinated under these conditions. Possible scavengers include $\mathrm{CO}, \mathrm{Mo}$, and $\mathrm{Nb}$; the behavior of these and others could be investigated during development work.

The flowsheet for this fuel is based on the same feedrate as for the Zircaloy-clad fuels, 0.217 kilomoles/hour. The product chlorides will account for only $6.4 \%$ of the total gas flow leaving the chlorination reactor, with argon and chlorine making up the remainder. Of the product gas, $\mathrm{AlCl}_{3}$ accounts for about $97 \%, \mathrm{UCl}_{6}$ about $1 \%$, and $\mathrm{SiCl}_{4}$ about $0.4 \%$, with remainder being FP and TRU chlorides (about 1\%). 


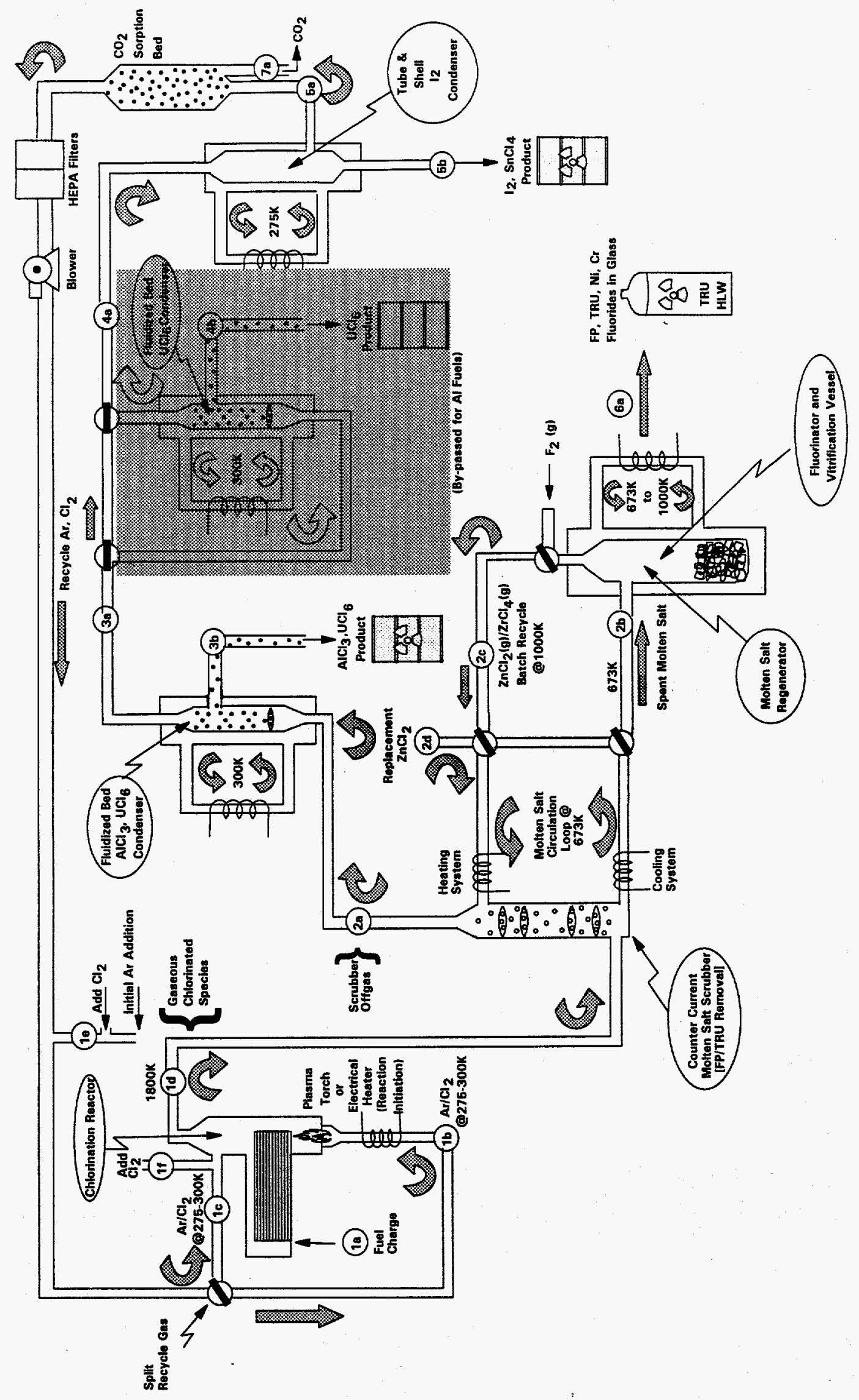

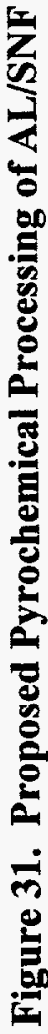


Molten Salt Scrubber: The molten salt scrubber unit operation performs two functions: temperature control and chemical separation. The gas stream enters the scrubber at a nominal temperature of $1800 \mathrm{~K}$ and departs at $673 \mathrm{~K}$. The separation of FPs and TRUs is accomplished in a dual fashion. The molten salt acts as a solvent to dissolve these chemical species, and because of the scrubber temperature, which is below the condensation and normal freezing point of most of these species, it also acts as a condenser that freezes these phases out of the gas stream.

Zinc chloride is the scrubber medium of choice for this unit operation because its low volatility at the operating temperature, 0.5 torr at $673 \mathrm{~K}$, coupled with its low normal boiling point, $1005 \mathrm{~K}$, result in low entrainment of molten salt in the process stream and recyclability by fractional distillation at a reasonable temperature. The actual recovery process was described during the discussion of Zircaloy-clad fuel processing.

Loadings of inerts (non-radioactive fuel constituents) in the $\mathrm{ZnCl}_{2}$ should be minimal. In the flowsheet calculations it is assumed that freezing of the FP- and TRU chlorides accounts for the separation of these species from the product stream; no acknowledgment is granted for the solubility of the FP- and TRU chlorides in the molten salt. While $\mathrm{AlCl}_{3}$ forms stable binary phases with $\mathrm{ZnCl}_{2}$, at temperatures below $673 \mathrm{~K}$, the liquid phase decomposes to produce $\mathrm{ZnCl}_{2}(\mathrm{l})$ and $\mathrm{AlCl}_{3}(\mathrm{~g})$ above $673 \mathrm{~K}$. As described earlier, $\mathrm{UCl}_{6}$ is soluble in $\mathrm{ZnCl}_{2}$, but once the solution is saturated the balance of the $\mathrm{UCl}_{6}$ will pass through the solution. The solubility of $\mathrm{SiCl}_{4}$ in $\mathrm{ZnCl}_{2}$ is not known, but $\mathrm{SiCl}_{4}$ is very volatile, with a normal boiling point of $331 \mathrm{~K}$; consequently, it is unlikely that it is very soluble in $\mathrm{ZnCl}_{2}$.

Table 29 is a tabulation of process stream partial pressures at $673 \mathrm{~K}$ of the most important chemical species in the fuel, the vapor pressures of the species over the pure condensed component at that temperature, and the fraction of each species that is expected to pass through

Table 29. Fraction of Chlorides Which Pass Through the Scrubber

\begin{tabular}{|l|r|r|l||}
\hline \hline & $\begin{array}{l}\text { Processing Rate } \\
\text { Partial Pressure in } \\
\text { Chlorination Reactor } \\
\text { (torr) }\end{array}$ & $\begin{array}{l}\text { Vapor Pressure @ } \\
\text { 673 K (torr) }\end{array}$ & $\begin{array}{l}\text { Vapor Fraction } \\
\text { Passing Through } \\
\text { Scrubber @ 673 K }\end{array}$ \\
\hline $\mathrm{AlCl}_{3}$ & 48 & $>760$ & 1 \\
\hline $\mathrm{SiCl}_{4}$ & 0.20 & $>760$ & 1 \\
\hline $\mathrm{UCl} l_{6}$ & 0.56 & $>760$ & 1 \\
\hline $\mathrm{CsCl}$ & $3.1 \mathrm{E}-3$ & $2.6 \mathrm{E}-5$ & $8.4 \mathrm{E}-3$ \\
\hline $\mathrm{SrCl}_{2}$ & $1.7 \mathrm{E}-3$ & $4.1 \mathrm{E}-15$ & $2.4 \mathrm{E}-12$ \\
\hline $\mathrm{PuCl}_{3}$ & $1.7 \mathrm{E}-3$ & $3.1 \mathrm{E}-10$ & $1.8 \mathrm{E}-7$ \\
\hline
\end{tabular}


the scrubber, based on the vapor pressures. The fractions passing through for $\mathrm{AlCl}_{3}, \mathrm{SiCl}_{4}$, and $\mathrm{UCl}_{6}$ are essentially $100 \%$, while very small fractions of $\mathrm{CsCl}, \mathrm{SrCl}_{2}$, and $\mathrm{PuCl}_{3}$ are expected to pass through (neglecting solubility of these species in the molten salt).

Fractional Condensation: The $\mathrm{AlCl}_{3}, \mathrm{SiCl}_{4}$ and $\mathrm{UCl}_{6}$ are separated from the process gas stream by fractional condensation in cooled condensers. The first condenser operates at about $300 \mathrm{~K}$, and the $\mathrm{AlCl}_{3}$ and $\mathrm{UCl}_{6}$ are abstracted from the stream in this unit. Unlike the processing conditions for Zircaloy-clad fuels, in which the $\mathrm{ZrCl}_{4}$ and $\mathrm{UCl}_{6}$ are abstracted from the stream in separate condensers, the major constituent of the cladding is collected together with the uraniumbearing vapors in a single condenser. The vapor pressures of $\mathrm{AlCl}_{3}$ and $\mathrm{UCl}_{6}$ are quite similar, only differing by an order of magnitude at $400 \mathrm{~K}$ (the $\mathrm{UCl}_{6}$ pressure is the lower of the two), and make separation by fractional condensation essentially impossible. Separation of these two chlorides could be performed, without a great deal of difficulty, by fluorination and subsequent fractional distillation of the $\mathrm{UF}_{6}$ from the $\mathrm{AlF}_{3}$.

The gas stream leaving the $300 \mathrm{~K}$ condenser contains primarily $\mathrm{Ar}$ and $\mathrm{Cl}_{2}$, with $\mathrm{SiCl}_{4}$ being the third most abundant species. Separation of the $\mathrm{SiCl}_{4}$ and $\mathrm{I}_{2}$ species is accomplished by fractional condensation at $275 \mathrm{~K}$. Because of the low partial pressures of these two species, the $275 \mathrm{~K}$ condenser does not remove these species from the process stream until they have saturated the gas stream. The partial pressure of $\mathrm{SiCl}_{4}$ in the process stream is about 0.2 torr, while the saturation pressure at $275 \mathrm{~K}$ is about 84 torr, so the mass removed at this unit operation will not be very great (as the processing rate of $\mathrm{Si}$ is about $0.887 \mathrm{~mole} / \mathrm{hour}$ ).

As was the case for the processing of Zircaloy-clad fuels, material in the fractional condensation condensers can be removed between processing campaigns as a batch operation.

Molten Salt Regeneration/Fluorination: This unit operation and the process variables for operation are essentially identical to those for Zircaloy-clad fuel processing.

\section{Specific Operations for Stainless Steel Fuels}

The stainless steel fuel flow diagram Figure 32, is essentially identical to that for the naval fuels. The differences, as compared to the naval fuel process, are related only to the chemistry relative to the non-radioactive constituents. The amount of $\mathrm{Cl}_{2}$ added to the process stream during recycle is roughly $75 \%$ that added during naval fuel processing because the stoichiometry of the iron-chlorine reaction is $1 \mathrm{Fe}$ to $3 \mathrm{Cl}$ (assuming ferric chloride is the product). 


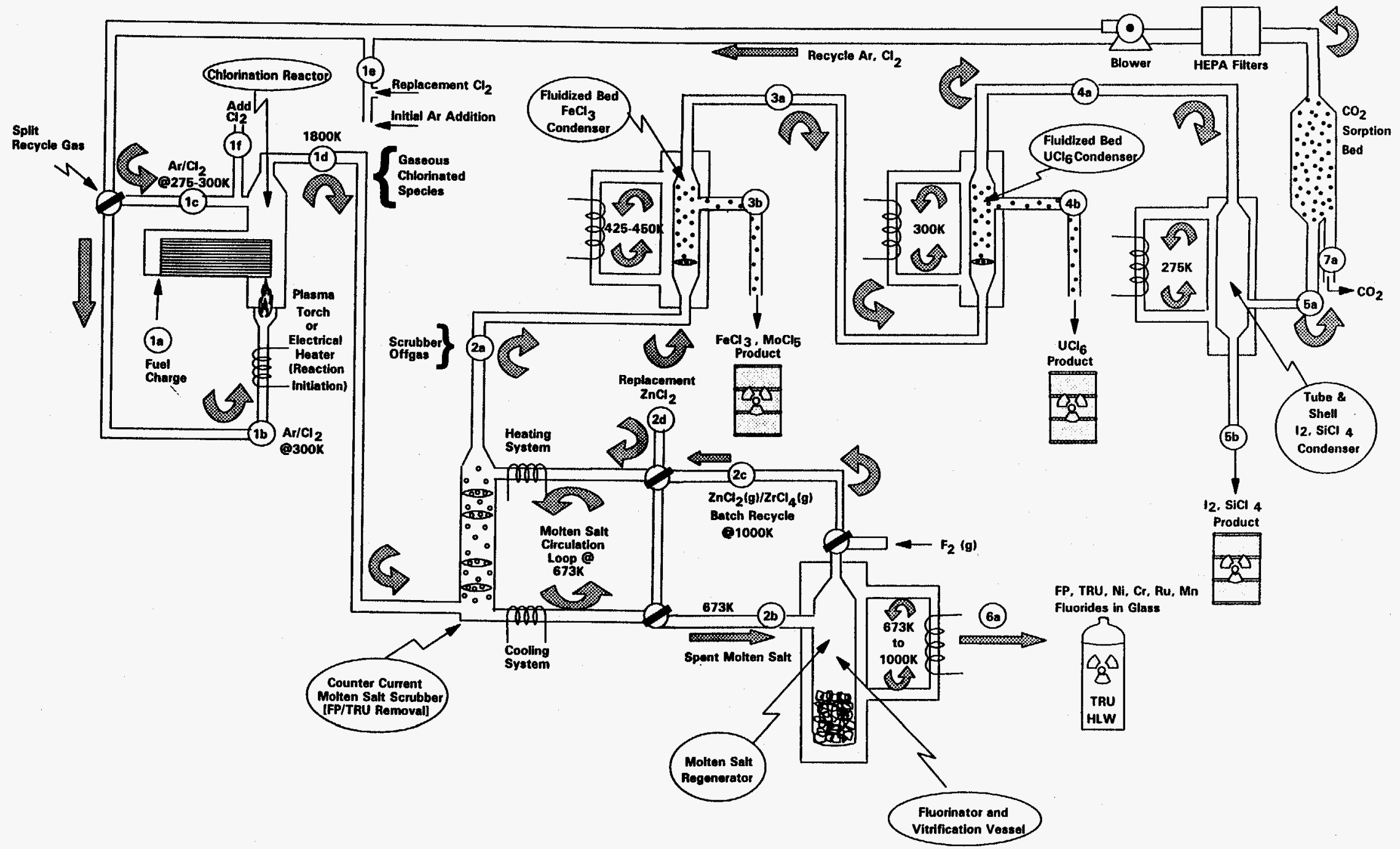

Figure 32. Proposed Pyrochemical Processing of Stainless Steel Fuels 
The stainless steel fuels include many different metal and oxide fuel meats; the fuel meat considered for this discussion is a uranium-fissium alloy ${ }^{1}$ which contains a variety of transition metals in the alloy. Of these elements, only the most abundant chlorinating metals, $\mathrm{Mo}, \mathrm{Ru}$, and $\mathrm{Si}$, will be considered.

Chlorination: The chlorination reactor would operate in the 1500-2000 K temperature range during the processing of stainless steel-clad fuels. Initiation of the chlorination reaction will be required; the heat source could be a plasma torch, electrical resistance heater or an induction furnace. Even after the reaction has been initiated, it will probably be necessary to continue to heat the gas, fuel, or both, because the standard enthalpy of formation of $\mathrm{FeCl}_{3}(\mathrm{~g})$ (from the main fuel constituent on a mole basis) at $2000 \mathrm{~K},-69.21 \mathrm{kcal} / \mathrm{mole}$, is considerable less negative than that for $\mathrm{ZrCl}_{4}$ at the same temperature $-207.99 \mathrm{kcal} / \mathrm{mole}$, from which the Zircaloy chlorination temperature may be sustained by the heat released during the reaction. It can be concluded without a complete heat balance analysis for the stainless steel fuel that the addition of the Ar gas will result in the need to supply additional energy.

The oxygen content of these fuels is small, with the oxygen present as surface oxides of iron, nickel, and chromium (some oxide phases, as well as perovskites) of the fuel. The presence of the surface oxide may require the addition of an oxygen scavenger, which depends upon the oxides that are present. Possible scavengers include $\mathrm{CO}, \mathrm{Mo}$, and $\mathrm{Nb}$; the behavior of these and others could be investigated during development work.

The flowsheet Figure 32 for this fuel is based on the same feedrate as for the Zircaloy-clad fuels, 0.217 kilomoles/hour. The product chlorides will account for only $6.4 \%$ of the total gas flow leaving the chlorination reactor, with argon and chlorine making up the remainder. Of the product gas, $\mathrm{FeCl}_{3}$ accounts for about $41 \%, \mathrm{UCl}_{6}$ about $25 \%, \mathrm{CrCl}_{3}$ about $14 \%, \mathrm{NiCl}_{2}$ about $7 \%$, $\mathrm{MoCl}_{5}$ about $2 \%, \mathrm{RuCl}_{\mathrm{x}}$ (where $\mathrm{x}=3$ or 4 ), $\mathrm{SiCl}_{4}$ about $1 \%$ each, with remainder being $\mathrm{FP}$ and TRU chlorides (about 8\%).

Molten Salt Scrubber: As is the case for the naval and aluminum fuel flowsheets, the molten salt scrubber unit operation performs two functions: temperature control and chemical separation. The gas stream enters the scrubber at a nominal temperature of $1800 \mathrm{~K}$, and departs at $673 \mathrm{~K}$. The separation of FPs and TRUs is accomplished in a dual fashion. The molten salt acts as a solvent to dissolve these chemical materials, and because of the scrubber temperature, which is below the condensation and normal freezing point of most of these materials, it also acts as a condenser that freezes these phases out of the gas stream.

Zinc chloride is the scrubber medium of choice for this unit operation because its low volatility at the operating temperature, 0.5 torr at $673 \mathrm{~K}$, coupled with its low normal boiling point,

${ }^{1}$ Fissium is an alloy of 48.9 weight percent (w/o) Mo, $38.8 \mathrm{w} / \mathrm{o} \mathrm{Ru}, 5.4 \mathrm{w} / \mathrm{o} \mathrm{Rh}, 1.7 \mathrm{w} / \mathrm{o} \mathrm{Pd}$, $1.0 \mathrm{w} / \mathrm{o} \mathrm{Si}$ and $0.3 \mathrm{w} / \mathrm{o} \mathrm{Nb}$. 
$1005 \mathrm{~K}$. These properties result in low entrainment of molten salt in the process stream and recyclability by fractional distillation at a reasonable temperature. The actual recovery process was described during the discussion of Zircaloy-clad fuel processing.

Loadings of non-radioactive inerts in the $\mathrm{ZnCl}_{2}$ should be minimal. In the flowsheet calculations it is assumed that freezing of the FP- and TRU chlorides accounts for the separation of these materials from the product stream; no acknowledgment is granted for the solubility of the FPand TRU chlorides in the molten salt. As was the case for naval fuel, the $\mathrm{Cr}$ - and nickel chlorides are expected to be extracted from the process stream by the molten salt bath, and, as described earlier, $\mathrm{UCl}_{6}$ is soluble in $\mathrm{ZnCl}_{2}$, but once the solution is saturated the balance of the $\mathrm{UCl}_{6}$ will pass through. While $\mathrm{FeCl}_{3}$ forms a stable binary liquid phase with $\mathrm{ZnCl}_{2}$ below the boiling point of $\mathrm{FeCl}_{3}, 588 \mathrm{~K}$, it is unlikely that the solubility of ferric chloride in zinc chloride is extensive at temperatures as high as $673 \mathrm{~K}$. The solubility of $\mathrm{SiCl}_{4}$ in $\mathrm{ZnCl}_{2}$ is not known, but $\mathrm{SiCl}_{4}$ is very volatile, with a normal boiling point of $331 \mathrm{~K}$; consequently, it is unlikely that it is very soluble in $\mathrm{ZnCl}_{2}$. Molybdenum pentachloride is quite volatile, with a normal boiling point of $537 \mathrm{~K}$, and is expected to pass through the molten salt.

Lastly, the manganese and ruthenium chlorides are expected to be extracted by the molten salt due to their low volatilities at the process temperature.

Fractional Condensation: $\mathrm{The}_{\mathrm{FeCl}}, \mathrm{UCl}_{6}, \mathrm{MoCl}_{5}$ and $\mathrm{SiCl}_{4}$ are separated from the process gas stream by fractional condensation in cooled condensers. The first condenser operates at about $450 \mathrm{~K}$, and the $\mathrm{FeCl}_{3}$ and $\mathrm{MoCl}_{5}$ are extracted from the stream in this unit. The gas stream leaving the $450 \mathrm{~K}$ condenser contains primarily $\mathrm{Ar}$ and $\mathrm{Cl}_{2}$, with $\mathrm{UCl}_{6}$ being the third most abundant species. The $\mathrm{UCl}_{6}$ is removed from the process stream in a $300 \mathrm{~K}$ condenser, as was the case for the naval fuels, leaving the noble gas fission products, $\mathrm{I}_{2}$, and cold $\mathrm{SiCl}_{4}$ in the process stream. Separation of the $\mathrm{SiCl}_{4}$ and $\mathrm{I}_{2}$ species is accomplished by fractional condensation at $275 \mathrm{~K}$. Because of the low partial pressures of these two species, the $275 \mathrm{~K}$ condenser does not remove these species from the process stream until they have saturated the gas stream. The partial pressure of $\mathrm{SiCl}_{4}$ in the process stream is about 0.7 torr, while the saturation pressure at $275 \mathrm{~K}$ is about 84 torr, so the mass removed at this unit operation will not be very great.

As was the case for the processing of Zircaloy-clad fuels, material in the fractional condensation condensers would be removed between processing campaigns as a batch operation.

Molten Salt Regeneration/Fluorination: This unit operation and the process variables for operation would be essentially identical to those for Zircaloy-clad fuel processing.

\section{Advantages and Disadvantages of Process}

The INEL has over 90 fuel types in storage that may be grouped into 25 chemical classifications for purposes of defining waste categories. For all of the DOE spent fuels, there are over 150 
types (in the form of over 200,000 handling units), grouped into 53 waste categories. Yucca Mountain Project personnel have estimated that required qualification of a waste form for disposal will cost $\$ 200$ million.

When a series of waste types, such as different categories of spent nuclear fuels, are considered the costs may average about $\$ 60$ million for each. If these requirements persist, there will be a great incentive to convert the fuels into a single waste form for characterization. This could save as much as $\$ 1.4$ billion for INEL fuels and $\$ 3$ billion for all DOE fuels.

Many of the fuels contain substantial quantities of non-radioactive constituents that contribute to the volume of HLW to be dispositioned. For example, naval fuels contain 97 percent non-fission product fuel components. ATR aluminum fuels contain 4.5 percent by weight (1.2 mole percent) fission products. The non-HLW constituents cannot be separated from the fission and transuranic products by aqueous processes. The INEL fuels, if directly canned, will produce some 3745 canisters that will cost some $\$ 400,000$ each to bury.

Criticality, proliferation, and security (classification) issues may result in serious challenges to direct disposal of the naval and other HEU fuels.

If the fuels were to be processed by aqueous dissolution and the HLW converted to a glass form to minimize waste form qualification requirements, chemical additions would increase the number of canisters of 4590 . Also, six to eight processes will be needed at a capital cost of approximately $\$ 3$ billion.

The pyrochemical process will address and resolve all of these issues, resulting in the following advantages.

1. A single, compact process will treat most fuel types and separate the components. The facility capital cost will be approximately $\$ 600$ million. This capital cost will be a wash with that for a direct canning facility, but save $\$ 2.4$ billion versus aqueous processing.

2. A single waste form will be produced, saving some $\$ 1.4$ billion in repository qualification costs over direct canning.

3. The quantity of HLW that will have to be dispositioned will be decreased by a factor of 39 and save $\$ 1.3$ billion in HLW disposal costs while converting the removed constituents to LLW that will cost $\$ 0.25$ billion to dispose.

4. Difficult separations will be possible that otherwise might not be achieved by aqueous processing, e.g., separating zirconium from the HLW constituents in naval fuels.

5. Minimal secondary wastes will be produced, compared with aqueous processing. 
6. The processing rate could be substantially faster than with aqueous processes, saving substantial time and operating costs.

7. The fissile components will be removed, eliminating concerns and issues regarding criticality and theft of fissile material in a repository.

8. The security classification issues regarding naval fuels will be eliminated.

The disadvantages of this new process are related to uncertainties and development needs.

1. Since this is an undeveloped technology, some degree of uncertainty exists as to its viability relative to existing aqueous processes (although some new aqueous head-end processes would have to also be developed if that route were taken). The conceptual process is based on thermodynamic and physicochemical principles and the unit operations are generally based on existing systems that have been applied at ambient temperatures.

2. Approximately 15 years will be needed to bring the technology to a state of effective application. However, the delay in opening a repository presents the U.S. with the opportunity to take advantage of the time to develop such an advanced technology.

3. Materials must be developed or evaluated for the high-temperature process.

4. The unit operations are coupled for the continuous process (that operates on a campaign mode). Issues may be addressed by parallel, backup components.

\section{Technology Status}

Thermodynamic calculations of each unit operational step have shown the feasibility of the process. Specifically, conditions necessary, including control of the process temperature to achieve vaporization of all the constituents of the fuel elements as chlorides so that they can be segregated, were determined by modeling. The ability to segregate specific groupings of the constituents by selective condensation was verified by calculating the composition of the vapor and the condensed phases at selected temperatures. Mass balance flowsheet calculations with conservative assumptions show bulk, non-radioactive constituents, from which the fission products and actinides have been separated, will meet the radionuclide limits of low-level waste.

The segregated and concentrated high-level waste will be in a form that can be converted to a glass, based on development work on fluoride wastes at the ICPP.

Initial laboratory experiments have shown that Zircaloy with an oxide film will readily chlorinate and transport the $\mathrm{ZrCl}_{4}$ vapor at $480^{\circ} \mathrm{C}$ with as little as $0.0067 \mathrm{~atm} \mathrm{Cl}_{2}$ in $1 \mathrm{~atm}$ Ar. Quantitative data indicate a penetration rate for Zircaloy of $2.9 \mathrm{mg} / \mathrm{cm}^{2} / \mathrm{min}(0.011 \mathrm{in} / \mathrm{hr})$ with $0.074 \mathrm{~atm} \mathrm{Cl}_{2}$ 
in $0.74 \mathrm{~atm} \mathrm{Zr}$ at $486^{\circ} \mathrm{C}$ with a $0.22 \mathrm{sec}$ residence contact time. Practical penetration rates at higher temperatures may be reasonably expected; this rate is nearly adequate.

A primary consideration for application and development needs is material for the high temperature chlorination reaction. A similar process used in the manufacture of zirconium has a reaction of chlorine with zircon sand $(\mathrm{ZrSiO} 4)$ blended with graphite powder at $1200^{\circ} \mathrm{C}$ in a graphite, inductively heated vessel. Zirconium dioxide deposited on a substrate by high kineticenergy flame spraying may be another promising material, especially when $\mathrm{CO}$ requirements for oxygen scavenging are small.

Since the chemical process has been modeled on thermodynamic calculations only, a development program will have to be carried out before the concept can be accepted and applied. A development program will establish operating parameters using irradiated fuels, first in laboratory experiments, and then in pilot plant demonstrations of individual unit operations. Verification laboratory tests on irradiated fuels, primarily to track the paths of fission- and transuranic products, will be needed.

A standard project time-line for bringing a new technology into operation indicates 16 years will be required to begin hot processing operations. Approximately $\$ 15$ million development costs will be required; to design and construct a facility will involve approximately $\$ 500$ million capital and $\$ 100$ million operating costs.

Costs, time, and manpower requirements are summarized in the following:

\begin{tabular}{|c|c|c|}
\hline ITEM & TIME & COST \\
\hline $\begin{aligned} & \text { Development: } 15 \text { people } \\
& \text { For Materials } \\
& \text { Pilot Plant }\end{aligned}$ & 6 years & $\begin{array}{l}\$ 10 \text { million } \\
\$ 5 \text { million } \\
\$ 6 \text { million }\end{array}$ \\
\hline $\begin{array}{l}\text { Design, } \\
\text { Construction } \\
\text { and Startup; }\end{array}$ & $\begin{array}{l}14 \text { years, starting with a short } \\
\text { form data sheet } 2 \text { years after } \\
\text { development starts }\end{array}$ & $\begin{array}{l}\$ 100 \text { million operating } \\
\$ 500 \text { million capital }\end{array}$ \\
\hline
\end{tabular}

The design, construction, and startup times are:

o One year short form data sheet requesting funds;

o Three years conceptual and advanced conceptual designs;

o Nine years title design, construction, and SO testing; 
o Two years ORR and startup, beginning one year into SO testing;

o Title design occurs over four years;

o Construction requires four years and begins two years after title design begins.

The operating costs are composed of: the conceptual and advanced conceptual designs, the ORR, and startup activities.

The capital costs are comprised of: the title design, construction, and SO testing activities.

This schedule has an operating facility on line in 2011 at a total cost of $\$ 620$ million, in time for preparing fuels for disposal in a repository. 


\subsection{Pyrochemical Processing of Calcine}

Pyrochemical separation involves several high-temperature unit operations to separate the radioactive from the non-radioactive calcine components in an effort to reduce HLW volume destined for a federal repository.

\section{Process Description}

A schematic diagram of the proposed pyrochemical separation process is shown in Figure 33 for alumina and sodium (calcined sodium liquid waste) calcines and Figure 34 for fluoride-bearing (zirconia, zirconia-sodium, and fluorinel-sodium) calcine. The mass balances for each calcine type are shown in Tables 30, 31, 32, and 33 for alumina, sodium, zirconia, and zirconia-sodium calcine respectively.

The unit operations associated with this flowsheet include: heat treatment of the calcine at $600^{\circ} \mathrm{C}$ to remove volatile components such as $\mathrm{H}_{2} \mathrm{O}, \mathrm{CO}_{\mathrm{x}}$, and $\mathrm{NO}_{\mathrm{x}}$ followed by heat treatment at $1000^{\circ} \mathrm{C}$ to remove $\mathrm{Cs}$ and possibly $\mathrm{Cd}$. Next, the calcine will be chlorinated to remove $\mathrm{Al}, \mathrm{Zr}$, and $\mathrm{B}$ and to prepare the calcine for additional molten salt unit operations. Next, reduction of the actinides in a molten salt matrix will be completed in order to separate the actinide metals from the nonradioactive salt phase. A scavenger metal such as $\mathrm{Zn}$ can be added to the molten salt solution to ensure the formation of a separable metallic phase. The chlorinated off-gas can be re-oxidized and grouted into a low-level waste, and the salt phase from the reduction operation will be sent to an electrowinning operation to recover calcium for the reduction unit operation. The remaining salt phase will be combined with other LLW streams and grouted for disposal. The HLW metallic phase can be vacuum distilled to remove the scavenger metal (if required) and the HLW metals would be re-oxidized and placed in engineered storage awaiting immobilization and final disposal. Options for immobilization include formation of a glass or glass-ceramic waste form. For the purposes of this report, a glass waste form with $28 \mathrm{wt} \%$ waste loading was used.

Additional unit operations will be needed to treat the sodium liquid waste. These operations are not shown in the process flowsheet for sodium calcine. These operations include a freeze crystallization process to remove approximately $67 \%$ of the sodium and $70 \%$ of the $\mathrm{H}_{2} \mathrm{O}$ and an electrohydrolysis operation. 


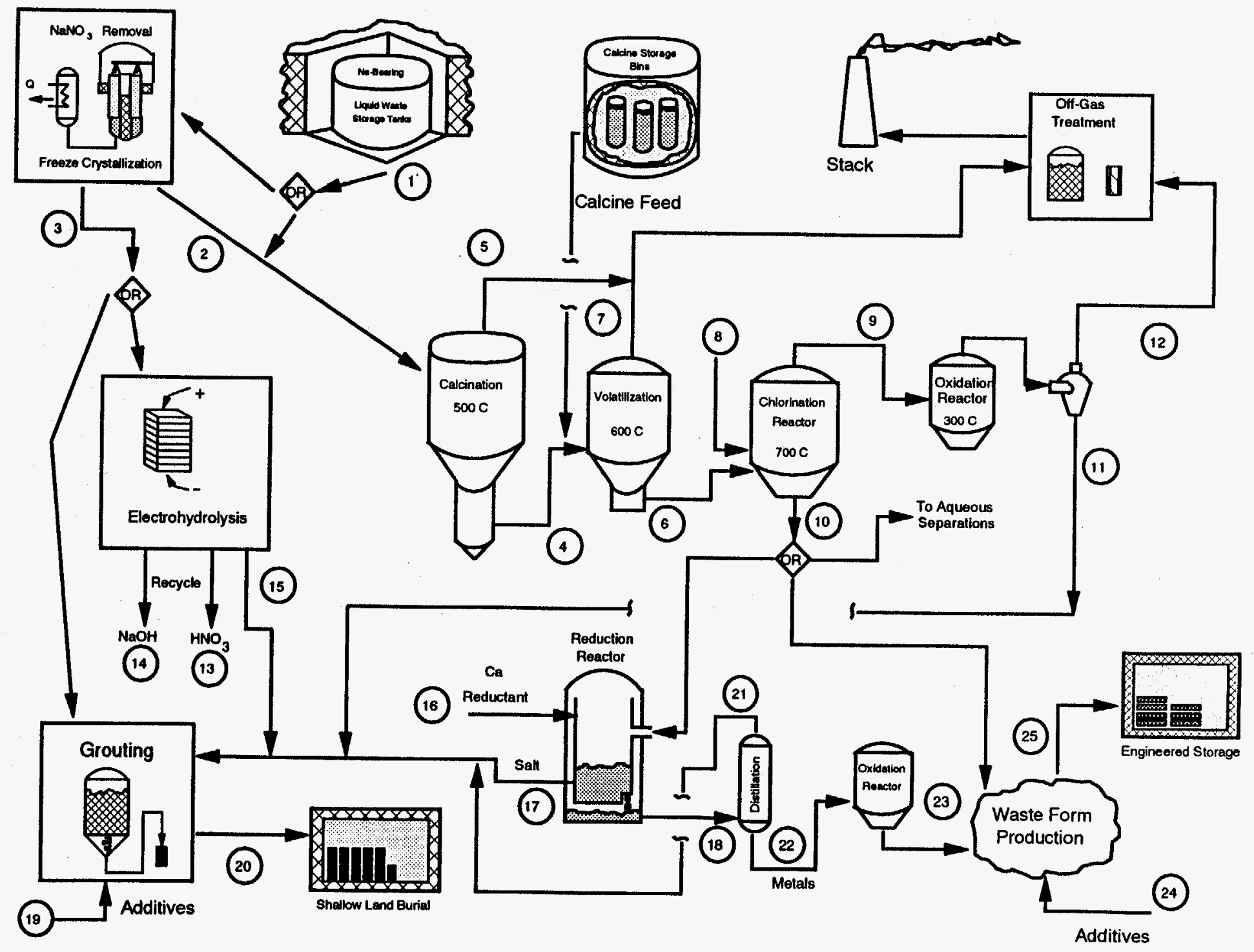

Figure 33. Pyrochemical Separation Process for Alumina and Sodium Calcine 

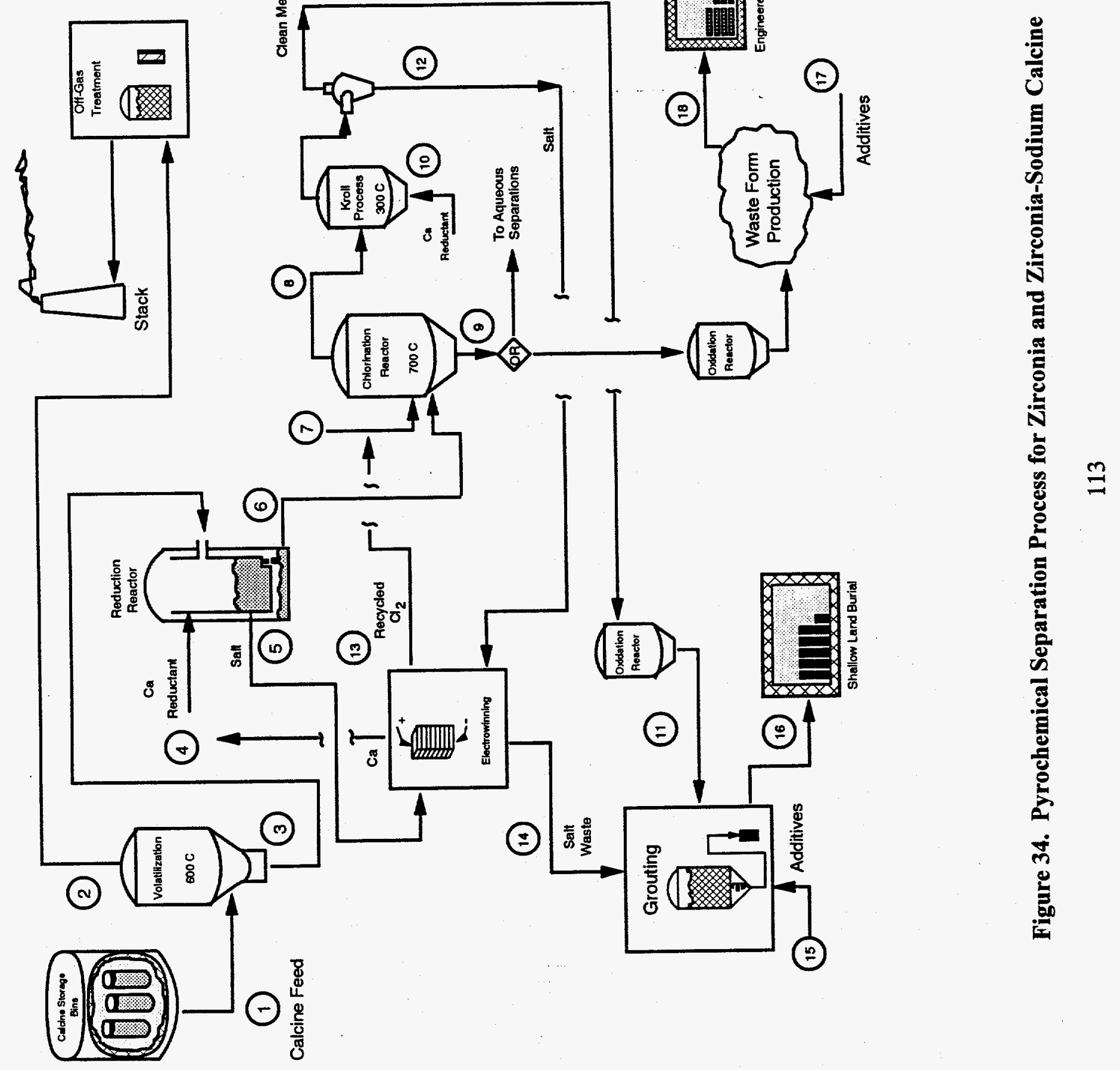
Table 30. Mass Balance for Alumina Calcine

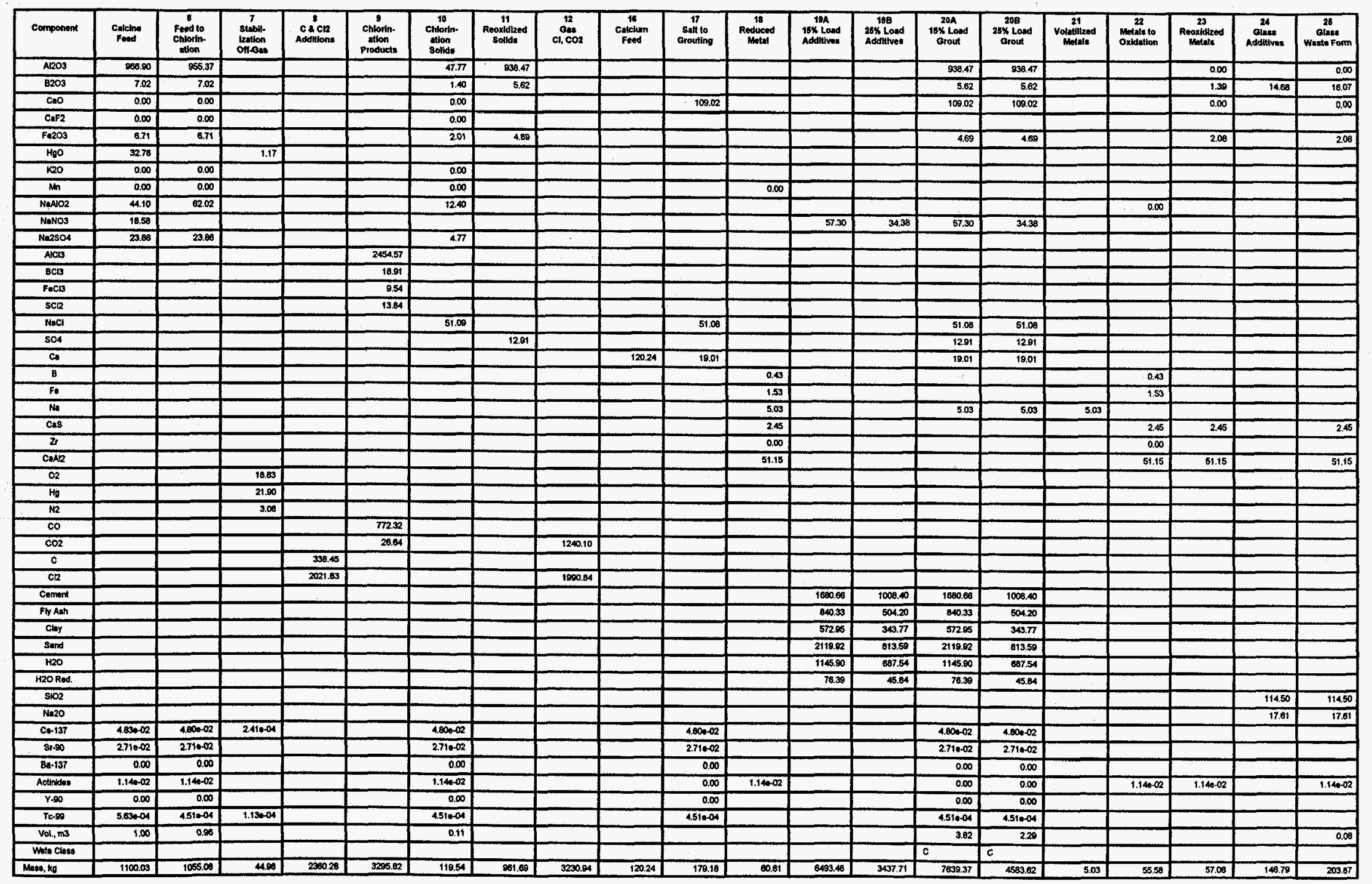


Table 31. Mass Balance for Sodium Calcine

\begin{tabular}{|c|c|c|c|c|c|c|c|c|c|c|c|c|c|}
\hline Component & $\begin{array}{c}1 \\
\begin{array}{c}\text { Tank Waste } \\
\text { Feed }\end{array} \\
\end{array}$ & \begin{tabular}{c|}
2 \\
Waste to \\
Caicination \\
\end{tabular} & $\begin{array}{c}3 \\
\text { NaNO3 } \\
\text { Stream }\end{array}$ & $\begin{array}{c}4 \\
\text { Calcine } \\
\text { Product }\end{array}$ & \begin{tabular}{c|}
5 \\
Calcine \\
Off-Gas
\end{tabular} & \begin{tabular}{c|}
6 \\
Feed to \\
Chlorination
\end{tabular} & $\begin{array}{c}7 \\
\text { Stabilization } \\
\text { Off-Gas }\end{array}$ & \begin{tabular}{|c|}
$\mathrm{C}^{8} \mathrm{Cl}$ \\
Additions \\
\end{tabular} & $\begin{array}{c}\mathbf{c} \\
\begin{array}{c}\text { Chlorination } \\
\text { Products }\end{array} \\
\end{array}$ & $\begin{array}{c}10 \\
\begin{array}{c}10 \\
\text { Chlorination } \\
\text { Solids }\end{array} \\
\end{array}$ & \begin{tabular}{c|c|}
11 \\
Reoxidized \\
Volatile Gas
\end{tabular} & $\begin{array}{c}12 \\
\mathrm{Gas} \\
\mathrm{Cl}, \mathrm{CO} 2 \\
\end{array}$ & $\begin{array}{r}13 \\
\text { Retryci } \\
\text { Hito3 } \\
\end{array}$ \\
\hline \multicolumn{14}{|l|}{$\mathrm{OH}-$} \\
\hline $\mathrm{H}+$ & 1.58 & 1.57 & 6.31E-03 & & & & & & & & & & 1. \\
\hline $\mathrm{Na}$ & 43.61 & 15.70 & 27.91 & & & & & & & & & & \\
\hline $\mathrm{K}$ & 8.02 & 7.98 & $3.21 E-02$ & & & & & & & & & & - \\
\hline$B$ & 0.19 & 0.19 & $7.78 E-04$ & & & & & & & & & & - - \\
\hline A & 17.27 & 17.20 & $6.91 \mathrm{E}-02$ & & & & & & & & & & - \\
\hline $\mathrm{Zr}$ & 0.18 & 0.18 & $7.30 \mathrm{E}-0 \mathrm{9}$ & & & & & & & & & & $\ldots$ \\
\hline $\mathrm{Ca}$ & 2.12 & 2.12 & $8.50 E-03$ & & & & & & & & & & - \\
\hline $\mathrm{Fe}$ & 2.75 & 2.74 & $8.50 E-03$ & & & & & & & & & & \\
\hline $\mathbf{F I}$ & 1.31 & 1.31 & $5.24 E-03$ & & & & & & & & & & $4.98 \mathrm{E}-$ \\
\hline CI & 1.03 & 1.02 & $4.11 E-03$ & & & & & & & & & & $3.91 \mathrm{E}:$ \\
\hline $\mathrm{NO3}$ & 345.49 & 269.30 & 76.18 & & & & & & & & & & $7.15 E+$ \\
\hline 504 & 4.80 & 4.78 & $1.92 \mathrm{E}-02$ & & & & & & & & & & $1133 E=$ \\
\hline $\mathrm{PO} 4$ & 1.80 & 1.80 & $7.22 \mathrm{E}-03$ & & & & & & & & & & 6. \\
\hline UDS & 2.49 & 2.49 & & 2.49 & & 2.49 & & & & 2.49 & & & \\
\hline $\mathrm{H} 2 \mathrm{O}$ & 767.46 & 176.51 & 590.94 & & 937.16 & & & & & & & & -142 \\
\hline $\mathrm{NaNO3}$ & & & & 35.41 & & & & & & & & & -1 \\
\hline KNO3 & & & & 12.59 & & & & & & & & & -1 \\
\hline $\mathrm{Na2O}$ & & & & & & 12.91 & & & & 2.58 & & & - \\
\hline $\mathrm{K} 20$ & & & & & & 5.87 & & & & 1.17 & & & \\
\hline $\mathrm{Ca} 3(\mathrm{PO} 4) 2$ & & & & 2.93 & & 2.93 & & & & 0.59 & & & \\
\hline $\mathrm{CaF2}$ & & & & 1.91 & & 1.99 & & & & 1.91 & & & \\
\hline $\mathrm{CaO}$ & & & & 0.00 & & 0.00 & & & & 0.00 & & & \\
\hline $\mathrm{NaF}$ & & & & 0.84 & & 0.84 & & & & 0.84 & & & \\
\hline $\mathrm{K} 2 \mathrm{SO}_{4}$ & & & & 6.94 & & 6.94 & & & & 1.39 & & & 7 \\
\hline $\mathrm{Na2SO4}$ & & & & 1.42 & & 1.42 & & & & 0.28 & & & \\
\hline $\mathrm{KCl}$ & & & & 0.00 & & 0.00 & & & & 12.18 & & & - \\
\hline $\mathrm{NaCl}$ & & & & 1.69 & & 1.69 & & & & 31.91 & & & \\
\hline $\mathrm{NaAlO2}$ & & & & 8.10 & & 8.10 & & & & 0.81 & & & 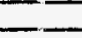 \\
\hline $\mathrm{NaBO} 2$ & & & & 6.50 & & 6.50 & & & & 1.30 & & & $\ldots$ \\
\hline $\mathrm{Al} 2 \mathrm{O} 3$ & & & & 125.04 & & 125.04 & & & & 6.25 & 122.55 & & \\
\hline $\mathrm{B} 203$ & & & & 3.00 & & 3.00 & & & & 0.60 & 5.15 & & 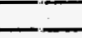 \\
\hline $\mathrm{ZrO2}$ & & & & 0.25 & & 0.25 & & & & 0.12 & 0.12 & & E- \\
\hline $\mathrm{Fe} 2 \mathrm{O} 3$. & & & & 3.92 & & 3.92 & & & & 1.18 & 0.63 & & \\
\hline $\mathrm{CaCl2}$ & & & & & & & & & & 2.52 & & & \\
\hline PCI3 & & & & & & & & & 2.08 & & & & \\
\hline $\mathrm{SCl} 12$ & & & & & & & & & 4.10 & & & & . \\
\hline $\mathrm{AlCl} 3$ & & & & & & & & & 322.54 & & & & \\
\hline $\mathrm{BCl3}$ & & & & & & & & & 17.34 & & & & \\
\hline $\mathrm{FeCl3}$ & & & & & & & & & 5.58 & & & & . \\
\hline $\mathrm{ZrCl4}$ & & & & & & & & & 0.23 & & & & {[} \\
\hline $\mathrm{Fe} 2(\mathrm{SO} 4) 3$ & & & & & & & & & & & 5.31 & & - \\
\hline AIPO4 & & & & & & & & & & & 1.85 & & \\
\hline \multirow{2}{*}{\multicolumn{14}{|c|}{$\frac{\mathrm{KF}}{\mathrm{CaA12}}$}} \\
\hline & & & & & & & & & & & & & \\
\hline \multicolumn{14}{|l|}{$\frac{\mathrm{cos} A}{\mathrm{CaS}}$} \\
\hline \multicolumn{14}{|l|}{$\mathrm{Ca} 3 \mathrm{P} 2$} \\
\hline \multirow{2}{*}{\multicolumn{14}{|c|}{$\begin{array}{l}\mathrm{Z} \mathrm{rB2} \\
\mathrm{SiO2}\end{array}$}} \\
\hline & & & & & & & & & & & & & \\
\hline \multicolumn{14}{|l|}{ Cement } \\
\hline \multirow{2}{*}{\multicolumn{14}{|c|}{$\begin{array}{c}\text { Fly ash } \\
\text { Clay }\end{array}$}} \\
\hline & & & & & & & & & & & & & \\
\hline \multicolumn{14}{|l|}{ Sand } \\
\hline \multicolumn{14}{|l|}{ H20 Reducer } \\
\hline NOX & & & & & 591.78 & & 33.55 & & & & & & \\
\hline $\mathrm{CO}$ & & & & & & & & & 117.86 & & & & \\
\hline $\mathrm{CO} 2$ & & & & & & & & & 4.76 & & & 189.94816 & \\
\hline $\mathrm{C}$ & & & & & & & & 51.84 & & & & & - \\
\hline $\mathrm{Cl} 2$ & & & & & & & & 306.98 & & & & 281.2464 & \\
\hline Actinides & $9.22 \mathrm{E}-02$ & $9.04 \mathrm{E}-02$ & $1.84 E-03$ & $9.04 \mathrm{E}-02$ & & $9.04 \mathrm{E}-02$ & & & & $9.04 E-02$ & & & \\
\hline$C 5-137$ & $4.70 \mathrm{E}-04$ & $4.61 \mathrm{E}-04$ & $9.40 E-06$ & $4.61 \mathrm{E}-04$ & & $4.59 \mathrm{E}-04$ & $2.30 E-06$ & & & $4.59 E-04$ & & & \\
\hline Sr-90 & $2.84 \mathrm{E}-04$ & $2.78 \mathrm{E}-04$ & $5.67 \mathrm{E}-06$ & $2.78 E-04$ & & $2.78 E-04$ & & & & $2.78 E-04$ & & & \\
\hline Te-99 & $.1 .61 \mathrm{E}-21$ & $1.57 \mathrm{E}-21$ & $3.21 \mathrm{E}-23$ & $1.42 E-21$ & $1.57 \mathrm{E}-22$ & 1.13E-21 & $2.83 E-22$ & & & $1.13 \mathrm{E}-21$ & & & \\
\hline $1-129$ & $1.06 \mathrm{E}-02$ & $1.04 \mathrm{E}-02$ & $2.12 E-04$ & $5.19 E-04$ & $9.86 E-03$ & $2.60 \mathrm{E}-05$ & $4.93 \mathrm{E}-04$ & & & $2.60 \mathrm{E}-05$ & & & $201 \mathrm{E}$ \\
\hline Volume, $\mathrm{ml}$ & 1000 & 362.94 & 637.06 & 177.59 & & 153.23 & & & & 56.84 & 113.00 & & 192. \\
\hline Total Mass, gms & \begin{tabular}{|l|}
1200.207929 \\
\end{tabular} & 505.01 & 695.20 & 213.10 & 1528.96 & 183.88 & 33.55 & 358.82 & 474.50 & 68.211 & 135.60 & 471.19 & 215 \\
\hline
\end{tabular}




\begin{tabular}{|c|c|c|c|c|c|c|c|c|c|c|c|c|c|}
\hline $\begin{array}{c}14 \\
\text { Recycle } \\
\mathrm{NaOH}\end{array}$ & $\begin{array}{l}15 \\
\text { Dilute } \\
\text { Waste }\end{array}$ & $\begin{array}{c}16 \\
\text { Calcium } \\
\text { Feed }\end{array}$ & $\begin{array}{c}17 \\
\text { Salts from } \\
\text { Reduction }\end{array}$ & \begin{tabular}{|c|}
18 \\
Reduced \\
Metals \\
\end{tabular} & \begin{tabular}{|c|}
$19 A$ \\
$15 \%$ Load \\
Additives
\end{tabular} & $\begin{array}{c}\text { 19B } \\
25 \% \text { Load } \\
\text { Additives }\end{array}$ & $\begin{array}{c}20 \mathrm{~A} \\
15 \% \text { Waste Lozs } \\
\text { Grouted Waste }\end{array}$ & \begin{tabular}{|c|}
$20 \mathrm{~B}$ \\
$25 \%$ Waste Load \\
Grouted Waste
\end{tabular} & $\begin{array}{c}21 \\
\begin{array}{c}\text { Volatilized } \\
\text { Metals }\end{array} \\
\end{array}$ & \begin{tabular}{c|}
22 \\
Metals to \\
Oxidation
\end{tabular} & \begin{tabular}{c|}
23 \\
Reoxidized \\
Metals
\end{tabular} & $\begin{array}{c}24 \\
\text { Glass } \\
\text { Additions }\end{array}$ & $\begin{array}{c}25 \\
\text { Glass Waste } \\
\text { Form }\end{array}$ \\
\hline \multicolumn{14}{|c|}{ 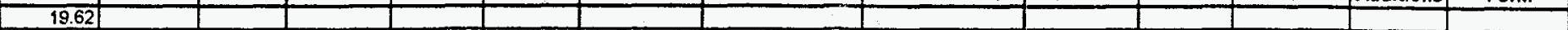 } \\
\hline & $6.31 E-03$ & & & & & & $6.31 E-03$ & $6.31 E-03$ & & & & & \\
\hline 26.52 & 140 & & & 91.74 & & & $13: 3$ & 13.13 & 11.74 & & & & \\
\hline $3.05 E-02$ & $1.60 \mathrm{E}-03$ & & & 2.40 & & & $2.40 \mathrm{E}+10$ & $2.40 \mathrm{E}+00$ & 2.40 & & & & \\
\hline $7.39 E-04$ & $3.89 \mathrm{E}-05$ & & & 0.38 & & & $3.89 E-05$ & $3.89 \mathrm{E}-05$ & & 0.38 & & & \\
\hline $6.56 \mathrm{E}-02$ & $3.45 \mathrm{E}-03$ & & & 0.00 & & & $3.45 \mathrm{E}-03$ & $3.45 E-03$ & & 0.00 & & & \\
\hline $6.93 \mathrm{E}-04$ & $3.65 E-05$ & & & & & & $3.65 E-05$ & $3.65 E-05$ & & & & & \\
\hline 8.07E-03 & $4.25 \mathrm{E}-04$ & 29.25 & 2.00 & & & & $2.00 E+10$ & $2.00 E+00$ & & & & & \\
\hline $8.07 \mathrm{E}-03$ & $4.25 E-04$ & & & 0.87 & & & $4.25 \mathrm{E}-04$ & $4.25 E-04$ & & 0.87 & & & \\
\hline & $2.62 E-04$ & & & & & & $2.62 E-04$ & $2.62 E-04$ & & & & & \\
\hline & $2.06 \mathrm{E}-04$ & & & & & & $2.06 \mathrm{E}-04$ & $2.06 E-04$ & & & & & \\
\hline & $4.67 E+00$ & & & & 11.30 & 6.78 & 11.30 & 6.78 & & & & & \\
\hline & $9.61 E-04$ & & & & & & $9.61 E-04$ & $9.61 E-04$ & & & & & \\
\hline & $3.61 \mathrm{E}-04$ & & & & & & $3.61 E-(24$ & $3.61 \mathrm{E}-04$ & & & & & \\
\hline & & & 2.49 & & & & 2.488 & 2.488 & & & & & \\
\hline 142.54 & 285.08 & & & & 226.00 & 135.60 & 226.00 & 135.60 & & & & & \\
\hline & & & & & & & & & & & & & \\
\hline & & & & & & & & & & & & & \\
\hline & & & & & & & & & & & & & \\
\hline & & & & & & & & & & & & & \\
\hline & & & & & & & & & & & & & \\
\hline & & & 1.91 & & & & 1.91 & 1.91 & & & & & \\
\hline & & & 22.56 & & & & 2266 & 22.56 & & & & & \\
\hline & & & 0.84 & & & & 0.14 & 0.84 & & & & & \\
\hline & & & & & & & & & & & & & \\
\hline & & & & & & & & & & & & & \\
\hline & & & 10.66 & & & & 10.66 & 10.66 & & & & & \\
\hline & & & 8.91 & & & & 8.91 & 8.91 & & & & & \\
\hline & & & & & & & & & & & & & \\
\hline & & & & & & & & & & & & & \\
\hline & & & & & & & 12255 & 122.55 & & & 0.00 & & 0.00 \\
\hline & & & & & & & 5.5 & 5.15 & & & 1.29 & 2.37 & 3.66 \\
\hline & & & & & & & 0.83 & 0.63 & & & 0.12 & & 0.12 \\
\hline & & & & & & & 0.12 & 0.12 & & & 1.18 & & 1.18 \\
\hline & & & 25.49352 & & & & 25.49 & 25.49 & & & & & \\
\hline & & & & & & & & & & & & & \\
\hline & & & & & & & & & & & & & \\
\hline & & & & & & & & & & & & & \\
\hline & & & & & & & & & & & & & \\
\hline & & & & & & & & & & & & & \\
\hline & & & & & & & & & & & & & \\
\hline & & & & & & & 5.31 & 5.31 & & & & & \\
\hline & & & & & & & 1.35 & 1.85 & & & & & \\
\hline & & & 0 & & & & 0.0 & 0.00 & & & & & \\
\hline & & & & 6.23 & & & & & & 6.23 & 6.23 & & 6.23 \\
\hline & & & & 0.72 & & & & & & 0.72 & 0.72 & & 0.72 \\
\hline & & & & 0.34 & & & & & & 0.34 & 0.34 & & 0.34 \\
\hline & & & & 0.11 & & & & & & 0.11 & & & \\
\hline & & & & & & & & & & & & 23.32 & 23.32 \\
\hline & & & & & 331.47 & 198.88 & 33147 & 198.88 & & & & & \\
\hline & & & & & 965.73 & 99.44 & 165.73 & 99.44 & & & & & \\
\hline & & & & & 113.00 & 67.80 & 113.00 & 67.80 & & & & & \\
\hline & & & & & 418.10 & 160.46 & 418.10 & 160.46 & & & & & \\
\hline & & & & & 15.07 & 9.04 & 15.07 & 9.04 & & & & & \\
\hline & & & & & & & & & & & & & \\
\hline & & & & & & & & & & & & & \\
\hline & & & & & & & & & & & & & \\
\hline & & & & & & & & & & & & & \\
\hline & & & & & & & & & & & & & \\
\hline $1.75 \mathrm{E}-03$ & $9.22 \mathrm{E}-05$ & & $9.04 \mathrm{E}-04$ & $8.95 \mathrm{E}-02$ & & & $9.92 \mathrm{E}-04$ & $9.92 E-04$ & & $8.95 \mathrm{E}-02$ & $8.95 \mathrm{E}-02$ & & $8.95 \mathrm{E}-02$ \\
\hline $8.93 E-06$ & $4.70 \mathrm{E}-07$ & & $4.59 E-04$ & & & & $4.59 E-04$ & $4.59 \mathrm{E}-04$ & & & & & \\
\hline $5.39 \mathrm{E}-06$ & $2.84 \mathrm{E}-07$ & & $2.78 E-04$ & & & & $2.78 \mathrm{E}-04$ & $2.78 \mathrm{E}-04$ & & & & & \\
\hline $3.05 E-23$ & $1.61 E-24$ & & & $1.13 \bar{E}-21$ & & & $0.00 E+00$ & $0.00 E+00$ & & $1.13 \mathrm{E}-21$ & $1.13 \mathrm{E}-21$ & & $1.13 E-21$ \\
\hline & $1.06 E-05$ & & $2.60 \mathrm{E}-05$ & & & & $3.66 \mathrm{E}-05$ & $3.66 \mathrm{E}-05$ & & & & & \\
\hline 161.36 & 291.16 & & & & & & 753.33 & 452.00 & & & & & 13.72 \\
\hline 188.79 & 291.16 & 29.25 & 74.86 & 22.87 & 1280.66 & 678.00 & 150666 & 904.00 & 14.13 & 8.74 & 9.97 & 25.69 & 35.66 \\
\hline
\end{tabular}




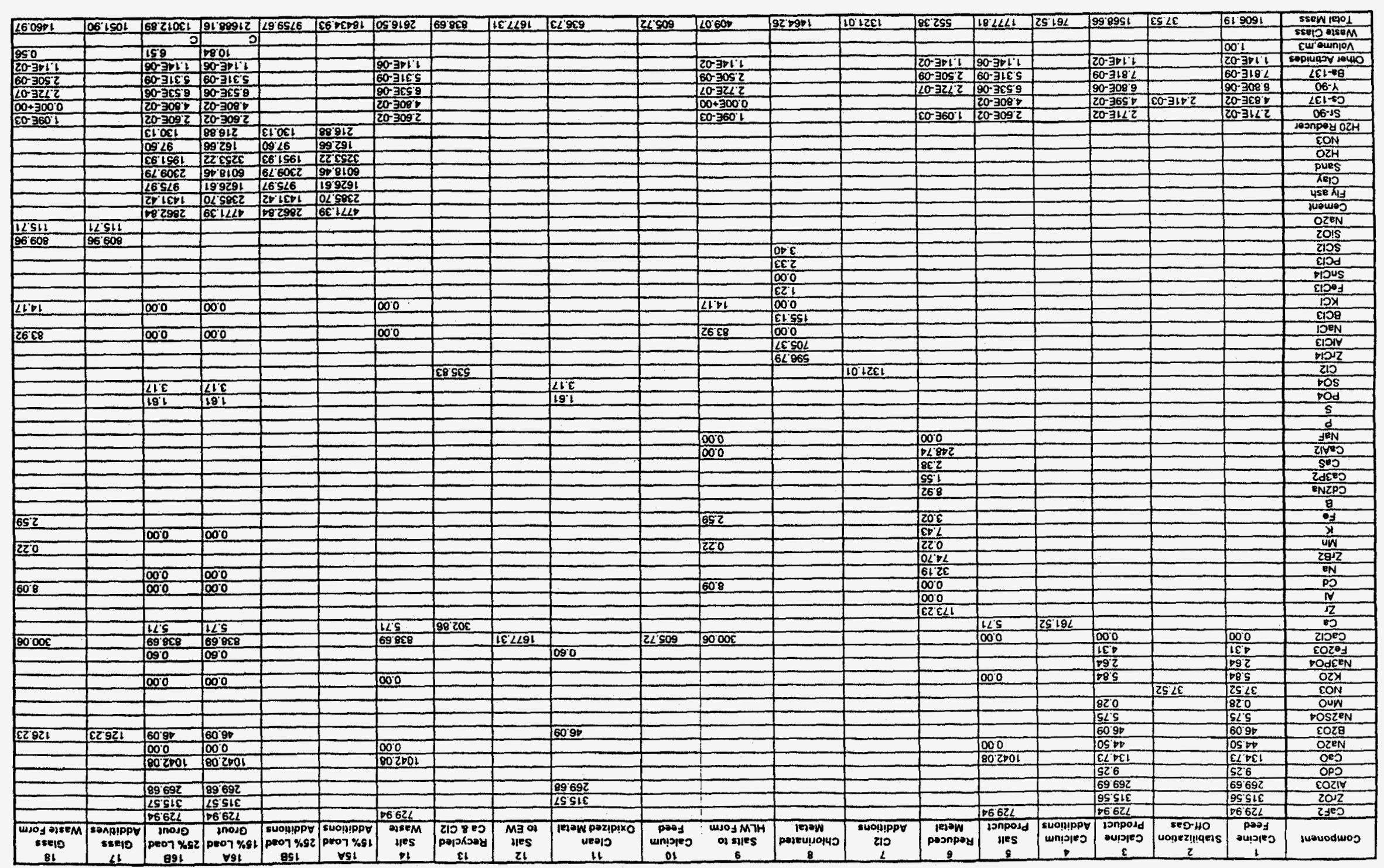

วu!ว 



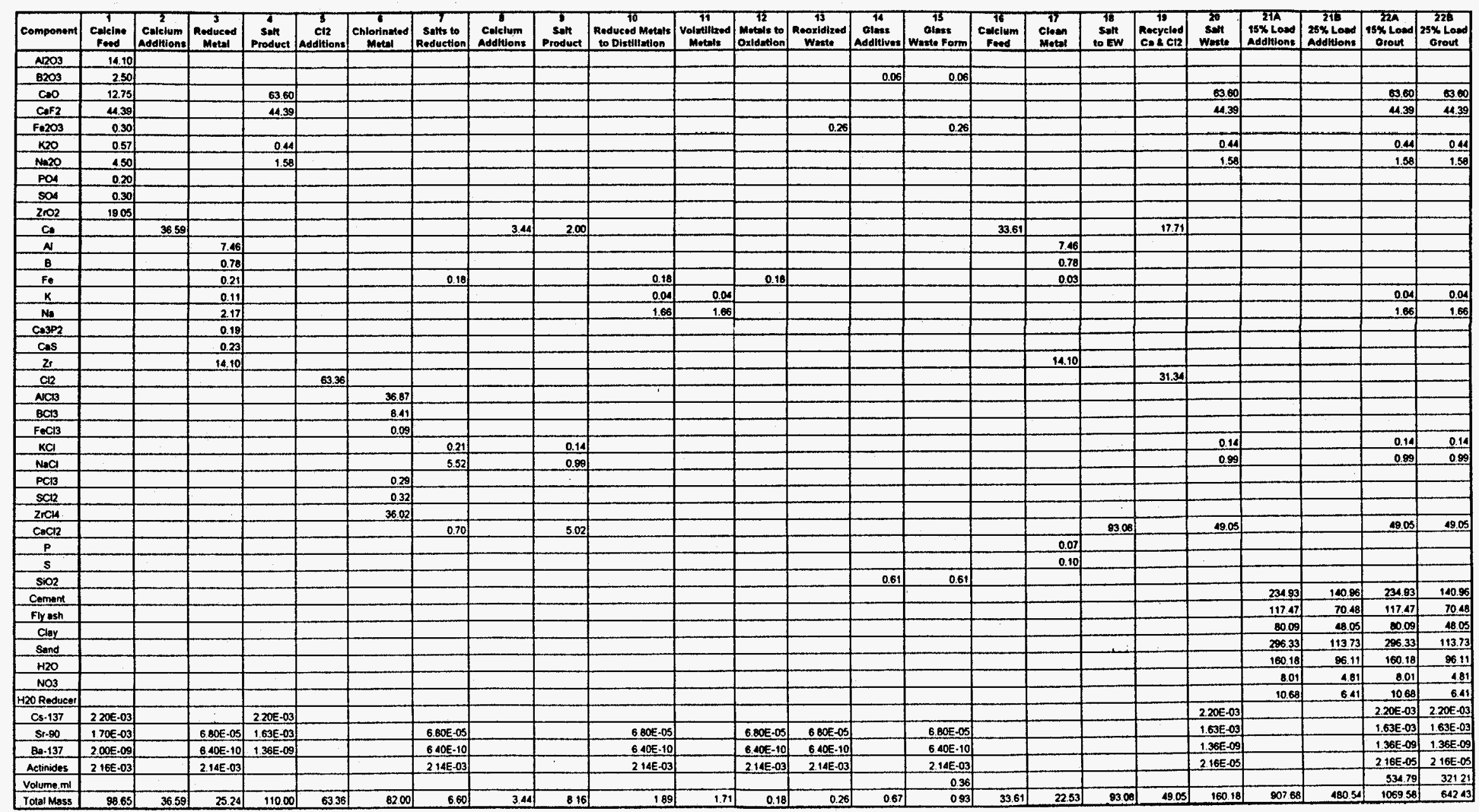


The remaining radioactive waste from the separated sodium waste will be blended with aluminum nitrate to obtain a specific mole percentage of sodium plus potassium in the sodium calcine.

Implementation of the pyrochemical separations process can reduce the amount of HLW requiring disposal by one to two orders of magnitude. The advantage of the pyrochemical process compared to other HLW separation methods is the small quantity of additives needed to achieve separations. Due to the limited amount of additives, relatively small quantities of LLW are generated and the bulk of the radionuclides end up in the HLW. The disadvantages of this process include high processing temperatures and many undemonstrated unit operations. However, application of this processing method to ICPP HLW calcine is potentially very cost effective.

Assumptions Used in Completing Mass Balance Calculations

A significant amount of experimental and theoretical work has been completed to determine the feasibility of the pyrochemical process. The mass balances shown in the Tables were completed using experimental results where available. Where actual experimental data were lacking, a thermodynamic equilibrium code was used to determine which reactions were occurring. This computer code is called the "Facility for the Analysis of Chemical Thermodynamics," or just $\mathrm{F}^{*} \mathrm{~A}^{*} \mathrm{C}^{*} \mathrm{~T}^{*}$. Kinetic data from the literature and best engineering judgment were then used to determine percent yields. The assumptions used for the reactions and yields associated with the chlorination operation to treat alumina and sodium calcine are shown in Table 34.

Zirconia and zirconia-sodium calcine can be chlorinated and reduced in a continuous oxide reduction system (CORS). In the CORS, metallic oxides are reduced using a reductant (calcium) metal in a molten salt (calcium chloride). The salt is continuously regenerated through the addition of chlorine gas. Lawrence Livermore National Laboratory (LLNL) is developing a CORS reactor. It is not known if there will be sufficient metals resulting from the reduction to form a congealed metal phase and the use of a scavenger metal such as zinc may be required. All of the reduction reactions and yields were determined from the $\mathrm{F}^{*} \mathrm{~A}^{*} \mathrm{C}^{*} \mathrm{~T}$ computer code.

$\mathrm{F}^{*} \mathrm{~A} \mathrm{C}^{*} \mathrm{~T}$ calculates the equilibria of chemical systems by a technique known as free energy minimization. The free energy of the system is calculated based upon the specified stoichiometric compositions. The computer determines the possible solution species and varies the molar quantities. The Gibbs free energy is recalculated after each adjustment of the stoichiometric coefficients until the free energy of the system is at a minimum. The computed mole percentages are directly applied to the mass balance of the reduction operation.

In order to produce a suitable waste glass, the metallic HLW will be converted to oxides. The reoxidation reaction occurs readily at elevated temperatures in the presence of oxygen. All reactions are verified using the $\mathrm{F}^{*} \mathrm{~A}^{*} \mathrm{C}^{*} \mathrm{~T}$, program. The assumed waste glass formulation is $65.6 \mathrm{wt} \% \mathrm{SiO}_{2}, 27.8 \mathrm{wt} \% \mathrm{HLW}$, and $6.6 \mathrm{wt} \% \mathrm{~B}_{2} \mathrm{O}_{3}$. The glass formulation is based on previous glass form work at the ICPP and best engineering judgment. 
Table 34. Assumed Chlorination Reactions and Yields

\begin{tabular}{|c|c|}
\hline REACTION & $\begin{array}{l}\text { PERCENT } \\
\text { YIELD }\end{array}$ \\
\hline $2 \mathrm{Na} 2 \mathrm{O}+\mathrm{C}+2 \mathrm{Cl} 2 \rightarrow 4 \mathrm{NACl}+\mathrm{CO} 2(\mathrm{~g})$ & 80 \\
\hline $2 \mathrm{~K} 2 \mathrm{O}+\mathrm{C}+2 \mathrm{CL} 2 \rightarrow 4 \mathrm{KCl}+\mathrm{CO} 2(\mathrm{~g})$ & 80 \\
\hline $2 \mathrm{Ca} 3(\mathrm{PO} 4) 2+16 \mathrm{C}+12 \mathrm{Cl} 2+6 \mathrm{CaCl} 2+4 \mathrm{PC} 13+16 \mathrm{CO}(\mathrm{g})$ & 8 \\
\hline $\mathrm{Na} 2 \mathrm{SO} 4+4 \mathrm{C}+2 \mathrm{Cl} 2 \rightarrow 2 \mathrm{NaCl}+\mathrm{SC} 12(\mathrm{~g})+4 \mathrm{CO}(\mathrm{g})$ & 80 \\
\hline $\mathrm{K} 2 \mathrm{SO}_{4}+4 \mathrm{C}+2 \mathrm{Cl} 2->2 \mathrm{KCl}+\mathrm{SC}_{12}(\mathrm{~g})+4 \mathrm{CO}(\mathrm{g})$ & 80 \\
\hline $2 \mathrm{NaAlO} 2+4 \mathrm{C}+4 \mathrm{C} 12 \rightarrow 2 \mathrm{NaCl}+2 \mathrm{AlCl} 3(\mathrm{~g})+4 \mathrm{CO}(\mathrm{g})$ & 90 \\
\hline $2 \mathrm{NaBO} 2+4 \mathrm{C}+4 \mathrm{C} 12->2 \mathrm{NaCl}+2 \mathrm{BC} 13(\mathrm{~g})+4 \mathrm{CO}(\mathrm{g})$ & 80 \\
\hline $\mathrm{Al} 203+3 \mathrm{C}+3 \mathrm{C} 12->2 \mathrm{AlCl} 3(\mathrm{~g})+3 \mathrm{CO}(\mathrm{g})$ & 95 \\
\hline $\mathrm{B} 2 \mathrm{O} 3+3 \mathrm{C}+3 \mathrm{C} 12-->2 \mathrm{BC} 13(\mathrm{~g})+3 \mathrm{CO}(\mathrm{g})$ & 80 \\
\hline $\mathrm{Fe} 203+3 \mathrm{C}+3 \mathrm{C} 12--.2 \mathrm{FeCl} 3(\mathrm{~g})+3 \mathrm{CO}(\mathrm{g})$ & 70 \\
\hline $\mathrm{ZrO} 2+2 \mathrm{C}+2 \mathrm{C} 12 \rightarrow \mathrm{ZrCl} 4(\mathrm{~g})+2 \mathrm{CO}(\mathrm{g})$ & 50 \\
\hline $2 \mathrm{CaO}+\mathrm{C}+2 \mathrm{C} 12->2 \mathrm{CaCl} 2+\mathrm{CO} 2$ & 80 \\
\hline
\end{tabular}

The salt product and unreduced components resulting from the CORS will be transported to an electrowinning process. Electrowinning is a unit operation which splits $\mathrm{CaCl}_{2}$ into calcium metal and $\mathrm{Cl}_{2}$. The $\mathrm{Ca}$ and $\mathrm{Cl}_{2}$ will then be recycled to the reduction and chlorination processes. The assumed separation was $50 \%$. The residual salt from the electrowinning operation will be blended into a grout. The mass balance was calculated using both a 15 and $25 \mathrm{wt} \%$ waste loading for the LLW grout.

\section{Unit Operations Descriptions}

Heat treatment is performed at $600^{\circ} \mathrm{C}$ to remove $\mathrm{NO}_{\mathrm{x}}, \mathrm{CO}_{\mathrm{x}}$, and $\mathrm{H}_{2} \mathrm{O}$. This can be done in a fluidized bed with air purge. Typical residence times for calcine range from 20 to 45 minutes for near-complete stabilization. This unit operation has been studied for the glass-ceramic process.

Treatment is performed at $1000^{\circ} \mathrm{C}$ to remove $\mathrm{Cs}$ and possibly $\mathrm{Cd}$. This can done in either a fluidized or packed bed with air or argon purge. Removal efficiencies of up to $97 \%$ for Cs have been demonstrated.

Fabrication materials for the heat treatment operation will be stainless-steel lined with a refractory and are similar to the fluidized bed calciners designed and tested at the ICPP. 
The reduction operation is expected to take place at temperatures less than $800^{\circ} \mathrm{C}$ to avoid volatilization of radionuclides from the molten salt solution and to increase the number of available fabrication materials. In order to complete the reduction operation at $800^{\circ} \mathrm{C}$, the addition of calcium chloride or pretreatment of the calcine with a chlorinating agent such as a chlorine/carbon mixture may be necessary to decrease the melting point of the calcine.

Reduction can be accomplished in a magnesium oxide crucible equipped with a stirrer. Calcium metal can be added to the molten salt solution to reduce the actinides to the metallic phase. A scavenger metal such as $\mathrm{Zn}$ is necessary to obtain a separable metallic phase. Without the use of $\mathrm{Zn}$ or another scavenger metal, the metallic phase may not congeal and will be dispersed within the salt phase. The metallic phase will be separated from the salt phase by decanting the heavier metallic phase from the bottom of the crucible. The salt phase will be removed from the top of the crucible.

A unit operation similar to the one described above is currently under development at LLNL. The reactor is referred to as a CORS reactor. It is currently operational on the kilogram scale.

Chlorination can be accomplished in a fluidized or packed bed at a temperature of 600 to $800^{\circ} \mathrm{C}$ using a mixture of $\mathrm{Cl}_{2}$ and $\mathrm{CO}$ gas as the chlorinating agent. Research and development is required to determine the optimum temperature for chlorination and to develop adequate construction materials. Similar chlorination unit operations have been identified in the zirconium and in the titanium industry. The zirconium industry utilizes chlorination to separate zirconium tetrachloride from impurities. The zirconium chlorination takes place in a graphite fluidized bed at $1000^{\circ} \mathrm{C}$. In the titanium industry, chlorination takes place at approximately $1000^{\circ} \mathrm{C}$ in a firebrick-lined mild-steel vessel.

Scoping chlorination studies have been completed at the ICPP. These studies have shown that a separation of radioactive and non-radioactive calcine components is possible for alumina calcine. The chlorination of calcium fluoride-bearing calcines can serve as a pre-treatment for other pyrochemical separation unit operations, such as molten salt reduction. Studies have shown that chlorination of calcium fluoride-bearing calcines converts the calcium fluoride to calcium chloride and reduces the melting temperature of the calcine from $1300^{\circ} \mathrm{C}$ to $850^{\circ} \mathrm{C}$.

If chlorinating reagents are added to the reactor vessel simultaneously with the reducing agent, calcium, then possibly chlorination could be accomplished simultaneously with reduction in the CORS reactor.

Re-Oxidation of chlorinated calcine components can be accomplished in a fluidized bed at a temperature of 500 to $700^{\circ} \mathrm{C}$. A unit operation similar to this is used in the titanium industry to remove chlorine from titanium and to replace it with oxygen. The chlorine is recycled and used in the chlorination step in this process. A similar use for chlorine is desirable in this process to reduce chlorine emissions and to reduce off-gas treatment system capacity. 
Electrowinning is accomplished in an electrochemical cell in a molten salt solution using a nondepleting anode. A current is introduced into the anode and the desired salt component is reduced and collected at the cathode.

Vacuum distillation involves heating a mixture of metals to near the boiling point and pulling a vacuum to separate the volatile from the non-volatile components. This operation is required to remove the scavenger metal $\mathrm{Zn}$ in the reduction step.

The HLW generated from the pyrochemical process will need to be immobilized prior to disposal. Several waste form options are possible. The most favorable is glass or glass-ceramic. The glass form will require the least amount of additional research and development, but will reduce some of the gains made from using the pyrochemical process as the waste loading will be somewhere between 20 and $30 \mathrm{wt} \%$. The glass-ceramic waste form will achieve a HLW volume reduction over glass, but will require a substantial amount of research and development to provide a viable process.

\section{Technology Status}

The pyrochemical process has a substantial amount of uncertainty associated with it. Many of the unit operations will require an oxygen deficient atmosphere to be successful. Demonstrated pyrochemical operations at other sites maintain an oxygen atmosphere of less than $5 \mathrm{ppm}$. This pure atmosphere may be difficult to maintain using remote equipment on the engineering scale.

At this point in the development program, it appears that the process can be made quite flexible in that a number of different feed stocks can be processed. In order to accommodate various feed stocks and feed rates, a substantial surge capacity will be required. The chemistry for each of the calcine types will vary significantly and each operation will need to be designed to allow for large variations in flow rate. For example, separation of $90 \%$ of the inert materials in alumina calcine can be realized in the chlorination operation. On the other hand, calcium fluoride-bearing calcine components can be separated in the reduction operation. The design of a process to handle large variations in feed stock and flow rates will be a significant challenge. Several of these unit operations have been demonstrated on the industrial scale in the zirconium and titanium industries. The potential pay backs are high, but the uncertainties are also high.

Experiments with non-radioactive calcine have been completed to show that high-temperature treatment $\left(1000^{\circ} \mathrm{C}\right)$ of $\mathrm{HLW}$ calcine to remove cesium and cadmium may be achievable. The high-temperature treatment of calcine has been demonstrated to drive off nitrates and other volatiles. A limited amount of study has demonstrated the ability of thermal treatment to drive off cesium and cadmium from the calcine. Most of the developmental work has been completed with cold calcine. Up to $97 \%$ of the cesium has been removed from cold calcine at $1000^{\circ} \mathrm{C}$ in five hours. High-temperature heat treatment to remove $\mathrm{Cs}$ and $\mathrm{Cd}$ has also been demonstrated using actual radioactive calcine. Both of these scoping studies have been completed on the 1 to 5 gram scale. Larger-scale testing will be required to demonstrate the unit operations. 
A gross separation between radioactive and non-radioactive alumina calcine components can be achieved via calcine chlorination at $600^{\circ} \mathrm{C}$. Chlorination scoping tests have been completed. Approximately $90 \%$ of the aluminum in alumina calcine was removed using chlorination alone. Testing with calcium fluoride bearing calcines has shown that chlorination can serve to reduce the melting point of the calcine to allow molten salt separation operations to be completed without the addition of additional salts to reduce the melting point. All chlorination work completed to date has been done with simulated calcines.

Reduction tests have been performed at LLNL and results will be made available once they are received. All testing was completed with simulated zirconia calcine. All other unit operations identified for the pyrochemical separations process have not been demonstrated on ICPP calcined waste. However, all of these steps have been demonstrated and are feasible for use in industrial separations processes. Testing on these other unit operations will be initiated once the chlorination and reduction unit operations are deemed feasible.

Most of the equipment required to be used in the pyrochemical process has been demonstrated in industry. The equipment types include fluidized beds, packed beds, high-temperature molten salt reactors, solid/gas separators, and high-temperature vacuum distillation equipment. Fabrication materials for several of the unit operations will need to be developed. In industry, several operations use fire-brick lined vessels. This may be unacceptable for the pyrochemical process as spent fire brick can be a substantial addition to the waste generated from the process. Materials of construction may include fire brick- or refractory-lined steel vessels. Possible refractory materials that are resistant to erosion include: high-purity alumina, tungsten, magnesia, and others. 
As a summary, the unit operations involved in the pyrochemical process development program are shown in Table 35 with the associated development issues.

Table 35. Development Issues Associated with the Pyrochemical Process

\begin{tabular}{|c|c|c|}
\hline UNIT OPERATION & ISSUES & $\begin{array}{c}\text { DEVELOPMENT } \\
\text { TIME } \\
\end{array}$ \\
\hline \multicolumn{3}{|l|}{ Heat-Treatment: } \\
\hline $\begin{array}{l}600^{\circ} \mathrm{C} \text { (Intermediate } \\
\text { Temperature) }\end{array}$ & $\begin{array}{l}\text { Determination of optimum temperature, } \\
\text { fluidization velocity, and residence times. }\end{array}$ & 2 years \\
\hline $\begin{array}{l}1000^{\circ} \mathrm{C} \text { (High } \\
\text { Temperature) }\end{array}$ & $\begin{array}{l}\text { Determine optimum equipment setup, } \\
\text { temperature, purge rates, residence times, and } \\
\text { fabrication materials. }\end{array}$ & 1 year \\
\hline Chlorination & $\begin{array}{l}\text { Determine optimum reaction temperature, } \\
\text { chlorinating reagents, solid/gas separation } \\
\text { equipment, fabrication materials, and verify } \\
\text { separation obtained using this unit operation. }\end{array}$ & 2 years \\
\hline Reduction & $\begin{array}{l}\text { Determine optimum reaction temperature, } \\
\text { reducing metals, metal/salt separation, } \\
\text { continuous or batch process, equipment setup, } \\
\text { and fabrication materials. }\end{array}$ & 2 years \\
\hline Re-Oxidation & $\begin{array}{l}\text { Determine reaction temperature, feasibility of } \\
\text { recycling chlorine, and develop gas-solid } \\
\text { separation scheme. }\end{array}$ & 2 years \\
\hline Ėlectrowinning & $\begin{array}{l}\text { Determine reaction temperature, applicability of } \\
\text { existing technology, and possible efficiencies. }\end{array}$ & 1 year \\
\hline Vacuum Distillation & $\begin{array}{l}\text { Determine distillation temperature, vacuum } \\
\text { required, scavenger metal(s), and fabrication } \\
\text { materials. }\end{array}$ & 2 years \\
\hline Immobilization & $\begin{array}{l}\text { Determine waste form, develop suitable } \\
\text { formulations, and verify equipment required. }\end{array}$ & 3 years \\
\hline
\end{tabular}




\subsection{Aqueous Processing of Calcine}

An option has been developed for the separation of actinides, $\mathrm{Sr}, \mathrm{Cs}$, and $\mathrm{Tc}$ from dissolved calcine utilizing solvent extraction and ion exchange technologies. The conceptual process flow diagram is shown in Figure 35 and the associated material balance is listed in Table 36. This mass balance is based on the processing of zirconium calcine.

\section{Process Description}

Retrieved calcine is dissolved in a nitric acid solution. Actinides are extracted from the dissolved calcine using the TRUEX Process. Sr and Tc are extracted from the dissolved calcine using the SREX Process. Cs is then removed from the dissolved calcine by ion exchange. Pending calcine characterization, heavy metal removal may also be necessary. The resulting raffinate (low-level waste) is denitrated and grouted for near-surface disposal. The actinides can be converted to a waste form for engineered storage or burned within the Integral Fast Reactor (IFR). The Cs loaded ion exchange resin, $\mathrm{Sr}$, and $\mathrm{Tc}$ are converted to a waste form for engineered storage. The alternative presented in Figure 35 is based on combining the actinides, Sr, Cs, and undissolved calcine for high-level waste immobilization.

The main advantage of this process is the reduction in quantity of high-level waste requiring disposal in a repository. The process for converting calcine directly to a glass ceramic waste form results in approximately 0.44 liters of waste form per $\mathrm{kg}$ of calcine processed $(70 \%$ solids loading). The aqueous separations flowsheet results in approximately 0.13 liters of waste form per $\mathrm{kg}$ of calcine processed. This is a $70 \%$ reduction in high-level waste volume that could significantly reduce the repository costs. Another advantage of this process is that a similar flowsheet can be used for the processing of sodium waste and dissolved fuel.

A disadvantage of this process is the low-level waste that is generated. Approximately 1.1 liters of low-level waste grout is generated for each $\mathrm{kg}$ ( 0.7 liters) of calcine processed. In addition, liquid waste will be generated that will require disposal in the PEW evaporator. 


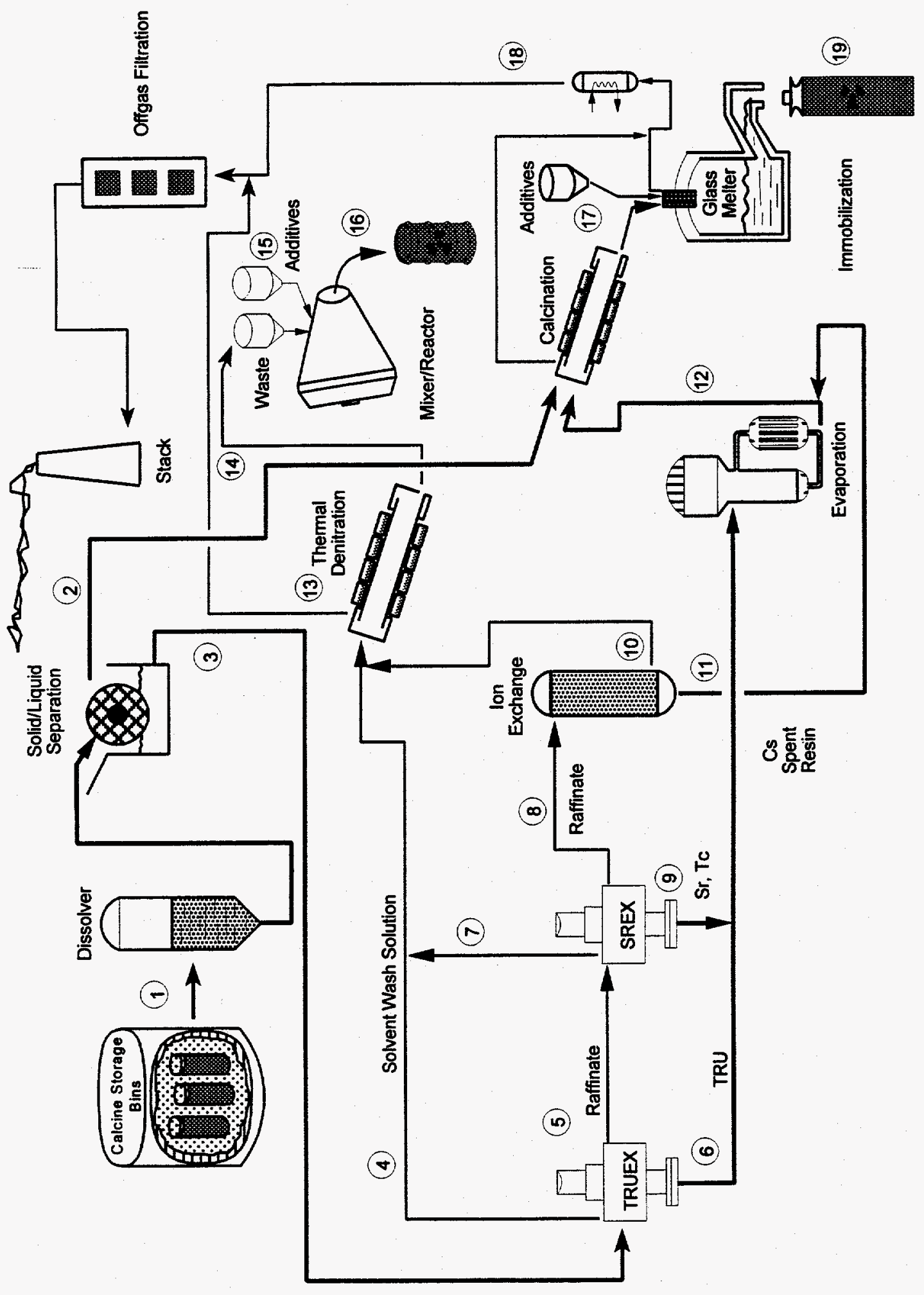

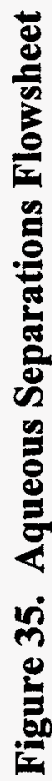


Table 36. Aqueous Separations Mass Balance (Zr Calcine)

\begin{tabular}{|c|c|c|c|c|c|c|c|c|c|c|c|c|c|c|c|c|c|c|c|}
\hline Componont & 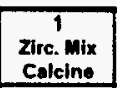 & $\begin{array}{c}2 \\
\text { solld } \\
\text { Woetto }\end{array}$ & $\begin{array}{c}3^{3} \\
\text { Liquild } \\
\text { Waste }\end{array}$ & $\begin{array}{c}\text { Solvont } \\
\text { Wash Soln }\end{array}$ & $\begin{array}{c}3 \\
\text { TRUEx } \\
\text { Raffinate }\end{array}$ & $\begin{array}{c}6 \\
\text { TRUEX } \\
\text { Product }\end{array}$ & $\begin{array}{l}\text { SREX Sovon } \\
\text { Wauh Soln }\end{array}$ & \begin{tabular}{|c|}
8 \\
SREX \\
Rafflinate
\end{tabular} & \begin{tabular}{|c|}
8 \\
SREX \\
Product
\end{tabular} & $\begin{array}{c}10 \\
\text { Ion Exchange } \\
\text { Product }\end{array}$ & $\begin{array}{c}11 \\
\text { Lon Exchanges } \\
\text { Resin }\end{array}$ & $\begin{array}{c}12 \\
\text { concentutod } \\
\text { HLW }\end{array}$ & $\mathrm{HW}_{\text {MOX }}^{13}$ & $\begin{array}{c}14 \\
\text { Donltitated } \\
L L W\end{array}$ & $\begin{array}{c}15 \\
\text { Grout } \\
\text { Addilituos }\end{array}$ & $\begin{array}{c}16 \\
\text { LLw } \\
\text { Grout } \\
\end{array}$ & \begin{tabular}{|c|}
17 \\
Glans \\
Fill \\
\end{tabular} & $\begin{array}{c}18 \\
\text { HLW } \\
\text { NOX }\end{array}$ & $\begin{array}{c}18 \\
\text { HLW } \\
\text { Glaw: } \\
\end{array}$ \\
\hline$\frac{\mathrm{H}+}{\mathrm{A}}$ & 0.08 & & $\frac{0.03054}{0.08861}$ & $3.75 E-05$ & \begin{tabular}{|l}
0.02936 \\
0.08844 \\
\end{tabular} & \begin{tabular}{|l|}
$1.59 E-03$ \\
$1.89 E-11$ \\
\end{tabular} & & 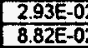 & & $\begin{array}{r}2.932-02 \\
8.82 E-02 \\
\end{array}$ & & $\frac{4.96-0}{1.88 E-1}$ & & & & & & & \\
\hline$\frac{8}{8}$ & \begin{tabular}{|c|c|}
0.0089 \\
0.29
\end{tabular} & $\begin{array}{l}8.95 E-05 \\
285-02 \\
385\end{array}$ & $\begin{array}{l}0.00888 \\
0.2637\end{array}$ & $2.43 E-04$ & & \begin{tabular}{|l|l|}
$2.00 E-03$ \\
$5752-11$
\end{tabular} & & \begin{tabular}{|l|l|}
$6.699-0$ \\
2.6750
\end{tabular} & & \begin{tabular}{|l}
$6.695-03$ \\
2670.01 \\
\end{tabular} & & $\begin{array}{r}1.996-03 \\
5.965 .11\end{array}$ & & & & & & & \\
\hline$\frac{c_{a}}{C d}$ & $\begin{array}{r}0.295 \\
0.00506 \\
\end{array}$ & $\frac{2.38 E-02}{5.06 E-05}$ & $\frac{0.26737}{0.00502}$ & & $\frac{0.2657}{0.00501}$ & $\begin{array}{l}\frac{5.722-11}{7.45 E-0 .} \\
\end{array}$ & & \begin{tabular}{|l}
$\frac{2.677-0}{5.00 E-0 .}$ \\
\end{tabular} & & $\begin{array}{r}2.677-01 \\
5.00 E-03 \\
\end{array}$ & & $\begin{array}{r}5.69-111 \\
7.43 E-099 \\
\end{array}$ & & & & & & & \\
\hline$\frac{\mathrm{F}}{\mathrm{Fe}}$ & $\begin{array}{r}0.222 \\
0.00188 \\
\end{array}$ & $\frac{2.4 \mathrm{AEE}-02}{\mathbf{1 . 4 8 E - 0 5}}$ & 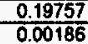 & $2.96 E-05$ & \begin{tabular}{|l|l|l}
0.19558 \\
0.00186 \\
\end{tabular} & 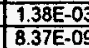 & & \begin{tabular}{|l|l|}
$\frac{1.96 E-0}{10.86-0.0}$ \\
\end{tabular} & & $\begin{aligned} 1.96 E-01 \\
1.86 E-03 \\
\end{aligned}$ & & $\begin{array}{c}1.38 E-03 \\
8.36-09 \\
\end{array}$ & & & & & & & \\
\hline$\frac{K}{M n}$ & \begin{tabular}{|c|}
0.00465 \\
0.00012 \\
\end{tabular} & $\frac{4.65 E-05}{1.23 E-06}$ & $\begin{array}{l}0.00463 \\
0.00012 \\
0.0325\end{array}$ & & \begin{tabular}{|l|}
0.00461 \\
0.0001212 \\
\end{tabular} & & & \begin{tabular}{|l|}
$4.61 E-0$ \\
$1.222-0.0$ \\
$.22 E-0$
\end{tabular} & & $\begin{array}{r}4.50 E-03 \\
1.22 E-04 \\
.320 \\
\end{array}$ & & & & & & & & & \\
\hline$\frac{\mathrm{Na}}{\mathrm{NO}}$ & \begin{tabular}{|c|}
0.021 \\
0.04
\end{tabular} & $2.10 E-04$ & $\frac{0.02082}{3.1509}$ & $\begin{array}{c}9.10 E-03 \\
23064 \\
\end{array}$ & \begin{tabular}{|l}
0.02074 \\
3.1592 \\
\end{tabular} & 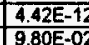 & $\frac{1.85 E-03}{5.006-03}$ & 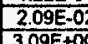 & 2066-I & $\begin{aligned} 2.09 E-02 \\
3 \\
309 E+00\end{aligned}$ & & $\frac{4.41 E-1}{3.05 E-0}$ & & & $2.96 E-0$ & $2.96 E-02$ & & & \\
\hline$\frac{104}{\mathrm{PO} 4}$ & \begin{tabular}{|l|}
0.000999 \\
\end{tabular} & 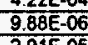 & $\begin{array}{l}\frac{0.000098}{0.00098} \\
0.0389\end{array}$ & & $\frac{5 . .0058}{0.00098}$ & 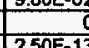 & & 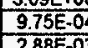 & 2.000 & 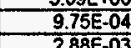 & & $\begin{array}{r}-0 \\
\end{array}$ & & & & & & & \\
\hline$\frac{504}{27}$ & \begin{tabular}{|l}
0.146 \\
0.003
\end{tabular} & $\frac{9140.03}{1.46 E-03}$ & $\frac{.0 .289}{0.14515}$ & & $\begin{array}{l}0.0 .269 \\
0.14139 \\
\end{array}$ & \begin{tabular}{|l|l|}
$\frac{2.301}{3.31 E-03}$ \\
\end{tabular} & & \begin{tabular}{|l}
$2.808-6$ \\
$1.42 E-0$ \\
\end{tabular} & & $\begin{array}{r}2.806-03 \\
1.42 E-01 \\
\end{array}$ & & $\begin{array}{l}2.4515-13 \\
3.315-03 \\
\end{array}$ & & & & & & & \\
\hline 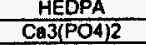 & & & & & & & & & & & & & & $1.59 E-0$ & & $1.59 E-03$ & & & $4.21 E-02$ \\
\hline$\frac{\mathrm{CaA}_{2}}{\mathrm{CaO}}$ & & & & & & & & & & & & & & \begin{tabular}{|l|l}
$2.596-0$ \\
$1.87-0$ \\
\end{tabular} & & 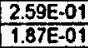 & & & $1.11 E-10$ \\
\hline$\frac{\mathrm{NaF}}{\mathrm{K} \text { KaSO4 }}$ & & & & & & & & & & & & & & \begin{tabular}{|l|l|}
$3.52 E-0$ \\
$4.01 E-0.0$
\end{tabular} & & 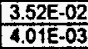 & -5 & & $\begin{array}{l}3.14 E-12 \\
\end{array}$ \\
\hline$\frac{\mathrm{A} 203}{\mathrm{~B}^{203}}$ & & & & & & & & & & & & & & \begin{tabular}{|l}
$1.67 \mathrm{E}=0$ \\
$9.50 \mathrm{E}-0.0$
\end{tabular} & & \begin{tabular}{|l|l|}
$1.67 E-01$ \\
$.905 E-02$
\end{tabular} & \begin{tabular}{|c|}
$9.96 E-03$ \\
\end{tabular} & & $\begin{array}{l}\frac{3.55 E-11}{1.42 E-02} \\
125\end{array}$ \\
\hline$\frac{2 \mathrm{rO} 2}{6 \mathrm{rom}}$ & & & & & & & & & & & & & & $\begin{array}{l}1.91 E-0 \\
\end{array}$ & & $\begin{array}{l}\frac{1.91 E-01}{266 E-03} \\
265\end{array}$ & & & \begin{tabular}{|l}
$4.47 E-03$ \\
$120 E-08$ \\
\end{tabular} \\
\hline $\mathrm{Na} 2 \mathrm{O}$ & & & & & & & & & & & & & & \begin{tabular}{|l|l|}
$.0006-0$ \\
$4.06-0$
\end{tabular} & & $\frac{4.06-02}{4.0650 .02}$ & $2.85 E-02$ & & $\begin{array}{l}2.856-.02 \\
2.85 E\end{array}$ \\
\hline 5102 & & & & & & & & & & & & & & & & & 1.04E-01 & & $1.04 E-01$ \\
\hline$\frac{\text { Cement }}{\text { FyAsh }}$ & & & & & & & & & & & & & & & $\frac{8.67 E-0}{4.34 E-0}$ & $\frac{8.67 E-01}{4.34 E-01}$ & & & \\
\hline$\frac{\text { Clay }}{\text { Sand }}$ & & & & & & & & & & & & & & & $\frac{2.96-0}{6.98 E-0}$ & 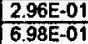 & & & \\
\hline Nux & & & & & & & & & & & & & 3.1 & & & & & 0. & \\
\hline H2O Rear & & & & & & & & & & & & & & & 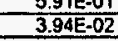 & 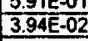 & & & \\
\hline $\begin{array}{l}\text { Actindides (ilm } 3 \text { ) } \\
\text { Am }\end{array}$ & $3.94 \mathrm{E}$ & & $823 \mathrm{E}-0.8$ & & & $8.23 \mathrm{E}-08$ & & $\begin{array}{l}1.15 E-11 \\
0.05-1\end{array}$ & & & & $\begin{array}{r}8.236-08 \\
.1860\end{array}$ & & 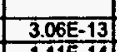 & & $\frac{4.39 E-13}{.105 .14}$ & & & $8.23 E-08$ \\
\hline$\frac{\mathrm{Cm}}{\frac{\mathrm{Np}}{\mathrm{P}_{m}}}$ & 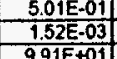 & $\frac{\frac{1.77 E-11}{\frac{1.35 E-08}{5}}}{5.25 E-082}$ & $\frac{1.76 E-09}{\frac{1.34 E-06}{5.39 E-06}}$ & $\begin{array}{c}2.00 E-15 \\
4.58 E-14 \\
928 E-14\end{array}$ & $\begin{array}{l}8.81 E-15 \\
6.74 E-07 \\
8.1 E-15\end{array}$ & \begin{tabular}{|l}
$\frac{1.76 E-09}{6.61 E-07}$ \\
$5.396-06$
\end{tabular} & & 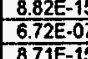 & & $\begin{array}{r}8.82 z-15 \\
6.725-07 \\
87515-15\end{array}$ & & $\begin{array}{r}1.76-0.09 \\
6.61 E-07 \\
5.39 E-07\end{array}$ & - & 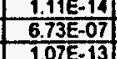 & & 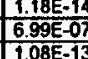 & & & $\frac{\frac{1.76 E-09}{6.61 E .07}}{5.39 E-06}$ \\
\hline $\mathrm{U}$ & \begin{tabular}{|c|}
$5.24 E-06$ \\
\end{tabular} & $\begin{array}{l}\frac{2.465-50}{2.65 E-09} \\
\end{array}$ & $2.65 E-07$ & $3.26 E-10$ & $4.16 \mathrm{E}-16$ & \begin{tabular}{|l|l|}
$2.655-07$ \\
\end{tabular} & & \begin{tabular}{|l|}
$0.15 E-1$ \\
$.15 E-1$
\end{tabular} & & $\frac{1.15 E-16}{4.15}$ & & $2.63 E_{-}-0$ & & . & & $5.65 E-10$ & & & $2.63 E-07$ \\
\hline $\begin{array}{l}\text { Fisson Prdects } \\
\mathrm{Cs}\end{array}$ & $4.20 \mathrm{E}+03$ & $3.03 E-07$ & $3.65 E-05$ & & $3.00 E-05$ & 6.41E-15 & & $3.00 E-0$ & & \begin{tabular}{|l}
$.00 E-09$ \\
\end{tabular} & 3.01E-05 & $3.01 E-05$ & & 3.02E-09 & & 1.27E-09 & & & $3.01 E-05$ \\
\hline$\frac{\operatorname{Cs}-137(\mathrm{Ci} / \mathrm{m} 3)}{\mathrm{Sr}}$ & $|3.70 E+03|$ & $1.69 \mathrm{E}-07$ & $1.68 \mathrm{E}-05$ & & $1.68 E-05$ & $\overline{3.57 E-16}$ & & $1.32 E-1$ & $19.67 E-05$ & $1.32 E-11$ & & $1.68 \mathrm{E}-05$ & & $1.32 E-11$ & & $2.13 E-10$ & & & $1.68 \mathrm{E}-05$ \\
\hline$\frac{5 r-90\left(\mathrm{Cim} \mathrm{m}^{3}\right)}{\mathrm{s}}$ & $9.55 E-03$ & $352 E-09$ & 3 49E-07 & $06 E_{-0}$ & $323 E-0$ & $14765-00$ & & $255 E-1$ & $323 E-07$ & $255 E-13$ & & $330 E-07$ & & $2055-08$ & & $121 E=08$ & & & $30 \mathrm{E}-07$ \\
\hline & & & & & $0.20 e-c$ & & & & & & & & & & & & & & \\
\hline $\begin{array}{l}\text { Vohme,m3 } \\
\text { Total mass. }\end{array}$ & $\frac{6.25 E-04}{0.838}$ & 0.056 & $\frac{1.02 E-02}{3.880}$ & $\frac{1.20 E-03}{2.316}$ & $\frac{1.14 E-02}{3.880}$ & \begin{tabular}{|l|}
$5.10 E-03$ \\
0.148
\end{tabular} & $\begin{array}{r}\frac{2.60 E-03}{0.007} \\
\end{array}$ & \begin{tabular}{|c|}
$\frac{1.44 E-02}{3.85}$ \\
\end{tabular} & \begin{tabular}{|c|}
$\frac{1.28 E-02}{0.210}$ \\
\end{tabular} & $\frac{1.44 E-02}{3.859}$ & $\frac{3.00 E-06}{0.003}$ & $\frac{8.20 E-04}{0.359}$ & 3.103 & 0.986 & & \begin{tabular}{|l|l}
$1.97 \mathrm{E}-03$ \\
3.941
\end{tabular} & \begin{tabular}{|l|}
0.142 \\
\end{tabular} & 0.305 & $\frac{7.82 E-05}{0.193}$ \\
\hline
\end{tabular}




\subsection{Processing of Sodium-Bearing Liquid Waste}

Three alternatives have been identified for processing radioactive sodium-bearing liquid waste for disposal at the ICPP. Each alternative can be implemented by more than one unit operation, and may result in one or more disposable waste forms as depicted in Figure 36.

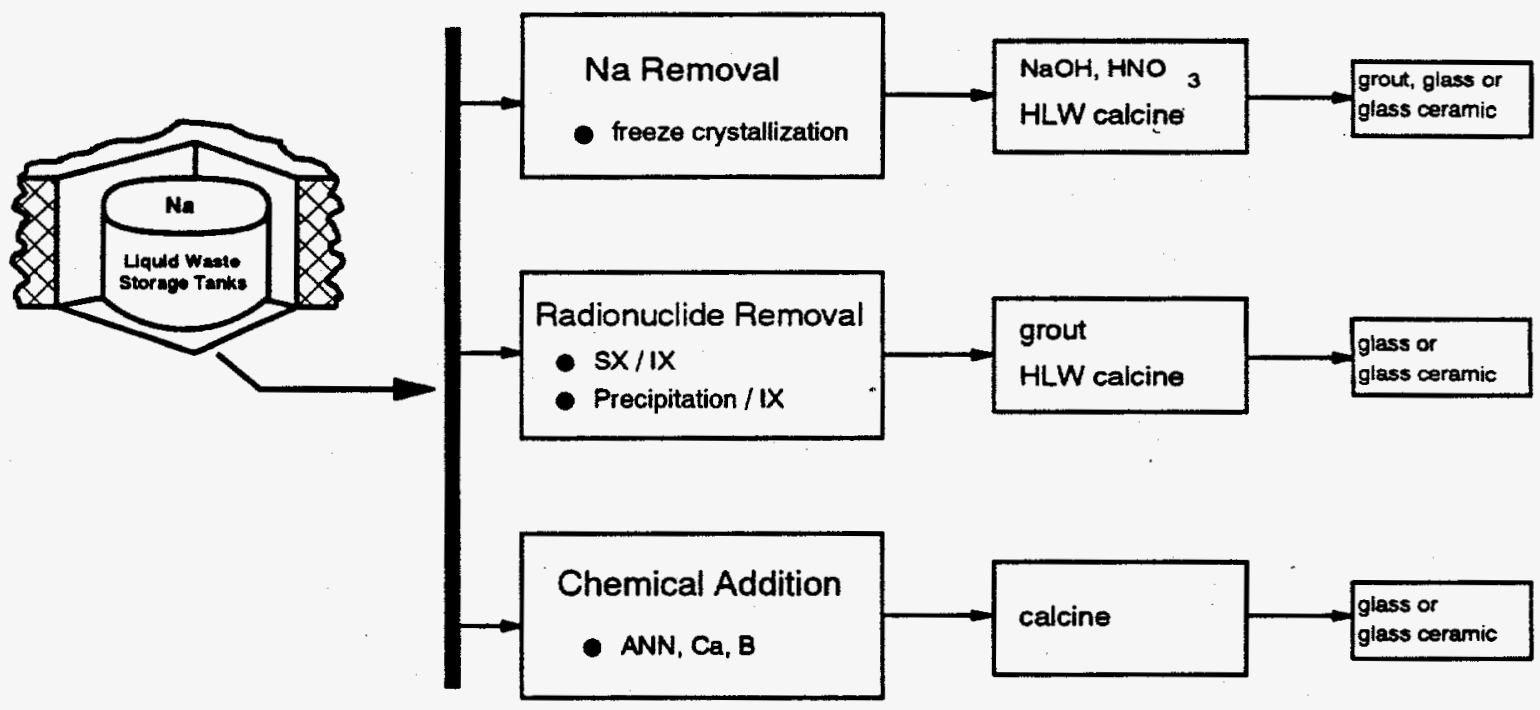

Figure 36. Sodium Waste Processing Strategies

Mass balances have been completed for four overall treatment processes which have emerged as the most likely candidates for possible implementation. These include:

1) freeze crystallization for sodium removal, calcination, and then waste immobilization;

2) actinide and fission product removal by solvent extraction and ion exchange followed by waste immobilization;

3) actinide and fission product removal by neutralization, precipitation, and ion exchange followed by waste immobilization; and

4) calcination with chemical additives followed by waste immobilization.

Calcination utilizing chemical additives is considered as the baseline case. While other process variations are possible, for instance actinide removal could be replaced by precipitation, or LLW can be either grouted or calcined, the information provided within this report provides a basis for comparison of these basic strategies. 


\subsubsection{Calcination Utilizing Chemical Additives}

This alternative can process the sodium bearing waste in the existing NWCF utilizing chemical additives and immobilize the calcine product in a glass-ceramic waste form as depicted in Figure 37.

A mass balance calculated from the sodium-bearing feed listed in Table 10 is tabulated in Table 37.

Liquid waste which contains a large concentration of sodium and potassium is difficult to calcine because the melting temperature of nitrate compounds of these elements is near the operating temperature of the fluidized bed calciner vessel. Consequently, the bed tends to agglomerate when significant quantities of these elements are contained in the feed material. To alleviate this problem non-radioactive aluminum nitrate solution is added to reduce the mole percent of these elements in the calcine. Something less than 11.4 mole percent sodium plus potassium has been shown to operate satisfactorily in pilot plant tests. Calcium nitrate is added to complex fluoride and prevents it from volatilizing and being carried out with the off-gas. Boron in the form of boric acid is added to help form non-crystalline alumina $\left(\mathrm{Al}_{2} \mathrm{O}_{3}\right)$.

Crystalline alumina, liquid waste can be retrieved from the tank farm, blended with the nonradioactive chemicals, and fed to the calciner vessel. Calcine, which is formed, is transported to the solids storage bin sets for interim storage. The calcine is then blended with glass forming frit material and immobilized into a glass-ceramic waste form in the yet-to-be-constructed hot isostatic press (HIP) mechanism. Off-gases can be filtered and discharged through the existing ICPP stack.

This alternative is considered the baseline case. With the exception of developing and constructing a glass-ceramic waste form processing facility, this alternative is the most mature and requires the least amount of development time. Flowsheets which produce calcine containing higher quantities of sodium and potassium must be verified, otherwise the process has operated for many years at ICPP. In any case, a final waste form processing facility must be developed and constructed. 

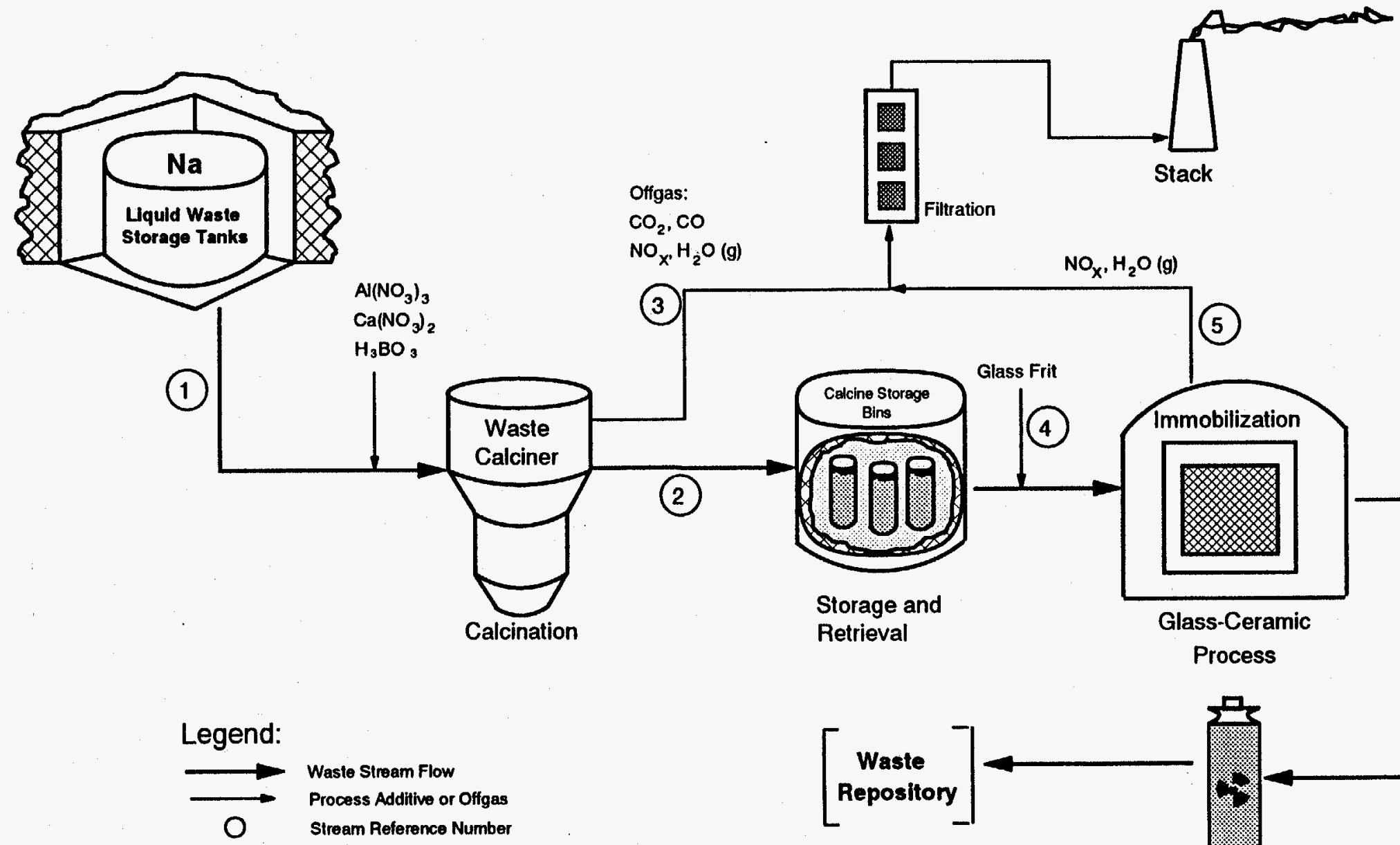

Figure 37. Baseline Sodium Waste Processing Flowsheet 
Table 37. Mass Balance for Baseline Calcination of SBW

\begin{tabular}{|c|c|c|c|c|c|c|}
\hline Component & $\begin{array}{c}1 \\
\text { Tank Waste } \\
\text { Feed } \\
\end{array}$ & $\begin{array}{c}2 \\
\text { Calcine } \\
\text { Product }\end{array}$ & $\begin{array}{c}3 \\
\text { Calcine } \\
\text { Off-Gas }\end{array}$ & $\begin{array}{c}4 \\
\text { Glass } \\
\text { Frit } \\
\end{array}$ & $\begin{array}{c}5 \\
\text { Stabilization } \\
\text { Off-Gas }\end{array}$ & $\begin{array}{c}6 \\
\text { HAW } \\
\text { Waste }\end{array}$ \\
\hline $\mathrm{H}+$ & 1.58 & & & & & \\
\hline $\mathrm{Na}$ & 43.61 & & & & & \\
\hline $\mathrm{Al}$ & 17.27 & & & & & \\
\hline $\mathrm{K}$ & 8.02 & & & & & \\
\hline $\mathrm{Ca}$ & 2.12 & & & & & \\
\hline $\mathrm{F}$ & 1.31 & & & & - & \\
\hline B & 0.19 & & & & & \\
\hline \multicolumn{7}{|l|}{$\mathrm{Fe}$} \\
\hline $\mathrm{Zr}$ & 0.18 & & & & & \\
\hline $\mathrm{Cl}$ & 1.03 & & & & & \\
\hline NO3 & 345.49 & & & & & \\
\hline $\mathrm{SO} 4$ & 4.80 & & & & & \\
\hline $\mathrm{PO} 4$ & 1.80 & & & & & \\
\hline UDS & 2.49 & 2.49 & & & & 2.49 \\
\hline $\mathrm{H} 2 \mathrm{O}$ & 767.45 & & 2545.89 & & & \\
\hline $\mathrm{NaNO} 3$ & & 98.35 & & & & \\
\hline $\mathrm{KNO3}$ & & 12.64 & & & & \\
\hline $\mathrm{Ca} 3(\mathrm{PO} 4) 2$ & & 2.95 & & & & 2.95 \\
\hline $\mathrm{CaF} 2$ & & 1.91 & & & & 1.91 \\
\hline $\mathrm{NaF}$ & & 0.84 & & & & 0.84 \\
\hline $\mathrm{K} 2 \mathrm{SO} 4$ & & 6.97 & & & & 6.97 \\
\hline $\mathrm{Na} 2 \mathrm{SO} 4$ & & 1.42 & & & & 1.42 \\
\hline $\mathrm{NaCl}$ & & 1.69 & & & & 1.69 \\
\hline $\mathrm{NaAlO} 2$ & & 27.49 & & & & 27.49 \\
\hline $\mathrm{NaBO} 2$ & & 22.07 & & & & 22.07 \\
\hline $\mathrm{Al} 2 \mathrm{O} 3$ & & 319.48 & & & & 319.48 \\
\hline $\mathrm{B} 2 \mathrm{O} 3$ & & 7.70 & & & & 7.70 \\
\hline $\mathrm{ZrO2}$ & & 0.25 & & & & 0.25 \\
\hline $\mathrm{Fe} 2 \mathrm{O} 3$ & & 3.94 & & & & 3.94 \\
\hline $\mathrm{Na} 2 \mathrm{O}$ & & & & & & 35.86 \\
\hline $\mathrm{K} 2 \mathrm{O}$ & & & & & & 5.89 \\
\hline NOX & & & 1375.00 & & 79.50 & \\
\hline $\mathrm{SiO} 2$ & & & & 237.43 & & 237.43 \\
\hline Actinides & $9.22 \mathrm{e}-0.2$ & $9.22 \mathrm{e}-02$ & & & & $9.22 \mathrm{e}-02$ \\
\hline Cs-137 & $4.70 \mathrm{e}-04$ & $4.70 \mathrm{e}-04$ & & & & $4.70 \mathrm{e}-04$ \\
\hline Sr-90 & $2.84 \mathrm{e}-04$ & $2.84 \mathrm{e}-04$ & & & & $2.84 \mathrm{e}-04$ \\
\hline Tc-99 & $1.61 e-21$ & $1.45 \mathrm{e}-21$ & $1.61 \mathrm{e}-22$ & & $1.45 \mathrm{e}-22$ & $1.30 e-21$ \\
\hline $1-129$ & $1.06 \mathrm{e}-02$ & $5.30 e-04$ & $1.01 \mathrm{e}-02$ & & $5.03 e-04$ & $2.65 e-05$ \\
\hline Volume, $\mathrm{m} 3$ & 1.00 & & & & & 0.23 \\
\hline Total Mass, $\mathrm{kg}$ & 1197.45 & 510.28 & 3920.90 & 237.43 & 79.50 & 678.46 \\
\hline
\end{tabular}




\subsubsection{Sodium Nitrate Removal Utilizing Freeze Crystallization}

This alternative is very similar to the baseline case discussed in Section 5.5.1. The difference is that, prior to calcination, the waste is fed to a freeze crystallization process unit where sodium nitrate and water are removed from the solution, which in turn concentrates the waste solution. The process flow diagram, is depicted in Figure 38.

The sodium-rich stream is fed to a grout facility where NRC Class C, or better, qualified waste containers are produced. The stream which is more concentrated in radionuclides is routed to the NWCF for calcination, and then to the glass-ceramic processing facility for final waste immobilization. Table 38 provides the mass balance.

Freeze crystallization is a well established industrial technology in the chemical processing industries; food processing is one of the most frequent users of this technology. However, at this point in time, we have only literature information and limited laboratory-scale data concerning its performance in nuclear waste stream processing. Its maturity level is relatively low and considerable process chemistry data is required to determine separation factors. Additionally, standard industrial equipment will require unknown levels of development and modification to be considered operable in a nuclear waste processing environment. 


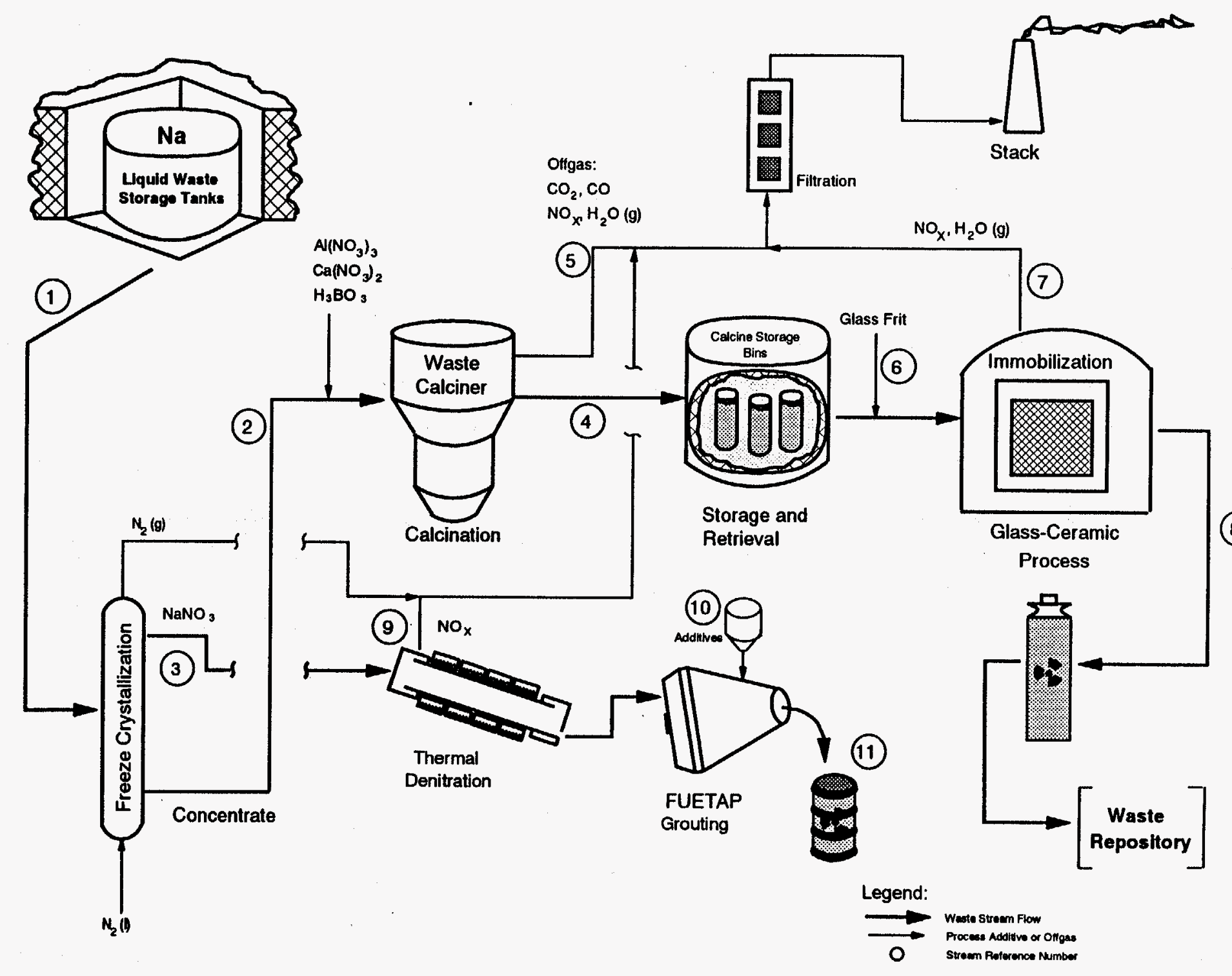

Figure 38. Flowsheet for Sodium Waste Processing using Freeze Crystallization 
Table 38. Mass Balance for Sodium Nitrate Removal Utilizing Freeze Crystallization

\begin{tabular}{|c|c|c|c|c|c|c|c|c|c|c|c|}
\hline Component & $\begin{array}{c}1 \\
\text { Tank Waste } \\
\text { Feed }\end{array}$ & $\begin{array}{c}2 \\
\text { Waste to } \\
\text { Calcination }\end{array}$ & $\begin{array}{c}3 \\
\text { NaNO3 } \\
\text { Stream }\end{array}$ & $\begin{array}{c}4 \\
\text { Calcine } \\
\text { Product }\end{array}$ & $\begin{array}{c}5 \\
\text { Calcine } \\
\text { Off-Gas }\end{array}$ & $\begin{array}{c}6 \\
\text { Glass } \\
\text { Frit }\end{array}$ & $\begin{array}{c}7 \\
\text { Stabilization } \\
\text { Oft-Gas }\end{array}$ & $\begin{array}{c}8 \\
\text { HAW } \\
\text { Waste }\end{array}$ & $\begin{array}{c}9 \\
\text { NOx } \\
\text { Off-Gas }\end{array}$ & $\begin{array}{c}10 \\
\text { Grout } \\
\text { Additives }\end{array}$ & $\begin{array}{l}11 \\
\text { LLW } \\
\text { Grout }\end{array}$ \\
\hline $\mathrm{Hi}$ & 1.578 & 1.546 & 0.032 & & & & & & & & \\
\hline $\mathrm{Na}$ & 43.612 & 15.700 & 27.912 & & & & & & & & \\
\hline$K$ & 8.016 & 7.856 & 0.160 & & & & & & & & \\
\hline$B$ & 0.195 & 0.191 & 0.004 & & & & & & & & \\
\hline Al & 17.268 & 16.923 & 0.345 & & & & & & & & \\
\hline $\mathbf{Z r}$ & 0.182 & 0.179 & 0.004 & & & & & & & & \\
\hline $\mathrm{Ca}$ & 2.124 & 2.082 & 0.042 & & & & & & & & \\
\hline $\mathrm{Fe}$ & 2.753 & 2.711 & 0.042 & & & & & & & & \\
\hline$F$ & 1.311 & 1.285 & 0.026 & & & & & $=$ & & & \\
\hline CI & 1.028 & 1.008 & 0.021 & & & & & & & & \\
\hline $\mathrm{NO} 3$ & 345.486 & 265.691 & 79.794 & & & & & & & 7.381 & 7.381 \\
\hline 504 & 4.803 & 4.707 & 0.096 & & & & & & & & \\
\hline PO4 & 1.804 & 1.768 & 0.036 & & & & & & & & \\
\hline UDS & 2.488 & 2.488 & 0.000 & 2.488 & & & & 2.488 & & & \\
\hline $\mathrm{H} 2 \mathrm{O}$ & 767.456 & 176.515 & 590.941 & & & & & & & 147.621 & 147.621 \\
\hline NaNO3 & & & & 35.407 & & & & & & & \\
\hline $\mathrm{KNO}$ & & & & 12.391 & & & & & & & \\
\hline $\mathrm{Ca} 3(\mathrm{PO} 4)^{2}$ & & & & 2.888 & & & & 2.888 & & & 0.059 \\
\hline $\mathrm{CaF2}$ & & & & 1.875 & & & & 1.875 & & & 0.038 \\
\hline $\mathrm{CaO}$ & & & & 0.000 & & & & & & & \\
\hline NaF & & & & 0.823 & & & & 0.823 & & & 0.017 \\
\hline $\mathrm{K} 2504$ & & & & 6.827 & & & & 6.827 & & & 0.139 \\
\hline $\mathrm{Na2SO4}$ & & & & 1.395 & & & & 1.395 & & & 0.028 \\
\hline $\mathrm{KCl}$ & & & & 0.000 & & & & & & & \\
\hline $\mathrm{NaCl}$ & & & & 1.661 & & & & 1.661 & & & 0.034 \\
\hline $\mathrm{NaAlO} 2$ & & & & 8.142 & & & & 8.142 & & & 19.349 \\
\hline $\mathrm{NaBO} 2$ & & & & 6.536 & & & & 6.536 & & & 15.532 \\
\hline $\mathrm{Al2O3}$ & & & & 135.703 & & & & 124.488 & & & 184.894 \\
\hline $\mathrm{B2O3}$ & & & & 3.494 & & 51.210 & & 54.182 & & & 2.807 \\
\hline $\mathrm{ZrO2}$ & & & & 0.242 & & & & 0.242 & & & 0.005 \\
\hline $\mathrm{Fe} 203$ & & & & 3.876 & & & & 3.876 & & & $0 . \overline{061}$ \\
\hline $\mathrm{Na2O}$ & & & & & & & & 12.910 & & & 22.950 \\
\hline $\mathrm{K} 2 \mathrm{O}$ & & & & & & & & 5.772 & & & 0.118 \\
\hline NOX & & & & & 629.218 & & 33.429 & & 46.075 & & \\
\hline $\mathrm{H} 2 \mathrm{O}$ & & & & & 1024.594 & & & & & & \\
\hline $\mathrm{SiO} 2$ & & & & & & 375.542 & & 375.542 & & & \\
\hline Cement & & & & & & & & & & 216.510 & 216.510 \\
\hline Fly Ash & & & & & & & & & & 108.255 & 108.255 \\
\hline Clay & & & & & & & & & & 73.810 & 73.810 \\
\hline Sand & & & & & & & & & & 174.684 & 174.684 \\
\hline H2O Reducer & & & & & & & & & & 9.841 & 9.841 \\
\hline Actinides & 9.22E-02 & $9.04 E-02$ & $1.84 E-03$ & $9.04 \mathrm{E}-02$ & & & & & & & $1.84 E-03$ \\
\hline Cs-137 & $4.70 E-04$ & $4.61 \mathrm{E}-04$ & $9.40 E-06$ & $4.61 E-04$ & & & & & & & 9.40E-06 \\
\hline $\mathrm{Sr}-90$ & 2.84 E-04 & 2.78E-04 & 5.67E-06 & $2.78 \mathrm{E}-04$ & & & & & & & $5.67 E-06$ \\
\hline Tc-99 & 1.61E-21 & 1.57E-21 & $3.21 E-23$ & $1.42 \mathrm{E}-21$ & $1.57 \mathrm{E}-22$ & & $1.28 \mathrm{E}-21$ & $1.42 \mathrm{E}-22$ & $3.21 E-24$ & & $2.89 E-23$ \\
\hline $1-129$ & $1.06 \mathrm{E}-02$ & 1.04E-02 & 2.12E-04 & $5.19 \bar{E}-04$ & $9.86 E-03$ & & $2.60 E-05$ & $4.93 E-04$ & 2.01E-04 & & 1.06E-05 \\
\hline Volume, m3 & 1.000 & & & & & & & 0.241 & & & 0.305 \\
\hline Total Mass, $\mathrm{kg}$ & 1200.21 & 500.75 & 699.46 & 223.84 & 1653.82 & 426.75 & 33.43 & 609.65 & 46.08 & 738.70 & 984.14 \\
\hline
\end{tabular}




\subsubsection{Radionuclide Removal Utilizing Neutralization and Precipitation}

Near quantitative removal of metal hydroxides from the sodium-bearing waste can be achieved by adding sodium hydroxide until the solution $\mathrm{pH}$ is about 13. A process flow diagram for this alternative is depicted in Figure 39. Sodium-bearing waste is combined with sodium hydroxide to precipitate the metals as a sludge. The liquid and the sludge are separated and the liquid is transferred to a fixed adsorption bed for cesium removal. Cesium, sodium, and potassium do not precipitate at high $\mathrm{pH}$ levels. Liquid which has had the metals and radionuclides removed is then fed to an electrohydrolysis unit where sodium hydroxide is formed and recycled back to neutralization and precipitation. Dilute waste from the electrohydrolysis unit can be considered to meet or be less than the requirements for NRC Class A low-level waste, and can be fed to a grout process for immobilization. Sludge from the precipitation process and spent resin from Cs removal can be combined and fed to a calcination unit to drive off water. This product can then be fed to a glass melter for vitrification. The resulting waste form is then suitable for long-term disposal in a federal repository.

A mass balance calculated from the sodium bearing feed listed in Table 10 is tabulated in Table 39.

Neutralization and precipitation are similar to a technology which has been operational for many years at other DOE sites, including Hanford and Savannah River. Vitrification technology has been implemented full-scale in Europe, and Savannah River is about to go operational with a vitrification plant. Ion exchange and grouting are well known and established as industrial technologies. Electrohydrolysis has been implemented on an industrial scale, but requires significant development to be applied to a radioactive environment with this type of waste stream. With the exception of electrohydrolysis, these technologies can be implemented with relatively minor developmental work. 


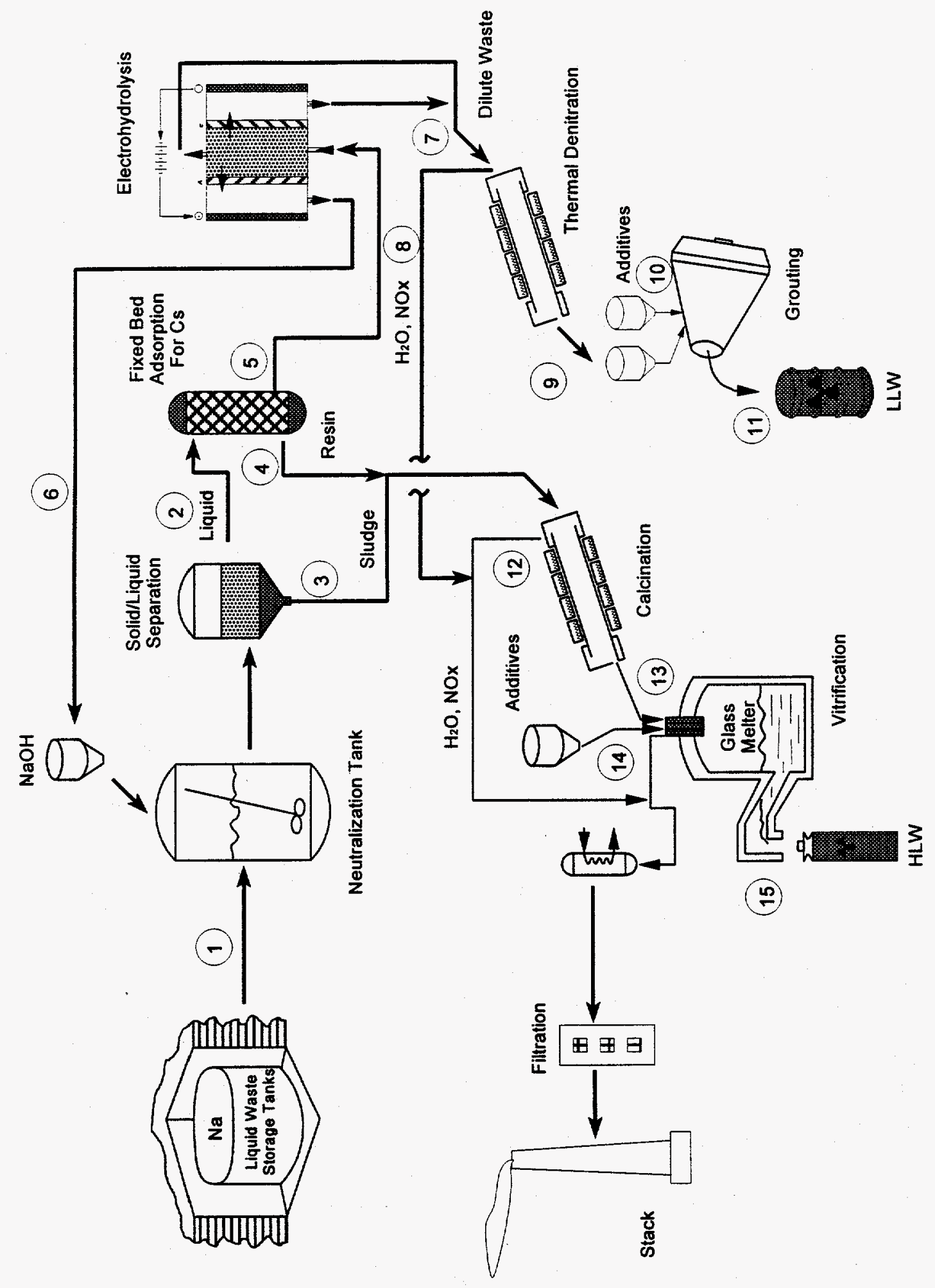

焉 
Table 39. Mass Balance for Sodium Waste Processing Utilizing Neutralization and Precipitation

\begin{tabular}{|c|c|c|c|c|c|c|c|c|c|c|c|c|c|c|c|}
\hline Component & $\begin{array}{c}1 \\
\text { Tank Waste } \\
\text { Feed }\end{array}$ & $\begin{array}{l}2 \\
\text { LLW } \\
\text { PPT }\end{array}$ & $\begin{array}{l}3 \\
\text { HAW } \\
\text { PPT }\end{array}$ & \begin{tabular}{|c|} 
\\
Ion Exchange \\
Resin
\end{tabular} & $\begin{array}{l}5 \\
\text { LLW } \\
\text { to EH }\end{array}$ & $\begin{array}{c}6 \\
\text { Recycled } \\
\mathrm{NaOH}\end{array}$ & \begin{tabular}{|c|}
7 \\
HNO3 + \\
Dilute Waste
\end{tabular} & \begin{tabular}{|c|}
8 \\
H2O, NOx \\
On-Gas
\end{tabular} & \begin{tabular}{|c|}
9 \\
Waste to \\
Grout
\end{tabular} & $\begin{array}{c}10 \\
\text { Grout } \\
\text { Additives }\end{array}$ & $\begin{array}{l}11 \\
\text { LLW } \\
\text { Grout }\end{array}$ & $\begin{array}{c}12 \\
\text { H2O, NOx } \\
\text { On-Gas }\end{array}$ & $\begin{array}{c}13 \\
\text { HLW to } \\
\text { Class }\end{array}$ & $\begin{array}{c}14 \\
\text { Glass } \\
\text { Additives }\end{array}$ & $\begin{array}{c}15 \\
\text { High Level } \\
\text { Waste Form }\end{array}$ \\
\hline $\mathrm{OH}$. & & 113.892 & & & 113.892 & 108.157 & 113.895 & & & & & & & & \\
\hline $\mathrm{H}+$ & 1.577 & 1.215 & 0.363 & & 1.215 & & 7.625 & & & & & & & $=$ & \\
\hline $\mathrm{Na}$ & 43.612 & 197.569 & & & 197.569 & 146.202 & 51.368 & & & & & & & & \\
\hline Al & 8.016 & 8.016 & & & 8.016 & 1.278 & 0.449 & & & & & & & & \\
\hline K & 0.195 & 0.019 & 0.175 & & 0.019 & 5.932 & 2.084 & & & & & & & & \\
\hline $\mathrm{Ca}$ & 17.268 & 1.727 & 15.541 & & 1.727 & 0.786 & 0.276 & & & & & & & & \\
\hline $\mathrm{F}$ & 0.182 & 0.027 & 0.155 & & 0.027 & & 1.311 & & & & & & & & \\
\hline$B$ & 2.124 & 1.062 & 1.062 & & 1.062 & 0.014 & 0.005 & & & & & & & & \\
\hline $\mathrm{Fe}$ & 2.737 & 0.274 & 2.463 & & 0.274 & 0.203 & 0.071 & & & & & & & & \\
\hline $\mathrm{Zr}$ & 1.311 & 1.311 & & & 1.311 & 0.020 & 0.007 & & & & & & & & \\
\hline Cl & 1.028 & 1.028 & & & 1.028 & & 1.028 & & & & & & & & \\
\hline NO3 & \begin{tabular}{|l|}
532.856 \\
\end{tabular} & 388.320 & 144.536 & & 388.320 & & 394.314 & & & 4.187 & 4.187 & & & & \\
\hline $\mathrm{SO} 4$ & 4.803 & 4.803 & & & 4.803 & & 4.803 & & & & & & & & \\
\hline PO4 & 1.804 & 1.804 & & & 1.804 & & 1.804 & & & & & & & & \\
\hline UDS & 2.488 & & 2.488 & & & & & & & & & & & & 2.488 \\
\hline $\mathrm{H} 2 \mathrm{O}$ & 579.895 & 579.895 & & & 579.895 & 116.333 & 348.998 & 613.669 & & 83.736 & 83.736 & 176.515 & & & \\
\hline \multirow{2}{*}{\multicolumn{16}{|c|}{$\frac{\mathrm{NaNO3}}{\mathrm{KNO3}}$}} \\
\hline & & & & & & & & & & & & & & & \\
\hline $\mathrm{Ca3}(\mathrm{PO} 4)_{2}$ & & & & & & & & & 0.712 & & 0.712 & & & & \\
\hline \multicolumn{16}{|l|}{$\mathrm{CaF2}$} \\
\hline $\mathrm{CaO}$ & & & & & & & & & & & & & 1.486 & & 1.486 \\
\hline $\mathrm{NaF}$ & & & & & & & & & 2.897 & & 2.897 & & & & 0.000 \\
\hline $\mathrm{K}_{2} \mathrm{SO}_{4}$ & & & & & & & & & 1.811 & & 1.811 & & & & \\
\hline $\mathrm{Na} 2 \mathrm{SO} 4$ & & & & & & & & & 5.626 & & 5.626 & & & & \\
\hline \multicolumn{16}{|l|}{$\mathrm{KCl}$} \\
\hline $\mathrm{NaCl}$ & & & & & & & & & 1.695 & & 1.695 & & & & \\
\hline NaAlO2 & & & & & & & & & 37.242 & & 37.242 & & & & \\
\hline $\mathrm{NaBO} 2$ & & & & & & & & & 8.432 & & 8.432 & & & & \\
\hline $\mathrm{Al}_{2} \mathrm{O} 3$ & & & & & & & & & 33.765 & & 33.765 & & 29.365 & & 29.365 \\
\hline 8203 & & & & & & & & & 0.037 & & 0.037 & & 1.887 & 14.578 & 16.465 \\
\hline ZrO2 & & & & & & & & & 0.010 & & 0.010 & & 0.209 & & 0.209 \\
\hline $\mathrm{Fe} 2 \mathrm{O3}$ & & & & & & & & & 0.102 & & 0.102 & & 3.521 & & 3.521 \\
\hline $\mathrm{Na} 2 \mathrm{O}$ & & & & & & & & & 45.700 & & 45.700 & & & & \\
\hline $\mathrm{K} 2 \mathrm{O}$ & & & & & & & & & 1.531 & & 1.531 & & & & \\
\hline NOX & & & & & & & & 598.930 & & & & 144.536 & & & \\
\hline $\mathrm{SiO} 2$ & & & & & & & & & & & & & & 76.536 & 76.536 \\
\hline AMP & & & & $9.79 \mathrm{E}-06$ & & & & & & & & & & & \\
\hline Cement & & & & & & & & & & 122.813 & 122.813 & & & & \\
\hline Fly Ash & & & & & & & & & & 61.406 & 61.406 & & & & \\
\hline Clay & & & & & & & & & & 41.868 & 41.868 & & & & \\
\hline Sand & & & & & & & & & & 99.088 & 99.088 & & & & \\
\hline H2O Reducer & & & & & & & & & & 5.582 & 5.582 & & & & \\
\hline Actinides & \begin{tabular}{|c|}
$9.22 \mathrm{E}-02$ \\
\end{tabular} & $0.00 E+00$ & $9.22 E-02$ & & $0.00 E+00$ & $0.00 E+00$ & $0.00 E+00$ & & $0.00 E+00$ & & $0.00 \mathrm{E}+00$ & & & & $9.22 E-02$ \\
\hline Cs-137 & $4.70 E-04$ & $4.70 E-04$ & $0.00 \mathrm{E}+00$ & $4.70 \mathrm{E}-04$ & $0.00 E+00$ & $0.00 E+00$ & $0.00 E+00$ & & $0.00 E+00$ & & $0.00 \mathrm{E}+00$ & & & & $4.70 \mathrm{E}-04$ \\
\hline $\mathrm{Sr}-90$ & $2.84 \mathrm{E}-04$ & $1.51 \mathrm{E}-04$ & $1.33 \mathrm{E}-04$ & & $1.51 E-04$ & $1.17 \mathrm{E}-04$ & $3.31 \mathrm{E}-05$ & & $3.31 \mathrm{E}-05$ & & $3.31 \mathrm{E}-05$ & & & & $1.33 E-04$ \\
\hline TC-99 & $0.00 E+00$ & $0.00 E+00$ & $0.00 \mathrm{E}+00$ & & $0.00 E+00$ & $0.00 \mathrm{E}+00$ & $0.00 E+00$ & & $0.00 E+00$ & & $0.00 E+00$ & & & & $0.00 E+00$ \\
\hline $1-129$ & $1.06 E-02$ & $1.06 \mathrm{E}-02$ & $0.00 E+00$ & & $1.06 E-02$ & $0.00 E+00$ & $1.06 E .02$ & $1.01 E-02$ & $5.30 \mathrm{E}-04$ & & $5.30 E-04$ & & & & $0.00 E+00$ \\
\hline Volume, $\mathrm{m}^{3}$ & & & & & & & & & & & 0.28 & & & & 0.052 \\
\hline Total Mass, kg & 1200.0 & 1301.0 & 166.9 & 0.00048 & 9301.0 & 378.9 & 928.0 & 1212.6 & 139.6 & 418.7 & 558.2 & 321 & 36.5 & 91.1 & 130.2 \\
\hline
\end{tabular}




\subsubsection{Radionuclide Removal by Solvent Extraction and Ion Exchange}

An alternative has been developed for the separation of actinides, $\mathrm{Sr}, \mathrm{Cs}$, and $\mathrm{Tc}$ from sodiumbearing waste utilizing solvent extraction and ion exchange technologies. A process flow diagram is depicted in Figure 40, and the associated material balance is listed in Table 40. This flowsheet is based on the processing of waste material listed in Table 10.

Actinides are extracted from the dissolved calcine using the TRUEX Process. Sr and Tc are extracted from the dissolved calcine using the SREX Process. Cs is then removed from the dissolved calcine by ion exchange. Pending calcine characterization, heavy metal removal may also be necessary. The resulting raffinate (low-level waste) is denitrated and grouted for nearsurface disposal. The actinides can be converted to a waste form for engineered storage or burned within the Integral Fast Reactor (IFR). The Cs loaded ion exchange resin, $\mathrm{Sr}$, and $\mathrm{Tc}$ are converted to a waste form for engineered storage and eventual reuse. The cesium loaded, ion exchange resin, and the $\mathrm{Sr}$, and $\mathrm{Tc}$, are immobilized in a waste form for repository disposal. The flowsheet presented in Figure 40 is based on combining the actinides, $\mathrm{Sr}, \mathrm{Cs}$, and undissolved calcine for high-level waste immobilization. Modifications to the material balance will be necessary if the actinides would be burned in the IFR or separate engineered storage is needed.

The main advantage of this process is the reduction in quantity of high-level waste requiring disposal in a repository. The existing flowsheet for converting calcine directly to a glass ceramic waste form results in 0.44 liters of waste form per $\mathrm{kg}$ of calcine processed ( $70 \%$ solids loading). The aqueous separations flowsheet results in 0.13 liters of waste form per $\mathrm{kg}$ of calcine processed. This is a $70 \%$ reduction in high-level waste volume, which could significantly reduce the repository costs. Another advantage of this process is that a similar flowsheet can be used for the processing of sodium waste or dissolved fuel.

A potential disadvantage of this process is the low-level waste which is generated.

Approximately 1.1 liters of low-level waste grout is generated for each $\mathrm{kg}(0.7$ liters $)$ of calcine processed. In addition, liquid waste will be generated which will require disposal to the PEW evaporator. 


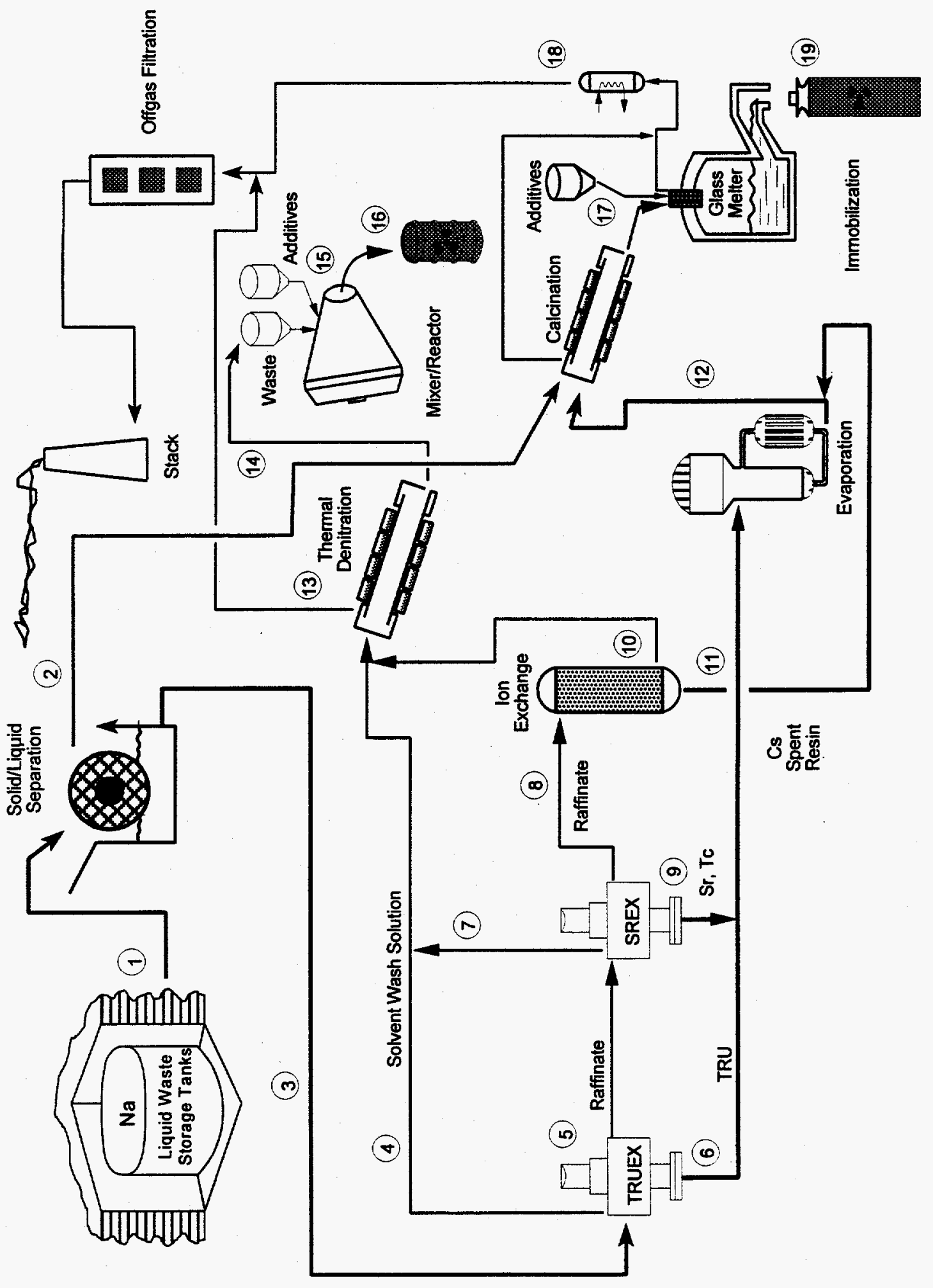

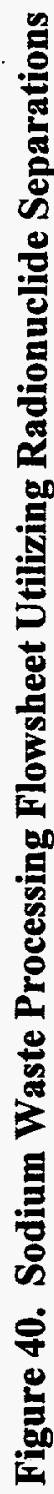


Table 40. Mass Balance for Sodium Waste Processing Utilizing Radionuclide Separations

\begin{tabular}{|c|c|c|c|c|c|c|c|c|c|c|c|c|c|c|c|c|c|c|c|}
\hline Component & $\begin{array}{c}1 \\
\text { Sodium } \\
\text { Wasto }\end{array}$ & $\begin{array}{l}2 \\
\text { Sollid } \\
\text { Wasto }\end{array}$ & \begin{tabular}{|c|}
3 \\
Liquidd \\
Wasto
\end{tabular} & \begin{tabular}{|c|}
$\begin{array}{c}4 \\
\text { Solvent } \\
\text { Wash Soln }\end{array}$ \\
\end{tabular} & \begin{tabular}{|c|}
5 \\
TRUEX \\
Ralfinatio
\end{tabular} & \begin{tabular}{|c|}
6 \\
TRUEX \\
Product
\end{tabular} & \begin{tabular}{|c|}
7 \\
SREX Sovont \\
Wash Soln
\end{tabular} & $\begin{array}{c} \\
\text { SREX } \\
\text { Raffinale } \\
\end{array}$ & $\begin{array}{c}9 \\
\text { SREX } \\
\text { Product } \\
\end{array}$ & \begin{tabular}{|c|}
10 \\
Ion Exchange \\
Product
\end{tabular} & \begin{tabular}{|c|}
11 \\
Ion Exchange \\
Resin
\end{tabular} & $\begin{array}{c}12 \\
\text { Concentated } \\
H L W\end{array}$ & $\begin{array}{l}13 \\
\text { LW } \\
\text { NOX } \\
\end{array}$ & $\begin{array}{c}14 \\
\text { Donitrated } \\
\text { LLW }\end{array}$ & $\begin{array}{c}15 \\
\text { Grout } \\
\text { Addifives }\end{array}$ & $\begin{array}{l}16 \\
\text { LLw } \\
\text { Grout }\end{array}$ & $\begin{array}{c}17 \\
\text { Glan } \\
\text { Frill }\end{array}$ & $\begin{array}{l}18 \\
\text { HLW } \\
\text { NOX } \\
\end{array}$ & $\begin{array}{c}19 \\
\text { HLW } \\
\text { Glase }\end{array}$ \\
\hline A & $\frac{17.267}{17}$ & & 17.267 & & $\begin{array}{l}17.270 \\
\end{array}$ & 0.000 & & \begin{tabular}{|l}
17.073 \\
\end{tabular} & & 17.073 & & $3.32 E-09$ & & & & & & & \\
\hline 8 & 0.195 & & 0.195 & & 0.195 & 0.000 & & 0.192 & & 0.192 & & $4.58 E-06$ & & & & & & & \\
\hline Ba & 0.084 & & 0.084 & & 0.008 & 0.000 & & 0.008 & & 0.008 & & 1.62E-12 & & & & & & & \\
\hline $\mathrm{Ca}$ & 2.124 & & 2.124 & & 2.124 & 0.000 & & \begin{tabular}{|l}
2.099 \\
\end{tabular} & & 2.099 & & $4.09 E-10$ & & & & & & & \\
\hline Cd & 0.315 & & 0.315 & & 0.315 & 0.000 & & 0.312 & & 0.312 & & $2.09 \mathrm{E}-10$ & & & & & & & \\
\hline $\mathrm{Cl}$ & 1.028 & & 1.028 & & 1.028 & 0.000 & & 1.018 & & 1.018 & & $0.00 E+00$ & & & & & & & \\
\hline$F$ & 1.311 & & 1.311 & & 1.311 & 0.044 & & 1.295 & & 1.295 & & $3.93 \mathrm{E}-02$ & & & & & & & \\
\hline $\mathrm{Fe}$ & 2.542 & & 2.542 & & 2.542 & 0.000 & & 2.510 & & 2.510 & & $4.28 \mathrm{E}-09$ & & & & & & & \\
\hline $\mathrm{H}+$ & 1.578 & & 1.578 & & 1.472 & 0.077 & 0.009 & 1.454 & 0.181 & 1.454 & & $2.42 \mathrm{E}-01$ & & & & & & & \\
\hline $\mathrm{Hg}$ & 0.221 & & 0.221 & 0.219 & 0.002 & 0.002 & & 0.002 & & 0.002 & & $2.01 E-03$ & & & & & & & \\
\hline $\mathrm{k}$ & 8.016 & & 8.016 & & 8.015 & 0.000 & & 7.937 & & 7.937 & & $0.00 E+00$ & & & & & & & \\
\hline $\mathrm{Na}$ & 43.612 & & 43.612 & 2.644 & 43.606 & 0.000 & 2.276 & 43.129 & & 43.129 & & $8.40 \mathrm{E}-09$ & & & & & & & \\
\hline $\mathrm{NO3}$ & 315.580 & & 315.580 & & 313.317 & 4.712 & 0.577 & 310.744 & 11.160 & 310.744 & & $1.49 E+01$ & & & & & & & \\
\hline 504 & 4.803 & & 4.803 & & 4.803 & 0.000 & & 4.747 & & 4.747 & & $3.75 E-10$ & & & & & & & \\
\hline $2 r$ & 0.182 & & 0.182 & & 0.091 & 0.090 & & 0.090 & & 0.090 & & $8.06 E-02$ & & & & & & & \\
\hline $\mathrm{Ca} 3\left(\mathrm{PO}^{4}\right) 2$ & & & & & & & & & & & & & & & & & & & $7.96 \mathrm{E}-10$ \\
\hline$\frac{\mathrm{CaF} 2}{\mathrm{CaO}}$ & & & & & & & & & & & & & & $\frac{0.109}{0.078}$ & & $\begin{array}{l}0.109 \\
0.078\end{array}$ & & & $7.96 \mathrm{E}-10$ \\
\hline $\mathrm{NaF}$ & & & & & & & & & & & & & & 0 & & 0 & & & $5.98 E-09$ \\
\hline K2SO4 & & & & & & & & & & & & & & 6.973 & & 6.973 & & & \\
\hline $\mathrm{Na} 2 \mathrm{SO} 4$ & & & & & & & & & & & & & & 1.414 & & 1.414 & & & \\
\hline $\mathrm{KCl}$ & & & & & & & & & & & & & & & & 可 & & & \\
\hline $\mathrm{NaCl}$ & & & & & & & & & & & & & & 1.699 & & 1.699 & & & \\
\hline $\mathrm{NaAO} 2$ & & & & & & & & & & & & & & 31.460 & & 31.460 & & & \\
\hline $\mathrm{NaBO} 2$ & & & & & & & & & & & & & & 25.254 & & 25.254 & & & \\
\hline $\mathrm{A} 2 \mathrm{O} 3$ & & & & & & & & & & & & & & 338.333 & & 338.333 & & & 11.216 \\
\hline 8203 & & & & & & & & & & & & & & 11.703 & & 11.703 & 3.740 & & 4.471 \\
\hline $\mathrm{ZrO2}$ & & & & & & & & & & & & & & 0.123 & & 0.123 & & & 0.109 \\
\hline $\mathrm{Fe} 2 \mathrm{O} 3$ & & & & & & & & & & & & & & 1.877 & & 1.877 & & & $6.13 E-09$ \\
\hline $\mathrm{Na2O}$ & & & & & & & & & & & & & & 39.580 & & 39.580 & 6.234 & & 6.234 \\
\hline $\mathrm{K} 20$ & & & & & & & & & & & & & & 5.896 & & 5.896 & & & \\
\hline NOX & & & & & & & & & & & & & 1501.325 & & & & & 55.804 & \\
\hline 02 & & & & & & & & & & & & & & & & & & & \\
\hline MEDPA & & & & & & 3.131 & & & & & & 3.131 & & & & & & & \\
\hline $\mathrm{H} 3 \mathrm{POO}$ & & & & & & & & & & & & & & & & & & & 3.131 \\
\hline UDS & 2.5 & 2.5 & & & & & & & & & & 2.5 & & & & & & & 2.5 \\
\hline $\mathrm{SiO} 2$ & & & & & & & & & & & & & & & & & 34.585 & & 31.585 \\
\hline Cement & & & & & & & & & & & & & & & 457.399 & 457.399 & & & \\
\hline FyAsh & & & & & & & & & & & & & & & 228.699 & 228.699 & & & \\
\hline Clay & & & & & & & & & & & & & & & 155.931 & 155.931 & & & \\
\hline Sand & & & & & & & & & & & & & & & 424.133 & 424.133 & & & \\
\hline $\mathrm{NO} 3$ & & & & & & & & & & & & & & & 15.593 & 15.593 & & & \\
\hline $\mathrm{H} 2 \mathrm{O}$ & & & & & & & & & & & & & & & 311.863 & 311.863 & & & \\
\hline H2O Reducer & & & & & & & & & & & & & & & 20.791 & 20.791 & & & \\
\hline Actinides & & & & & & & & & & & & & & & & & & & \\
\hline An & $3.38 E-05$ & & $3.38 E-05$ & $2.82 E-14$ & $1.13 E-12$ & $3.43 E-05$ & & $1.12 E-12$ & & $1.12 E-12$ & & $3.07 E-05$ & & 1.16E-12 & & 1.16E-12 & & & $\frac{3.32 E-05}{4.34 E-04}$ \\
\hline $\mathrm{NP}$ & $6.45 E-04$ & & $6.45 E-04$ & $7.20 \mathrm{E}-13$ & $2.05 E-04$ & $4.46 \mathrm{E}-04$ & & $2.02 E-04$ & & $2.02 E-04$ & & $4.00 \mathrm{E}-04$ & & $2.04 E-04$ & & $2.04 E-04$ & & & $\frac{4.34 E-04}{5.97 E-03}$ \\
\hline $\mathrm{Pu}$ & $6.05 E-03$ & & $6.05 \mathrm{E}-03$ & $1.85 E-07$ & \begin{tabular}{|l|}
$3.01 \mathrm{E}-12$ \\
\end{tabular} & \begin{tabular}{|l|l|}
$6.13 E-03$ \\
\end{tabular} & & $2.97 \mathrm{E}-12$ & & $2.97 E-12$ & & $5.50 E-03$ & & $\frac{1.83 E-07}{207}$ & & $\frac{1.83 E-07}{2075.18}$ & & & $\frac{5.97 E-03}{1.19 E-01}$ \\
\hline U & $1.21 E-01$ & & 1.21E-01 & $2.24 E-10$ & $5.48 E-12$ & $1.22 E-01$ & & $5.47 \mathrm{E} \cdot 12$ & & $5.43 E-12$ & & 1.09E-01 & & $2.27 E-10$ & & $2.27 E-10$ & & & 1.198 .01 \\
\hline$\frac{\text { Fisson Prdcts }}{\mathrm{Cs}}$ & $1.51 \mathrm{E}-03$ & & $7.51 E-03$ & & $1.51 \mathrm{E}-03$ & $3.24 \mathrm{E}-13$ & & $1.49 \mathrm{E}-03$ & & $1.49 E-07$ & $1.48 E-03$ & $2.90 E-13$ & & 1.51E-07 & & $1.51 E-07$ & & & $1.48 E-03$ \\
\hline Cs-137(CiM3) & $2.88 E+01$ & & & & & & & & & & & & & & & & & & \\
\hline si & $2.85 E-04$ & & $2.85 E-04$ & & $2.85 \mathrm{E}-04$ & $6.12 E-14$ & & $2.53 \mathrm{E}-09$ & & $2.53 E-09$ & & $2.59 \mathrm{E}-04$ & & $2.57 \mathrm{E}-09$ & & $2.57 \mathrm{E}-09$ & & & $2.81 E-04$ \\
\hline Sr.90(Cim 33 & $3.89 E+01$ & & & & & & & & & & & & & & & 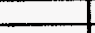 & & & 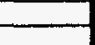 \\
\hline$\frac{\text { Resin }}{\text { Votume }}$ & & & & 023 & 1.23 & 0.38 & $0.3 !$ & 1.4 & 0.9 & 1.4 & $\begin{array}{r}0.030 \\
0.0000284\end{array}$ & 0.040 & & & & 1.039 & & & 0.024 \\
\hline Total Mass.kg & 401.5 & 2.5 & 3990 & 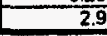 & 396.1 & 8.2 & 2.99 & 392.6 & 0.3 & 392.6 & 0.0 & 21.0 & & 464.5 & 1614.4 & 2078.9 & 41.6 & 55 & \\
\hline
\end{tabular}





\subsection{Conclusion}

Conceptual process flow diagrams and mass balances have been developed and described in this study for many SNF, calcine, and liquid waste disposal alternatives. The options include both direct disposal of the waste material and separation of radioactive components from the inert materials. Separations alternatives introduce aqueous and pyrochemical techniques.

All of the alternatives require some level of developmental effort before they could be successfully implemented. Some technologies are much less mature than others. For example, the pyrochemical processing of SNF is still at the laboratory proof-of-principle stage, while utilization of solvent extraction technology for component recovery is well demonstrated at full scale in a radioactive environment.

Each of the waste disposal alternatives has specific advantages and disadvantages. Evaluation of the options against specific criteria, such as final immobilized waste volumes, life-cycle costs, ability to meet time frames, safety risk, and technical risk are beyond the scope of this study. However, the information presented in this document provides the technical basis for performing such an evaluation. 